Prepared in cooperation with the Broward County Environmental Planning and Community Resilience Division

\title{
Potential Effects of Alterations to the Hydrologic System on the Distribution of Salinity in the Biscayne Aquifer in Broward County, Florida
}

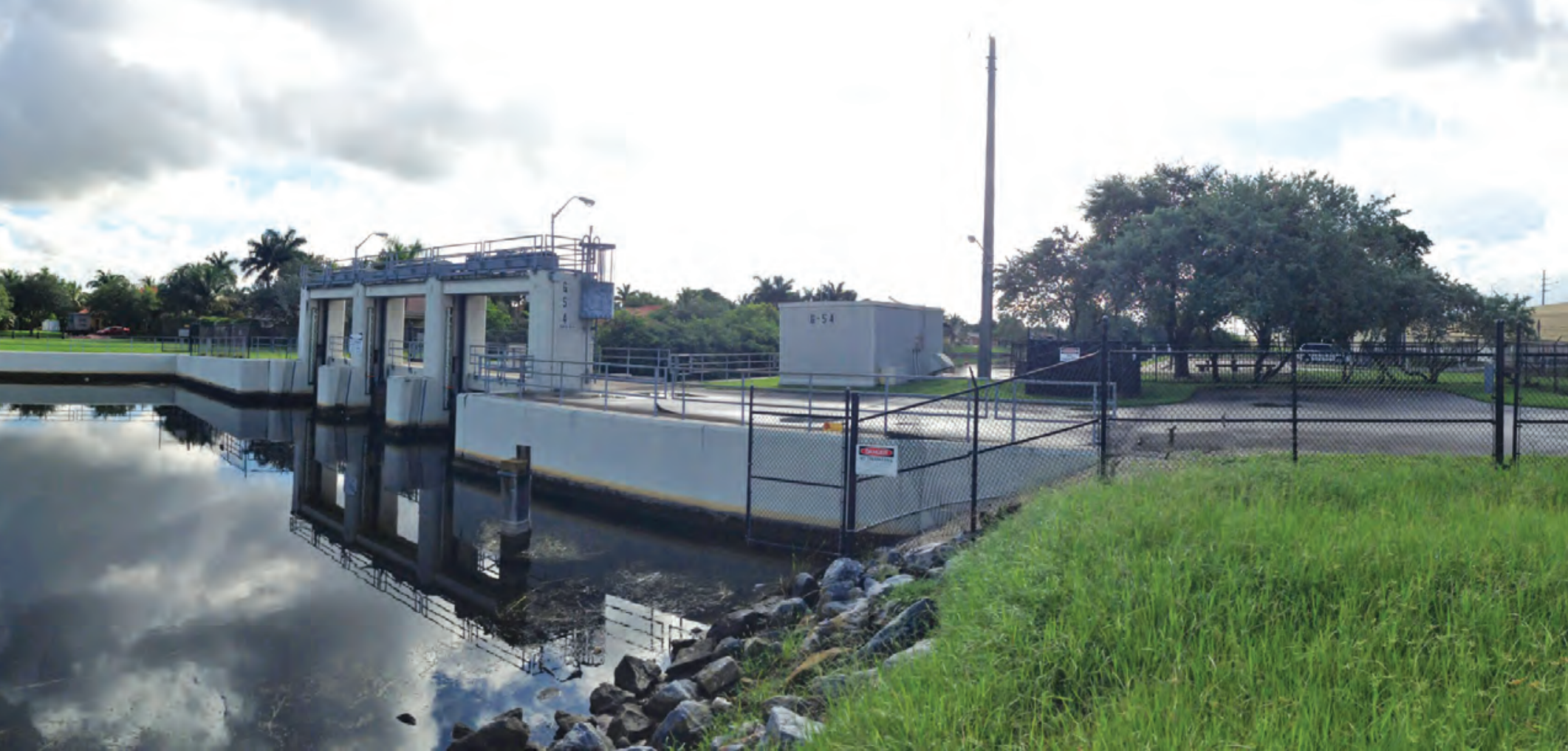

Scientific Investigations Report 2016-5022 
Cover. Surface-water and salinity control stucture G-54, on the North New River Canal, Broward County, Florida (photograph by Joseph D. Hughes, U.S. Geological Survey). 


\section{Potential Effects of Alterations to the Hydrologic System on the Distribution of Salinity in the Biscayne Aquifer in Broward County, Florida}

By Joseph D. Hughes, Dorothy F. Sifuentes, and Jeremy T. White

Prepared in cooperation with the Broward County Environmental Planning and Community Resilience Division

Scientific Investigations Report 2016-5022 


\section{U.S. Department of the Interior SALLY JEWELL, Secretary}

\section{U.S. Geological Survey Suzette M. Kimball, Director}

\section{U.S. Geological Survey, Reston, Virginia: 2016}

For more information on the USGS - the Federal source for science about the Earth, its natural and living resources, natural hazards, and the environment—visit http://www.usgs.gov or call 1-888-ASK-USGS.

For an overview of USGS information products, including maps, imagery, and publications, visit http://www.usgs.gov/pubprod/.

Any use of trade, firm, or product names is for descriptive purposes only and does not imply endorsement by the U.S. Government.

Although this information product, for the most part, is in the public domain, it also may contain copyrighted materials as noted in the text. Permission to reproduce copyrighted items must be secured from the copyright owner.

\section{Suggested citation:}

Hughes, J.D., Sifuentes, D.F., and White, J.T., 2016, Potential effects of alterations to the hydrologic system on the distribution of salinity in the Biscayne aquifer in Broward County, Florida: U.S. Geological Survey Scientific Investigations Report 2016-5022, 114 p., http://dx.doi.org/10.3133/sir20165022.

ISSN 2328-0328 (online) 


\section{Contents}

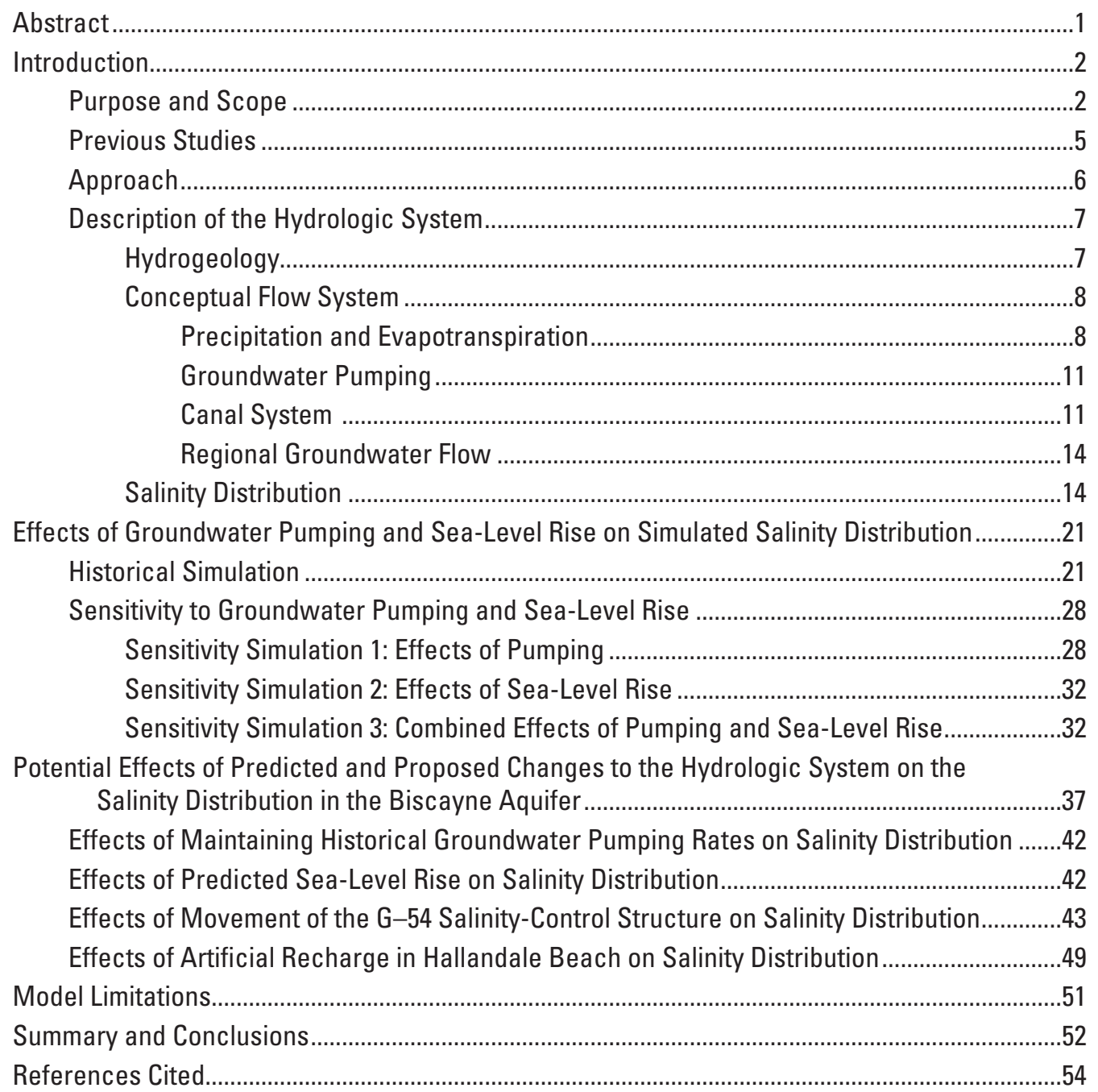


Appendix 1. Model Construction and Calibration ........................................................................57

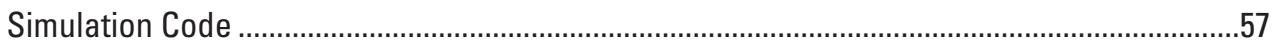

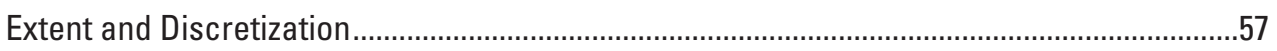

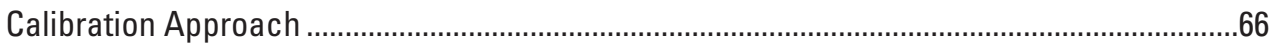

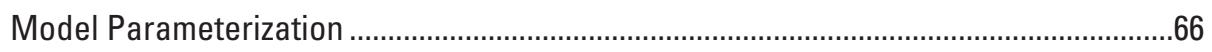

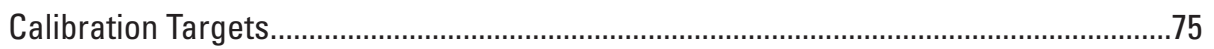

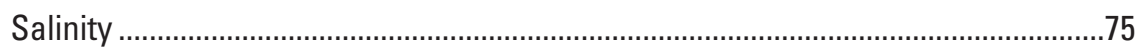

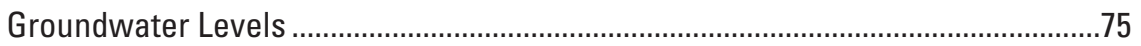

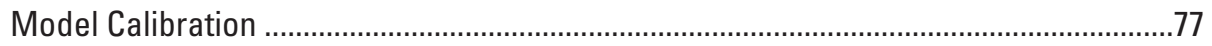

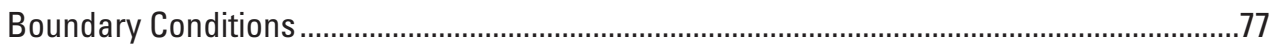

Specified Heads and Fluxes...............................................................................

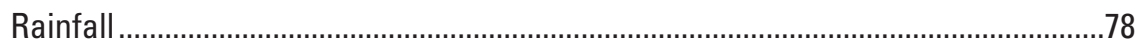

Groundwater Pumping .......................................................................................

Head-Dependent Boundaries ............................................................................... 80

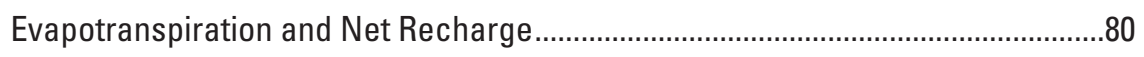

Intracoastal Waterway and Tidal Finger Canals ....................................................

Non-Tidal Surface-Water Canals...........................................................................

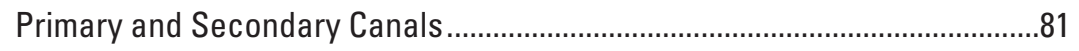

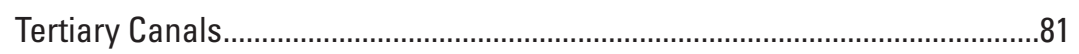

Groundwater Flow Across the Northern and Southern Edge of the Model ...........84

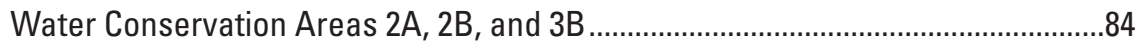

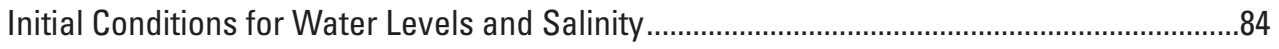

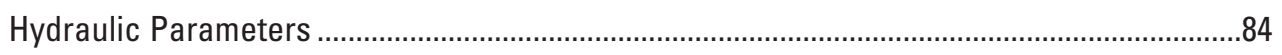

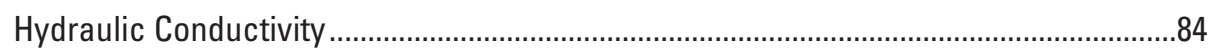

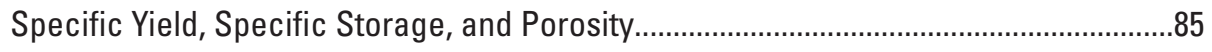

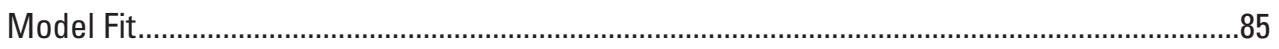

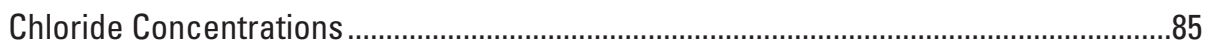

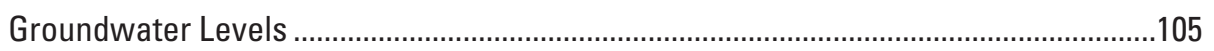

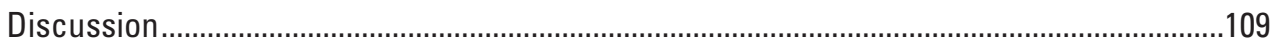

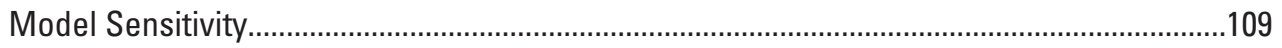

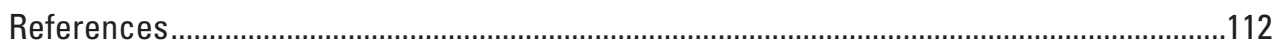




\section{Figures}

1. Map of the study area in southeastern Florida ..................................................................

2. Block diagram showing conceptual model of groundwater flow and saltwater transport in the Biscayne aquifer, Broward County .............................................

3. Graph showing local tidal stage composited from the Miami Beach, Haulover Pier, and Virginia Key National Oceanic and Atmospheric Administration tidal stations, 1950-2012.

4. Graph showing population and groundwater use in Broward County, Florida, 1945-2030

5. Schematic hydrogeologic cross section of Broward County ….........................................

6. Hydrostratigraphic and model layer correlation chart for the surficial aquifer system in Broward County

7. Graphs showing estimated average annual precipitation and average reference evapotranspiration rates in Broward County, 1950 to 2011 ............................................10

8. Graph showing monthly public-supply groundwater pumping in simulated area ..........11

9. Map showing locations and decadal construction periods of production wells or abandoned wells in the study area.

10. Map showing primary and secondary canals in study area and period of construction

11. Map showing freshwater-saltwater interfaces in the Biscayne aquifer in Broward County, 1945, 1969, 1972, 1996, and 2009; locations of salinity data used to calibrate the model, and induction log data; and well-field areas.

12. Electromagnetic induction logs at G-2903 in Hallandale Beach, 2000-11

13. Electromagnetic induction logs and chloride concentration and water level at G-2896 in Pompano Beach, 2000-11

14. Graph showing salinity concentrations versus time for all calibration wells in study area, at G-2426 in Hollywood, and at G-2900 in Davie

15. Graph showing electromagnetic induction logs at G-2900 in Davie, 2000-11 ...............19

16. Graph showing electromagnetic induction logs at G-2921 in Davie, 2000-11 ...............20

17. Map showing simulated distribution of salinity at the base of the Biscayne aquifer at the end of 2011

18. Map showing locations of cross sections and cross sections of simulated salinity distribution at the end of 2011.

19. Map showing locations of cross sections and cross sections of simulated salinity distribution at the end of 2011.

20. Map showing simulated 10,000-milligram-per-liter isochlors at the end of 1970, 1980, 1990, 2000, 2005, and 2011

21. Map showing difference in simulated groundwater levels in 2011 at the base of the Biscayne aquifer between Sensitivity Simulation 1 and the historical simulation...........30

22. Map showing simulated extent of the 1,000-milligram-per-liter isochlor in 2011 at the base of the Biscayne aquifer for Sensitivity Simulation 1 and the historical simulation

23. Map showing difference in simulated groundwater levels in 2011 at the base of the Biscayne aquifer between Sensitivity Simulation 2 and the historical simulation.

24. Map showing simulated extent of the 1,000-milligram-per-liter isochlor in 2011 at the base of the Biscayne aquifer for Sensitivity Simulation 2 and the historical simulation 
25. Map showing difference in simulated groundwater levels in 2011 at the base of the Biscayne aquifer between Sensitivity Simulation 3 and the historical simulation

26. Map showing simulated extent of the 1,000-milligram-per-liter isochlor in 2011 at the base of the Biscayne aquifer for Sensitivity Simulation 3 and the historical simulation

27. Graphs showing deviations from mean annual rainfall during 1950-2011 and mean annual rainfall during 1981-2011.

28. Graphs showing predicted tide, weather component of tide, and synthetic tide generated for Base Case Scenario.

29. Map showing simulated extent of the 1,000-milligram-per-liter isochlors during 2011 at the end of the historical simulation, and during 2060 for the Base Case Scenario and Scenario 1 .

30. Graphs showing simulated, flow-weighted, average chloride concentration at select well fields for the Base Case Scenario and Scenario 1

31. Graphs showing average monthly pumping during 2007-11, and monthly pumping distribution for Scenario 1

32. Graph showing monthly sea-level elevations applied to the scenarios

33. Map showing simulated extent of the 1,000-milligram-per-liter isochlors for the Base Case, and Scenarios 2, 3, and 4 during 2060

34. Simulated, flow-weighted, average chloride concentrations at select well fields

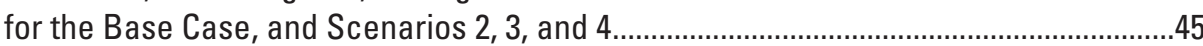

35. Map showing current and proposed location of the G-54 salinity-control structure.........46

36. Map showing simulated extent of the 1,000-milligram-per-liter isochlors for the Base Case, and Scenarios 4 and 5 during 2060

37. Graphs showing simulated, flow-weighted, average chloride concentration at select well fields for the Base Case Scenario, and Scenarios 4 and 5

38. Map showing simulated extent of the 1,000-milligram-per-liter isochlors for the Base Case Scenario, and Scenarios 4 and 6 during 2060

39. Cross sections of simulated salinity distribution in the Hallandale Beach area after 1, 10, 20, 30, 40, and 50 years simulated time for Scenario 6 .

40. Graphs showing simulated, flow-weighted, average chloride concentration at select well fields for the Base Case, and Scenarios 4 and 6 .....

1-1. Map showing surface-water basins, canals, and surface-water control structures, and groundwater boundary conditions for layer 1 in the flow model area.

1-2. Map showing model grid resolution shown in a part of the active groundwater model domain

1-3. Map showing gridded land-surface elevations in the active part of the model.

1-4. Map showing top of 03-unit (layer 2), which corresponds to the bottom of layer 1 (Miami Limestone) in the active part of the model.

1-5. Maps showing top of the 02-unit (layer 3), top of the 01-unit (layer 7), and top of the Pinecrest Sand Member of the Tamiami Formation (layer 11), in the active part of the model

1-6. Maps showing top (layer 11), and B, base (layer 12) of the Ochopee Limestone Member of the Tamiami Formation, in the active part of the model 68

1-7. Maps showing thickness of the Biscayne aquifer production zone (layers 3 to 10) and the water-table aquifer (layers 1 to 12), in the active part of the model. .70 
1-8. Map showing location of Atlantic Coastal Ridge and Sandy Flatlands in the active part of the model . .72

1-9. Hydrogeologic sections $\mathrm{I}-\mathrm{I}^{\prime}$ through $\mathrm{K}-\mathrm{K}^{\prime}$ in the active part of the model ......................73

1-10. Map showing pilot points used to condition select groundwater properties adjusted during model calibration.

1-11. Map showing location of no-flow, specified head, and head-dependent groundwater boundary conditions

1-12. Map showing calibrated extinction depth for the period from 2010 through 2012 .........82

1-13. Map showing drainage elevations used in developed areas of Broward County to represent the effect of tertiary canals on water-table elevations

1-14. Maps showing calibrated horizontal and vertical hydraulic conductivity of the UPR unit..

1-15. Maps showing calibrated horizontal and vertical hydraulic conductivity of the PD1 unit

1-16. Maps showing calibrated horizontal and vertical hydraulic conductivity of the PD2 unit

1-17. Maps showing calibrated horizontal and vertical hydraulic conductivity of the LWR unit

1-18. Map showing calibrated specific yield for the UPR unit

1-19. Maps showing calibrated specific storage values for the UPR, PRD, and LWR units

1-20. Maps showing calibrated porosity values for the UPR, PD1, PD2, and LWR units .......100

1-21. Graphs showing simulated and observed chloride concentrations at the 11 observation locations

1-22. Graphs showing simulated and observed water levels at the 15 observation locations.

1-23. Map showing simulated water-table elevations at the end of 2011 in the active part of the model

1-24. Graphs showing composite parameter sensitivity of simulated groundwater levels, salinities at calibration points, and flow-weighted well-field chloride concentrations to parameter changes

\section{Tables}

1. Historical, sensitivity, and future scenario conditions ....................................................32

2. Pumping distributions by composite well field for 2007-11 and all scenarios ................37

1-1. Theoretical semivariogram models and parameters for Holocene and Pleistocene sediment sequences and Biscayne aquifer hydraulic conductivity....

1-2. Site information and type of data used for salinity and water-level calibration, and other sites

1-3. Calibrated monthly rainfall multipliers ...............................................................................

1-4. Calibrated extinction depth multipliers ................................................................... 81

1-5. Values and ranges of values of calibrated hydraulic properties, and hydraulic properties estimated from field data or laboratory samples 


\section{Conversion Factors}

Inch/Pound to International System of Units

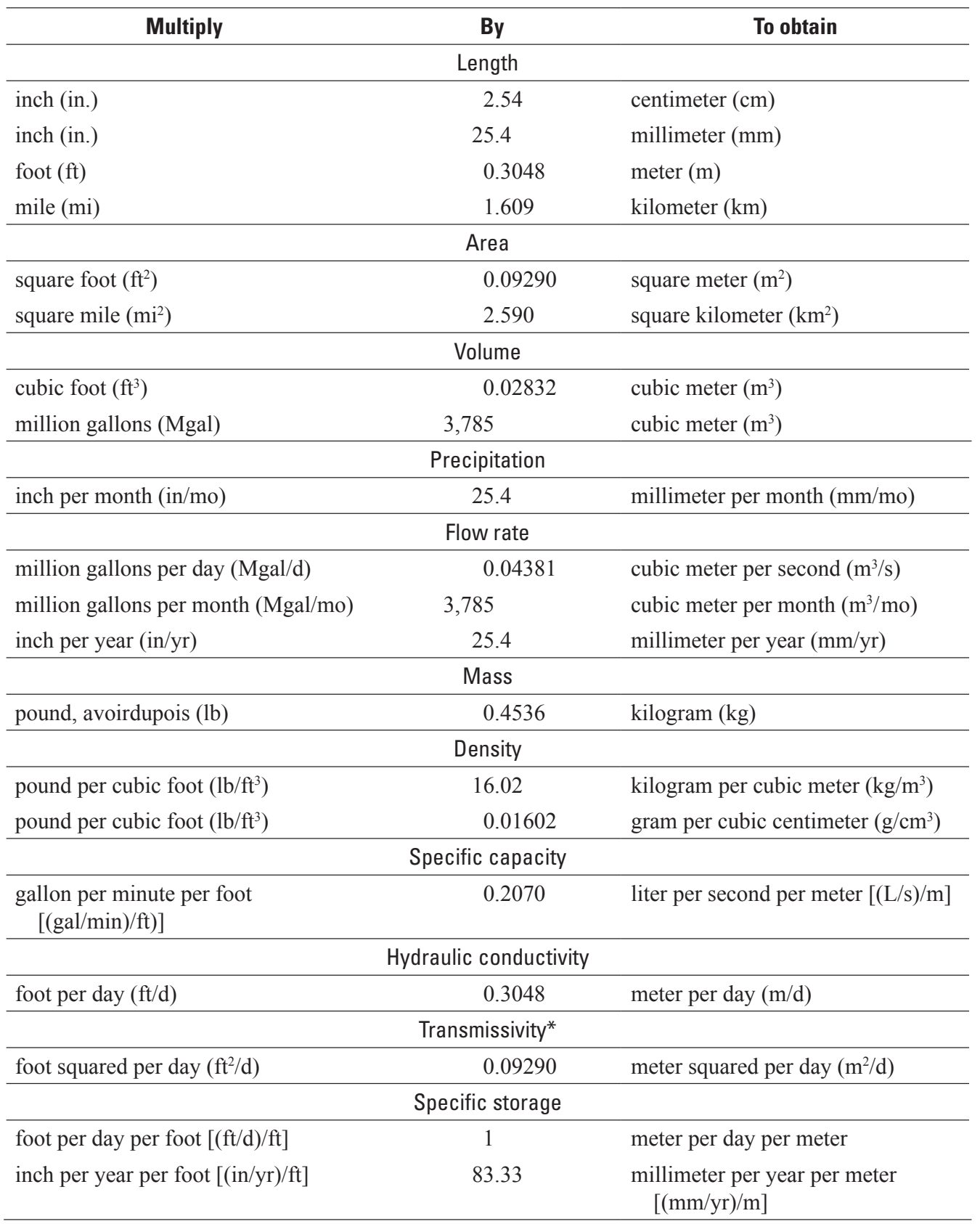

\section{Datums}

Vertical coordinate information is referenced to the North American Vertical Datum of 1988 (NAVD 88).

Horizontal coordinate information is referenced to the North American Datum of 1983 (NAD 83). Elevation, as used in this report, refers to distance above the vertical datum. 


\section{Supplemental Information}

Transmissivity: The standard unit for transmissivity is cubic foot per day per square foot times foot of aquifer thickness $\left[\left(\mathrm{ft}^{3} / \mathrm{d}\right) / \mathrm{ft}^{2}\right] \mathrm{ft}$. In this report, the mathematically reduced form, foot squared per day $\left(\mathrm{ft}^{2} / \mathrm{d}\right)$, is used for convenience.

Bulk conductivity is given in millisiemens per meter $(\mathrm{mS} / \mathrm{m})$.

Concentrations of chemical constituents in water are given in milligrams per liter (mg/L).

\section{Abbreviations}

$\begin{array}{ll}\text { APT } & \text { aquifer performance test } \\ \text { CERP } & \text { Comprehensive Everglades Restoration Plan } \\ \text { CHD } & \text { MODFLOW specified head package } \\ \text { DRN } & \text { MODFLOW drain package } \\ \text { EDEN } & \text { Everglades Depth Estimation Network } \\ \text { EPA } & \text { U.S. Environmental Protection Agency } \\ \text { ET } & \text { evapotranspiration } \\ \text { EVT } & \text { MODFLOW evapotranspiration package } \\ \text { EXDP } & \text { extinction depth } \\ \text { GHB } & \text { MODFLOW general head package } \\ \text { GOES } & \text { Geostationary Operational Environmental Satellite } \\ \text { LECSR } & \text { Lower East Coast sub-Regional Model } \\ \text { lidar } & \text { light detection and ranging } \\ \text { LWR } & \text { lower units } \\ \text { ME } & \text { mean error } \\ \text { NEXRAD } & \text { next generation radar } \\ \text { NOAA } & \text { National Oceanic and Atmospheric Administration } \\ \text { NRC } & \text { National Research Council } \\ \text { NWIS } & \text { National Water Information System } \\ \text { NWS } & \text { National Weather Service } \\ \text { PEST } & \text { parameter estimation software } \\ \text { PD1 } & \text { upper production unit } \\ \text { PD2 } & \text { lower production unit } \\ \text { PRD } & \text { production units } \\ \text { RCH } & \text { MODFLOW recharge package } \\ \text { RET } & \text { reference evapotranspiration } \\ \text { RIV } & \text { MODFLOW river package } \\ \text { RMSE } & \text { root mean square error } \\ \text { SFWMD } & \text { South Florida Water Management District } \\ \text { SURF } & \text { MODFLOW EVT surface package } \\ \text { TVD } & \text { total variation diminishing } \\ \text { UPR } & \text { upper units } \\ \text { USGS } & \text { U.S. Geological Survey } \\ \text { WEL } & \text { MODFLOW well package } \\ \text { WSI } & \text { Weather Services Incorporated } \\ & \end{array}$




\section{Acknowledgments}

The authors would like to thank several staff from the Broward County Environmental Planning and Resilience Division. Samantha Danchuk, Jennifer Jurado, Barbara Powell and Michael Zygnerski provided a thorough review of the report and insightful discussions, greatly improving the value of the report for water-resource managers; Katie Lelis helped compile spatial data for model input; and Mike Zygnerski, additionally, assisted in gathering data for model input, connected the authors with suppliers of municipal data, and provided timely, helpful responses to many questions. Jayantha Obeysekera and Angela Montoya of the South Florida Water Management District also provided valuable technical insight regarding model construction throughout the development of the model. The authors are grateful for the contributions of information and data by Broward County's cost share partners in this project, including City of Dania Beach, City of Fort Lauderdale, City of Hollywood, and City of Hallandale Beach.

The authors would also like to thank several U.S. Geological Survey (USGS) staff. Steve Phillips of the California Water Science Center and Jeff Raffensperger of the Maryland/Delaware/ District of Columbia Water Science Center provided thorough technical reviews, greatly improving technical discussions in the report. Scott Prinos of the Caribbean-Florida Water Science Center (CFWSC) and Kevin Defosset of Nova Southeastern University and the CFWSC provided and interpreted historical salinity and induction log data. Mike Turtora, retired, of the CFWSC constructed model scenario data sets. Amor Elder, formerly of the CFWSC, constructed evapotranspiration data sets. Mike Deacon of the Science Publishing Network (SPN) provided an outstanding and thorough editorial review. Kim Swidarski of the SPN created the beautiful figures. Finally, Caryl Wipperfurth, also of the SPN, provided advice in early consultations on map figures and created the final layout. 


\title{
Potential Effects of Alterations to the Hydrologic System on the Distribution of Salinity in the Biscayne Aquifer in Broward County, Florida
}

\author{
By Joseph D. Hughes, Dorothy F. Sifuentes, and Jeremy T. White
}

\begin{abstract}
To address concerns about the effects of water-resource management practices and rising sea level on saltwater intrusion, the U.S. Geological Survey in cooperation with the Broward County Environmental Planning and Community Resilience Division, initiated a study to examine causes of saltwater intrusion and predict the effects of future alterations to the hydrologic system on salinity distribution in eastern Broward County, Florida. A three-dimensional, variable-density solute-transport model was calibrated to conditions from 1970 to 2012, the period for which data are most complete and reliable, and was used to simulate historical conditions from 1950 to 2012. These types of models are typically difficult to calibrate by matching to observed groundwater salinities because of spatial variability in aquifer properties that are unknown, and natural and anthropogenic processes that are complex and unknown; therefore, the primary goal was to reproduce major trends and locally generalized distributions of salinity in the Biscayne aquifer. The methods used in this study are relatively new, and results will provide transferable techniques for protecting groundwater resources and maximizing groundwater availability in coastal areas. The model was used to (1) evaluate the sensitivity of the salinity distribution in groundwater to sea-level rise and groundwater pumping, and (2) simulate the potential effects of increases in pumping, variable rates of sea-level rise, movement of a salinity control structure, and use of drainage recharge wells on the future distribution of salinity in the aquifer.

Results from the simulation of historical conditions indicate that the model generally represents the observed greater westward extent of elevated salinity in the central part of the intruded area relative to the northern and southernmost parts of the intruded area. Results of sensitivity testing indicate
\end{abstract}

that the extent of elevated salinity is most sensitive to pumping in areas where the source of saltwater is largely offshore, from the Atlantic Ocean, and is most sensitive to sea-level rise in areas where the source of salinity is downward leakage of brackish water from canals.

Simulations of future scenarios indicate that increases in pumping near the existing interface may cause the interface to advance and decreases in pumping may cause it to retreat. Climatic effects, such as periods of prolonged drought or high precipitation, may augment or counteract long-term effects of changes in pumping on aquifer salinity at well fields. With increasing rates of sea-level rise, the freshwater-saltwater interface advances progressively inland, and flow-averaged salinities at well fields near the existing interface increase commensurately. Hypothetical southeastward (downstream) re-positioning of the existing G-54 salinity-control structure may prevent the interface from moving northwestward along and near the North New River canal, but beneficial effects are localized. Implementation of freshwater recharge wells in the city of Hallandale Beach may also have only a localized freshening effect in the aquifer and little appreciable effect on the freshwater-saltwater interface or on concentrations of salinity at well fields.

Model accuracy and use are limited by uncertainty in the physical properties and boundary conditions of the system, uncertainty in historical and future conditions, and generalizations made in the mathematical relationships used to describe the physical processes of groundwater flow and transport. Because of these limitations, model results should be considered in relative rather than absolute terms. Nonetheless, model results do provide useful information on the relative scale of response of the system to changes in pumping distribution, sea-level rise, and mitigation activities. 


\section{Introduction}

Saltwater intrusion of the Biscayne aquifer in Broward County, Florida (fig. 1), is a challenge for water-supply management. This issue is expected to persist, given current predictions of climate change, sea-level rise, and continued population growth. The Biscayne aquifer in Broward County is particularly susceptible to saltwater intrusion because of its high permeability, low hydraulic gradient, and proximity to an unlimited source of saltwater in the Atlantic Ocean. Additional factors that contribute to saltwater intrusion include groundwater pumping, rising sea level, anthropogenic alterations to the hydraulic system, and natural climatic variations.

The Biscayne aquifer is a shallow, unconfined to semiconfined aquifer composed of highly transmissive limestone situated on top of a large, flat carbonate platform that composes the Florida peninsula. In Broward County, estimated transmissivity values in the surficial aquifer system, of which the Biscayne aquifer is the most transmissive unit, are as high as 900,000 square feet per day $\left(\mathrm{ft}^{2} / \mathrm{d}\right.$; Fish, 1988). The groundwater and surface-water systems are closely connected, and the groundwater system reacts quickly and markedly to precipitation. Average annual precipitation between 1981 and 2010 was about 58 inches (in.), and generally ranged from about 2 inches per month (in/mo) in December to almost $9 \mathrm{in} / \mathrm{mo}$ in June. Land surface elevations are typically less than 20 feet (ft) in eastern Broward County (appendix fig. 1-3), and topographic relief is minimal. The Biscayne aquifer is in contact with the Atlantic Ocean offshore. The onshore potentiometric head gradient drives fresh groundwater toward the Atlantic, whereas differences in fluid density force the denser saltwater from the Atlantic Ocean into the deeper parts of the aquifer, beneath overlying freshwater-bearing parts of the aquifer (fig. 2).

The Biscayne aquifer is the primary source of water supply in Broward County, and groundwater withdrawals from the aquifer have steadily increased since the early 1900s. Groundwater extraction via pumping lowers groundwater levels in the aquifer, increasingly allowing saltwater to intrude the aquifer from the east. Groundwater pumping has been cited as a substantial cause of saltwater intrusion at several locations along the Atlantic coast (Lacombe and Carleton, 2002; Monti and others, 2009; Payne, 2010; Langevin and Zygnerski, 2013).

Rising sea level in the Atlantic Ocean reduces the eastward potentiometric gradient in the Biscayne aquifer, thereby elevating groundwater levels between the recharge areas and the coast. The reduced onshore potentiometric gradient allows saltwater to enter the aquifer more readily. Local mean sea level has risen approximately $0.5 \mathrm{ft}$ since 1950 (fig. 3). Numerous studies indicate that sea level in the North Atlantic has been rising for thousands of years; for example, Fairbanks (1989) indicates it has risen hundreds of feet in the past 18,000 years, and Kemp and others (2011) indicates it has risen nearly $10 \mathrm{ft}$ in the past 2,500 years.
The local hydrologic system has been substantially altered to allow urban development in southeastern Florida, including the eastern part of Broward County. An extensive network of canals has been constructed over decades to promote drainage and route excess water to the Atlantic Ocean during major precipitation events. Drainage tends to lower the water table and reduces the seaward movement of fresh groundwater. During the dry season (October to May), the canals are used to control saltwater intrusion by providing a source of freshwater that leaks into the Biscayne aquifer and maintains water-table elevations in the aquifer.

Broward County faces the possibility of increased saltwater intrusion. Population growth in the county is expected to continue, potentially increasing groundwater pumping (fig. 4), reducing groundwater levels, and increasing saltwater inflow to the aquifer. Sea-level rise has been predicted to continue, potentially reducing the eastward potentiometric gradient in the Biscayne aquifer and in tidal canals, and driving additional saltwater into the aquifer. In response to rising sea level, alterations to surface-water management are being considered to adapt to increased coastal flooding during major storm events. Such alterations are likely to affect salinity distribution in the aquifer, given the strong connection between the surface-water and groundwater systems. To address these concerns, the U.S. Geological Survey (USGS) in cooperation with the Broward County Environmental Planning and Community Resilience Division, initiated a study to examine causes of saltwater intrusion and predict the potential effects of future alterations to the hydrologic system on salinity distribution in eastern Broward County.

\section{Purpose and Scope}

The purpose of this report is to (1) evaluate controls on the salinity distribution from 1950 to 2012, and (2) to simulate potential effects of possible future alterations to the hydrologic system on salinity distribution in the Biscayne aquifer in the southern and central parts of eastern Broward County. The simulated area extends from the area just east of the Atlantic coastline to the area just west of the major canals separating the Everglades from the urbanized part of the county, and from the $\mathrm{C}-14$ basin in the north to the $\mathrm{C}-9$ east and west basins in the south (fig. 1). Historical and future hydrologic conditions affecting saltwater intrusion in the northeastern part of the county were studied previously (Langevin and Zygnerski, 2013). The study period represents the timeframe during which the greatest alterations to the hydrologic system were made and for which records are available to quantify the alterations. The study period also extends 50 years into the future, during which time proposed hypothetical changes to management of the hydrologic system might occur. Of particular interest are production well-field areas that potentially will be most affected by saltwater intrusion if current trends continue, including Dania, Dixie, Hallandale, and Hollywood well-field areas (fig. 1). The study results documented in this 


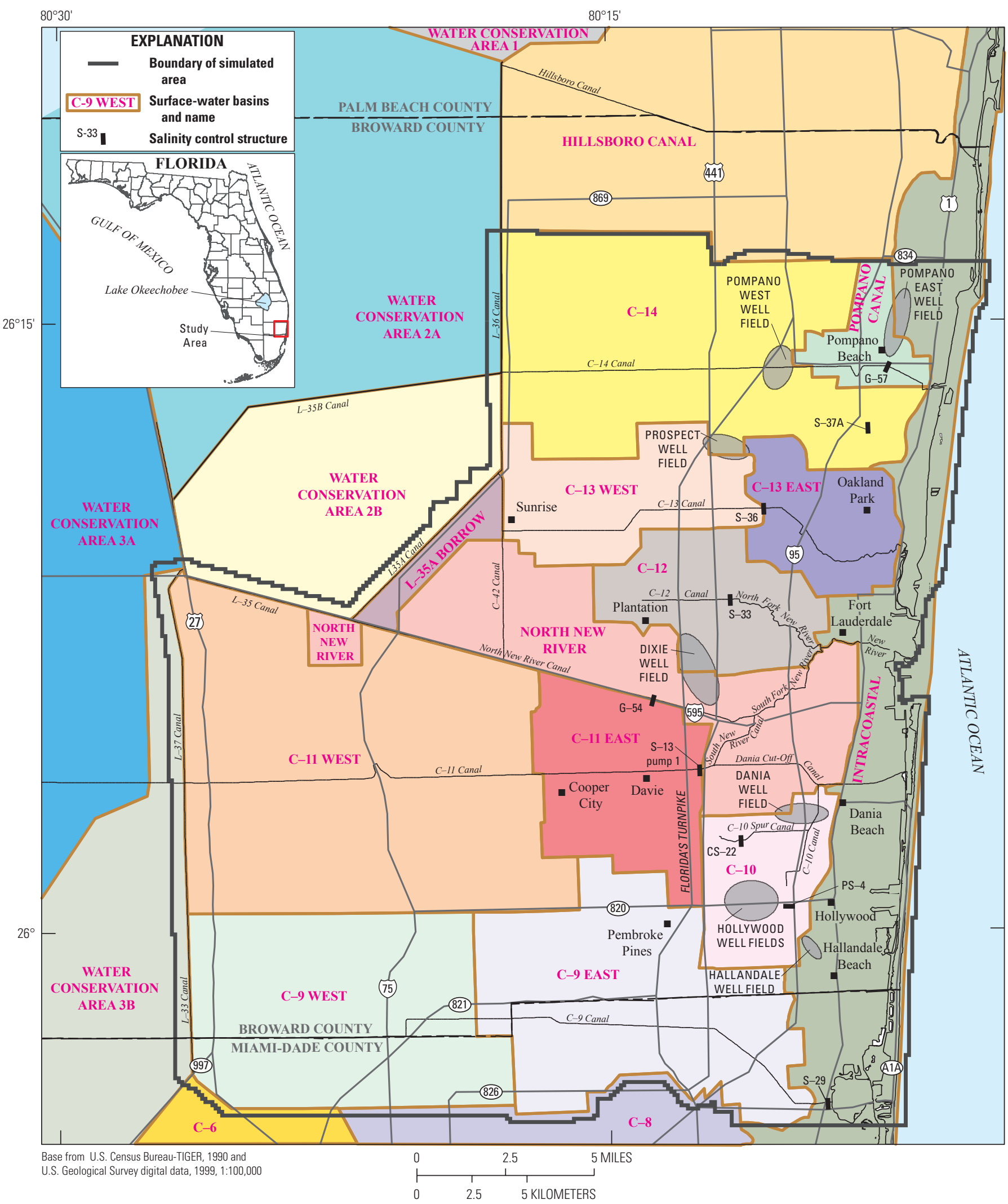

Figure 1. The study area in southeastern Florida. 


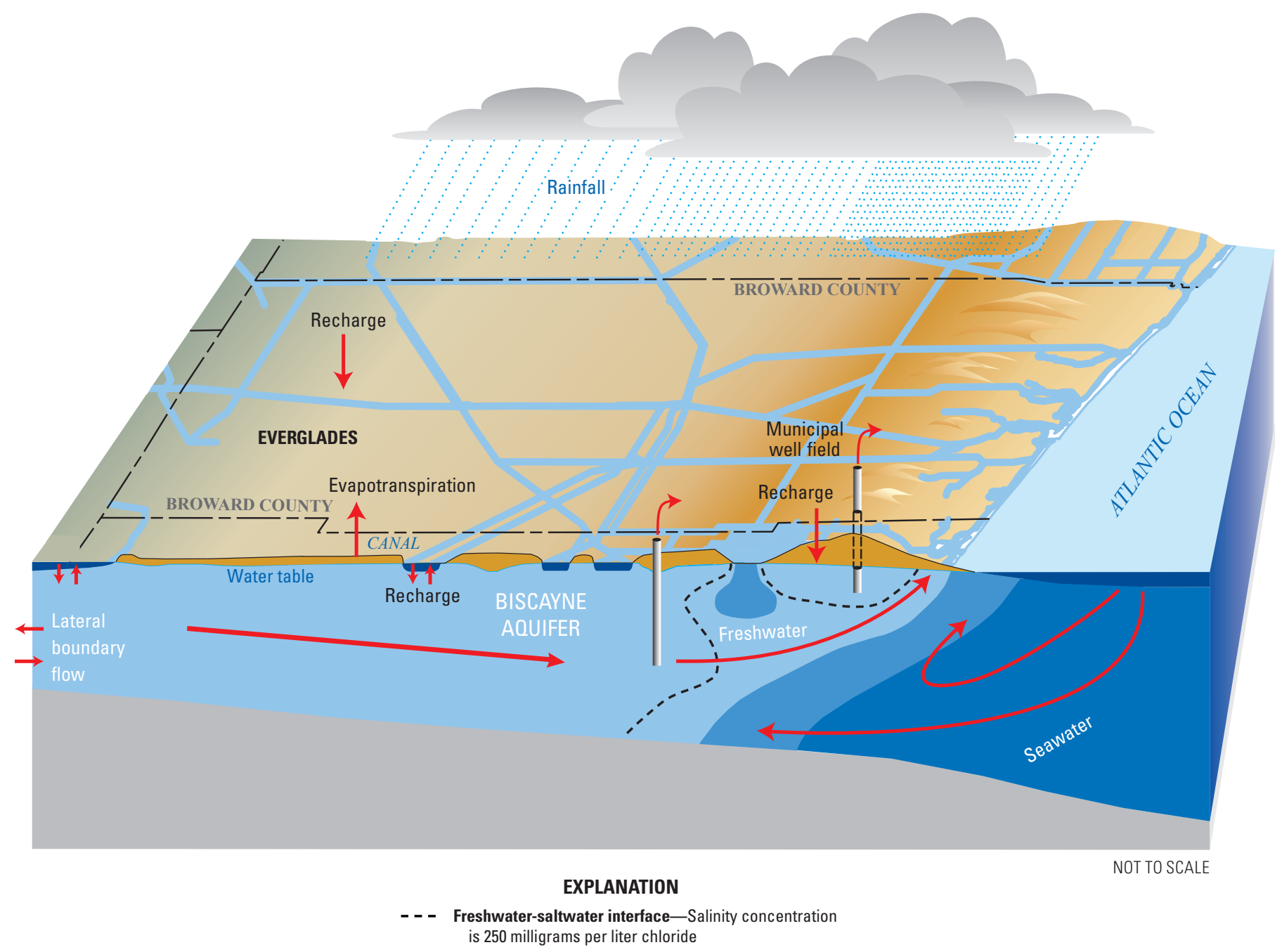

Figure 2. Conceptual model of groundwater flow and saltwater transport in the Biscayne aquifer, Broward County.

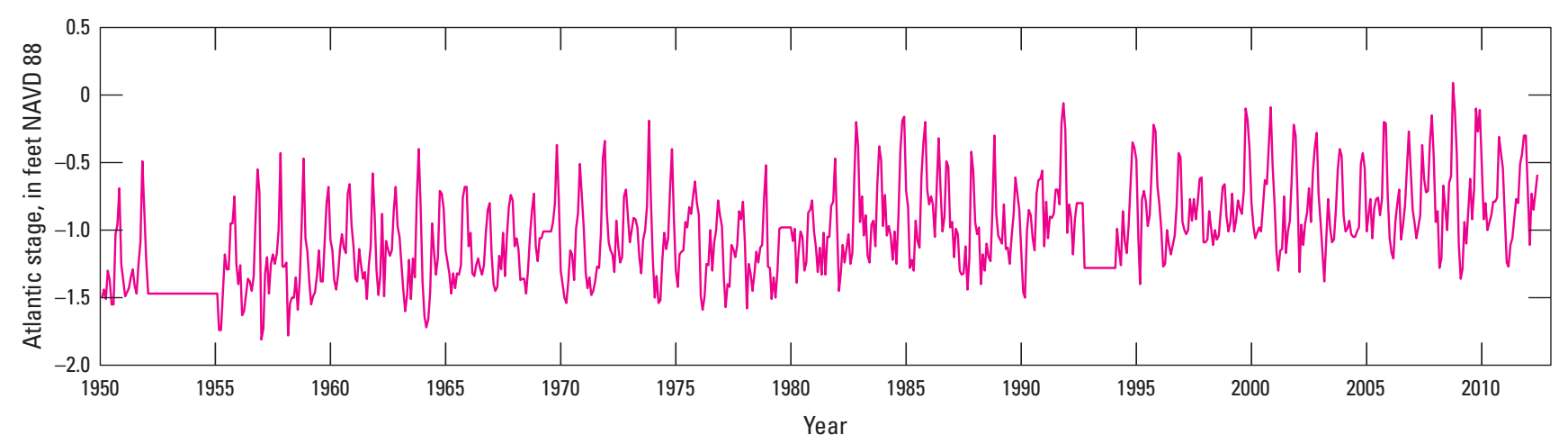

Figure 3. Local tidal stage composited from the Miami Beach, Haulover Pier, and Virginia Key National Oceanic and Atmospheric Administration tidal stations, 1950-2012. 


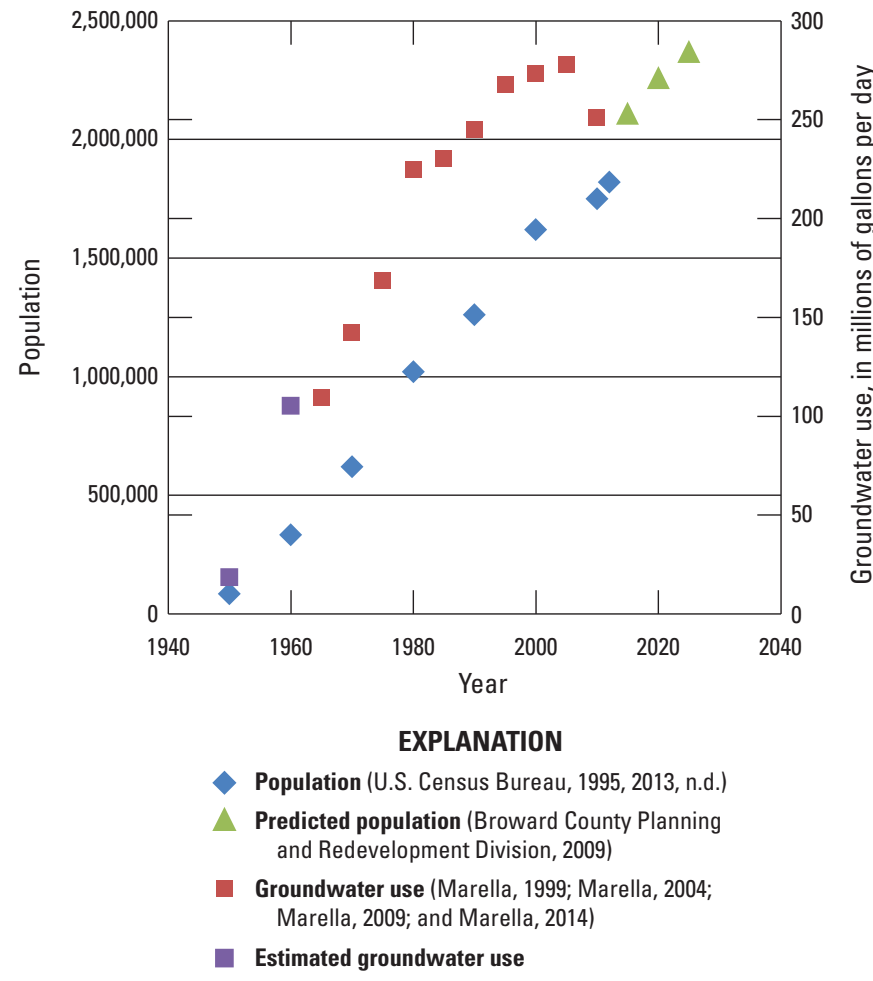

Figure 4. Population and groundwater use in Broward County, Florida, 1945-2030.

report augment findings from northeastern Broward County (Langevin and Zygnerski, 2013) to provide a comprehensive understanding of saltwater intrusion in the county.

This report documents the variable-density, groundwaterflow and solute-transport model, constructed using SEAWAT, to simulate saltwater movement in the Biscayne aquifer in the study area. The model is used to estimate the current distribution of salinity in the aquifer and simulate changes in salinity for a variety of hydrologic conditions. Included in the report are descriptions of the hydrologic system, including local hydrogeology of the Biscayne aquifer, the conceptual flow system, historical alterations to the hydrologic system, and the history of saltwater intrusion and current distribution of salinity in the aquifer. Details of model construction and calibration are presented in appendix 1. Model results are used to evaluate controlling factors for saltwater intrusion. Simulated changes in the salinity distribution as a result of hypothetical future conditions are presented, including sea-level rise, drought conditions, changes in groundwater pumping, movement of a surface-water control structure, and inclusion of recharge wells. Finally, limitations of the model and model results, and appropriate use of the model and model predictions are presented.

This report examines the influences of different mechanisms of saltwater intrusion, lateral intrusion from the ocean versus downward infiltration from coastal creeks and canals, on the distribution of salinity in the shallow aquifer. The relative effects of long-term sea-level rise, seasonal climatic variation, and multi-year climate trends on groundwater salinity are also presented. The methods used are relatively new, have not been applied in this type of hydrogeologic environment, and will provide useful guidance for the development of future models. Results from this study will provide transferable techniques for protecting groundwater resources and maximizing groundwater availability in coastal areas with large groundwater withdrawals and high surface-water/ groundwater interaction rates.

\section{Previous Studies}

The methods and analysis in this report draw largely on a previous study for which a variable-density, solute-transport model was developed for the northern part of coastal Broward County (Langevin and Zygnerski, 2013). With a focus on the Pompano well field, Langevin and Zygnerski (2013) evaluated the relative effects of historical well-field pumping and sea-level rise on the distribution of salinity in the Biscayne aquifer and estimated the effects of various rates of sea-level rise. The model developed by Langevin and Zygnerski (2013), a variable-density solute transport model constructed using SEAWAT version 4 (Langevin and others, 2007), was calibrated for 1900-2005 to groundwater level and salinity data from monitoring and production wells. The calibration period was chosen to be long enough to evaluate effects of historical sea-level rise, to be somewhat insensitive to errors resulting from poorly known initial salinity distribution, and to adequately represent observed temporal trends in salinity distribution. Langevin and Zygnerski (2013) used a dual transport domain approach in which salinity is transported at two different rates - more rapidly through discrete zones of large pore-space or fracture-enhanced permeability and more slowly through lower-permeability, widely distributed interstitial spaces within the rock matrix. The dual transport approach was used because of the observed presence of discrete zones of enhanced permeability in the Biscayne aquifer through which the bulk of saltwater transport likely occurs (Cunningham and others, 2006). In the dual domain transport approach, advective transport of saltwater dominates the higher-permeability, mobile domain of interconnected porosity, and diffusive transport of saltwater dominates the exchange between the mobile domain and the lowerpermeability, immobile domain, which contains unconnected pore spaces that contain relatively immobile fluids. The model was calibrated with parameter estimation software (PEST) (Doherty, 2010) using a highly parameterized automated inversion approach (Doherty and Hunt, 2010). Calibration parameters included spatially variable horizontal hydraulic conductivity, and uniform specific storage, specific yield, evapotranspiration extinction depth, irrigation recharge, dualdomain mass transfer rate, and immobile domain porosity. In addition, predevelopment salinity distribution was adjusted 
as a calibration parameter because of its uncertainty and its influence on simulated results during the study period. Results from this model of northeastern Broward County indicated that the salinity distribution is more sensitive, in general, to well-field pumping at historical rates than to sea-level rise or artificial recharge. If rates of sea-level rise increase in the future, they may result in an earlier arrival of elevated salinity at the Pompano well field.

Other groundwater flow and solute transport models have been developed to investigate the causes of, and management approaches to control, saltwater intrusion in Broward County. Andersen and others (1988) developed a set of groundwater flow and solute transport models, including a variable density transport model, to simulate the distribution and movement of salinity in the aquifer beneath the Hallandale Beach and test measures developed to restrict the movement of salinity for well-field management purposes. Although not calibrated, results of simulations using the well-field salinity transport model showed that the salinity distribution (1) is sensitive to long-term changes in groundwater levels; (2) tends to move toward a steady-state representative of average, long-term water-level conditions; and (3) is not particularly sensitive to shorter-term changes, such as seasonal cyclicity in water levels. The authors particularly noted the lag between groundwater-level declines and movement of the zone of elevated salinity, indicating that this lag could result in calibration difficulties. Moreover, the effects of management actions or other changes in the hydrologic system on the distribution of salinity may not become apparent for years or decades.

Merritt (1996) simulated the movement of the saltwater front or interface (zone of elevated groundwater salinity) in southern coastal Broward County to evaluate the hydrologic controls that most affect saltwater interface movement in the Biscayne aquifer. Two different types of models were used, a two-dimensional areal model that uses a sharp-interface method and a two-dimensional cross-section model that uses a variable-density method. Both models were not specifically calibrated to salinity data and both generally were not able to simulate the observed distributions in salinity. Instead, they were used to test model sensitivity to hydraulic conductivity, dispersion, hydrogeologic layering, localized pumping, and variations in recharge. Results obtained from the sharpinterface model showed that the position of the saltwater interface was moderately sensitive to recharge and relatively insensitive to the slope of the aquifer or the hydraulic conductivity. Results of the cross-sectional variable-density model showed that the transition zone thickness is sensitive to longitudinal dispersivity, moderately sensitive to the permeability distribution, and generally insensitive to recharge.

Dausman and Langevin (2005) developed a variabledensity groundwater-flow and solute-transport model based on a conceptual model representing an east-west section through the surficial aquifer system in Broward County to test the response of the freshwater-saltwater interface to various controls at different timescales. Results showed that
(1) short-term (less than 10-year) controls on saltwater interface movement differ as a function of proximity to canalsnear canals, the canal stage influences movement of the interface, and away from canals, recharge from precipitation has a predominant influence; and (2) the saltwater interface is more strongly controlled by vertical than horizontal groundwater flow. Over longer periods, results indicated that the saltwater interface is more strongly controlled by the upstream canal stage; elevated upstream stages may restrict inland movement of the interface.

Guha and Panday (2012) developed a three-dimensional variable-density solute-transport model of southern Broward and northern Miami-Dade Counties, extending west into the Everglades and water conservation areas, to predict the effects of sea-level rise on salinity distribution. The model was calibrated to groundwater levels, surface-water basin exchanges, and groundwater salinity measured over an 18-month dry period. This dataset was the basis against which sensitivity testing results of sea-level rise scenarios were compared. Sensitivity testing by manual perturbation showed that simulated salinity is sensitive to the dispersivity, hydraulic conductivity, and porosity values used. Simulated groundwater levels and salinity also were affected by variations in recharge and sea-level rise.

Other groundwater flow models have been developed for Broward County or include Broward County in their simulated areas. A groundwater flow model was developed for the surficial aquifer system in eastern Broward County using MODFLOW to address increasing water demands and evaluate potential changes by larger permit holders or applicants at the regional scale (Restrepo and others, 1992). Two other existing modeling studies provide extensive datasets used to construct the model documented in this report. The first, the Lower East Coast sub-Regional Model (LECSR) (Giddings and others, 2006), consists of a compilation of sub-regional groundwater flow models of the surficial aquifer system for the southeastern coast of Florida. The individual models that compose the LECSR were developed by the South Florida Water Management District (SFWMD) to assist with regional water supply plans, establishing minimum flows, engineering and operation plans, the Comprehensive Everglades Restoration Plan (CERP), and other projects (Giddings and others, 2006). The second modeling effort consists of groundwater and surface-water flow models developed for the urbanized part of Broward County using MIKE SHE and MIKE 11 programs (Islam and Dunn, 2006). These models were developed by Broward County to evaluate water management practices.

\section{Approach}

A variable-density solute-transport groundwater flow model was developed using SEAWAT and associated programs (appendix 1) to evaluate controls on the current and historical distribution of salinity in groundwater and simulate 
the potential effects of future alterations to the hydrologic system on salinity distribution in the Biscayne aquifer. This model accounts for both natural and anthropogenic hydrologic processes, including regional groundwater flow; groundwater pumping; recharge and discharge from surface-water bodies such as canals, lakes, the Atlantic Ocean; recharge from precipitation through porous land surface; evapotranspiration from flora, shallow soil and open water; and density-driven groundwater flow. This model represents historical and current conditions during 1950-2012 and was calibrated to groundwater level, surface-water basin flux, and salinity distribution during 1970-2012.

The model was used to evaluate the effects of groundwater pumping and sea-level rise on the current and historical distribution of salinity in groundwater. The model was then used to evaluate the potential effects of future increases of pumping to maximum permitted amounts, and a variety of hypothetical rates of sea-level rise during 2012-62. The model was also used to evaluate the potential effects of changes in management of the canal system by simulating future conditions with the G-54 structure moved eastward, and with use of drainage recharge wells. The resulting simulated changes in salinity distributions were compared to a Base Case Scenario, which accounts for no sea-level rise, current permitted pumping rates, and meteorological conditions prevailing during 1996-2011, which were drier than the 62-year (yr) average from 1950 to 2012 .

The model is designed to capture yearly to decadal trends in salinity distribution, rather than shorter-term trends. Models of saltwater intrusion are most effective at these long-term time scales because natural systems are so complex that accurately simulating small-scale complexities and short-term (for example, seasonal) changes in the salinity distribution at the county scale is difficult. In this case, salinity distribution is affected by a complex distribution and timing of groundwater pumping, highly variable recharge that can be affected by proximity to canals and by canal-structure operations, by major storm events, and a heterogeneous aquifer of very high permeability.

In general, solute-transport models are notoriously difficult to calibrate (Konikow, 2011). The mathematical representation is idealized and potentially introduces dispersion effects that are not generally observed in real systems (for example, upstream dispersion, irreversible dispersion, Gaussian distribution of solute spreading). The numerical solutions for the mathematical models are not ideal for handling both advective and dispersive solute movement and may introduce artificial movement of the solute, such as numerical dispersion, and solutions for reducing numerical dispersion may introduce overshooting or undershooting errors. Konikow (2011) explicitly demonstrates that different numerical algorithms for solving the mathematical model may produce different results. Finally, there is substantial uncertainty in the distribution of properties important in solute transport and their directional dependencies; for example, effective porosity, dispersivity, and hydraulic conductivity. Geologic heterogeneity strongly influences solute transport, and the distribution of any of these properties is usually unknown at scales necessary to accurately simulate transport movement. Even if the heterogeneity were well understood, the very small grid spacing and very short time steps needed to accurately simulate saltwater movement and salinity distribution are impractical. Konikow (2011) concludes, "... we should not expect that the calculated concentrations will accurately match all variations observed in the field, or even in a single observation well. Rather, one should aim to reproduce major trends and locally averaged values."

Although there are limitations in the temporal and spatial scales at which these types of models can accurately represent field conditions, they allow analysis of the effects of multiple coupled processes within a complex system, using the best available knowledge of the surface-water and groundwater systems. Despite their limitations, these types of tools can illustrate the relative importance of hydrologic controls, such as pumping, surface-water control structure operation and other management practices, and sea-level rise, on the movement of the saltwater interface and can be used to help manage the freshwater resources. Furthermore, results can be used to identify types of data that would help agencies better understand and manage the system, and the areas in which the data would be most beneficial.

\section{Description of the Hydrologic System}

The distribution and movement of salinity in the Biscayne aquifer in Broward County is a function of the hydrogeology, natural and man-made sources and sinks of groundwater, and the presence of a vast reservoir of saltwater in the adjacent Atlantic Ocean. The high permeability of the Biscayne aquifer, high seasonal precipitation and evapotranspiration (ET) rates, and low-relief topography create naturally low, eastward, lateral hydraulic gradients. Canals and production wells have accentuated and localized recharge and discharge processes since development of the area, while groundwater levels have generally declined in the Biscayne aquifer on the landward side of the freshwater-saltwater interface. Saltwater is transported upstream in canals to surface-water salinity-control structures by tidal fluctuations or during storms. Local sea level has been rising over the period of record, increasing the landward movement of saline groundwater.

\section{Hydrogeology}

The Biscayne aquifer is the most pervasive and productive aquifer within the surficial aquifer system in southeastern Florida. In Broward County, the Biscayne aquifer is largely composed of interbedded and interfingered units of limestone, sandstone, and unconsolidated sands, ranging in age from Pliocene to Holocene, and is delineated based on the presence 
Potential Effects of Alterations to the Hydrologic System on the Distribution of Salinity in the Biscayne Aquifer

of contiguous zones of elevated permeability (Fish, 1988). Geologic units that correspond to the Biscayne aquifer in Broward County include the Fort Thompson Formation in the western and central parts of the county, the Anastasia Formation, the Key Largo Limestone, and the Miami Limestone in the eastern part of the county (figs. 5, 6), and possibly the uppermost part of the Tamiami Formation (in some areas, depending on extent and permeability) (Fish, 1988; Reese and Cunningham, 2000).

The Biscayne aquifer in Broward County is unconfined to semiconfined and is designated by the U.S. Environmental Protection Agency (EPA) as a sole source aquifer (U.S. Environmental Protection Agency, 2013). The aquifer is greater than $300 \mathrm{ft}$ thick along the coast from the city of Hollywood north to the city of Pompano Beach, thins toward the west, and is not present in the western part of the county beneath the Everglades (Fish, 1988). The permeability of the aquifer is reflected in hydraulic conductivity values estimated from field tests, which range from about 1,000 to 78,000 feet per day (ft/d), and in transmissivity values, which have been estimated to be as high as $860,000 \mathrm{ft}^{2} / \mathrm{d}$ (Fish, 1988). The composition of the aquifer material largely determines the permeability of the aquifer, which increases with the ratio of porous limestone to clastic material or dense, low-porosity limestone. The amount of porous limestone relative to clastic material is higher in the eastern part of the study area than in the western part, but the amount of clastic material relative to limestone increases from south to north.

Geologic units of Pleistocene age that compose the Biscayne aquifer have been distinguished by Perkins (1977) on the basis of depositional sequences and environments and delineated by surfaces that represent depositional discontinuities. The study identified five Pleistocene geologic units, informally named from oldest to youngest as Q1, Q2, Q3, Q4, and Q5 (fig. 6). Each of these units represents a eustatic sea-level high stand and is composed of a distinct distribution of lithologic and depositional features, representative of specific marine depositional environments, of variable proximity to topographic features that define the depositional environment and provide sediment source material. The deepest units, Q1 and Q2, have similar lithologic features, tending to be composed of siliciclastic sediments and shell fragments, and are generally interpreted as representative of an inner shelf depositional environment. Lithologies in the Q3 unit indicate coral reef development, with a larger proportion of carbonate to siliciclastic lithologic components relative to Q1 and Q2. The upper surface of the Q3 unit is pronounced, and lithologies of the Q4 and Q5 units indicate a general reduction of sediment influx, containing finergrained carbonate and siliciclastic lithologies than Q3. The depositional environments of Q4 and Q5 are interpreted as shoals, barrier beaches, lagoons, and tidal bars. The surfaces of the Q units have features indicative of sub-aerial exposure. Perkins (1977) mapped these units across southern Florida, including Broward County.
Although a similar analysis has not been performed for the Biscayne aquifer in Broward County, in the geologic units composing the Biscayne aquifer in Miami-Dade County, depositional cycles exhibit predictable lithofacies patterns, and these lithofacies were found to correlate in a predictable way to porosity and permeability distribution, and thus flow distribution within the aquifer (Cunningham and others, 2006). The high-frequency cycles identified in Cunningham and others (2006) are the building blocks for, and are correlated with, the Q units as defined by Perkins (1977). In Miami-Dade County, the presence of a pore class characterized by high permeability and conduit flow is correlated generally with the Q1 unit; the Q2 unit tends to correlate with a pore class characterized by diffuse flow and moderate permeability; the upper part of Q3 and Q4 units tend to correlate with a pore class characterized by leaky, low permeability; and the Q5 unit tends to correlate with a pore class characterized by high permeability and conduit flow features. In Broward County, it is unclear how the permeability distribution correlates to depositional cycles. Furthermore, lithologic characteristics of the geologic units composing the Biscayne aquifer vary across Broward County. Thus, it is likely that a similar analysis relating porosity and permeability to depositional cycles in Broward County would provide different results.

\section{Conceptual Flow System}

Freshwater enters the shallow groundwater system in Broward County by means of direct recharge from precipitation, recharge from canals, recharge from surface water in the Everglades, and regional groundwater flow (fig. 2). Saltwater also enters the groundwater system through submarine recharge beneath the Atlantic Ocean, and coastal inlets, canals, and estuaries, which are brackish or periodically inundated with seawater. Water is removed from the shallow groundwater system through production well pumping, discharge to canals, ET, regional groundwater flow, and submarine groundwater discharge.

\section{Precipitation and Evapotranspiration}

During the study period, annual rainfall varied from about 37 to $107 \mathrm{in} / \mathrm{yr}$, with an average of $62 \mathrm{in} / \mathrm{yr}$ (fig. 7), based on next generation radar (NEXRAD) (Skinner and others, 2009) and SFWMD rain gage data collected since 1996 (South Florida Water Management District, n.d.), and interpolated National Oceanic and Atmospheric Administration (NOAA) rainfall data collected before 1996 (South Florida Water Management District, 2012) (appendix 1). Between 1995 and 2012, estimated reference evapotranspiration (RET) ranged from about 52 to $62 \mathrm{in} / \mathrm{yr}$, with an average of about $57 \mathrm{in} / \mathrm{yr}$ (fig. 7). The RET estimates are based on area-weighted, monthly, Geostationary Operational Environmental Satellite (GOES)-based RET data developed by Jacobs and others (2008); these data are discussed in more detail in appendix 1 . 
Western edge

Eastern edge

of study area

of study area

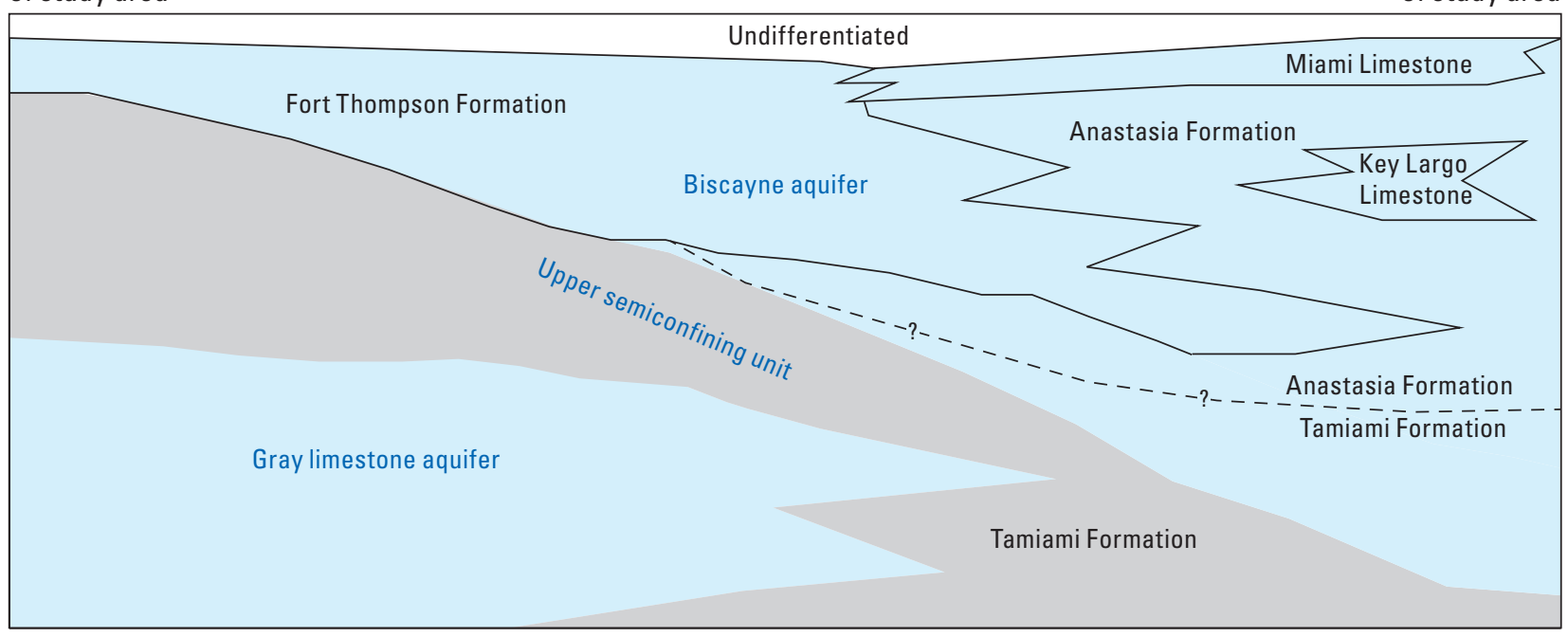

NOT TO SCALE

EXPLANATION

Lithostratigraphic boundary - - ? - - Location of base of Biscayne

aquifer uncertain

Figure 5. Schematic hydrogeologic cross section of Broward County (modified from Fish, 1988, and Reese and Cunningham, 2000).

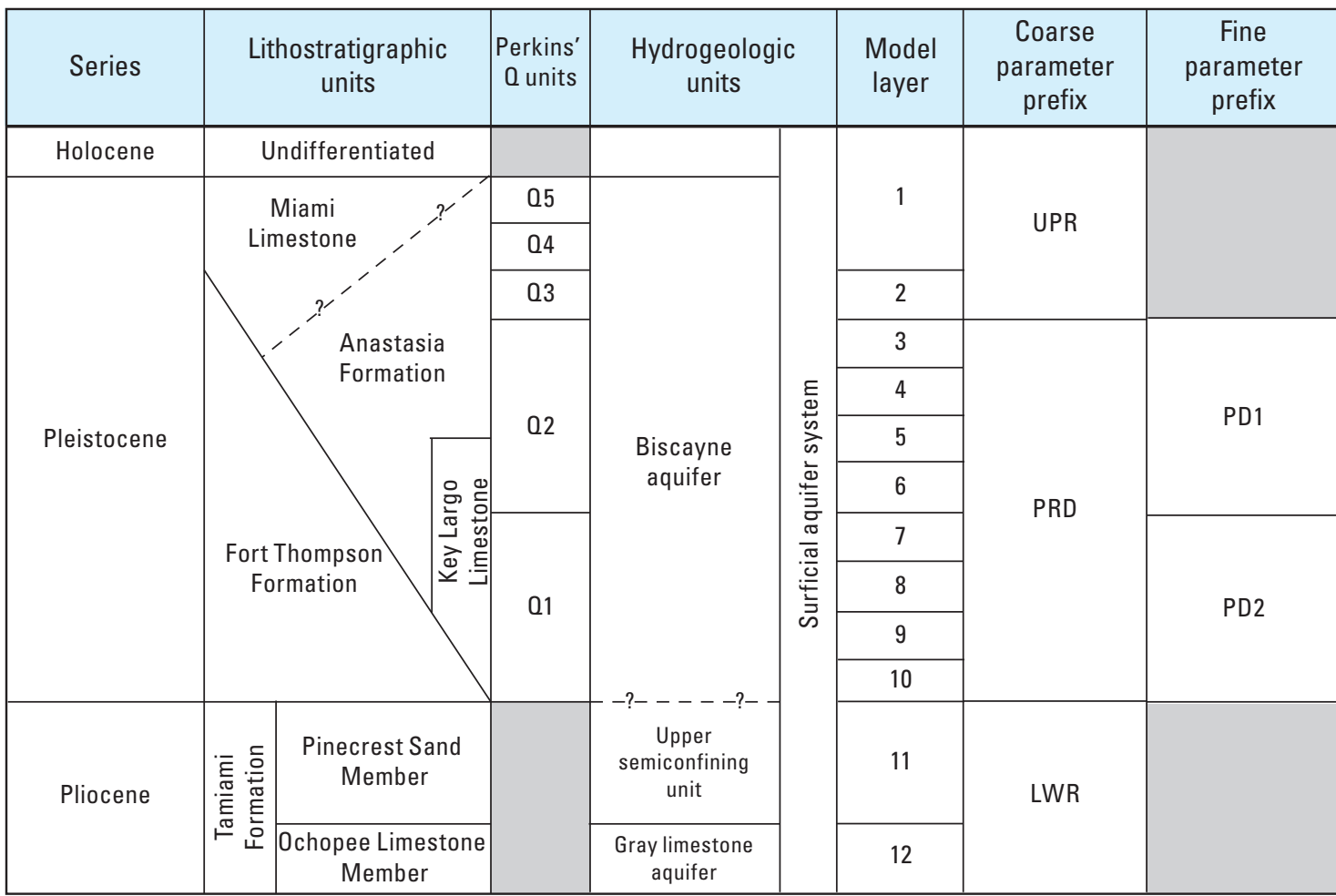

EXPLANATION

$\begin{array}{clcl}\text { UPR } & \text { Upper unit } & \text { PD1 } & \text { Upper production unit } \\ \text { PRD } & \text { Production units } & \text { PD2 } & \text { Lower production unit } \\ \text { LWR } & \text { Lower unit } & -?-?- & \begin{array}{c}\text { Uncertain lithostratigraphic } \\ \text { or hydrogeologic boundary }\end{array}\end{array}$

Figure 6. Hydrostratigraphic and model layer correlation chart for the surficial aquifer system in Broward County (Fish, 1988; Perkins, 1977; Reese and Cunningham, 2000). 

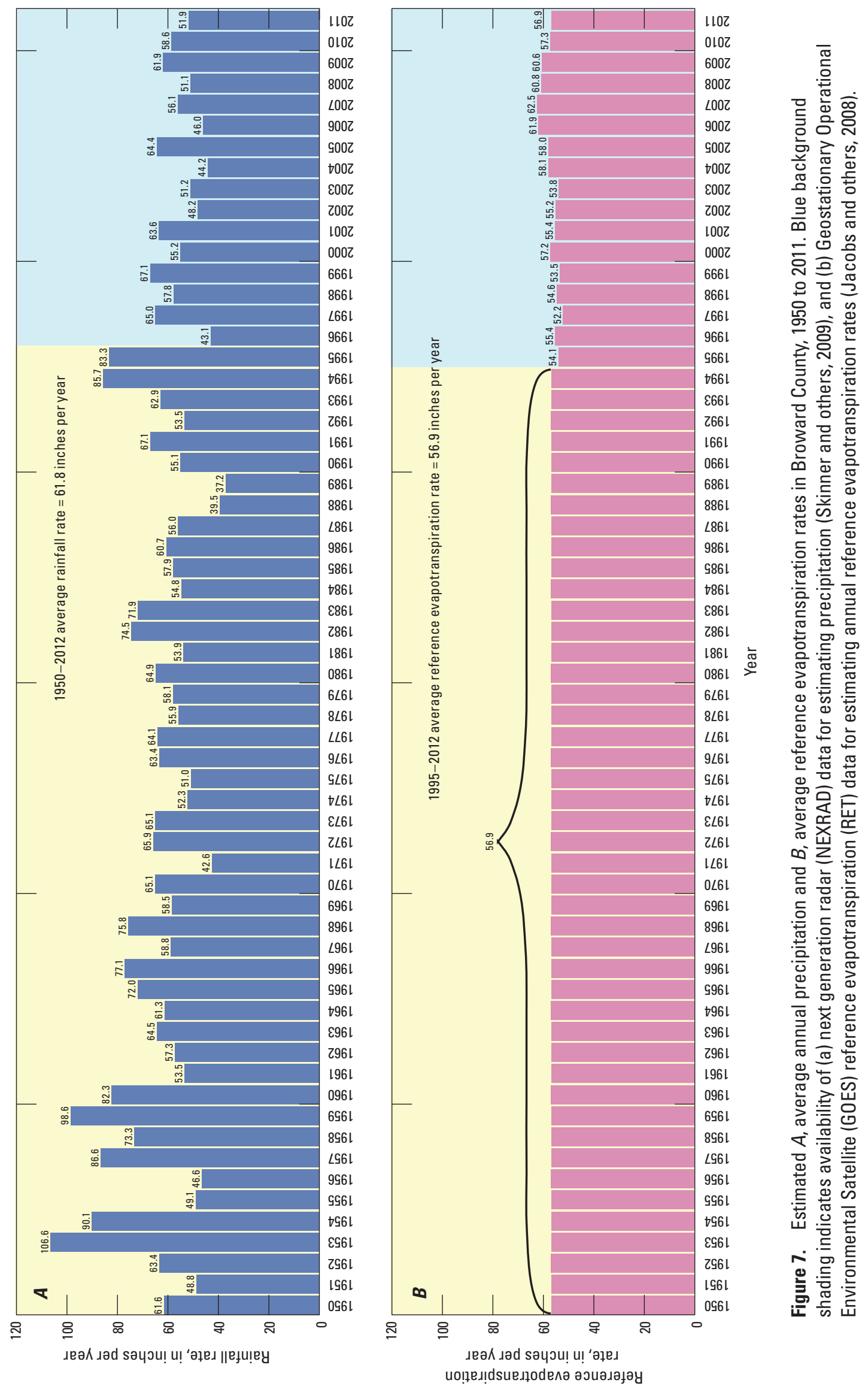


\section{Groundwater Pumping}

Historically, Broward County has relied on groundwater, withdrawn predominantly from the Biscayne aquifer, for most of its water-supply needs. Although groundwater has generally been withdrawn in increasing amounts since the inception of settlement of non-native communities in the late 19th to early 20th Century, accurate record-keeping and precise information about the distribution of groundwater withdrawals have not always been available. By the mid-1960s, groundwater withdrawals were already estimated to be almost 110 million gallons per day $(\mathrm{Mgal} / \mathrm{d})$ and have increased to more than $250 \mathrm{Mgal} / \mathrm{d}$ by 2010 (Marella, 2004, 2009, 2014) (fig. 4). For the period of record, groundwater withdrawals generally followed population growth until about 2000, after which groundwater withdrawals started to plateau while the population continued to increase (fig. 4). After 2006, a sharp decline in groundwater withdrawals occurred as a result of a concerted effort by Broward County to encourage and implement conservation measures in response to a major drought (figs. 7 $A, 8$ ) (South Florida Water Management District, 2009).

The distribution of groundwater withdrawals has also changed with time, particularly as well fields have been abandoned as a result of saltwater contamination. In general, pumping centers have moved westward, away from the Atlantic coast (fig. 9). Although the primary groundwater source has been the Biscayne aquifer, the Upper Floridan aquifer has been used increasingly as a water supply since 1995. Withdrawals from the Upper Floridan, however, still compose less than 1 percent of the total water withdrawn (Marella, 1999, 2004, 2009, 2014).

\section{Canal System}

An extensive system of canals developed over more than a century is generally designed to convey surface water eastward from the Everglades to the Atlantic Ocean (fig. 10). The canal system acts as both a groundwater source and sink. If the stage in a canal reach is higher than local groundwater levels, the canal recharges the aquifer; if the stage in a canal is lower than local groundwater levels, the aquifer discharges to the canal. Control structures within the canal system are designed to allow or prevent discharge, depending on the hydrologic conditions and required functions. Structures such as gates may be opened when flooding conditions occur or are expected, or closed when recharge to the aquifer is desired because of declining groundwater levels or encroaching seawater in the aquifer. A study of recent hydrologic conditions in Miami-Dade County indicates that over the long term, even with an extensive network of canals and the operation of control structures, the canal system discharges more water from the aquifer than it recharges to the aquifer (Hughes and White, 2014).

Originally constructed to drain swampland, the canal system was progressively expanded and improved to control water-table elevations and reduce flooding during major storm events, and to recharge the shallow aquifer system and resupply the aquifer, thereby maintaining groundwater levels to control saltwater intrusion into the aquifer. By 1950, the major canals that route water from Lake Okeechobee and through the Everglades and Broward County had been built, namely the Hillsboro canal, the New River canal, the South New River canal, and the C-14 canal. During the 1950s, a

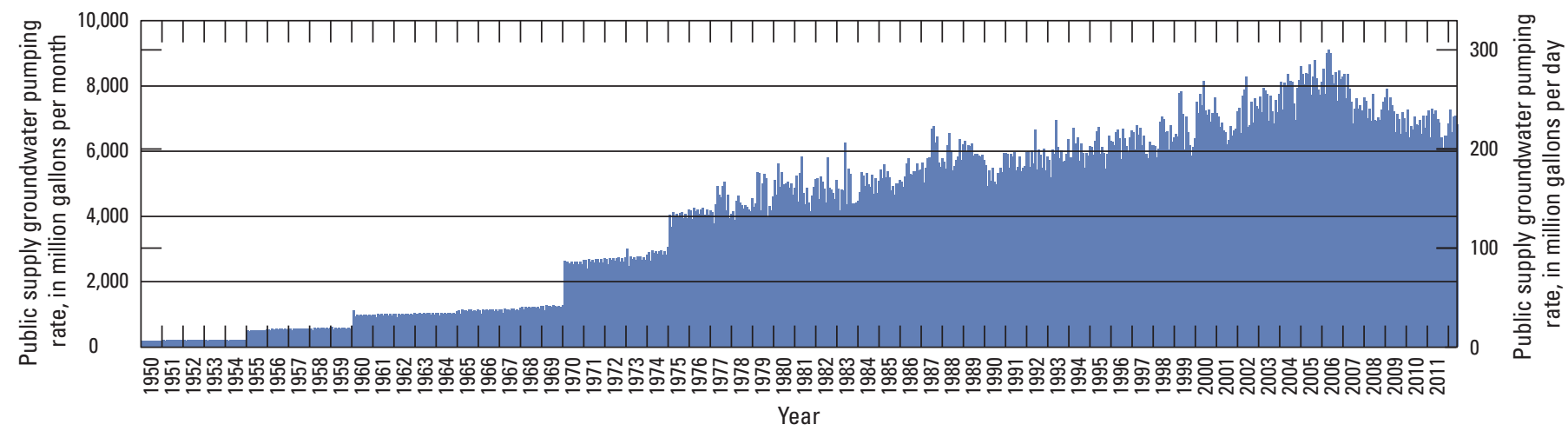

Figure 8. Monthly public-supply groundwater pumping in simulated area. Method of estimating monthly values described in appendix 1 (Marella, 1999, 2004, 2009, 2014; and D. Rickabus, South Florida Water Management District, written commun., October 2012). 


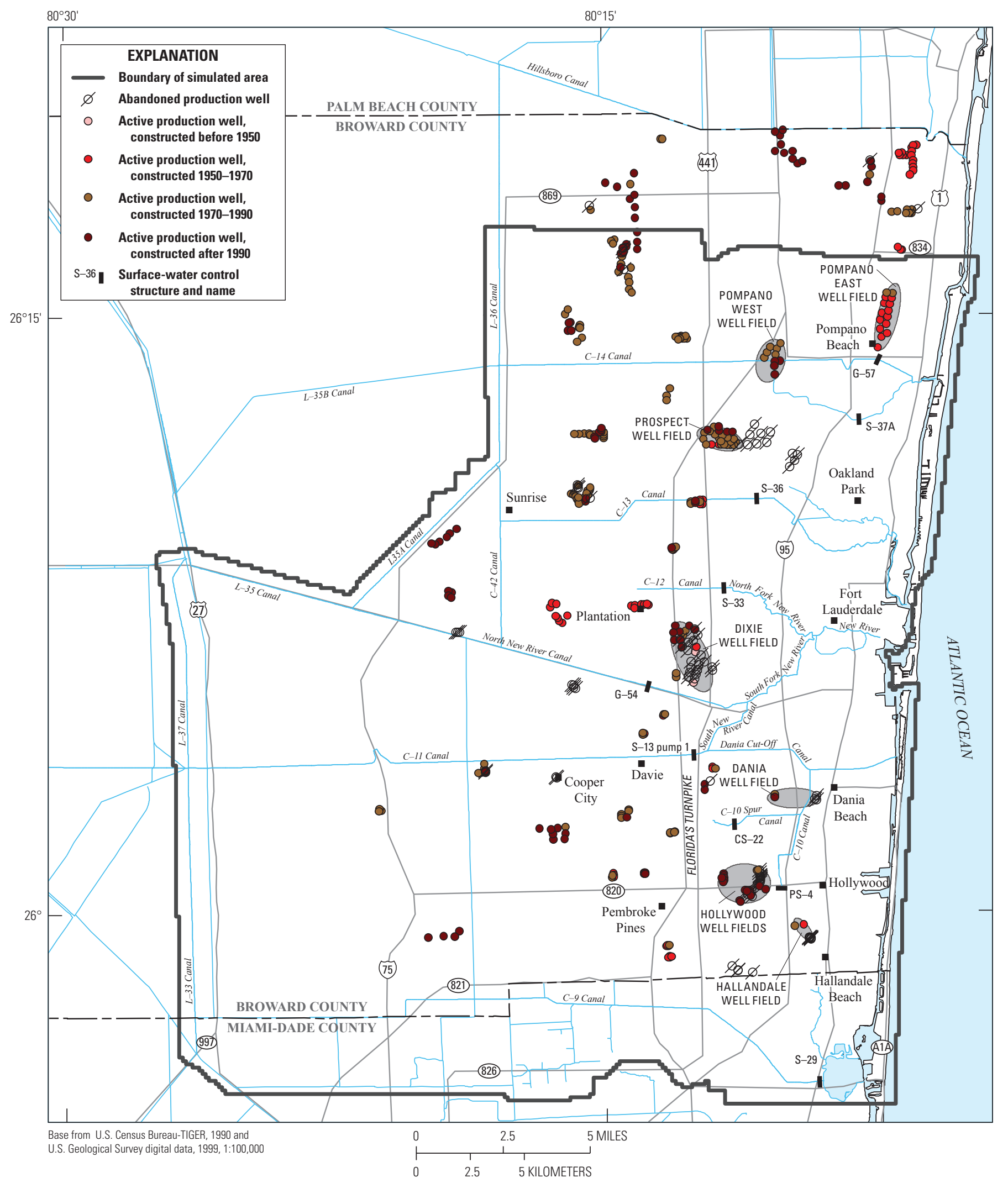

Figure 9. Locations and decadal construction periods of production wells or abandoned wells in the study area. 


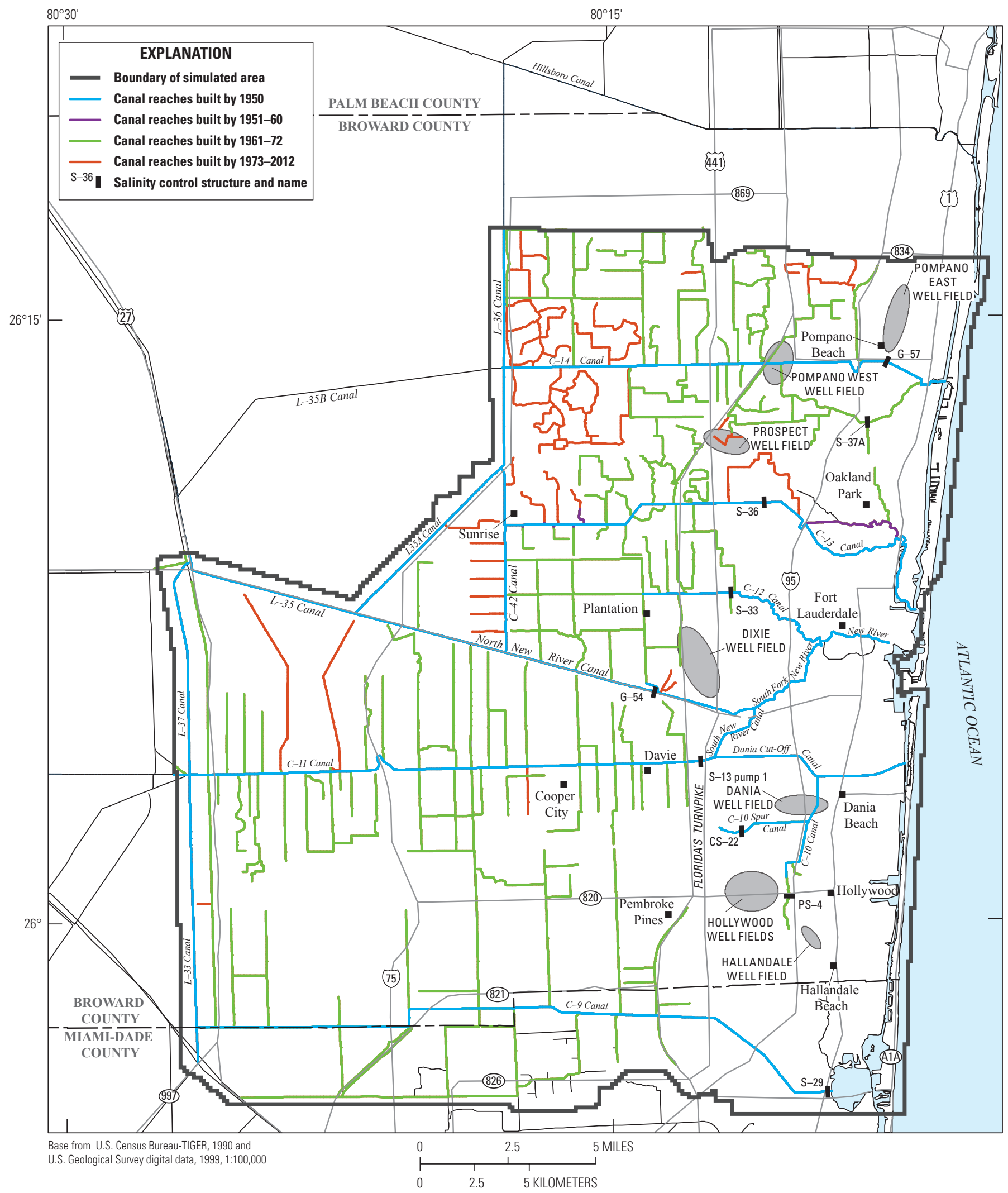

Figure 10. Primary and secondary canals in study area and period of construction (Camp Dresser and McKee and DHI Water and Environment, 2002; DHI Water and Environment and Camp Dresser and McKee, 2005). 
major north-south levee was constructed to protect urbanized areas of Broward and neighboring counties from flooding in the Everglades. During the 1960s, water conservation areas were established in the Everglades west of the urbanized part of the county to delay runoff and prevent overland flow, to control seepage to the surficial aquifer system, and to maintain stage levels in canals in the urbanized part of the county for the purpose of maintaining groundwater levels in, and providing recharge to, the surficial aquifer system. Gated control structures were constructed along the major canals during the 1970s to better control discharge from the canal system into the Atlantic Ocean. Continued urban development has led to additional construction of tertiary drainage features that drain into secondary and primary canals.

\section{Regional Groundwater Flow}

The regional groundwater flow system functions primarily as a source of groundwater for the study area, and to a minor extent, as a sink. Historical potentiometric surfaces of the surficial aquifer system show a low but distinct northwest to southeast gradient, with the development of local cones of depression surrounding major production-well centers, north of the North New River canal (fig. 1), superimposed on the regional surface (Renken and others, 2005). High groundwater levels are maintained in water conservation areas in the western part of the county and by recharge structures to the north, forcing groundwater flow eastward and southeastward toward the coast where levels are lower. Water levels in the water conservation areas are higher during the wet season (June-November) and lower during the dry season (December-May). Pumping increases during the dry season increase drawdown and enlarge existing cones of depression. Thus, the eastward to southeastward groundwater flow gradient may be larger in the wet season than in the dry season, generating more regional groundwater flow into the study area, but the general direction is unchanged. The northern and southern boundaries of the study area are approximately parallel to the predominant regional flow direction, but locally some groundwater may enter or leave across these boundaries, particularly along the southern boundary.

\section{Salinity Distribution}

At the county scale, the salinity distribution has been mapped as a line indicating a freshwater-saltwater interface (fig. 11) (Dunn, 2001; Renken and others, 2005; South Florida Water Management District, 2011). This mapped interface reflects the conceptual model of saltwater intrusion, which indicates that in coastal aquifers, higher-density saltwater may intrude into aquifers onshore beneath land surface to a position where the hydraulic head of fresh groundwater equals that of saltwater (fig. 2). In cross section, this conceptual model shows the freshwater-saltwater interface as a wedge, with freshwater overlying saltwater, and the toe, or deepest part of the interface in an aquifer, farthest inland. Along the wedge-shaped interface, the hydraulic head of the overlying, lower-density freshwater is equivalent to the hydraulic head of the underlying, higher-density saltwater. At a more local scale, the freshwater-saltwater interface represents a specified salinity within a transition zone, at its most landward position in cross section, usually at the base of the aquifer. The freshwater-saltwater interface commonly represents a chloride concentration of $250 \mathrm{mg} / \mathrm{L}$ (for example, South Florida Water Management District, 2011), which is the EPA drinking water standard, but other values may be used; for example, $1,000 \mathrm{mg} / \mathrm{L}$ (Prinos and others, 2014) or $100 \mathrm{mg} / \mathrm{L}$ (Renken and others, 2005).

The freshwater-saltwater interface also reflects sources of saltwater intrusion at a more local scale than those just discussed; for example, downward leakage of saltwater from tidally affected canals or coastal creeks. This type of groundwater salinity source has been documented in Miami-Dade County (Prinos and others, 2014). Some areas of elevated groundwater salinity in Broward County may also be explained by this source.

Maps of the freshwater-saltwater interface from 1945 to 2009 generally show its westward migration in southeastern Broward County (fig. 11). In 1945, the interface was east of the Dania, Hallandale, and Hollywood well-field areas. Between 1945 and 1969, the interface migrated into the Dania well-field area. By 1996, the interface had migrated to a position just east of the Hallandale well-field area, and to the aquifer beneath the $\mathrm{C}-11$ canal. By 2009, the interface had migrated west of the Dania well-field area, into the Hallandale well-field area, and it has continued to move toward the Hollywood and Dixie well-field areas. Caution must be used in interpreting the details of the interface maps, because the maps are generated using the best available data at a specified time. Accurate mapping requires use of consistent datasets through time and wells optimally designed to identify the interface (Prinos, 2013). Some apparent movement of the interface, either landward or seaward, may be an artifact of the addition of new monitoring sites (Prinos and others, 2014), or differences in reference salinity.

The salinity distribution near the freshwater-saltwater interface is most precisely represented as a transition zone from freshwater to seawater (or higher) salinity concentration. The transition zone reflects the dispersive processes that occur during the mixing of miscible fluids that have differing densities and solute concentrations. The width or thickness of this transition zone can vary considerably, depending on (1) the hydraulic properties of the aquifer and (2) the hydraulic gradients, particularly of the freshwater-bearing, onshore part of the hydrologic system. At G-2903 in Hallandale Beach, a gradual increase in salinity, indicated by the general increase of the bulk conductivity from about 20 to $400 \mathrm{mS} / \mathrm{m}$ over an interval from about 80 to more than $150 \mathrm{ft}$ depth, indicates a wide transition zone (figs. 11, 12). In contrast, at G-2896 in Pompano Beach, bulk conductivity increases from about 20 to $300 \mathrm{mS} / \mathrm{m}$ over a depth interval of about 90 to $100 \mathrm{ft}$, 


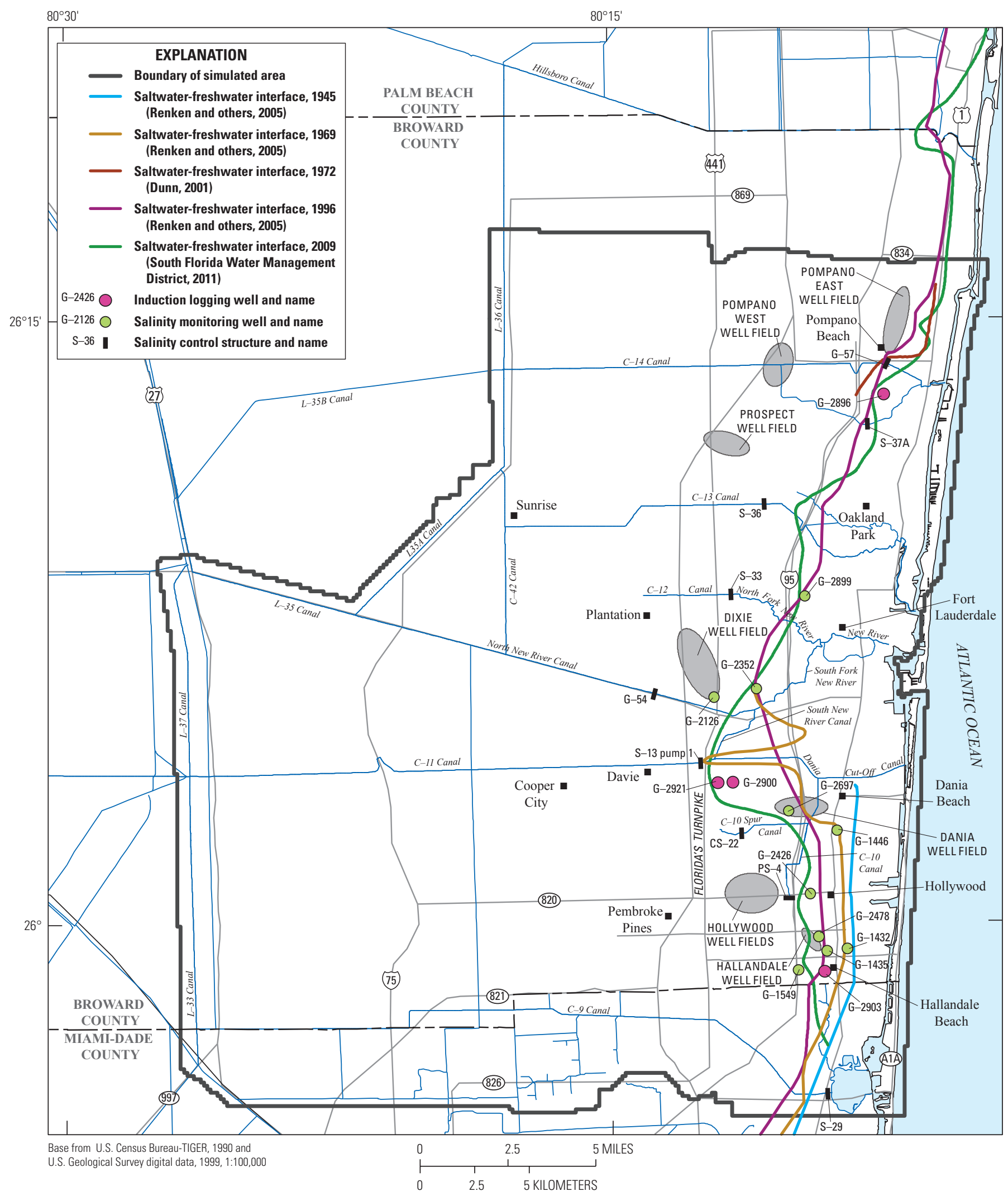

Figure 11. Freshwater-saltwater interfaces in the Biscayne aquifer in Broward County, 1945, 1969, 1972, 1996, and 2009; locations of salinity data used to calibrate the model, and induction log data; and well-field areas. Interface locations are based on chloride concentrations of 250 milligrams per liter (mg/L) (1945, 1969, 1972, 2009) or 100 mg/L (1996). 


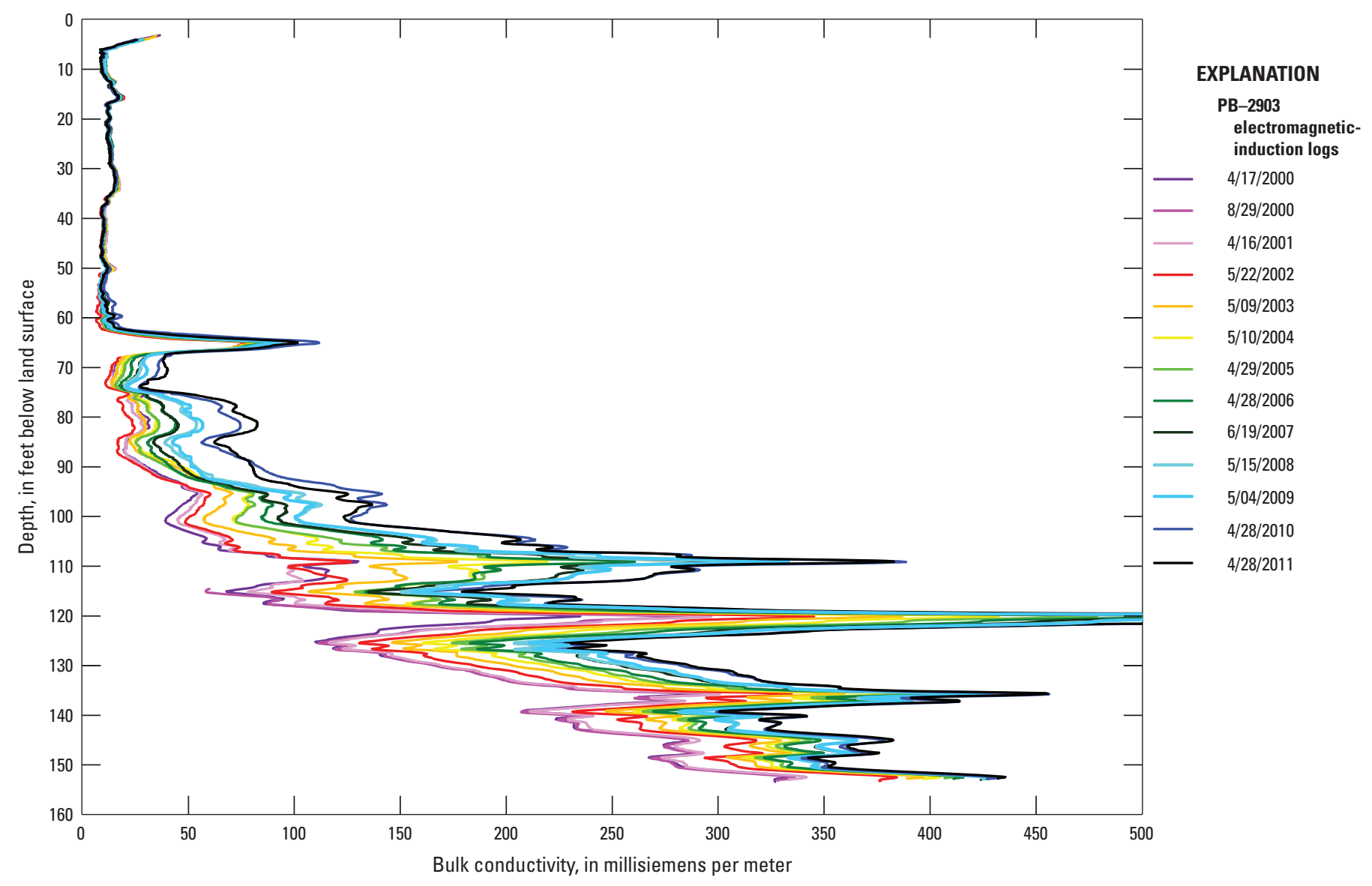

Figure 12. Electromagnetic induction logs at G-2903 in Hallandale Beach, 2000-11 (U.S. Geological Survey, 2012a).

indicating a narrow transition zone (figs. 11, 13). For the purpose of this report, the terms "freshwater-saltwater interface," or "interface," will be used to represent, in a general manner, the transition zone between saline groundwater advancing from marine sources in the eastern part of the study area and fresh groundwater flowing toward the coast from onshore sources, except as indicated otherwise as a mapped interface.

Temporally and at a local spatial scale, salinity in coastal aquifers is variable. Temporal variability can be evaluated in samples collected from a discrete depth interval at regular temporal intervals over a long period of time. Variability is generally less pronounced at low salinities than at higher salinities. For example, at G-2426 in Hollywood, water samples collected from a depth of about $90 \mathrm{ft}$ every 1 to 3 months during 1986-2013 indicate that salinity ranged from about 10 to $60 \mathrm{mg} / \mathrm{L}$ chloride (fig. $14 A-B$ ). In contrast, at G-2900 in Davie, monthly samples collected from a depth of about $115 \mathrm{ft}$ during 2000-13 show that salinity values ranged from about 2,000 to more than 4,500 $\mathrm{mg} / \mathrm{L}$ and that the variation within any given year was about $1,000 \mathrm{mg} / \mathrm{L}$ (fig. 14C). On a multi-year scale, salinities may vary by several orders of magnitude as the saltwater interface is advancing. For example, at G-1435 in Hallandale Beach, chloride concentration measured at a depth of about $204 \mathrm{ft}$ ranged from 24 to $11,000 \mathrm{mg} / \mathrm{L}$ during the $1969-2013$ period of record (fig. 14A). The periods of record at $\mathrm{G}-2352$ and $\mathrm{G}-2478$ are also long enough to show temporal changes in salinity as the saltwater interface advances at those locations (fig. 14A).

Temporal changes in salinity can also be inferred across a longer depth interval using induction log time series. At G-2903 in Hallandale Beach, induction logs indicate bulk conductivity generally increases with depth over the depth interval from about 70 to $150 \mathrm{ft}$ during 2000-11 (figs. 11, 12). Bulk conductivity represents the conductivity of both the solid aquifer substrate and the groundwater. The conductivity of the aquifer substrate does not change; thus, the groundwater conductivity is increasing because of increasing salinity. 


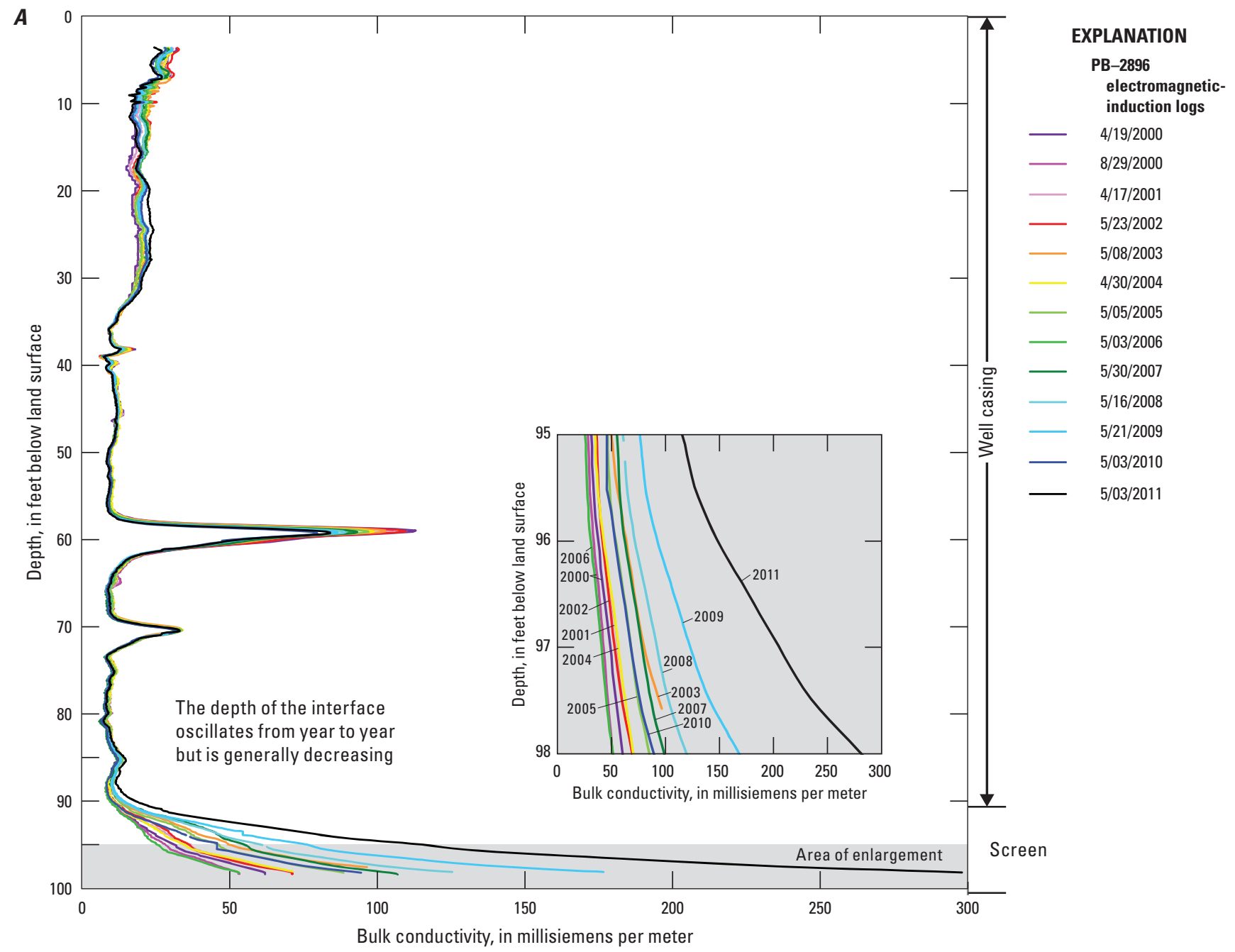

B

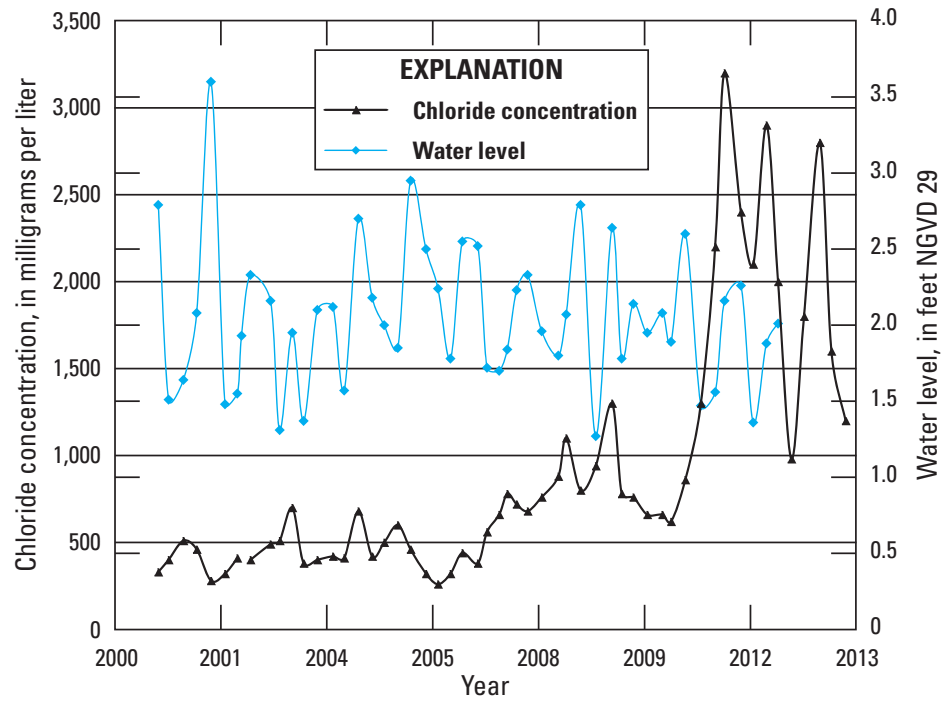

Figure 13. $A$, Electromagnetic induction logs and $B$, chloride concentration and water level at G-2896 in Pompano Beach, 2000-11 (U.S. Geological Survey, 2012c; U.S. Geological Survey, 2014). 

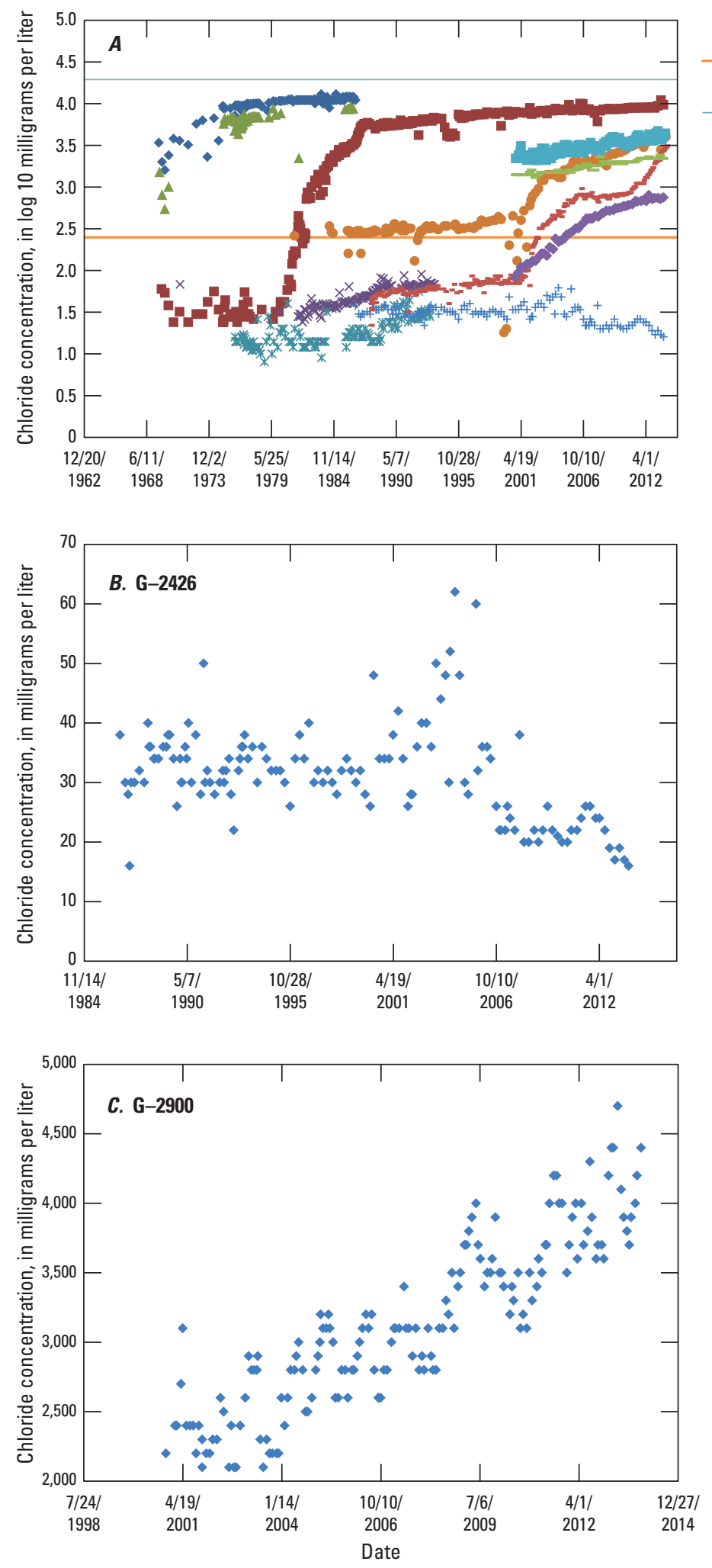

Figure 14. Salinity concentrations versus time for $A$, all calibration wells in study area, $B$, at $\mathrm{G}-2426$ in Hollywood, and C, at G-2900 in Davie (U.S. Geological Survey, 2014).
EXPLANATION

250 milligrams per liter

Seawater

G-1432

- G-1435

G-1446

G-1549

G-2126

G-2352

G-2426

G-2478

G-2697

G-2899

G-2900
Induction logs can indicate vertical variability in salinity. Although variability in the depth interval of the transition zone is shown in induction logs collected at G-2903 and G-2896 (figs. 12, 13), the induction logs collected at G-2900 and G-2921 in Davie indicate that salinity may not always increase with depth (figs. 11, 15, and 16). Sharp vertical transitions in bulk conductivity may be indicative of a large difference in salinity over a short depth interval. Positive transitions in the downward direction, which are not reflective of aquifer substrate properties, may indicate increasing salinity, whereas negative transitions in the downward direction may indicate decreasing salinity. The induction logs at G-2900 and G-2921 (figs. 15 and 16) show both positive and negative transitions in conductivity, indicating the possibility of increasing or decreasing salinity with depth. The presence of intervals of both increasing and decreasing salinity with depth may indicate the variability in flow properties of the aquifer, such as between flow zones and semiconfining zones, and how readily saline water may be transported vertically and horizontally through these zones.

Salinity generally increases toward the coast in the study area, as indicated by salinities at wells G-1432 and G-1435 in Hallandale Beach (figs. 11 and 14A). During 1969-86 when both wells were sampled, salinities in G-1432 were higher than those less than 1 mile west in $\mathrm{G}-1435$, ranging from approximately 1,000 to $10,000 \mathrm{mg} / \mathrm{L}$ chloride and from 100 to less than $10,000 \mathrm{mg} / \mathrm{L}$ chloride, respectively (fig. 14A). Well G-1435 is less than 1 mile southeast of G-2478, also in Hallandale Beach (fig. 11). Salinities at G-1435 have remained higher than salinities at G-2478 since 1988, when both wells were sampled (fig. 14A). In contrast, salinities at G-2426 in Hollywood, located over 1 mile north and slightly west of G-2478, have remained below $100 \mathrm{mg} / \mathrm{L}$ chloride since 1986. Estimates of the freshwater-saltwater interface show that the location of the interface may not parallel the coast exactly (Merritt, 1996; South Florida Water Management District, 2011; Langevin and Zygnerski, 2013), because factors other than proximity to the Atlantic Ocean affect groundwater salinity. For example, background salinity values at G-2352 in the city of Ft. Lauderdale from 1981 to about 1999 are an order of magnitude higher than background salinity values in G-2426 in Hollywood, and G-1435 and G-2478 in Hallandale Beach. The higher background salinity values at G-2352 are possibly the result of long-term, historical downward leakage of saline tidal water from the nearby South Fork New River canal into the aquifer. 


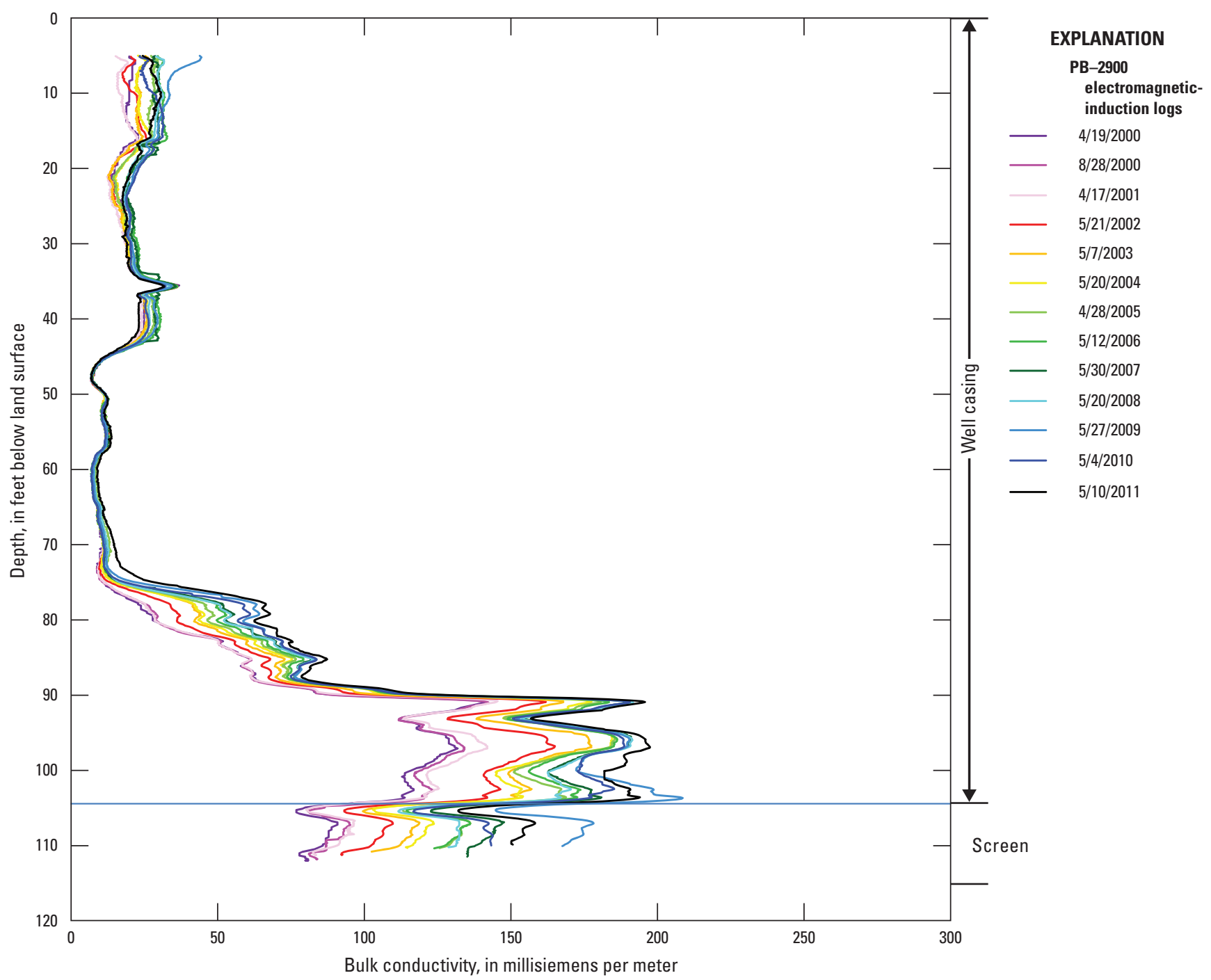

Figure 15. Electromagnetic induction logs at G-2900 in Davie, 2000-11 (U.S. Geological Survey, 2012b). 


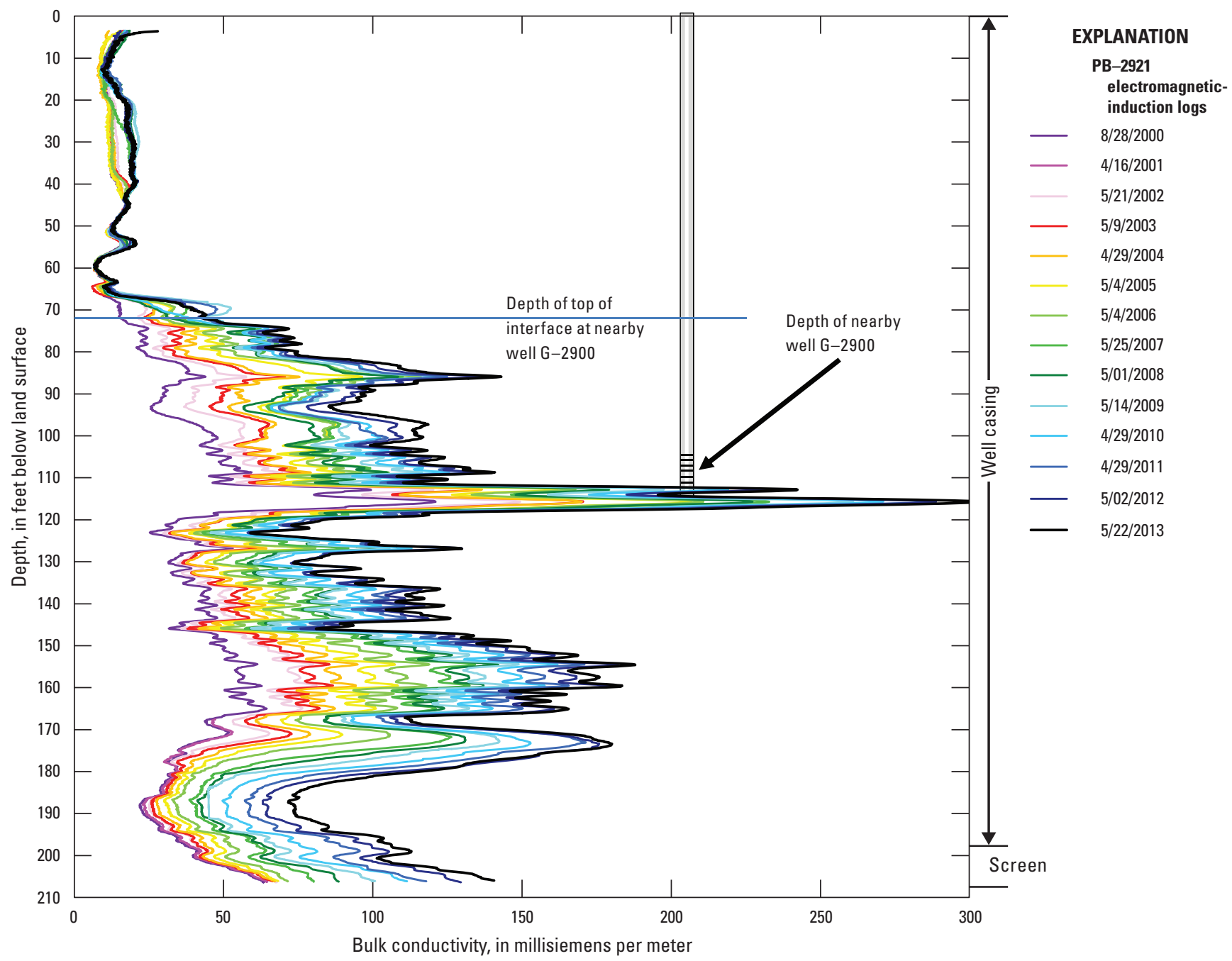

Figure 16. Electromagnetic induction logs at G-2921 in Davie, 2000-11 (U.S. Geological Survey, 2013). 


\section{Effects of Groundwater Pumping and Sea-Level Rise on Simulated Salinity Distribution}

The SEAWAT model of the study area was constructed to simulate saltwater intrusion in the Biscayne aquifer and accounts for groundwater pumping and sea-level rise, as well as recharge from precipitation and canals, evapotranspiration, and regional groundwater flow (appendix 1). Groundwater flow is simulated in the entire model domain, and the portion of the model domain potentially affected by saltwater intrusion during the simulated timeframe was made to actively simulate chloride transport. The model represents monthly time steps from January 1950 to May 2012. It was calibrated to groundwater levels at 15 sites, representative chloride concentrations at 11 sites, and flow-weighted well-field chloride concentrations. The 11 sites from which chloride concentration data were used for calibration were located in the central and southern parts of the county because (1) a previously developed model was calibrated for the northern part of the county (Langevin and Zygnerski, 2013), and (2) most of the water-supply well fields of imminent concern for future saltwater intrusion are south or just north of the New River. Qualitative and quantitative comparisons of model results to interpreted freshwater-saltwater interface positions and observed groundwater levels and chloride concentrations (model fit), respectively, are also presented in appendix 1. The model was used to test the sensitivity of salinity distribution and transport to groundwater pumping and sea-level rise.

\section{Historical Simulation}

The simulated distribution of salinity at the end of 2011 is roughly parallel to the coast with lobes and patches of elevated salinity extending landward and downward (figs. 17, 18). In map view, the northern part of the intruded area closely parallels the coast and shows a narrow transition from highest to lowest concentrations, indicating a steep salinity gradient. The isochlors in the central and southern part of the intruded area are more widespread and irregular, indicating a broader, more diffuse freshwater-saltwater interface. In profile, salinity concentrations also are highest closest to the coast, and a roughly wedge-shaped distribution of the highest concentrations is evident, indicating greater landward movement of denser water at depth, and a more irregular near-surface landward distribution of less dense, lower-salinity water (fig. 18). These features indicate a stronger influence of the offshore forcing of seawater on the salinity distribution in the northern and southern intruded area, and a stronger combined influence of saline surface water leaking downward in tidally influenced parts of the canal network, freshwater recharge, and dispersion processes in the central intruded area. Increased salinity extending along the North New River and Dania Cut-Off canals is caused by downward leakage of saltwater that has migrated upstream in the canals (figs. 17 and 19, $\left.F-F^{\prime}, G-G^{\prime}\right)$. A freshwater lobe extending from the C-10 canal southwestward toward the Hollywood well-field area is the result of a combination of freshwater leaking downward through the $\mathrm{C}-10$ canal and saline water migrating landward at depth from the coast (figs. 17 and 19A, $H-H^{\prime}$ ).

The simulated extent of salinity in 2011 is comparable to the 2009 mapped freshwater-saltwater interface (fig. 17) but exhibits more complexity; both generally parallel the coast and extend inland in the central part of the intruded area, where salinity control structures are farther inland than in areas to the north and south. Comparisons between the simulated distribution of salinity in 2011 and the 2009 mapped freshwatersaltwater interface must be considered in light of differences in analyses. The mapped interface is the estimated location of the $250-\mathrm{mg} / \mathrm{L}$ isochlor at its farthest inland extent in the surficial aquifer system (South Florida Water Management District, 2011). It is interpolated qualitatively based on selected waterquality data from monitoring and production wells of variable depth and open-interval length. The actual salinity distribution is a three-dimensional feature of variable concentration; the mapped interface is a two-dimensional representation of a reasonable expectation of how far inland elevated salinity may exist in the underlying aquifer system. For example, the 2009 mapped interface is interpreted to be west of G-2426, even though concentrations in that well are less than $100 \mathrm{mg} / \mathrm{L}$ (figs. 14A, 17; South Florida Water Management District, 2011). Well G-2426 is open near the bottom of the Biscayne aquifer, but in deeper wells in the surficial aquifer system, such as G-2956 west of G-2426, concentrations are closer to $250 \mathrm{mg} / \mathrm{L}$ (South Florida Water Management District, 2011). The simulation results show the distribution and concentration of salinity in a selected model layer, in this case, layer 10 representing the base of the Biscayne aquifer. Results for this model layer are shown rather than those for the bottom of the model because the objective of the model is to evaluate salinity in the Biscayne aquifer. Furthermore, selecting the layer representing the Biscayne aquifer base, instead of a shallower model layer or the most inland position of elevated salinity in any layer, better represents the overall movement of the freshwater-saltwater interface and allows results of different hydrologic condition scenarios to be easily compared to one another. The simulated distribution of salinity is calculated for individual model cells and thus shows much more complexity than the mapped interface can show. The simulated salinity distribution is calculated using a variable-density solute transport model, which was calibrated to match data at selected sites as closely as possible; the two-dimensional mapped interface was not used in the model calibration. The calibration wells were selected on the basis 


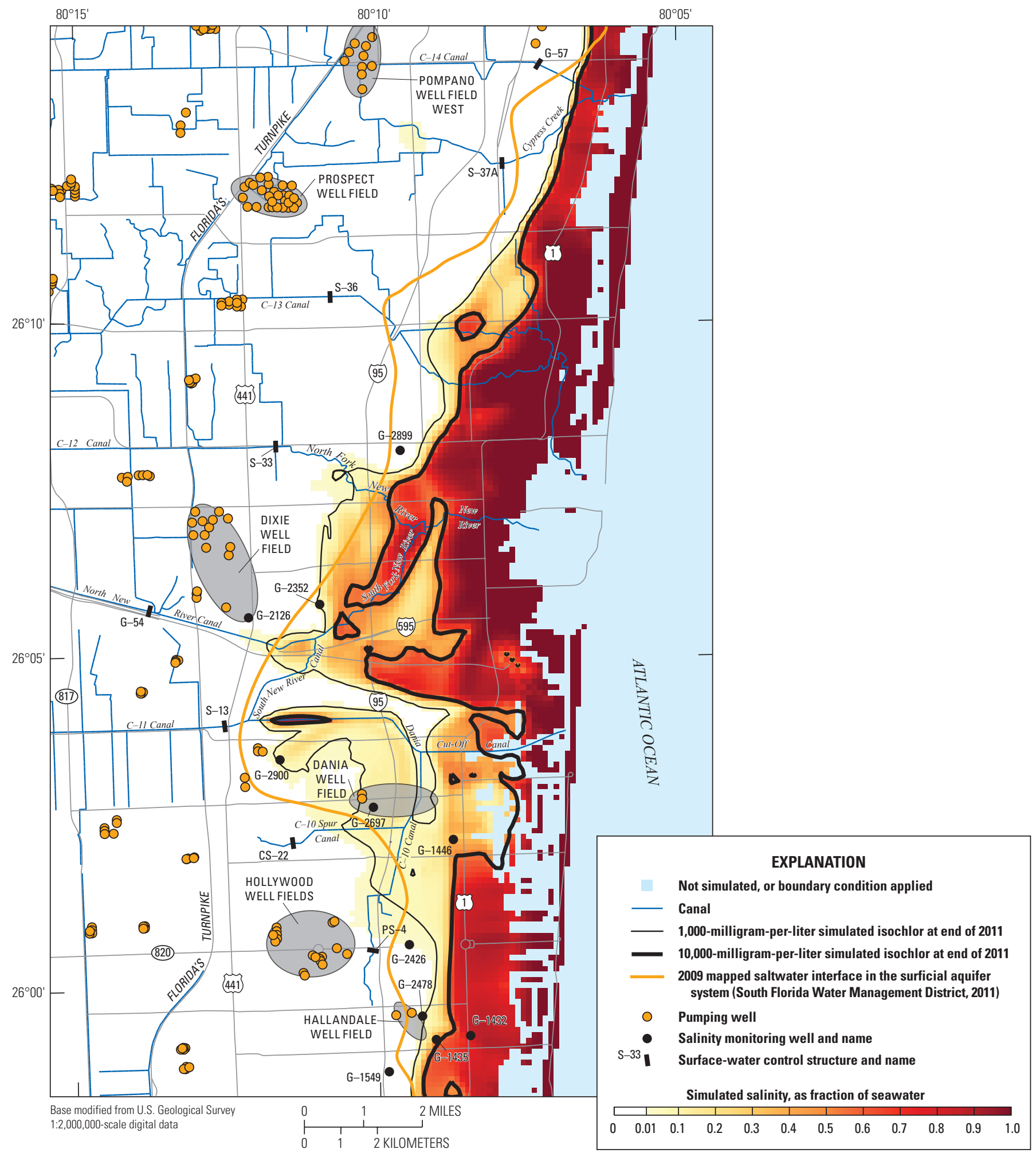

Figure 17. Simulated distribution of salinity at the base of the Biscayne aquifer at the end of 2011. 


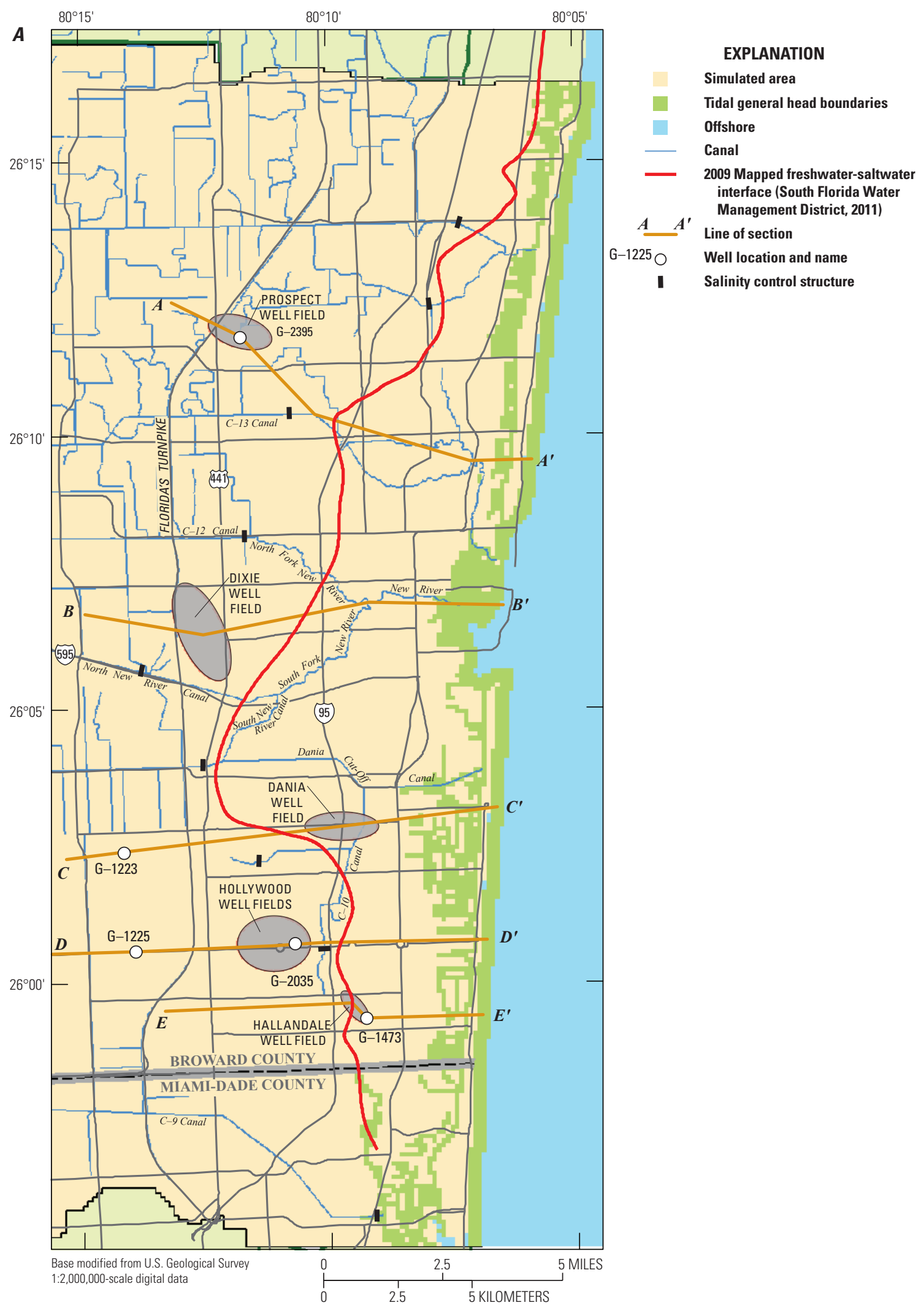

Figure 18. A, Locations of cross sections and $B$, cross sections of simulated salinity distribution at the end of 2011. 


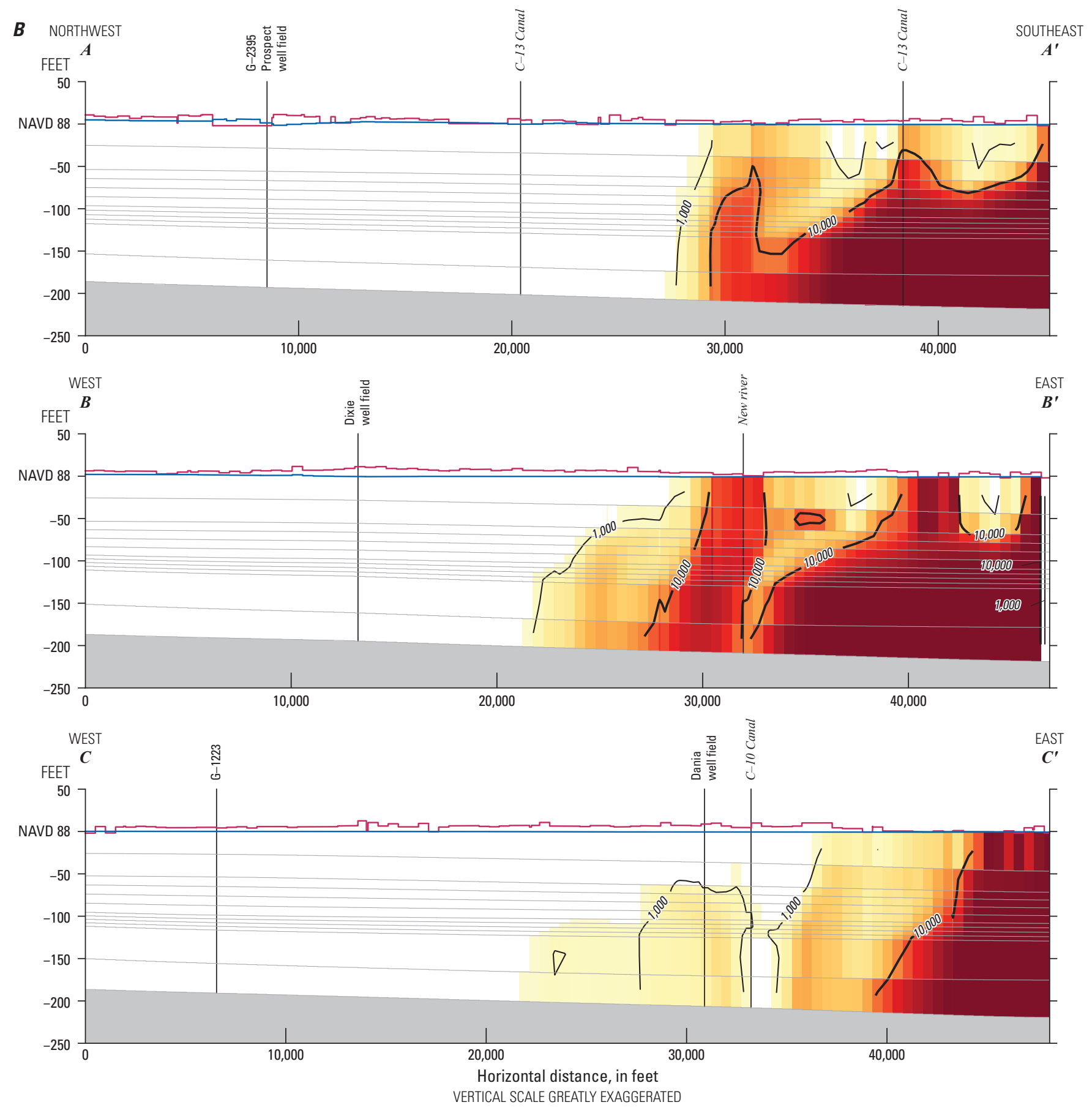

EXPLANATION

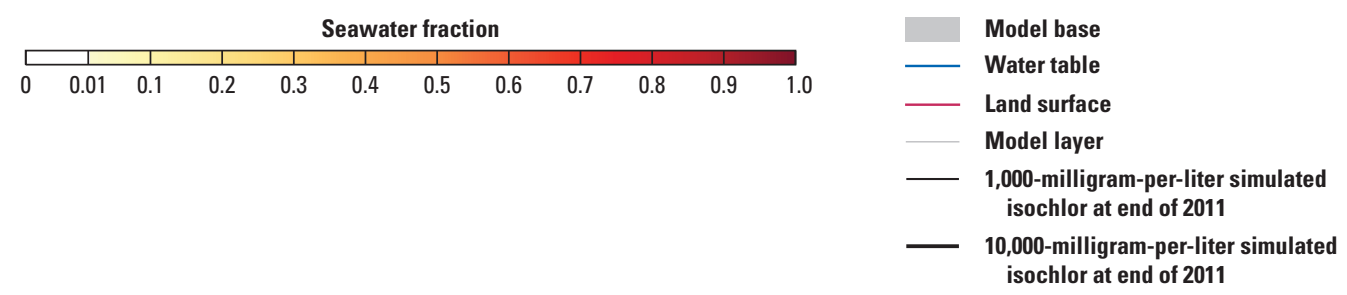

Figure 18. $A$, Locations of cross sections and $B$, cross sections of simulated salinity distribution at the end of 2011 . -Continued 


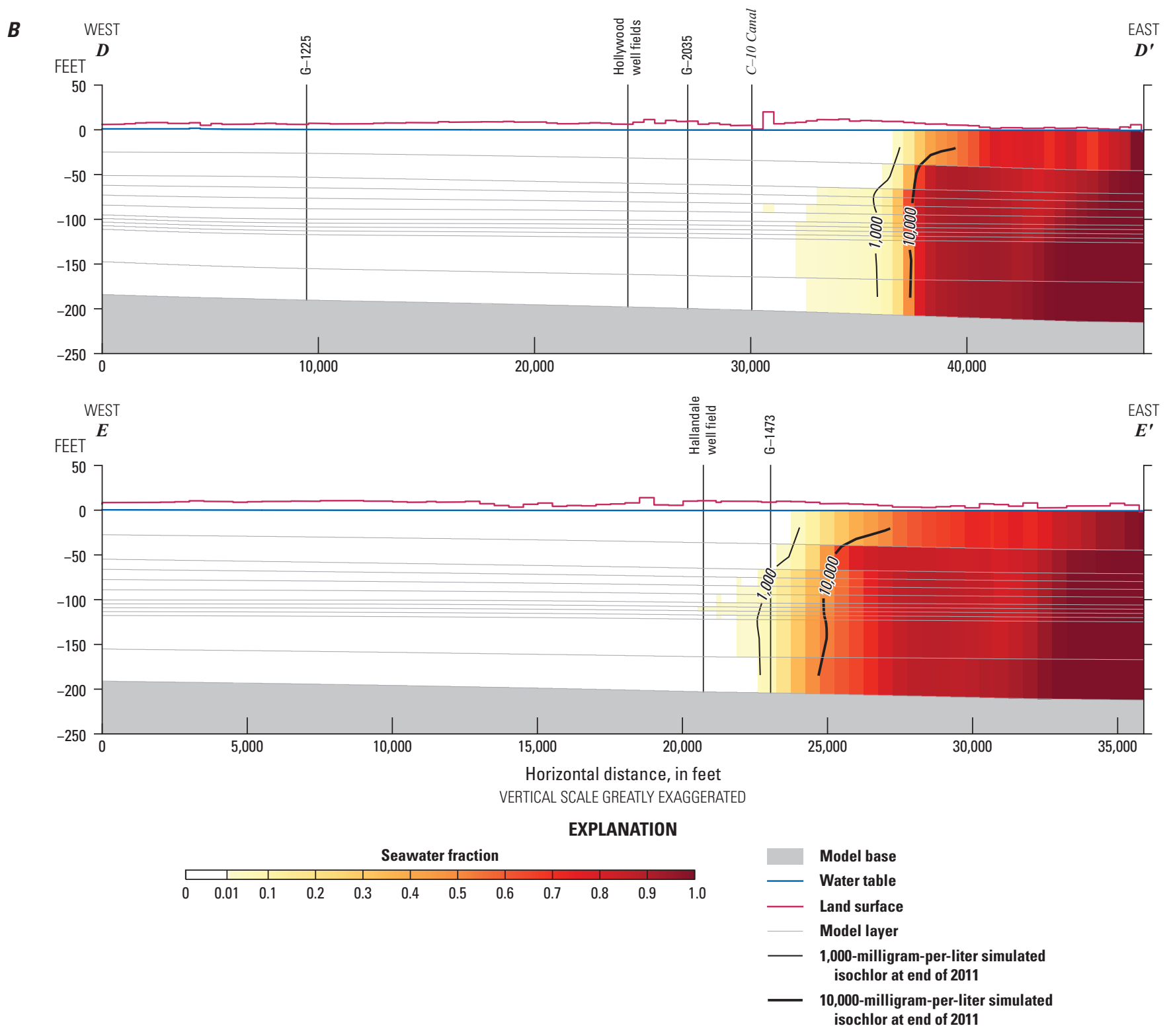

Figure 18. A, Locations of cross sections and $B$, cross sections of simulated salinity distribution at the end of 2011. -Continued 


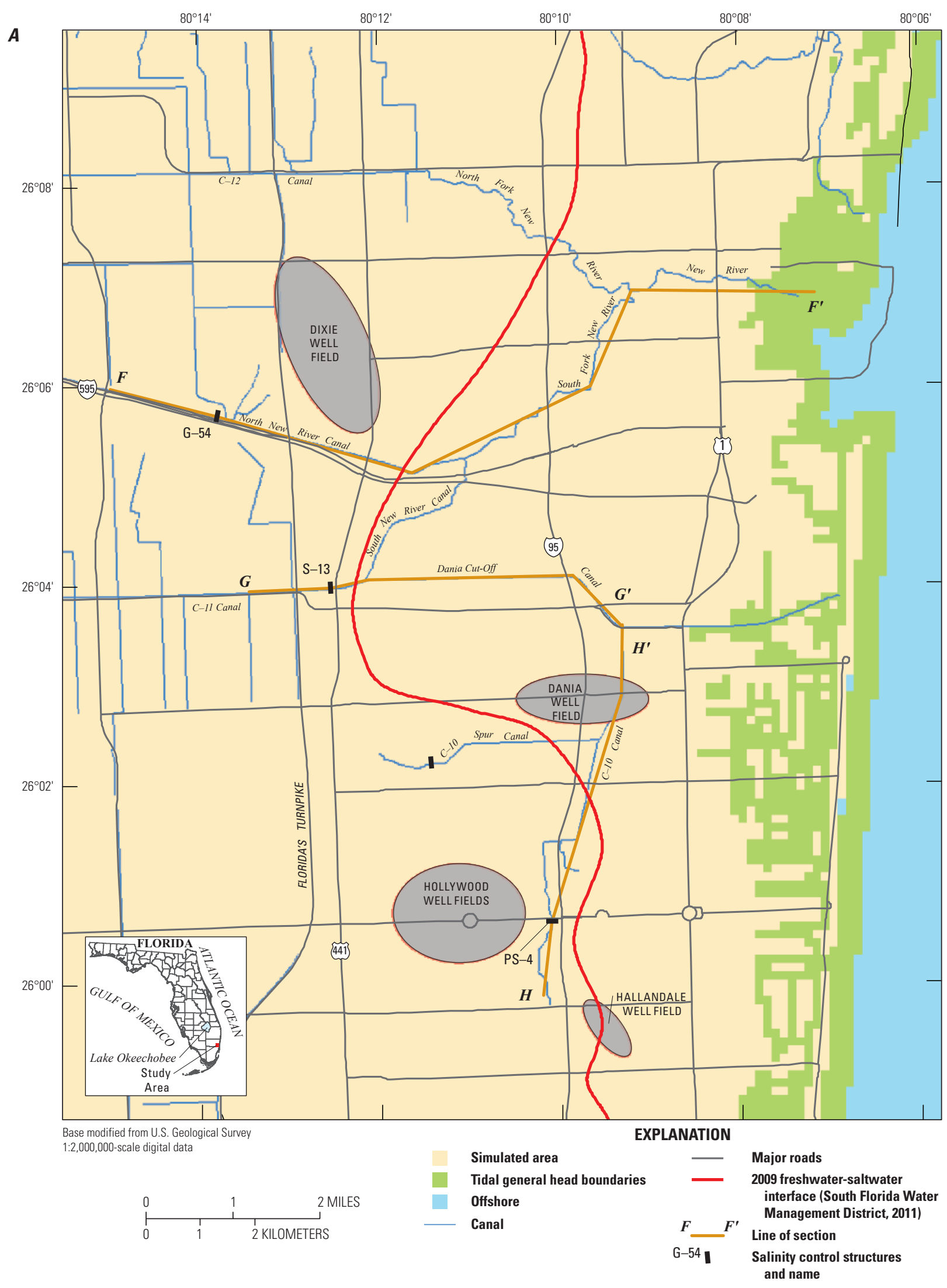

Figure 19. A, Locations of cross sections and $B$, cross sections of simulated salinity distribution at the end of 2011 . 
$\boldsymbol{B}$
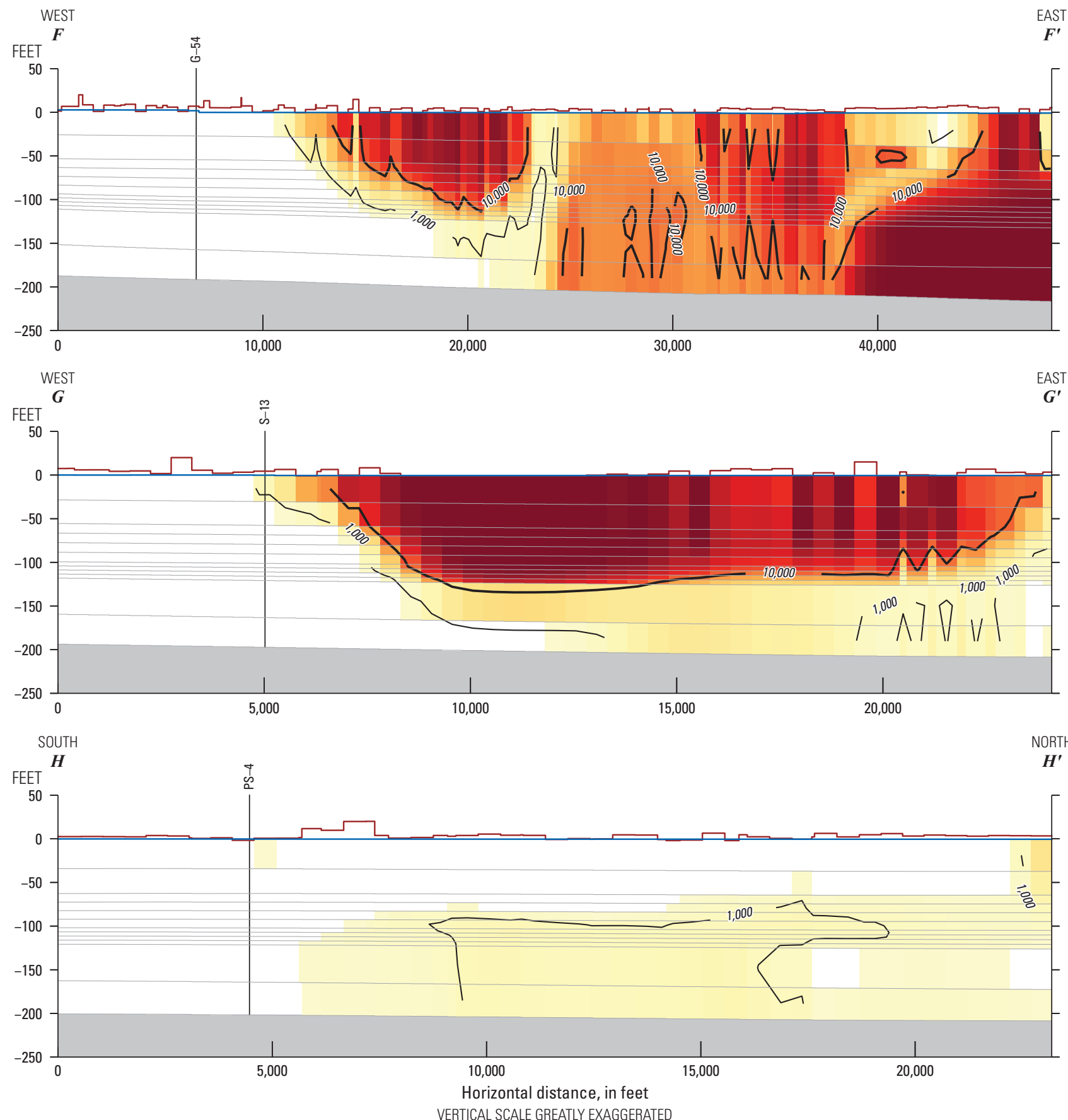

EXPLANATION
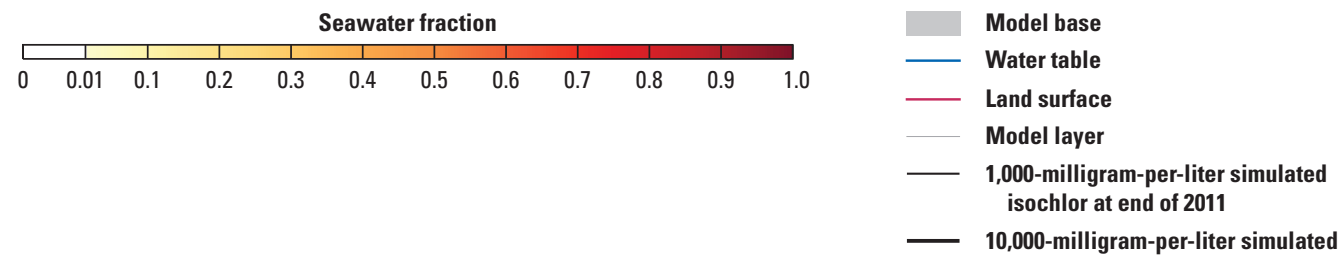

isochlor at end of 2011

Figure 19. $A$, Locations of cross sections and $B$, cross sections of simulated salinity distribution at the end of 2011 . -Continued 
of depth, open interval length (shorter open intervals provide more precise data), historical record length, and proximity to the known area of elevated groundwater salinity (appendix 1; Prinos, 2013). Because of these conceptual differences in the analyses, the simulated results would not be expected to match the mapped interface, which was estimated using limited data. Nonetheless, a comparison of the simulation results with the mapped interface may provide useful insight for interpreting model results.

In the northern part of the intruded area, the simulated extent of elevated salinity at the end of 2011 is not as far inland as the mapped 2009 interface (fig. 17). The mapped interface between G-2899 and the Pompano well-field area is interpreted using nine control points (South Florida Water Management District, 2011); the northernmost control point for the model is well G-2899 (fig. 17), which is used for model calibration. The simulated time series at G-2899 shows a decreasing trend in chloride (hence, salinity), rather than the observed increasing trend (fig. 1-21J), indicating that the model generally underestimates salinity and incorrectly simulates the directionality of trends in salinity at this location during the period for which data are available. In the area near the confluence of the North New River and South New River canals, and along the Dania Cut-Off canal, the simulated extent of elevated salinity is generally similar to the extent of the 2009 mapped interface (fig. 17). Notably, however, the model simulates salinity trends opposite of what are observed at several other calibration locations in this region (G-2352, G-2900, G-2697; fig. 1-21F, $K$, and $I$ ). East of the Hollywood and Hallandale well-field areas, the simulated landward extent of salinity is not quite as far west as the mapped interface. For the four calibration sites near and south of the Hallandale well-field area (G-2478, G-1435, G-1432, and $\mathrm{G}-1549)$, simulation results match time-series salinity data closely (fig. 1-21H, $B, A$, and $D$ ), indicating the differences between the simulated salinity distribution and mapped interface are probably related to conceptual differences between the mapped and simulated interfaces.

Long-term movement of the interface is best illustrated at higher concentrations, where it is more resistant to short-term variability in stresses, such as pumping or recharge, or initial conditions. The simulated movement of salinity during the study period is partially dependent on initial conditions, so results before 1970 are not interpreted because the effects of initial conditions are strongest during that period. Thus, long-term movement of the interface was evaluated for the $10,000-\mathrm{mg} / \mathrm{L}$ isochlor after 1970 . Where simulated $10,000-\mathrm{mg} / \mathrm{L}$ isochlors are very closely spaced or overlapping, the interface has not moved much since 1970, particularly in the northern part of the intruded area (fig. 20). Results also show generally progressive inland movement along the North New River canal and southeast of the Hallandale well-field area. Near the Hallandale well-field area, the 10,000-mg/L isochlor moved substantially between 1970 and 1990, then minimally thereafter. This arrested landward movement of the isochlor represents the response of the interface to a pumping plateau at Hallandale well field in the early 1980s, followed by a reduction in pumping by almost 50 percent by the late 1990s. East of the Dania well-field area, the simulated extent of salinity decreases as a result of higher simulated salinity values at initial conditions relative to observed values (fig. 1-21I).

\section{Sensitivity to Groundwater Pumping and Sea-Level Rise}

The sensitivity of the simulated salinity distribution was tested by running the model for the 62-year historical period without historical (1) pumping, (2) sea-level rise, and (3) pumping and sea-level rise. Monthly tidal stages from 1950 were used for each year in the January 1950 to May 2012 simulation period to remove the effects of historical sea-level rise in the model for the two sensitivity tests without sea-level rise. All other conditions for the 1950 to 2012 simulation period remained the same as for the calibrated model (table 1). For discussion purposes, the simulation without pumping is referred to as Sensitivity Simulation 1, the simulation without historical sea-level rise is Sensitivity Simulation 2, and the simulation with neither pumping nor historical sea-level rise is Sensitivity Simulation 3. These simulations are compared against the historical simulation.

\section{Sensitivity Simulation 1: Effects of Pumping}

Results for Sensitivity Simulation 1 indicate that when pumping is eliminated, the resulting groundwater levels are higher at the end of the simulation relative to the historical simulation (fig. 21). Water levels are up to $0.5 \mathrm{ft}$ higher in the Hollywood well-field area and even higher near pumping locations west of there. Water levels are more than $1 \mathrm{ft}$ higher in the Dixie well-field area and in the Plantation well field, north of Dixie, and more than $0.5 \mathrm{ft}$ higher near pumping centers to the northwest of the Dixie well-field area. Water levels at the Dania and Hallandale well-field areas are slightly higher than those for the historical simulation. For Sensitivity Simulation 1, simulated 1,000-mg/L isochlors at the end of 2011 indicate that the extent of the intruded area is generally the same or closer to the coast and smaller (fig. 22), compared with the historical simulation. In particular, the extent of the intruded area is reduced at the confluence of the North New River and South New River canals, and near the Dania and Hollywood well-field areas, relative to the historical simulation. Removal of pumping stresses results in increased groundwater levels in many of the well-field areas. This prevents salinity from migrating as far inland as it would with pumping stresses. The extent of the intruded area along the Dania Cut-Off canal is similar to that in the historical simulation, because the source of salinity is downward leakage from the canal, which is not affected substantially by pumping. 


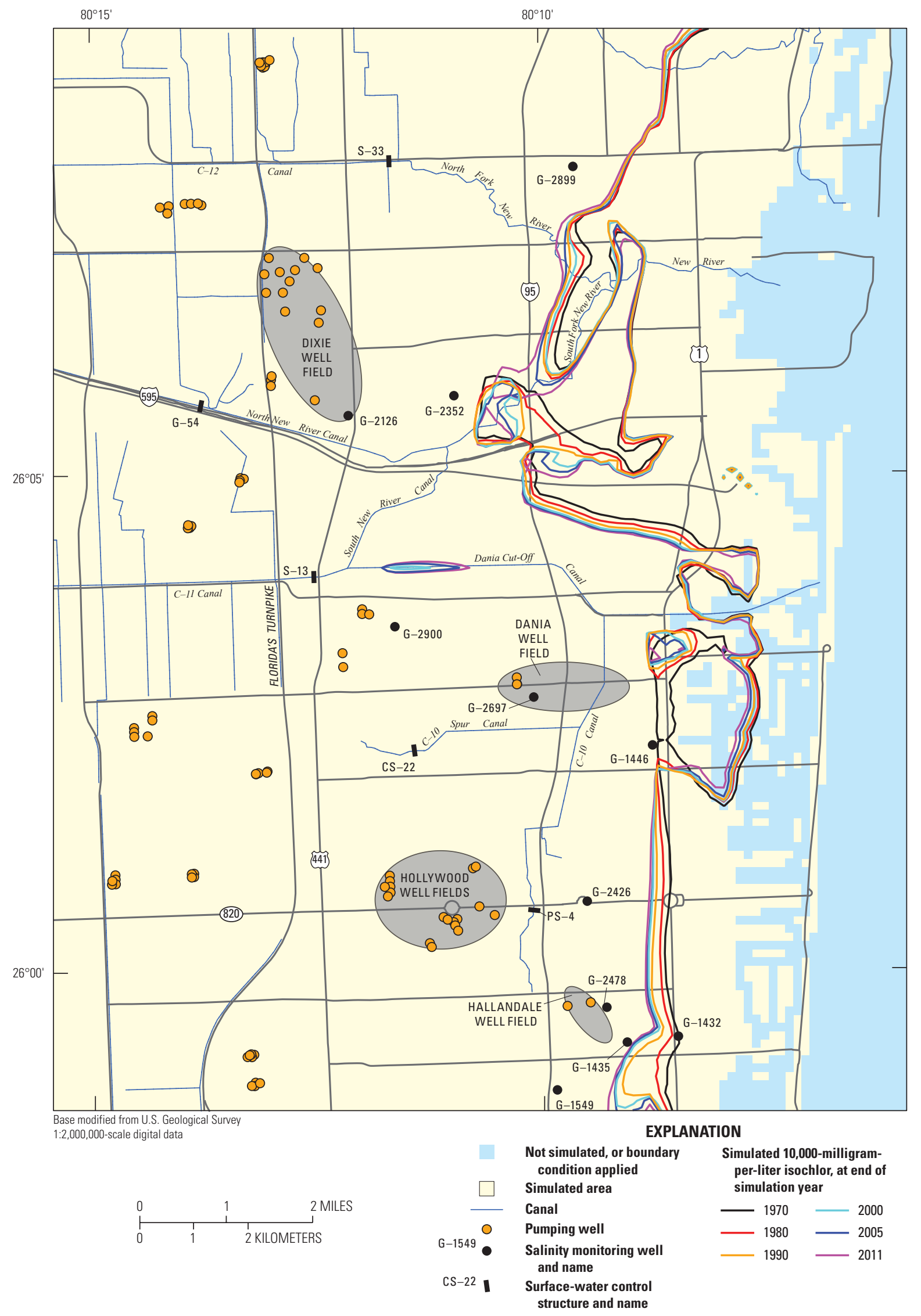

Figure 20. Simulated 10,000-milligram-per-liter isochlors at the end of 1970, 1980, 1990, 2000, 2005, and 2011. 


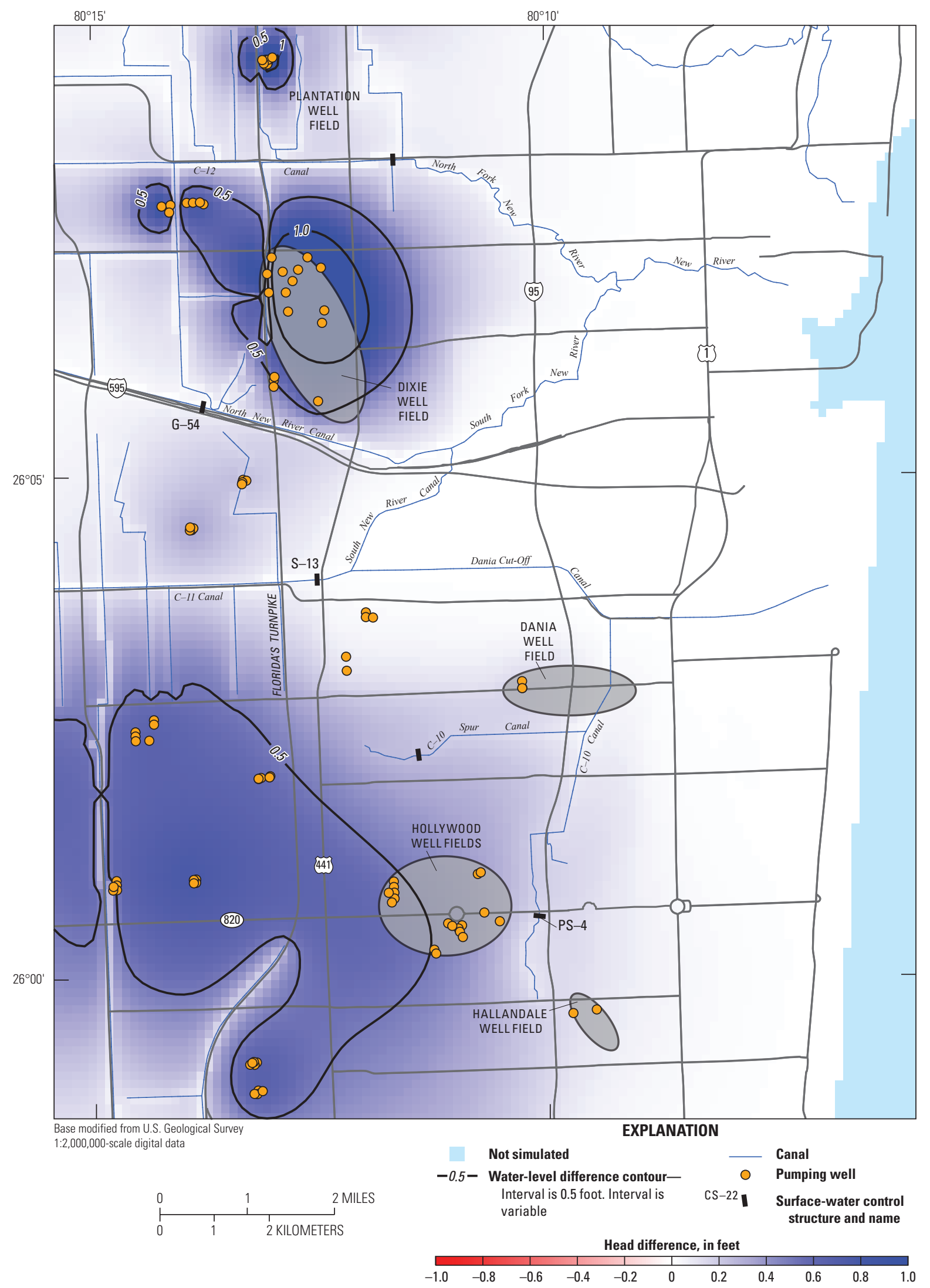

Figure 21. Difference in simulated groundwater levels in 2011 at the base of the Biscayne aquifer between Sensitivity Simulation 1 and the historical simulation. 


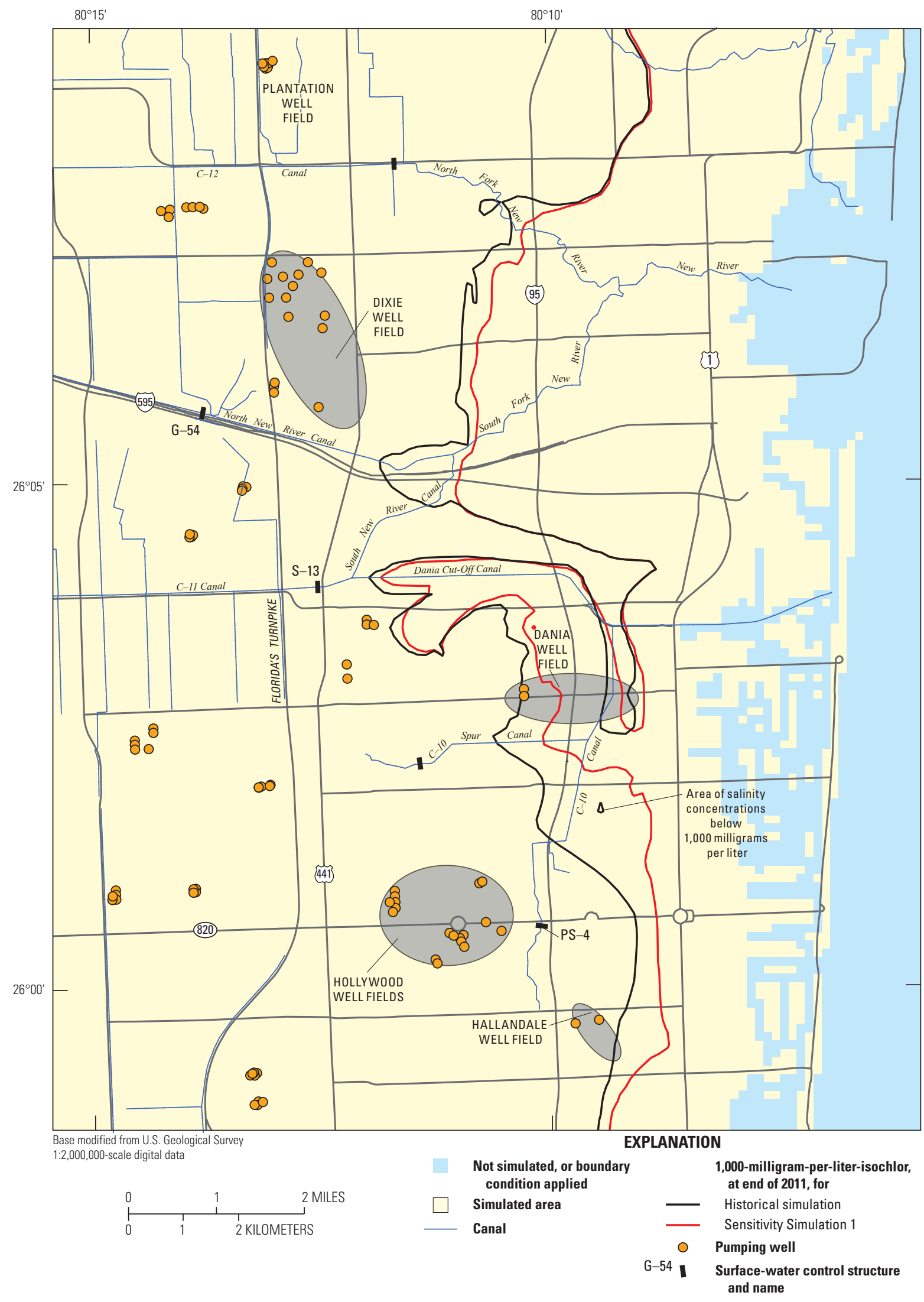

Figure 22. Simulated extent of the 1,000-milligram-per-liter isochlor in 2011 at the base of the Biscayne aquifer for Sensitivity Simulation 1 and the historical simulation. 
Table 1. Historical, sensitivity, and future scenario conditions.

[NRC, National Research Council]

\begin{tabular}{|c|c|c|c|}
\hline Simulation & Pumping distribution & Sea level & Other \\
\hline Historical & Monthly historical, 1950-2012 & Monthly historical, 1950-2012 & \\
\hline Sensitivity Simulation 1 & No pumping & Monthly historical, 1950-2012 & \\
\hline Sensitivity Simulation 3 & No pumping & Monthly tide, 1950 & \\
\hline Base Case Scenario & Permitted as of 2012 & $\begin{array}{l}\text { Simulated monthly tide for 1996-2011 meteorologic } \\
\text { period, no sea-level rise }\end{array}$ & \\
\hline Scenario 2 & Permitted as of 2012 & Simulated monthly tide, superimposed on NRC I & \\
\hline Scenario 3 & Permitted as of 2012 & Simulated monthly tide, superimposed on NRC II & \\
\hline Scenario 4 & Permitted as of 2012 & Simulated monthly tide, superimposed on NRC III & \\
\hline
\end{tabular}

\section{Sensitivity Simulation 2: Effects of Sea-Level Rise}

Results for Sensitivity Simulation 2 indicate that when historical sea-level rise is eliminated, the resulting groundwater levels are generally lower at the end of the simulation relative to the historical simulation (fig. 23). Water levels are as much as $0.5 \mathrm{ft}$ lower, particularly along and close to coastal creeks and canals east of the salinity control structures. In theory, the lateral hydraulic gradient in shallow aquifers is controlled by water-level elevations in recharge areas and sea level at the coast. For the historical simulation, as sea level rises, the lateral hydraulic gradient is reduced between onshore areas and the Atlantic Ocean, as well as within the coastal creeks and canals that are hydraulically connected to the Atlantic Ocean, resulting in a gradual increase in groundwater levels. Relative to the historical simulation, the hydraulic gradient near the coast in Sensitivity Simulation 2 is greater and resulting water levels at the end of the simulation are lower. This difference is accentuated near coastal creeks and canals, because canal stage below the salinity control structures is controlled by sea level, and canal stage controls local groundwater levels.

The extent of the $1,000-\mathrm{mg} / \mathrm{L}$ isochlor is generally similar or reduced in extent at the end of Sensitivity Simulation 2 relative to the historical simulation (fig. 24). In particular, elevated salinity is less extensive near the confluence of the North New River and the South New River canals, and along the Dania Cut-Off canal. In contrast, the parts of the isochlor that parallel the coast remained relatively unchanged. Sea level does not rise in Sensitivity Simulation 2, and as a result, the source of salinity in canals was reduced relative to the historical simulation, resulting in a relatively smaller extent of elevated salinity in areas where saltwater intrusion is largely controlled by downward leakage through canals. Another feature of Sensitivity Simulation 2 is the appearance of a body of freshwater east of the North New River canal, indicating that if sea level is low, there is greater freshwater recharge in that area.

\section{Sensitivity Simulation 3: Combined Effects of Pumping and Sea-Level Rise}

Results for Sensitivity Simulation 3 indicate that, with neither pumping nor historical sea-level rise, water levels at the end of the simulation are relatively higher in areas having well fields and relatively lower along coastal creeks and canals east of the salinity control structures, relative to the historical simulation (fig. 25). Between areas where Sensitivity Simulation 1 results in relatively higher water levels and areas where Sensitivity Simulation 2 results in relatively lower water levels, effects on water levels may negate one another, but the lateral hydraulic gradient may be larger. For example, groundwater levels for Sensitivity Simulation 3 are higher near the Dixie well-field area and lower along the North New River canal, relative to the historical simulation (fig. 25). Between Dixie well-field area and the North New River canal, the change in hydraulic gradient compared to the historical simulation is greater than the change in hydraulic gradient for either Sensitivity Simulation 1 (fig. 21) or Sensitivity Simulation 2 (fig. 23). In general, the onshore to offshore hydraulic gradient for Sensitivity Simulation 3 is greater than for either Sensitivity Simulations 1 or 2, indicating an increased flow of freshwater toward the coast and greater resistance to saltwater intrusion.

For Sensitivity Simulation 3, the position of the $1,000-\mathrm{mg} / \mathrm{L}$ isochlor (fig. 26) resembles a combination of those for Sensitivity Simulations 1 (fig. 22) and 2 (fig. 24). Notably, the reduction in Sensitivity Simulation 3 of the lobe of elevated salinity near the confluence of the North New River and South New River canals that occurs in the historical simulation is similar to that in the other Sensitivity Simulations, indicating the effects are not necessarily additive. South of the Hallandale well field, the reduction in extent of the intruded area in Sensitivity Simulation 3 is greater than the combined reduction in extent for Sensitivity Simulations 1 and 2. 


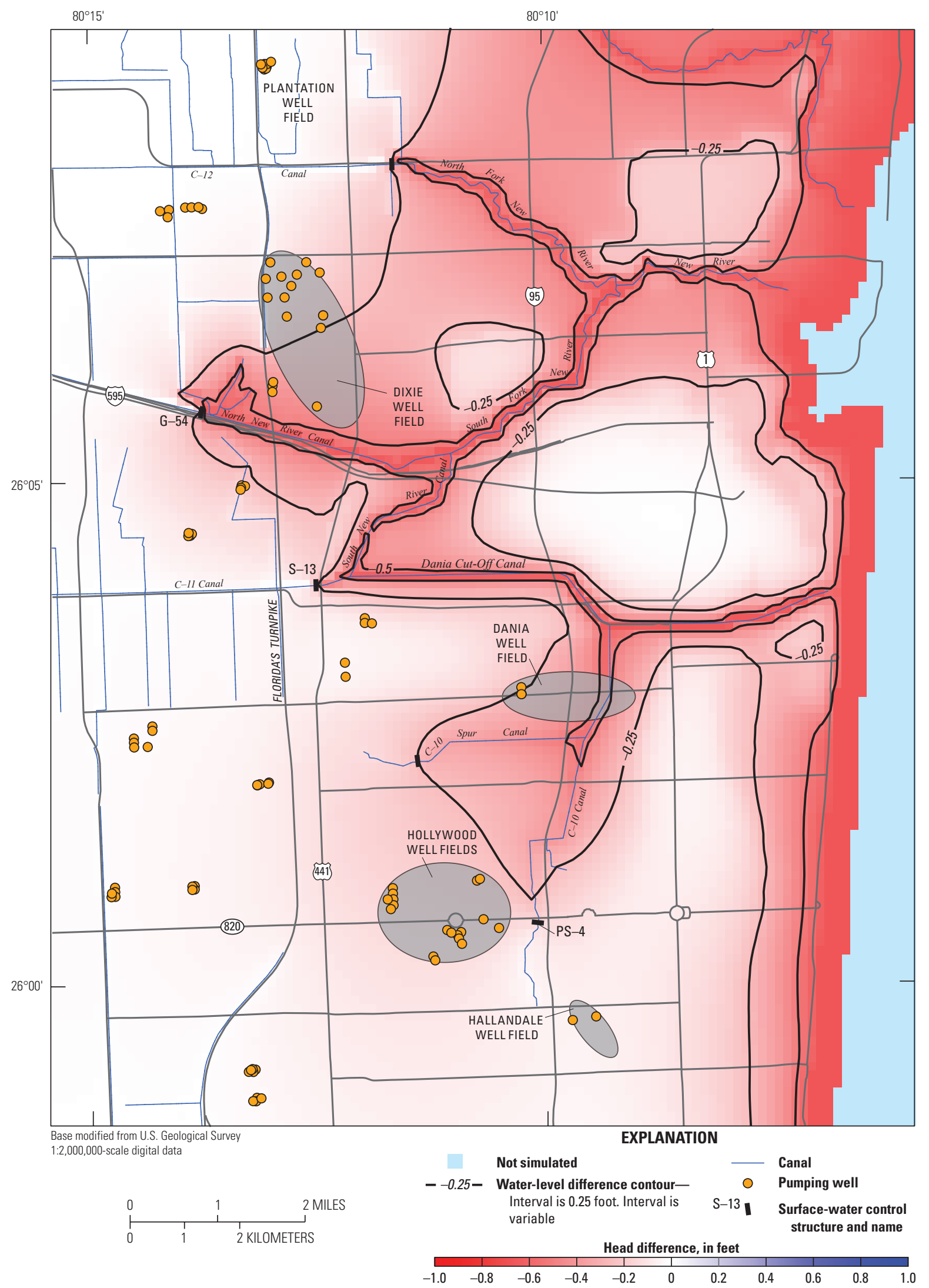

Figure 23. Difference in simulated groundwater levels in 2011 at the base of the Biscayne aquifer between Sensitivity Simulation 2 and the historical simulation. 


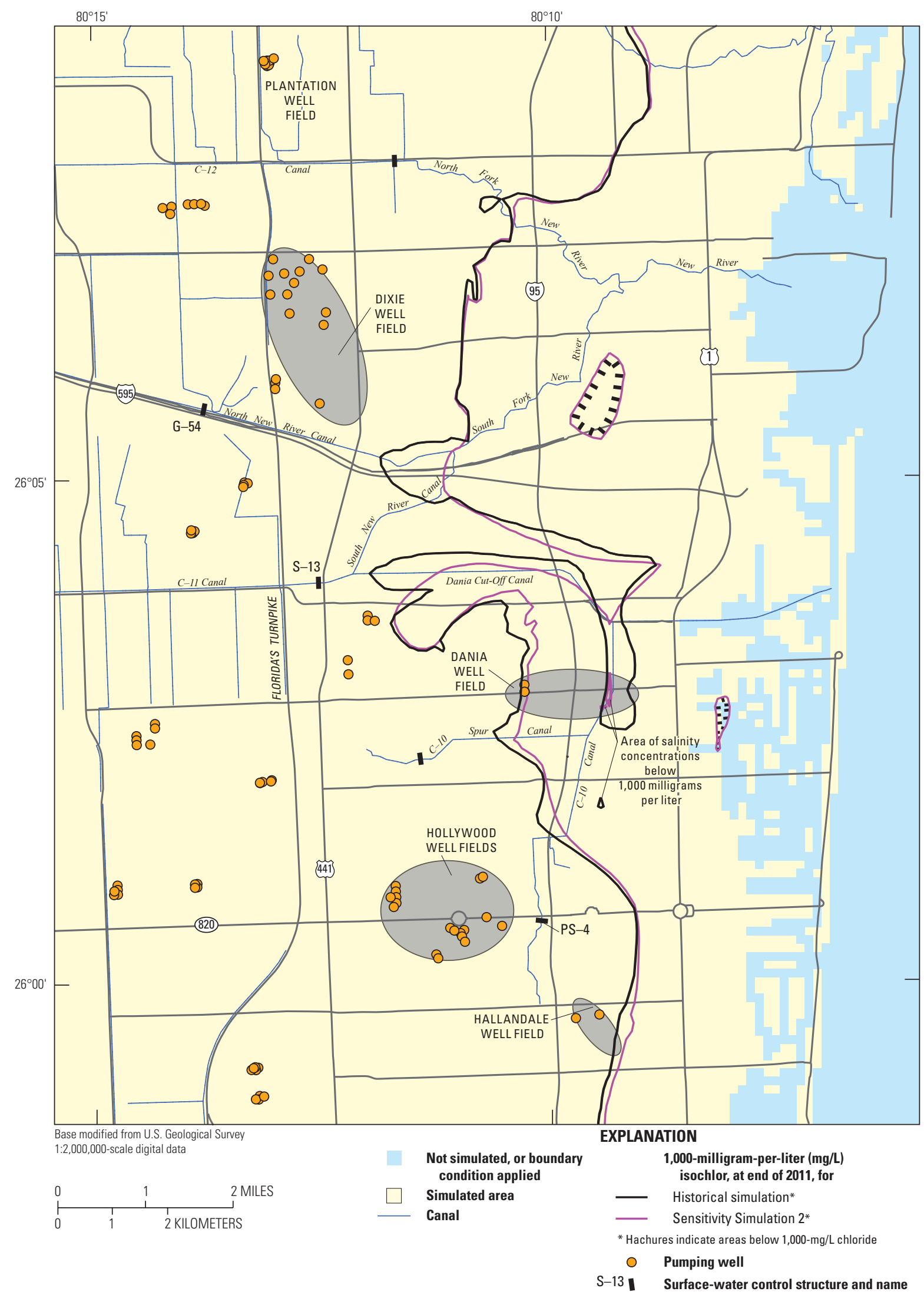

Figure 24. Simulated extent of the 1,000-milligram-per-liter isochlor in 2011 at the base of the Biscayne aquifer for Sensitivity Simulation 2 and the historical simulation. 


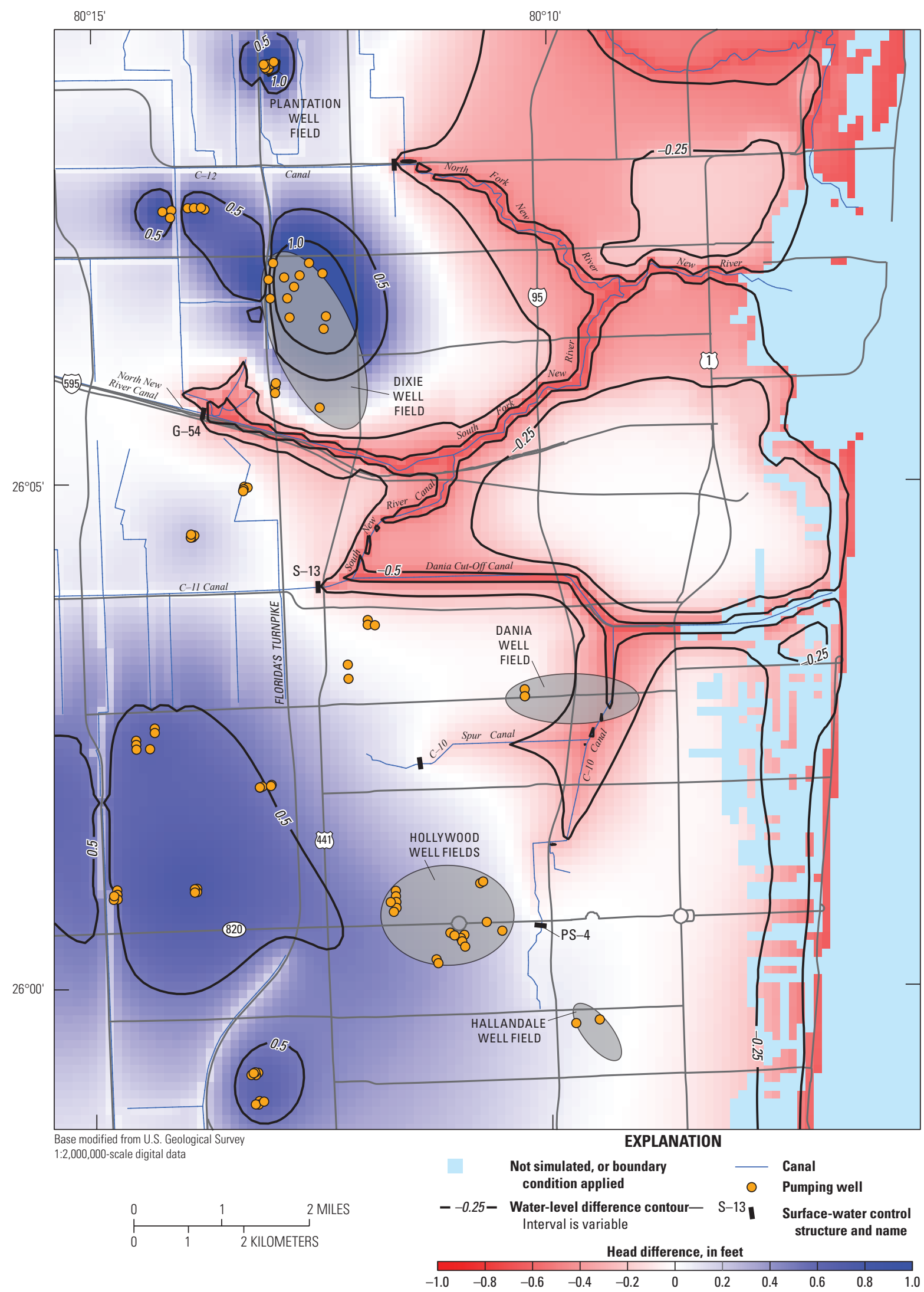

Figure 25. Difference in simulated groundwater levels in 2011 at the base of the Biscayne aquifer between Sensitivity Simulation 3 and the historical simulation. 


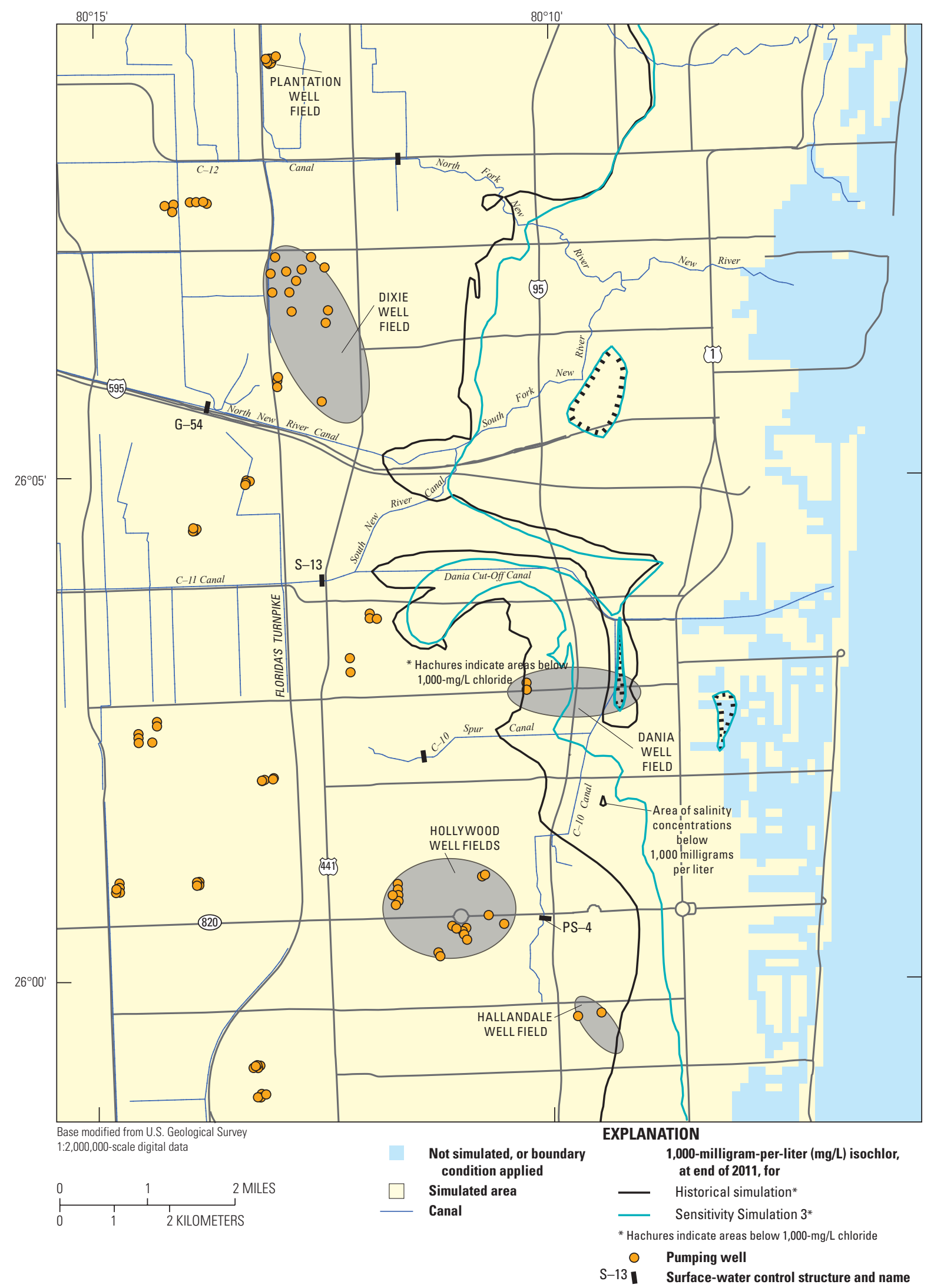

Figure 26. Simulated extent of the 1,000-milligram-per-liter isochlor in 2011 at the base of the Biscayne aquifer for Sensitivity Simulation 3 and the historical simulation. 


\section{Potential Effects of Predicted and Proposed Changes to the Hydrologic System on the Salinity Distribution in the Biscayne Aquifer}

The model was used to simulate the effects of alterations to the hydrologic system on the distribution of salinity in the Biscayne aquifer for a variety of future scenarios (table 1). Of particular concern are the effects of sea-level rise and changes in pumping distribution on salinity near production well fields. Strategies to mitigate increased saltwater intrusion could include movement of key surface-water salinity-control structures or use of recharge wells. To provide a baseline for comparison of future hypothetical conditions, a Base Case Scenario was constructed to simulate conditions from 2012 to 2062. For the Base Case and all other scenarios, meteorological conditions during 1996 to 2011 (fig. 27) were simulated on a repeating basis until the end of the simulation. These conditions were chosen because the data are considered to be the most accurate and consistent data available. The average annual rainfall deviations for the 1950-2012 study period, as well as for 1981-2010, indicate that the conditions during the 16-year period selected for the Base Case Scenario are drier than average. The pumping distribution for the Base Case Scenario was the permitted pumping (table 2). Independent of sea level, for the base case and all scenarios, salinity upstream of salinity-control structures is that of freshwater, and salinity downstream of salinity-control structures is that of seawater.

The sea level for the Base Case Scenario represents no long-term change in sea level after 2012. To simulate natural tidal variability, a synthetic tide was constructed. To create the synthetic tides, hourly "predicted" tidal data for the 1996-2025 period were generated using the NTP4 program developed by the National Ocean Service (Zetler, 1982) and harmonic constituents for the Virginia Key tidal gage. "Predicted" tides were not calculated after 2025 because annual constants are not available after 2025 using the NTP4 program. Monthly "predicted" tides (fig. 28) were calculated from the hourly "predicted" tides by averaging all of the tidal data for a given month for the 1996-2025 period. For example, the "predicted" tide for January was calculated by averaging all of the hourly tidal data in each January for each year between 1996 and 2025.

The observed tidal data for the period from 1996 through 2011 were subtracted from the predicted tidal data to generate a 16-year weather component signal (fig. 28). The weather component accounts for any tidal variability not accounted for by the "predicted" tide (for example, storm effects). An average weather component was calculated for each month between 1995 and 2011. To create tidal levels for the
Table 2. Pumping distributions by composite well field for 2007-11 and all scenarios.

[Values rounded to the nearest 0.1 million gallons per day (Mgal/d). Underlined values indicate permitted values that are substantially (more than $0.1 \mathrm{Mgal} / \mathrm{d}$ ) less than actual values during 2007-11. Bold values indicate permitted values that are larger than actual values during 2007-11. Data sources: Francois Domond (City of Hollywood, written commun., May 2, 2014); Larry Teich (City of Fort Lauderdale, written commun., June 3, 2014); Tim Welch (City of Sunrise, written commun., June 24, 2014); Mike Zygnerski (Broward County, written commun., April 25 and June 24, 2014)]

\begin{tabular}{|c|c|c|c|}
\hline Composite well field & $\begin{array}{c}2007-11 \\
\text { actual }\end{array}$ & $\begin{array}{l}\text { Scenario } 1 \\
\text { (modified } \\
\text { historical) }\end{array}$ & $\begin{array}{l}\text { Base Case } \\
\text { (permitted) } \\
\text { and all other } \\
\text { scenarios }\end{array}$ \\
\hline & \multicolumn{3}{|c|}{ Mgal/d } \\
\hline Broward (System 1A) & 7.9 & 7.9 & 9.2 \\
\hline Broward South Regional & 11.2 & 11.2 & 14.2 \\
\hline Cooper City & 3.7 & 3.7 & 4.6 \\
\hline Coral Springs & 8.4 & 8.4 & 9.4 \\
\hline Coral Springs ID & 5.0 & 5.0 & 5.4 \\
\hline Dania Beach & 1.2 & 1.1 & 1.1 \\
\hline Davie & 9.0 & $\underline{5.0}$ & 5.0 \\
\hline Ferncrest Utilities & 0.7 & 0.7 & 0.7 \\
\hline Fort Lauderdale (Prospect) & 34.3 & 34.3 & 43.4 \\
\hline Fort Lauderdale (Dixie) & 17.1 & $\underline{15.0}$ & 15 \\
\hline Hallandale Beach & 2.7 & 2.7 & 2.7 \\
\hline Hollywood (Chaminade) & 11.1 & 11.1 & 15 \\
\hline Hollywood (South) & 7.6 & 7.6 & 9.8 \\
\hline Lauderhill & 5.7 & 5.7 & 7.7 \\
\hline Margate & 7.9 & 7.9 & 8.5 \\
\hline Miramar & 13.0 & 13.0 & 13.3 \\
\hline North Lauderdale & 2.6 & 2.6 & 3.2 \\
\hline Pembroke Pines & 12.8 & 12.8 & 15.6 \\
\hline Plantation & 14.0 & 14.0 & 17.2 \\
\hline Pompano Beach & 15.1 & 15.1 & 17.8 \\
\hline Royal Utility Company & 0.4 & 0.4 & 0.5 \\
\hline Sunrise (Flamingo Park) & 10.7 & 10.74 & 11.3 \\
\hline Sunrise (Sawgrass) & 6.9 & $\underline{6.0}$ & 6 \\
\hline Sunrise (Southwest) & 1.1 & 1.1 & 1.1 \\
\hline Sunrise (Springtree) & 12.8 & $\underline{10.7}$ & 10.7 \\
\hline Tamarac & 6.0 & 6.0 & 7.2 \\
\hline Total & 228.9 & 219.74 & 255.58 \\
\hline
\end{tabular}



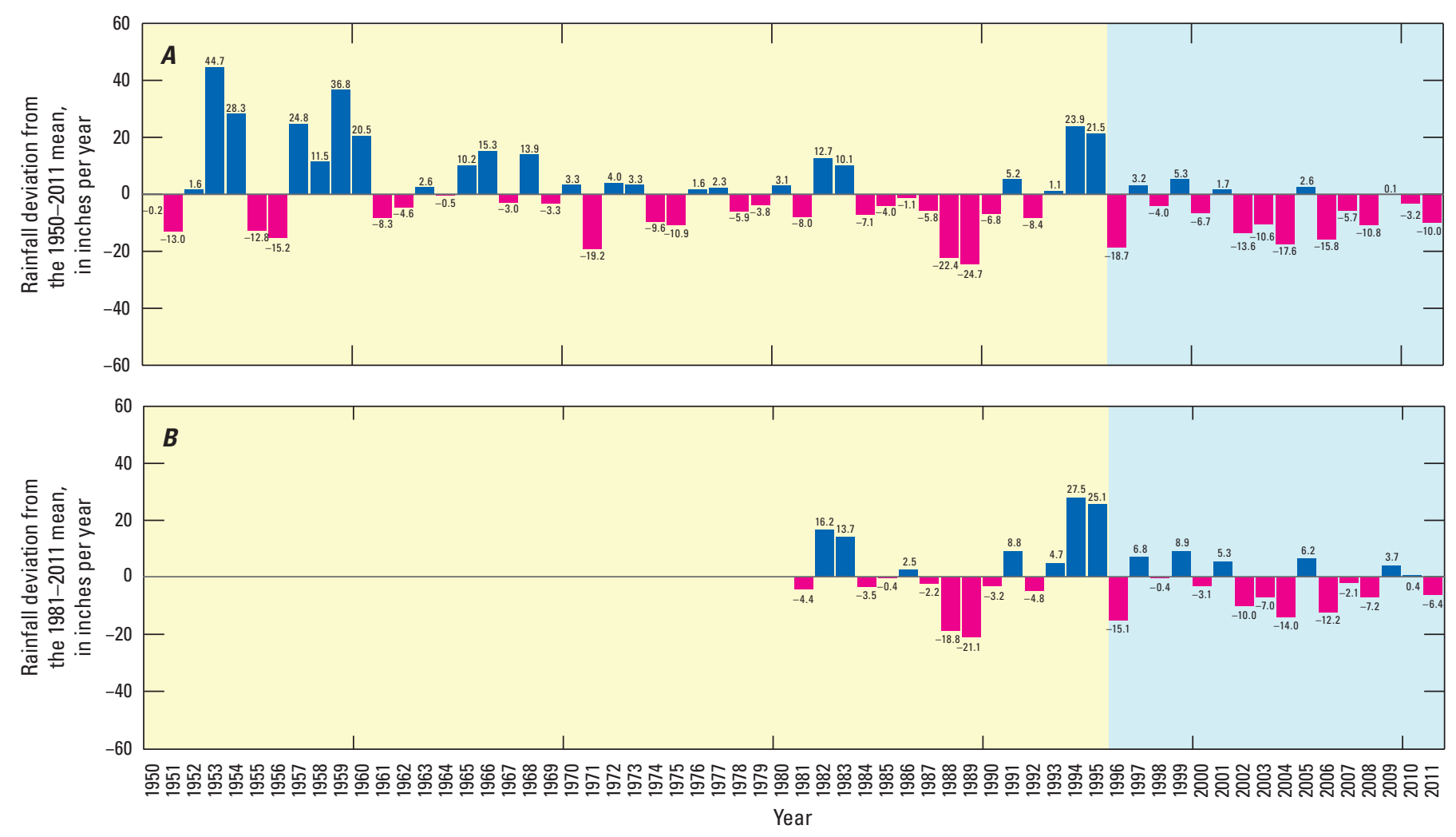

Figure 27. Deviations from $A$, mean annual rainfall during 1950-2011 and $B$, mean annual rainfall during 1981-2011 (NEXRAD [Skinner and others, 2009] and National Oceanic and Atmospheric Administration data [South Florida Water Management District, 2012], appendix 1). Light blue shading indicates the 16-year meteorological conditions used for the future scenarios.

Base Case future conditions, the monthly average "predicted" tide for 2012 was repeated consecutively for 16 years. Then, the 1995-2011 monthly average weather component was added to the 16-year "predicted" tide to create synthetic tidal data. The 16-year synthetic tidal data were repeated 3.125 times to create synthetic tidal data for the 50-year scenario simulation period (fig. 28).

Results of the Base Case simulation indicate that the extent of elevated salinity retreats seaward in most areas, but advances landward in some areas (fig. 29), relative to initial conditions at the end of the historical simulation. The simulated 1,000-mg/L isochlor during 2060 advanced slightly beyond the 2011 simulated extent east and south of Hollywood well-field area (fig. 29). Between the Hollywood well-field area and the Dania Cut-Off canal, the extent of elevated salinity retreats seaward from the position of the 2011 simulated extent. Permitted pumping increases for two Hollywood well fields and decreases for the Dania, Davie, and Dixie well fields (table 2). North of the Dania Cut-Off canal, the predicted extent of elevated salinity remains close to its location in 2011, except along the North New River canal, where the Base Case extent of salinity has retreated seaward. Most of the well-field pumping in the northern part of the model is located farther away from the area of intrusion than in the central or southern parts of the model area.

Simulated, flow-weighted, average chloride concentrations indicate a slight, gradual increase for the Base Case Scenario at Hallandale well field (fig. 30) and a gradual decrease at Dania well field. Flow-weighted average chloride concentrations at all other well fields are near zero or very small. These values represent the chloride concentration of water discharged at a given well field. Seasonal and climatic variability are superimposed on the general changes in salinity. Variability on a yearly basis is due to monthly pumping variability, because the pumping is on a 1-year cycle. The chloride concentration time series at Hallandale well field shows a distinct yearly signature. Variability on a longer basis is due to variability in the 16-year meteorological and tidal cycles. Chloride concentration at the Dania well field shows a slight annual variability and a distinct 16-year signature. During periods of repeated drier than average years, such as years $7-13$, the increase in salinity is pronounced, and during periods of repeated wet years, such as years 14-22, the salinity declines. These results indicate that climatic conditions could reduce or augment effects of pumping on saltwater intrusion, depending on location and rate of pumping relative to recharge. 

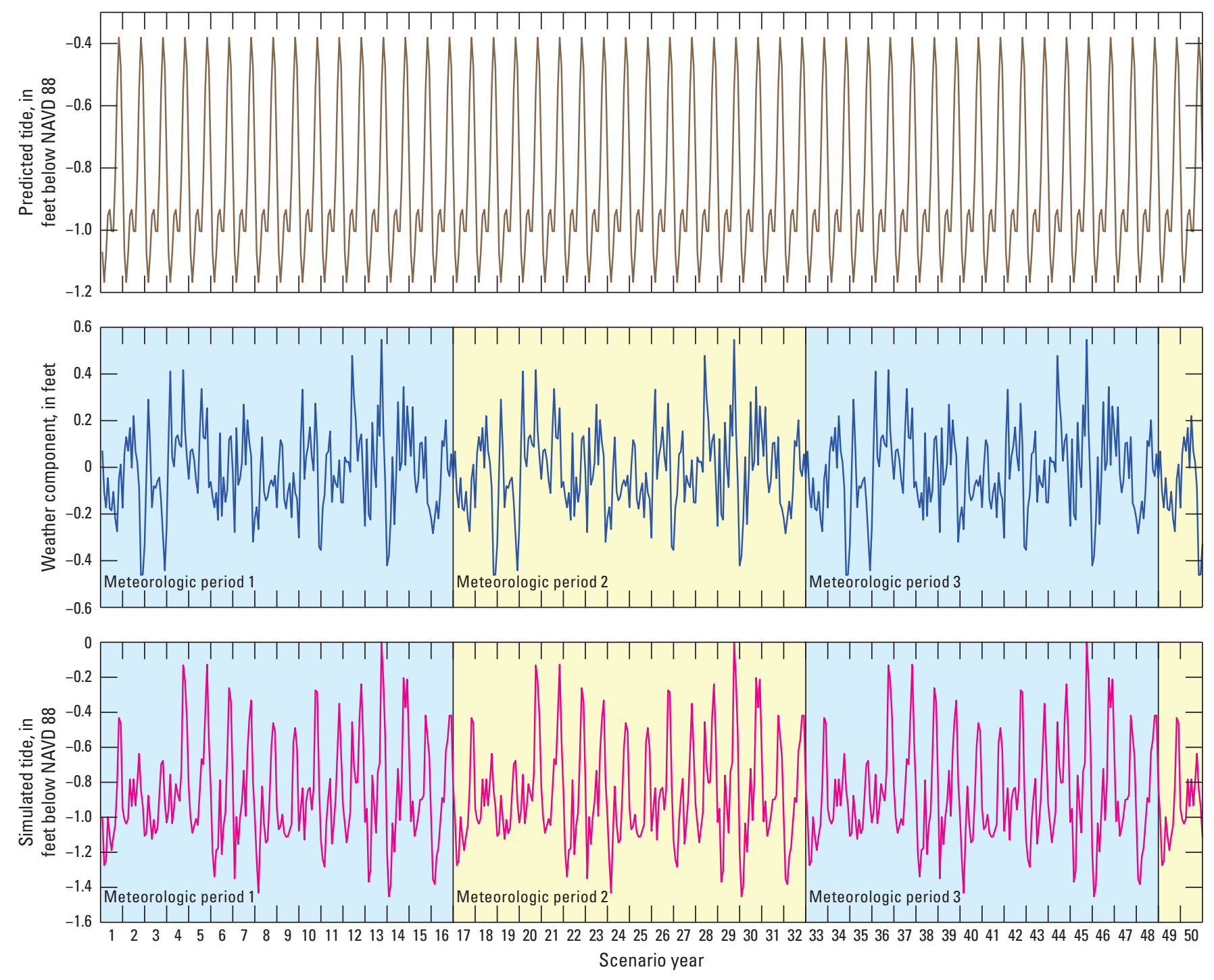

Figure 28. Predicted tide, weather component of tide, and synthetic tide generated for Base Case Scenario. 


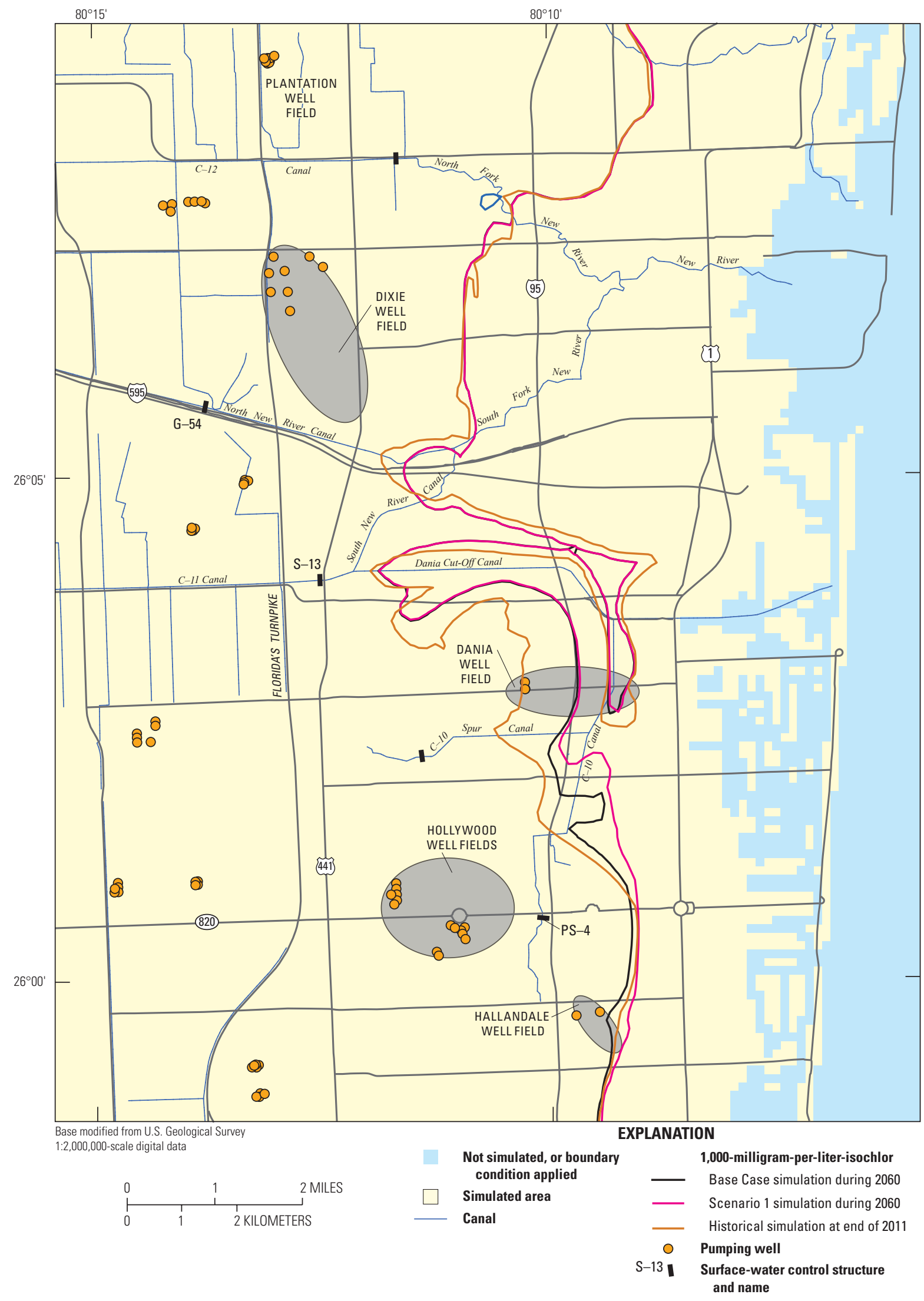

Figure 29. Simulated extent of the 1,000-milligram-per-liter isochlors during 2011 at the end of the historical simulation, and during 2060 for the Base Case Scenario and Scenario 1. 


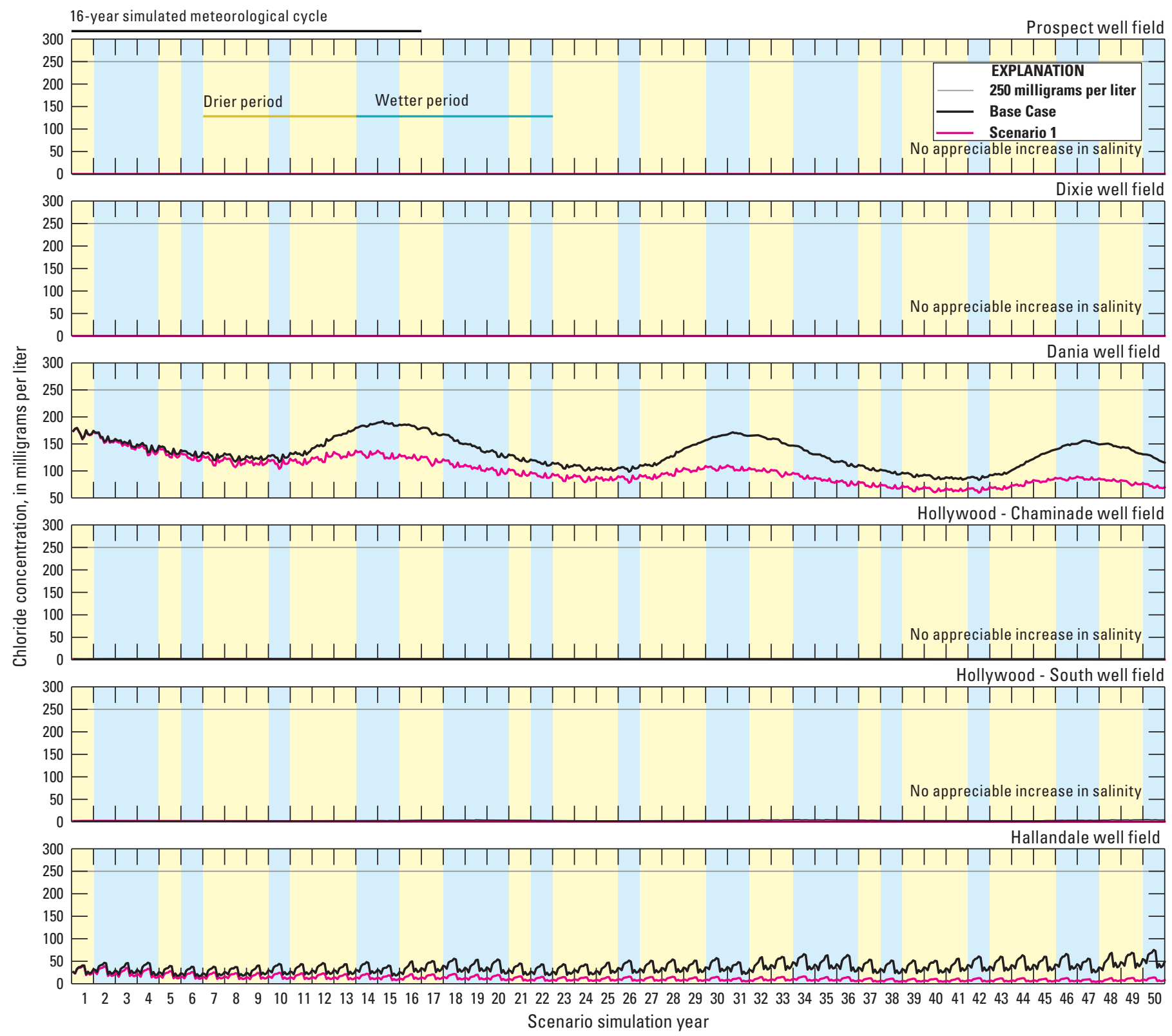

Figure 30. Simulated, flow-weighted, average chloride concentration at select well fields for the Base Case Scenario and Scenario 1. Yellow shading indicates drier than average climatic periods, and blue shading indicates wetter climatic periods, as shown by deviations from average rainfall in figure 27. 


\section{Effects of Maintaining Historical Groundwater Pumping Rates on Salinity Distribution}

Scenario 1 is designed to test the effects of maintaining a lower pumping rate than permitted on salinity distribution (table 2). For Scenario 1, the pumping is modified from the average monthly pumping rate during 2007-11 (fig. 31A). During this period, average monthly pumping was reduced relative to preceding years in response to pumping restrictions imposed in 2007 (South Florida Water Management District, 2009) and was thus selected as the period most representative of near-term expected conditions. The pumping distribution for Scenario 1 was modified by (1) reducing any pumping that exceeded permitted values during 2007-11 to the permitted rates and (2) removing selected wells and well fields that have since been abandoned and redistributing pumping to the remaining well fields and wells (table 2). This scenario effectively represents maintenance of actual pumping rates relative to permitted or historical rates. All other model input is the same as for the Base Case Scenario. The permitted annual pumping rate for each well field was distributed monthly according to the monthly proportional distribution of the Base Case Scenario pumping (fig. $31 B$ ). The resulting monthly pumping rate for each well field was distributed among active wells using historical proportions for active scenario wells.

This pumping distribution was repeated consecutively for each scenario year.

Results of Scenario 1 simulation indicate the inland extent of the $1,000-\mathrm{mg} / \mathrm{L}$ isochlor in 2060 is seaward relative to that of the Base Case Scenario from the Dania well-field area southward and has essentially the same inland extent north of the Dania well-field area (fig. 29). The reductions in pumping relative to the Base Case are greatest for Prospect and combined Hollywood well fields (table 2). The results also show the simulated, 2060, 1,000-mg/L isochlor is similar in extent to the 2011 isochlor near Hallandale and east of the Hollywood well-field area. The pumping in Scenario 1 at these well fields is essentially the same as the actual pumping simulated for 2007-11. Pumping at Davie for Scenario 1 is reduced from the 2007-11 simulated pumping, which may result in the seaward retreat of elevated salinity between the C-10 spur and east of the Hollywood well-field area.

Simulated, flow-weighted, average chloride concentrations decline substantially in Scenario 1 at the Dania well field, as well as at the Hallandale well field, although the concentrations are already low (fig. 30). Yearly and climatic signals are visible on the chloride concentration trend, although subdued relative to the Base Case. Simulated flow-weighted average chloride concentrations at all other well fields are near zero.

\section{Effects of Predicted Sea-Level Rise on Salinity Distribution}

The effects of variable rates of sea-level rise on salinity distribution are tested in Scenarios 2, 3, and 4, which incorporate the modified National Research Council (NRC) rates of sea-level rise as described by the U.S. Army Corps of Engineers (2009). These rates correspond to the sea-level rise projections selected by the Southeast Florida Regional Climate Change Compact Technical Ad hoc Work Group (2011) for use in understanding regional vulnerabilities to sea-level rise, and planning adaptation strategies. Modified NRC sea-level rise rates I, II, and III are quadratic functions that reflect increasing rates of sea-level rise and are ordered from lowest to highest predicted rates. The three rates of sea-level rise are applied in the model by superimposing the synthetic monthly tide (fig. 28) onto the modified NRC I, II, and III sea-level rise curves by adding the monthly offset for each modified NRC curve to the monthly synthetic tidal value (fig. 32). The total rise in sea level after 50 years for modified NRC sea-level rise rates I, II, and III, are $0.77,1.40$, and $2.03 \mathrm{ft}$, respectively.

Results of simulations 2, 3, and 4 show that for all three scenarios, the extent of elevated salinity mostly moves landward of the Base Case Scenarios by 2060 and that the extent is progressively farther landward at higher rates of sea-level

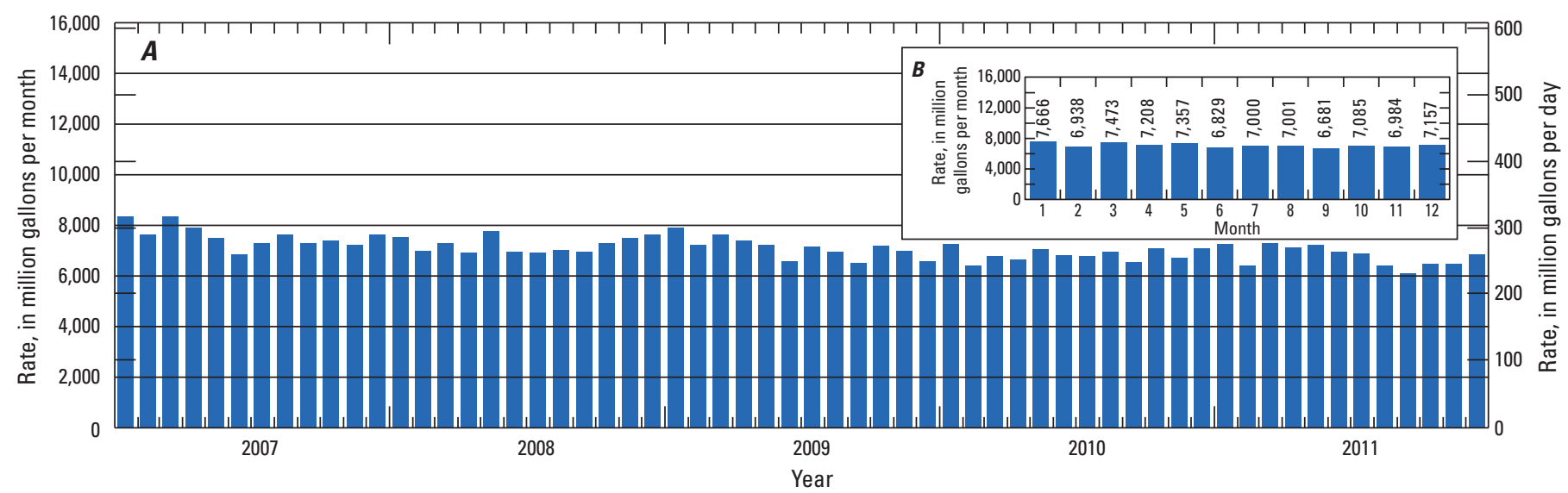

Figure 31. $A$, Average monthly pumping during 2007-11, and $B$, monthly pumping distribution for Scenario 1 . 


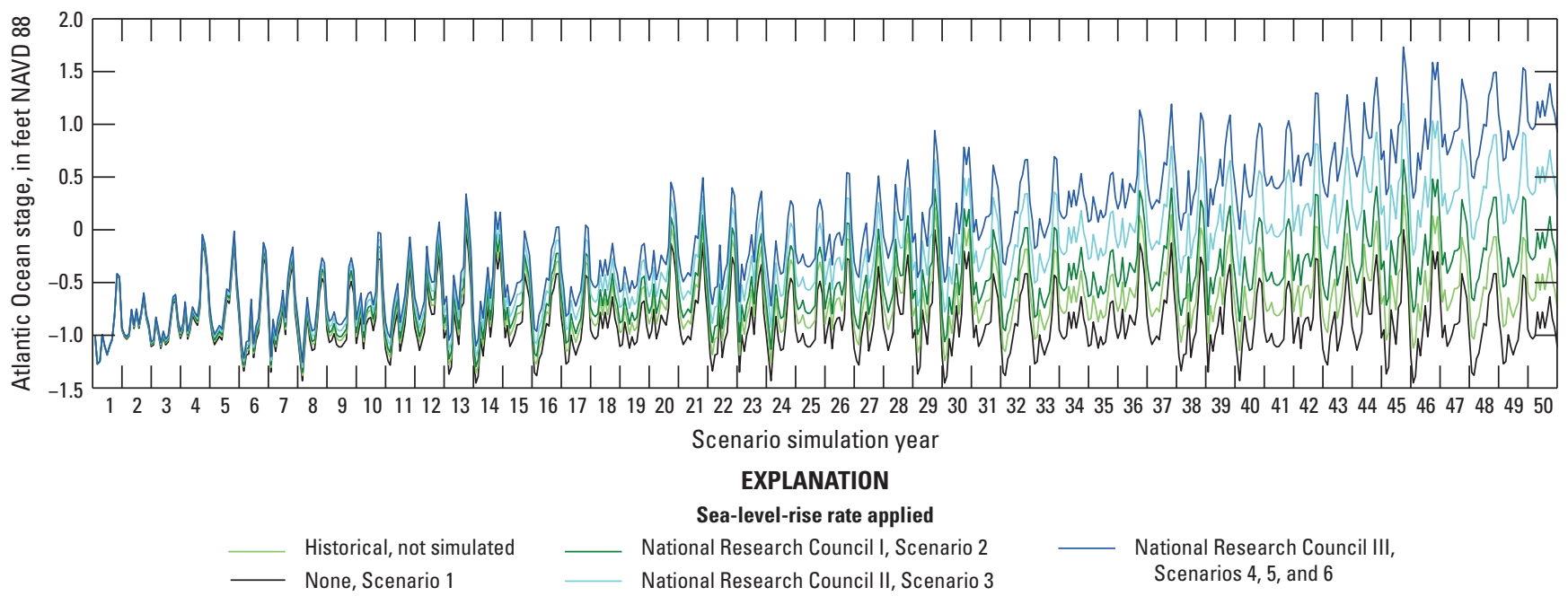

Figure 32. Monthly sea-level elevations applied to the scenarios.

rise (fig. 33). The greatest advances are along the North New River, Dania Cut-Off, C-11, and C-10 Spur canals. The extents of elevated salinity advance beyond control structures along the $\mathrm{C}-10$ canal at all three rates of sea-level rise, and beyond the $\mathrm{S}-13$ salinity-control structure on the $\mathrm{C}-11$ canal for the two highest rates of sea-level rise.

Simulated, flow-weighted average chloride concentrations increase above the Base Case concentrations with an increasing rate of sea-level rise at the Dania well field, both Hollywood well fields, and the Hallandale well field (fig. 34). Chloride concentration increases at the Dania well field are substantial for Scenarios 2, 3, and 4, and for Scenarios 3 and 4 at the Hallandale and Hollywood South well fields. Chloride concentrations simulated for the Hollywood Chaminade well field are lower in magnitude than for the Dania Hallandale, and Hollywood South well fields and surpass $250-\mathrm{mg} / \mathrm{L}$ by the end of the 50-year simulation period only for Scenario 4. Simulated chloride concentrations remain below $50 \mathrm{mg} / \mathrm{L}$ for Scenario 4 at other locations but start to increase at the Dixie well field by the end of the simulation period. Simulated chloride concentrations at the Prospect well field are near zero. The annual pumping variability signal and 16-year synthetic tidal signals are visible, particularly for the Dania and Hallandale well-field concentrations.

\section{Effects of Movement of the G-54 Salinity-Control Structure on Salinity Distribution}

Scenario 5 tests the effects of moving a salinity control structure eastward toward the coast, with the highest simulated sea-level rise rate, as simulated in Scenario 4. The G-54 salinity-control structure is located in the North New River canal, east of State Road 817 (also known as University Drive) and west of Florida's Turnpike (fig. 35). The structure is positioned to allow deep-water passage westward toward the center of the county, and to provide freshwater recharge for salinity control to the west upstream of the structure. Downward leakage through canals that are not protected from saltwater incursion by salinity control structures is a major pathway of salinity into the Biscayne aquifer in some areas, such as central coastal Broward County. In theory, moving the salinity control structure to the east could protect more of the aquifer from downward leakage of saltwater through the canals. The proposed location is upstream of the confluence of the North New River and South New River canals, so it would also have a minimal effect on freshwater and saltwater wetlands downstream and along the South Fork New River. Hypothetically, the G-54 structure could be moved 2.5 miles downstream to a location east of U.S. 441 and west of the confluence of the North New River and South New River canals (fig. 35). Scenario 5 simulates the potential effects of this hypothetical movement of the $\mathrm{G}-54$ structure, with a high rate of sea-level rise, on the salinity distribution (table 1).

Results of Scenario 5 show that by the end of the 50-year simulation period, the extent of elevated salinity does not advance beyond the new location of the G-54 salinity control structure (fig. 36). Compared with the results from Scenario 4, the extent is not as far west near the North New River canal, but in all other locations, the extent is essentially the same. Relative to the Base Case results, the extent of elevated salinity for Scenario 5 is farther inland, from north of the confluence of the North New River and South New River canals, to the Hallandale well-field area. These results indicate that moving the G-54 structure could counteract effects of sea-level rise locally.

Simulated, flow-weighted average chloride concentrations at the well fields for Scenario 5 are essentially the same as for Scenario 4 except at Dixie well field (fig. 37). Toward the end of the 50-year simulation period, concentrations at this well field increase in Scenario 4 and remain near zero in Scenario 5. 


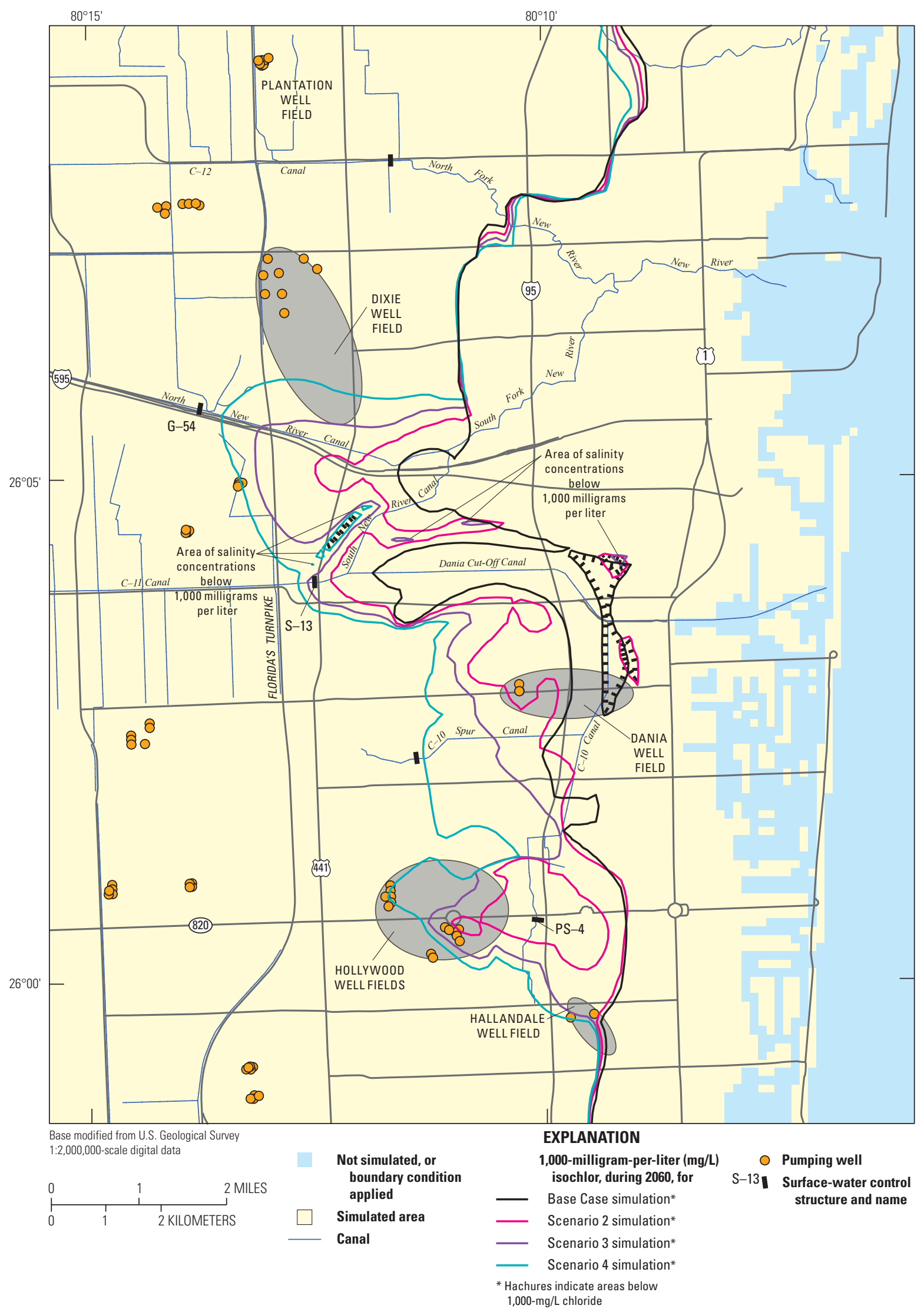

Figure 33. Simulated extent of the 1,000-milligram-per-liter isochlors for the Base Case, and Scenarios 2, 3, and 4 during 2060. 
6 -year simulated meteorological cycle

Prospect well field

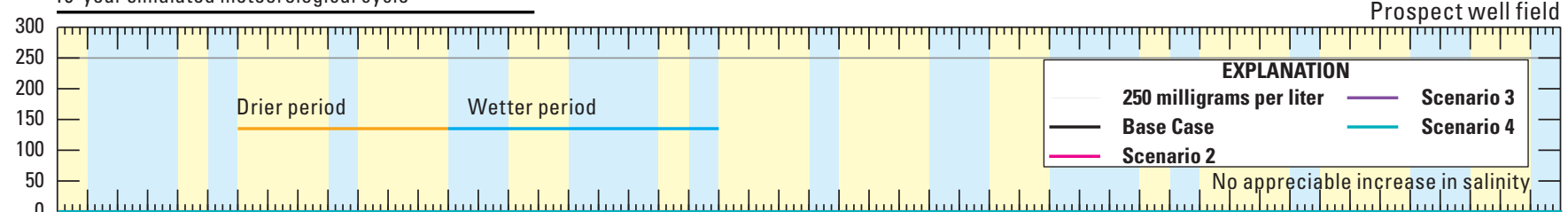

Dixie well field

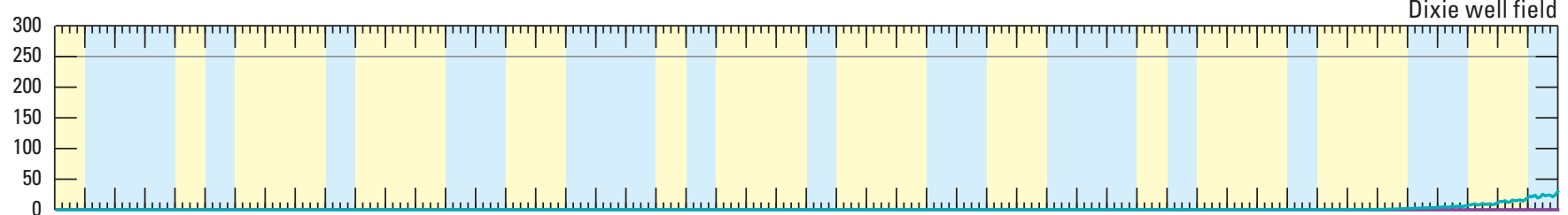

Dania well field
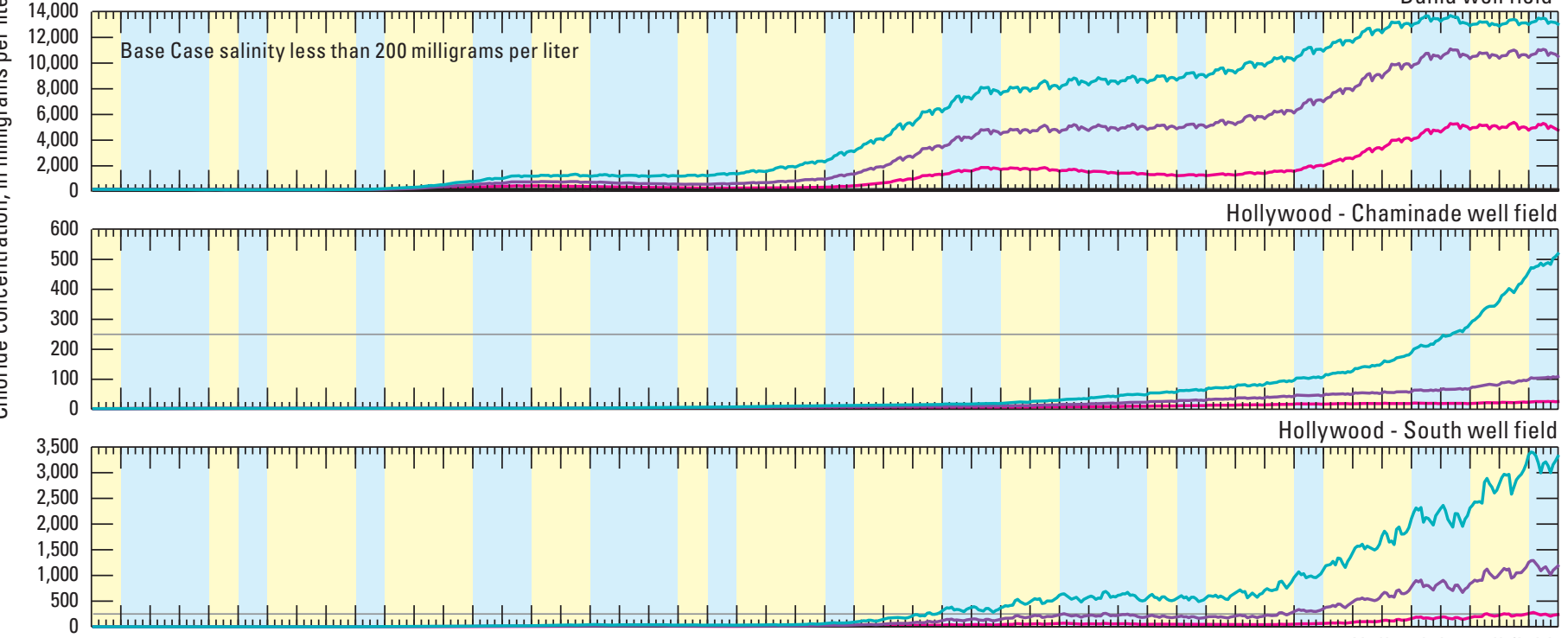

Hallandale well field

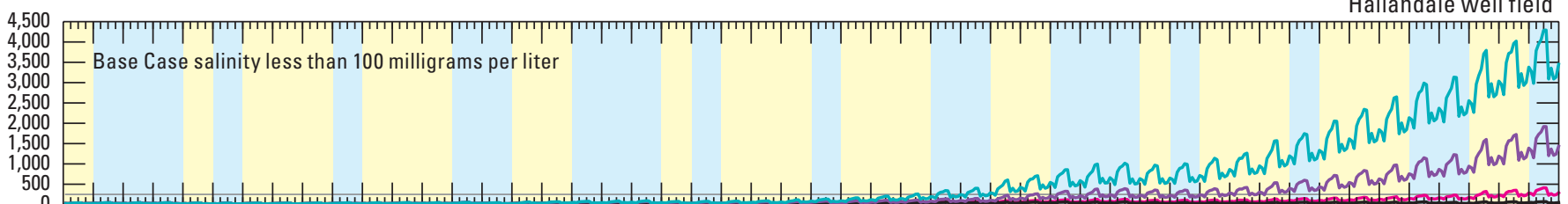

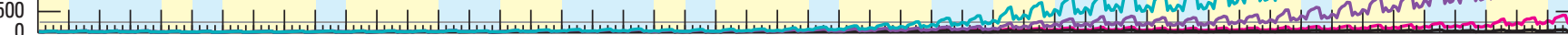

$122 \quad 3 \quad 4 \quad 5 \quad 6 \quad 7 \quad 8 \quad 91011121314151617181920212223242526272829303132333435363738394041424344454647484950$ Scenario simulation year

Figure 34. Graphs showing simulated, flow-weighted, average chloride concentrations at select well fields for the Base Case, and Scenarios 2, 3, and 4. Yellow shading indicates drier than average climatic periods, and blue shading indicates wetter climatic periods, as shown in figure 27. 


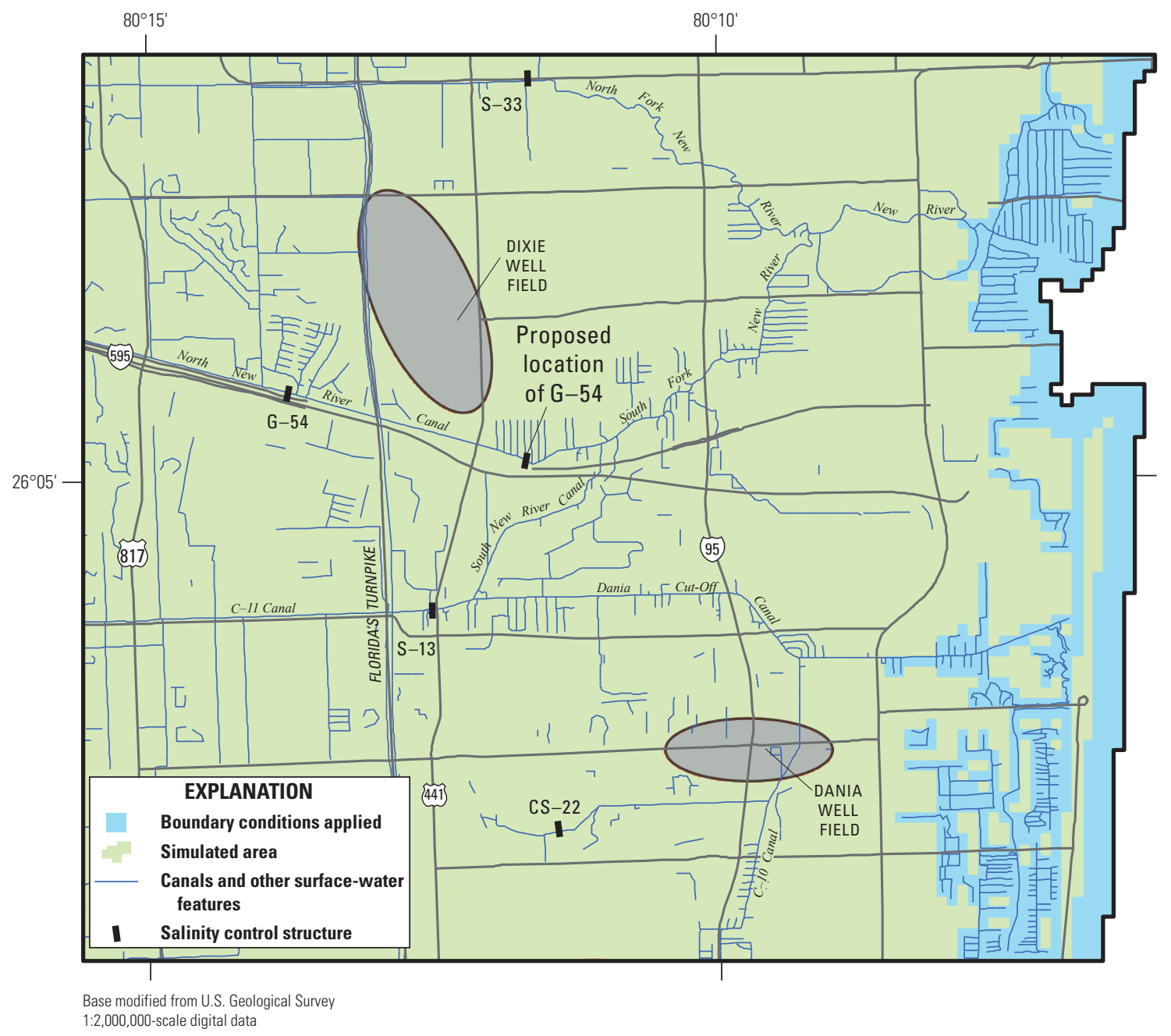

Figure 35. Current and proposed location of the G-54 salinity-control structure. 


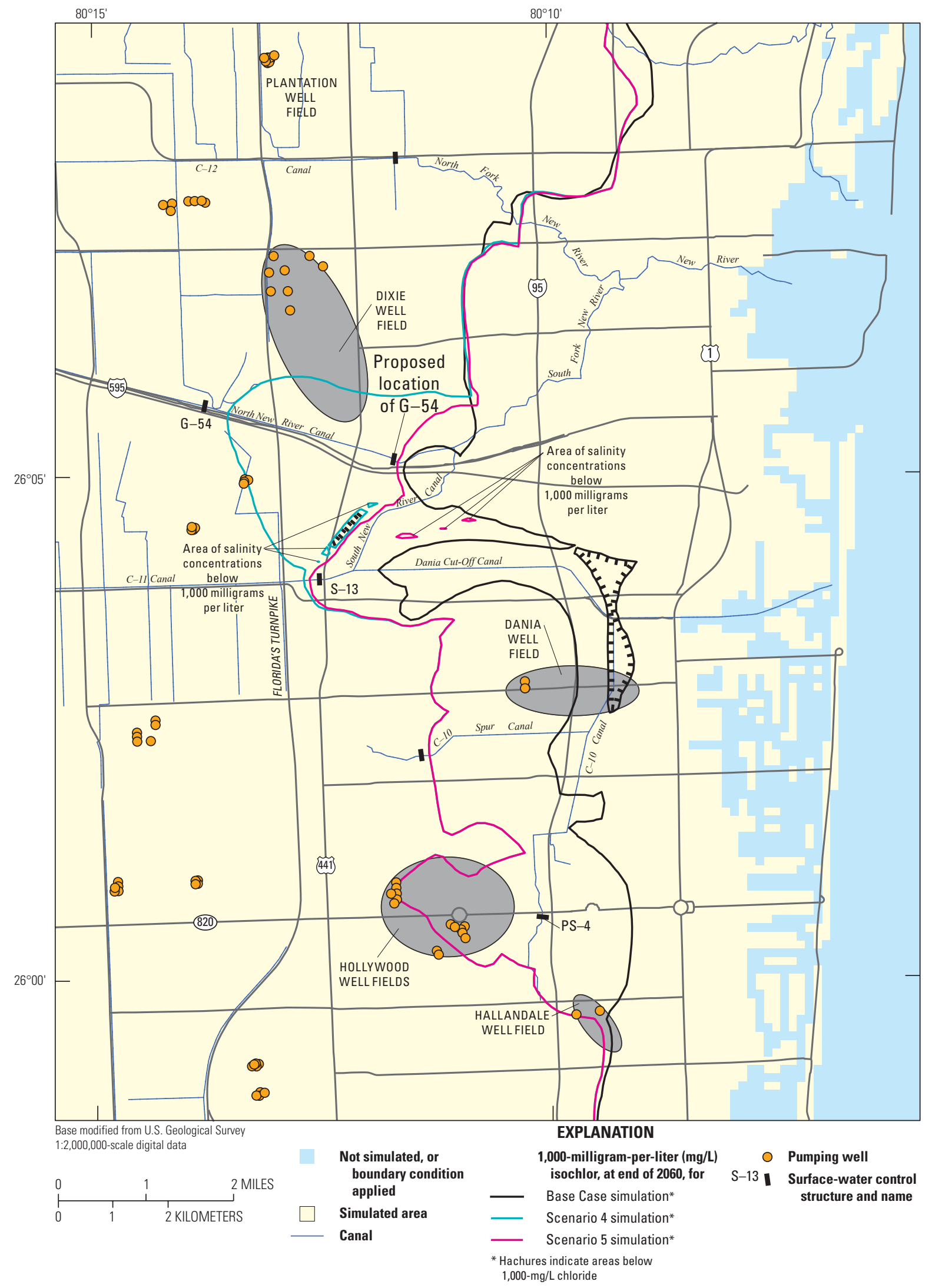

Figure 36. Simulated extent of the 1,000-milligram-per-liter isochlors for the Base Case, and Scenarios 4 and 5 during 2060. 
16-year simulated meteorological cycle

Prospect well field

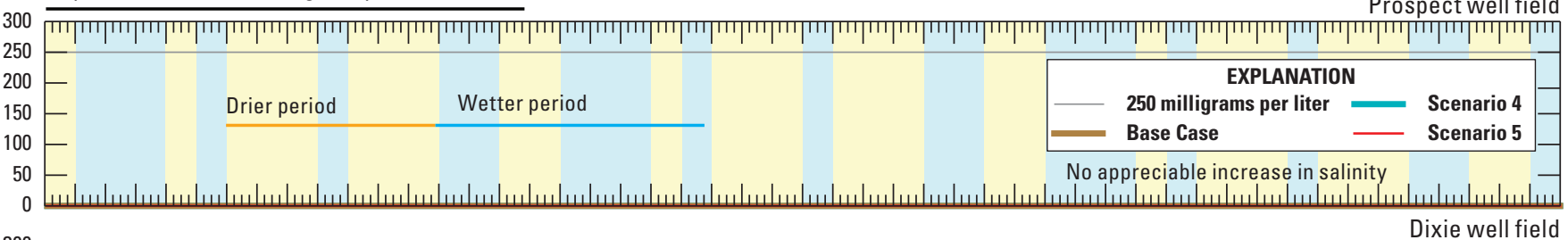

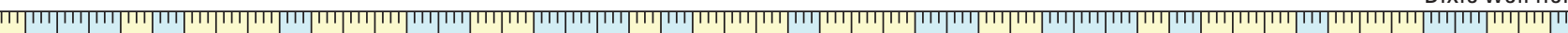

-

50

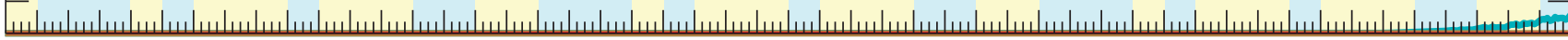
Dania well field

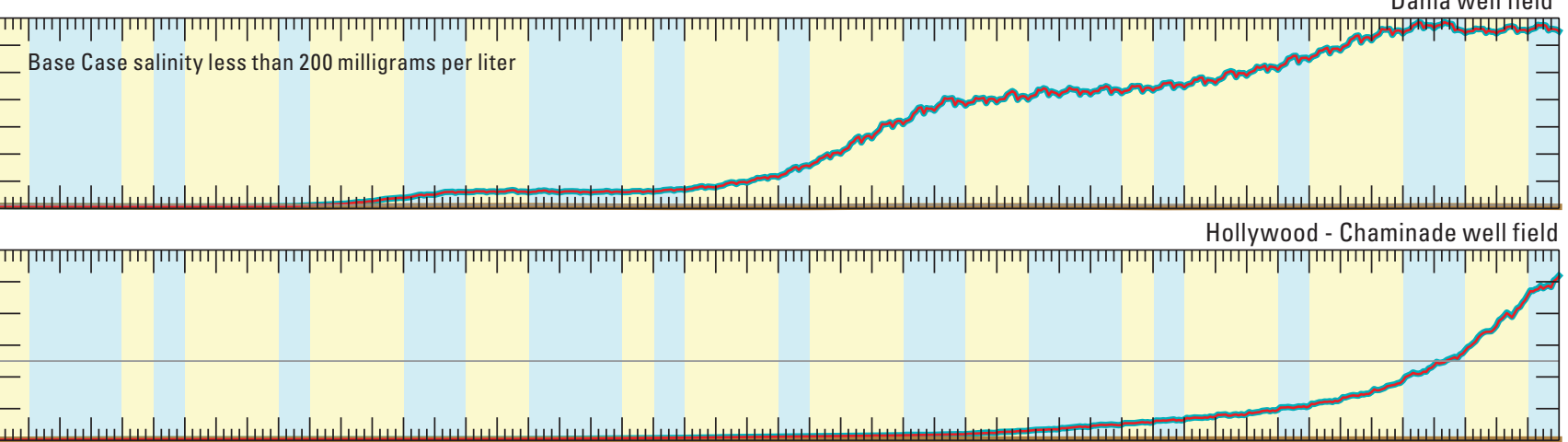
Hollywood - South well field

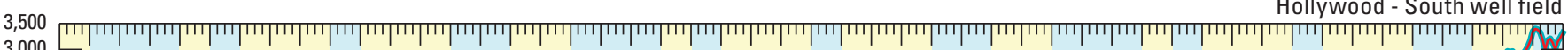

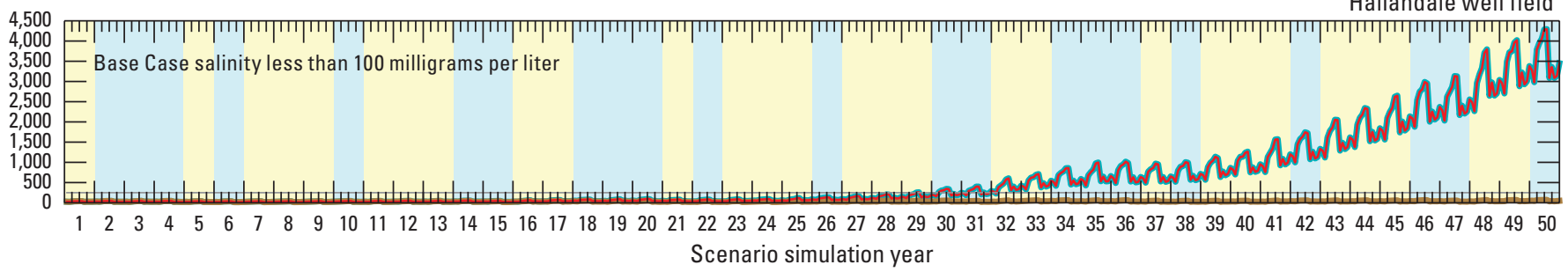

Figure 37. Simulated, flow-weighted, average chloride concentration at select well fields for the Base Case Scenario, and Scenarios 4 and 5. Yellow shading indicates drier than average climatic periods, and blue shading indicates wetter climatic periods, as shown in figure 27. 


\section{Effects of Artificial Recharge in Hallandale Beach on Salinity Distribution}

Scenario 6 tests the effects of proposed/hypothetical recharge wells in Hallandale Beach with a high rate of sea-level rise (fig. 38). For this scenario, 16 recharge wells are constructed east of the Hallandale well-field area to the base of the Biscayne aquifer (15 wells are open to layer 10 and 1 well is open to layers 8-10) (Mike Zygnerski, Broward County Environmental Planning and Community Resilience Division, written commun., 2014). From October to May, 6.9 Mgal/d of water having a total dissolved solids concentration of $1,000 \mathrm{mg} / \mathrm{L}$ is injected into the aquifer; from June to September, no water is injected. The highest rate of sea-level rise is simulated, the same as that used in Scenario 4.
Results show a localized freshening of the aquifer near the injection wells (figs. 38, 39). From 10 years onward, the area of freshening in the aquifer is stable, whereas elevated salinity at the western edge of the plume continues to gradually move westward (fig. 39). The westward advance of the interface in the Hallandale well-field area extends beyond that of Scenario 4 from an increased rate of sea-level rise alone. Pressure from the injected freshwater forces the saltwater to move westward beneath and above, and probably laterally around, the localized injection zone. The simulated, flow-weighted average chloride concentrations at the Hallandale well field indicate a slight increase in salinity during the 50-year simulated period relative to the comparable simulation without the injection wells (Scenario 4) (fig. 40). These results indicate the injection wells as posed may locally freshen the groundwater, but may also cause salinity to increase slightly in the water withdrawn from the well field to the east.

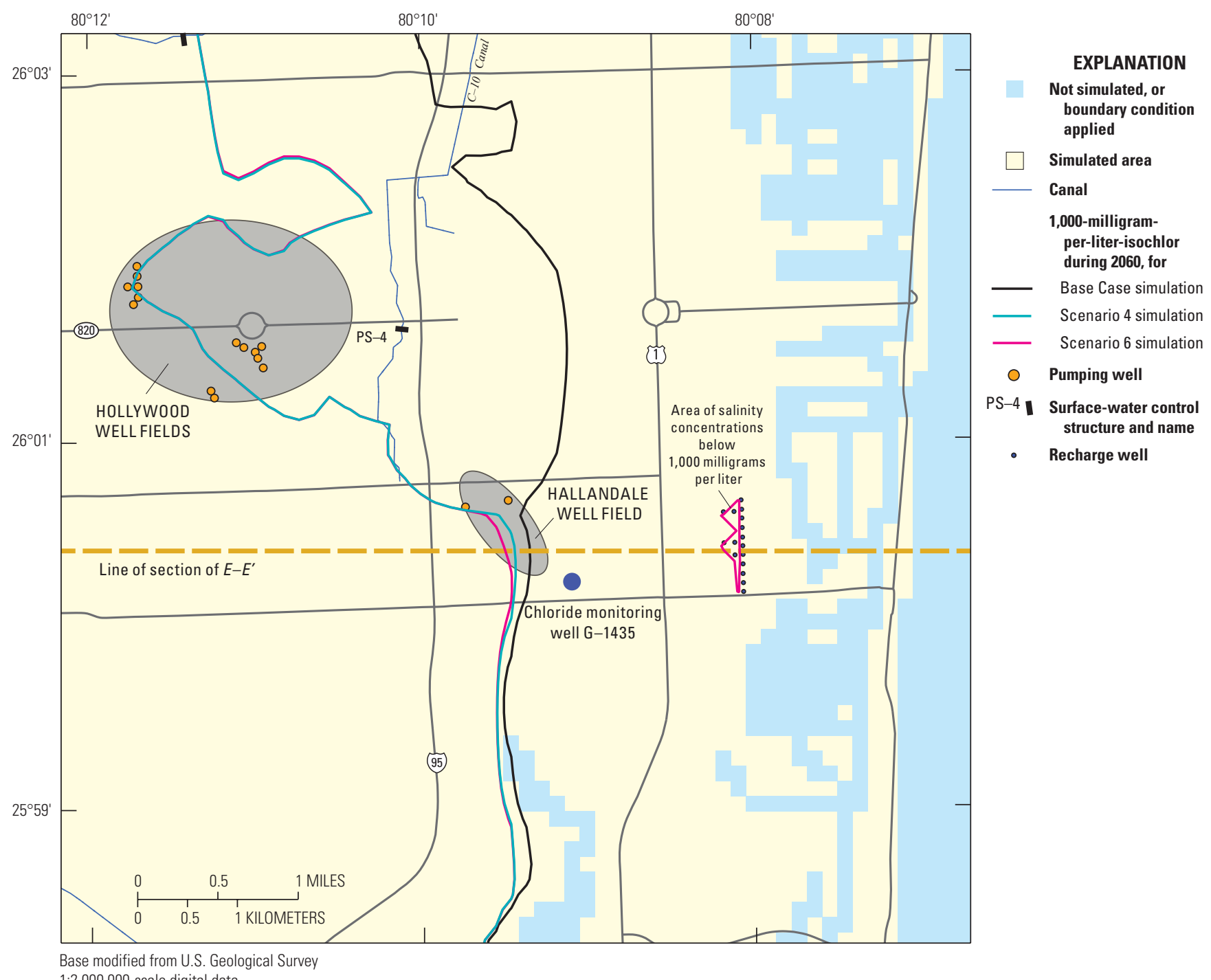

$1: 2,000,000$-scale digital data

Figure 38. Simulated extent of the 1,000-milligram-per-liter isochlors for the Base Case Scenario, and Scenarios 4 and 6 during 2060. 


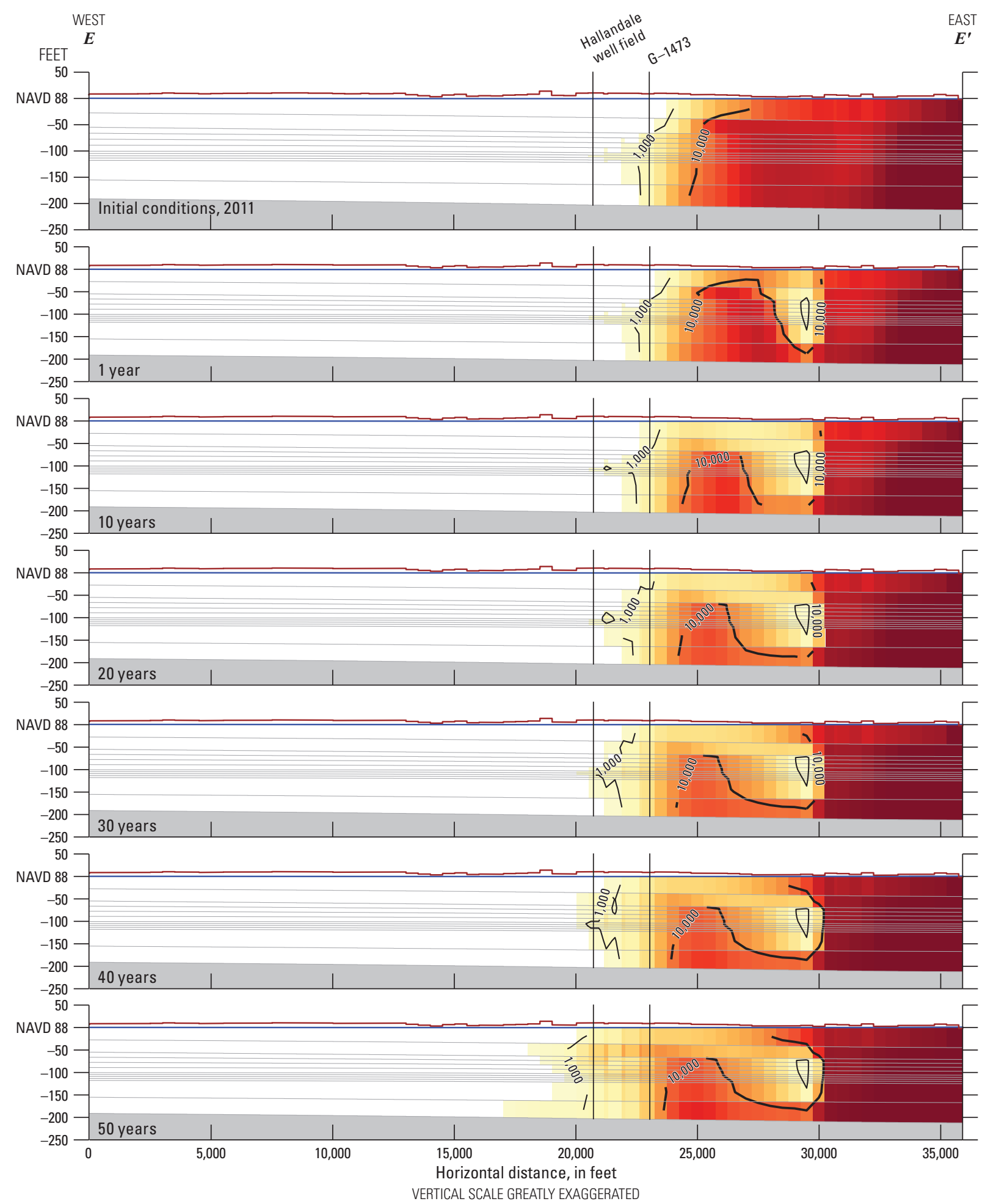

EXPLANATION

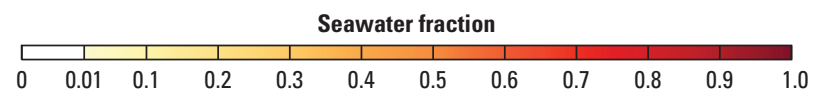

Figure 39. Cross sections of simulated salinity distribution in the Hallandale Beach area after 1, 10, 20, 30, 40, and 50 years simulated time for Scenario 6 (location of cross section shown in fig. 18A). 
16-year simulated meteorological cycle

Hollywood - Chaminade well field

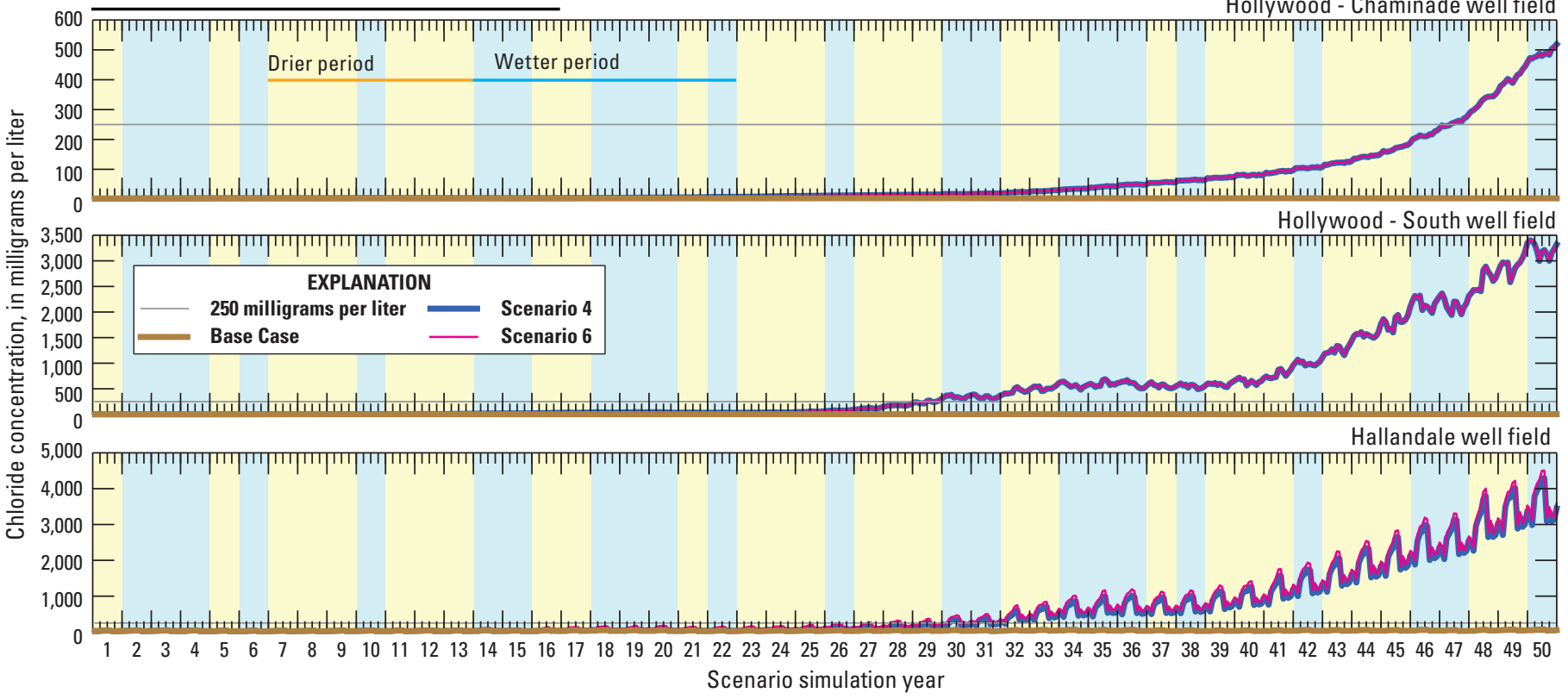

Figure 40. Simulated, flow-weighted, average chloride concentration at select well fields for the Base Case, and Scenarios 4 and 6 . Yellow shading indicates drier than average climatic periods, and blue shading indicates wetter climatic periods, as shown by rainfall deviations from the mean in figure 27.

\section{Model Limitations}

Generally, groundwater flow and transport models are limited by the equations used to represent processes, the algorithms used to make the calculations temporally and in multiple spatial dimensions, the spatial and temporal scale at which the calculations are made, and uncertainty in the physical properties and boundary conditions of the system.

More specifically, model results presented herein should be interpreted in consideration of the limitations of this model and the hypothetical scenarios. Solute-transport models are best at indicating general spatial and temporal trends in salinity, rather than reproducing local and short-term variability, because they are typically difficult to calibrate (Konikow, 2011). Although the model simulated the threedimensional distribution of salinity in the Biscayne aquifer (which is a subset of the surficial aquifer system, fig. 6), and the mapped interface indicates the two-dimensional, westernmost extent of salinity greater than $250-\mathrm{mg} / \mathrm{L}$ chloride in the entire surficial aquifer system in 2009, the general extent of the resulting interfaces are similar (fig. 17). Both indicate a westward bulge in the interface in the central part of the study area, compared with the more seaward location of the interface toward the northern and southern boundaries of the county. Temporal trends in salinity are not represented by the model at G-2899, G-2352, G-2900, and G-2697 (fig. 1-21). Model results in this area may be confounded by more complex interactions between pumping, recharge, and canal leakage than are understood or represented in the model, or by a more complex distribution of physical properties than available data can represent. Uncertainty in initial conditions may also contribute to discrepancies. In the northern part of the model, discrepancies may be caused by a lack of control points with which to calibrate the transport properties of the model.

Uncertainties in initial conditions and stresses early in the simulation limit the reliability of absolute model results for hypothetical future changes in stresses. The salinity distribution prior to 1950 is largely unknown, as is the long-term movement of salinity in response to earlier stresses, such as historical sea-level rise. The initial salinity distribution was developed by simulating a 200 -year period without groundwater pumping, until salinity changes were small (quasi-steady-state conditions), and then adjusted during the calibration process to improve model fit. If the calibrated initial salinity distribution is inaccurate, it may cause errors in calibrated transport properties. If the calibrated transport properties have not been properly adjusted to account for transience in the initial distribution of salinity, then future simulations may overestimate landward migration of the freshwater-saltwater interface. Furthermore, calibration is affected by uncertainty in the stress distribution early in the simulation. For example, the pre-1974 pumping distribution is spatially and temporally more uncertain than that after 1974, which can affect the calibration of transport properties 
constrained particularly by the limited salinity data for the early part of the calibration period. Similarly, the vertical distribution of groundwater withdrawn through wells from subunits in the aquifer is unknown and the simple approach used to distribute groundwater withdrawals among individual layers in the model will affect the resulting calibration of groundwater flow and transport parameters and the simulated vertical distribution of flow.

Results of scenario simulations should be interpreted in a comparative rather than absolute manner because future conditions are unknown. Moreover, the range in predicted rates of sea-level rise is large, and this report does not address which rate is most likely to be accurate. Instead, it describes simulations using reported and conceptually reasonable predictions that range from no sea-level rise to a high rate of sea-level rise. The model results generally indicate how and where the existing salinity distribution may change relative to the actual distribution for the relative increases in sea level. For example, the model predicts increasing landward movement of the elevated salinity along and near the North New River canal with higher rates of sea-level rise; therefore, this area in particular may be more susceptible than surrounding areas to saltwater intrusion with rising sea level. Results should not be used, however, to predict a specific concentration at a specific future date for a specific sea-level rise rate.

Future stress distributions are also unknown. Pumping configurations and magnitudes could change with changes in regulations, population distribution, new well construction or well abandonment, or with changes in climatic conditions or salinity distribution in the surface-water system. Future scenario simulation results are based on the assumption that future pumping distributions remain similar to current distributions. Scenario results do indicate that a reduction in pumping could counteract landward movement of salinity, and that increases could promote landward movement of salinity in areas where salinity distribution is sensitive to pumping stresses, which may be the case in the southern part of the model area. The model should not be used, however, to determine exact amounts of pumping reductions that would result in specific reductions in well-field salinities.

\section{Summary and Conclusions}

Water-supply management of the Biscayne aquifer in Broward County, Florida (fig. 1), has become increasingly challenging because of the susceptibility of the aquifer to saltwater intrusion, and because of increasing water-supply demand and sea-level rise. To aid in the management of the Biscayne aquifer in Broward County, the U.S. Geological Survey (USGS) in cooperation with Broward County Environmental Planning and Community Resilience Division, examined the causes of saltwater intrusion and the effects of future alterations to the hydrologic system on salinity distribution in eastern Broward County. The purpose of this report is to evaluate the effects of pumping and historical sea-level rise on salinity distribution from 1950 to the present, and to predict the effects of hypothetical future alterations to the hydrologic system on salinity distribution in the Biscayne aquifer in the southern and central parts of eastern Broward County. The study area extends from the area just east of the Atlantic coastline to the area just west of the major canals separating the Everglades from the urbanized part of the county, and from the $\mathrm{C}-14$ basin in the north to the $\mathrm{C}-9$ east and west basins in the south.

To meet study objectives, and drawing largely on a study using a variable density solute transport model in the northern part of coastal Broward County, a variable-density, solute-transport groundwater flow model was developed using SEAWAT and associated programs (appendix 1). These types of models are typically difficult to calibrate, so the primary goal was to reproduce major trends and locally generalized distributions of salinity in the Biscayne aquifer. The model was used to (1) evaluate the sensitivity of groundwater pumping and sea-level rise on the current and historical distribution of salinity in groundwater, and (2) evaluate the hypothetical future effects of increases in pumping, variable rates of sea-level rise, movement of a salinity control structure, and use of drainage recharge wells on salinity distribution.

Groundwater flow and solute transport in the carbonate Biscayne aquifer in Broward County are controlled by extremely high permeability and heterogeneity in aquifer properties. The Biscayne aquifer in Broward County is unconfined to semiconfined, and is thicker, deeper, and generally more permeable from west to east; permeability also increases from the northeastern to southeastern part of the county. Inflows to the groundwater system include recharge from precipitation, which is about 62 inches per year on average; leakage through the canals; and regional groundwater flow, which is generally from the northwest to the southeast across Broward County. Outflows include evapotranspiration, which is probably a little less than the average estimated reference evapotranspiration of 57 inches per year; groundwater pumping, which has increased from about 100 million gallons per day in 1960 to about 250 million gallons per day currently (2010); discharge to the canal system; and regional groundwater flow. Saltwater enters the groundwater system laterally from the Atlantic Ocean on the east, and through downward leakage through canals that transport brackish water east of salinity control structures. Maps of the position of the saltwater interface in Broward County since before 1950 to 2009 show an apparent westward migration, but maps are often incomplete and unsuitable for comparison because the data used are from different depth intervals, different monitoring locations, and reflect different reference chloride concentrations. Consistent sampling of specific monitoring sites over long periods of time and periodic induction logging 
indicate locations where salinity is increasing with time and migrating vertically in the aquifer.

Simulation results indicate that the model produces results comparable to the mapped 2009 saltwater interface, although it should be noted that the model results and the mapped interface represent somewhat different things. The mapped interface is the estimated location of the 250-milligram-per-liter isochlor, in the surficial aquifer system, at its furthest inland extent, whereas the model simulates the transient, three-dimensional, variable distribution of salinity in the Biscayne aquifer, based on mathematical representation of flow and transport processes. Generally, the model represents a greater westward extent of elevated salinity in the central part of the intruded area and a lesser extent in the northern and southernmost parts of the intruded area. Simulation results also show limited historical change in the extent of elevated salinity in the northern part of the intruded area, and progressive westward movement of elevated salinity near the North New River canal, and southeast of the Hallandale well-field area. Change in the extent of elevated salinity southeast of the Hallandale well-field area essentially ceased between 1990 and 2000, when pumping at Hallandale well field was reduced by nearly half.

Sensitivity simulations indicate that the extent of elevated salinity south of the Dania Cut-Off canal is more sensitive to pumping than to sea-level rise, whereas the extent of elevated salinity south of the North New River canal and along the Dania Cut-Off canal is relatively more sensitive to sea-level rise than to pumping. The extent of elevated salinity in the area of the confluence of the North New River and South New River canals is about equally sensitive to pumping and sealevel rise. Groundwater salinity south of the Dania well-field area is derived largely from the Atlantic Ocean, whereas in the area between the Dania Cut-Off canal and the North New River canal, salinity is derived more from downward leakage through canals. In areas where the source of saltwater is largely offshore, from the Atlantic Ocean, the interface is more sensitive to effects of pumping. In areas where the source of salinity is downward leakage of brackish water through canals, the interface is more sensitive to the effects of sea-level rise. Once saltwater enters the aquifer by either means, however, local pumping stresses can affect the movement of salinity.

The model was used to test the effects on future salinity distribution of hypothetical future changes in pumping distribution, sea-level rise, movement of a coastal salinitycontrol structure, and installation of recharge wells. The Base Case Scenario showed that, without sea-level rise and with permitted pumping, the simulated interface (1) generally advanced inland in the southern part of the intruded area from the 2011 position, where nearby permitted pumping is greater than previously existing pumping; (2) retreated in the central part of the intruded area from the 2011 position, where nearby permitted pumping is less than previously existing pumping; and (3) remained close to the 2011 position in the northern part of the study area. Climatic effects, such as periods of drought or high precipitation, may augment or counteract long-term effects of changes in pumping on aquifer salinity at well fields. If pumping remains near previously existing rates, results of Scenario 1 show that the interface retreats relative to the Base Case Scenario from about the Dania well-field area to the southern end of the simulated area.

Scenarios 2, 3, and 4 simulated increasing rates of sealevel rise, based on National Research Council low, medium, and high sea-level rise curves, with permitted pumping distribution. In general, with increased rates of sea-level rise, the simulated freshwater-saltwater interface advances progressively inland, and flow-averaged salinities at Dania, Hallandale, and Hollywood well fields increase commensurately. A slight increase in salinity is predicted at the highest sea-level rise rates for the Dixie well field.

Scenario 5 results show that, for the highest sea-level rise rates and permitted pumping, if the $\mathrm{G}-54$ salinity-control structure on the North New River canal is moved southeastward approximately 2.4 miles, the saltwater interface may be prevented from moving westward along and near the North New River canal, but beneficial effects are limited to those areas of the aquifer where elevated salinity is caused by downward leakage of brackish water from the North New River canal.

Scenario 6 results show that, for the highest sea-level rise rates and permitted pumping distribution, simulated freshwater recharge wells in Hallandale Beach had a localized freshening effect in the aquifer. Saline water continued to be transported around and beneath the injection sites, and the simulated interface moved slightly more landward and into the well-field area in response to the increased pressure of injection.

Model results should be considered in relative rather than absolute terms, because of uncertainty in the physical properties and boundary conditions of the system, uncertainty in historical and future conditions, and generalizations made in the mathematical relationships used to describe the physical processes of groundwater flow and transport. Solute transport models are typically difficult to calibrate, and compromises usually must be made to better fit one type of data in one area or during one time period, resulting in a poorer fit for another type of data in another area or for another time period. Simulating the groundwater system of the Biscayne aquifer in Broward County is confounded by complex interactions between pumping, recharge, and canal leakage; by a more complex distribution of physical properties than available data can represent; and by uncertainty in historical conditions in areas without observation wells. Furthermore, future conditions are hypothetical at best. Although results should not be used to predict the absolute response of the distribution of salinity to pumping distributions, sea-level rise, or mitigation activities, these results provide categorical information on the relative scale of response of the system to these types of changes. 


\section{References Cited}

Andersen, P.F., Mercer, J.W., and White, H.O., Jr., 1988, Numerical modeling of salt-water intrusion at Hallandale, Florida: Ground Water, v. 26, no. 5, p. 619-630.

Broward County Planning and Redevelopment Division, 2009, Broward's Population through the Year 2035: Accessed September 14, 2015, at http://www.broward.org/Planning AndRedevelopment/DemographicsAndEconomics/Documents/ bbtn57.pdf.

Camp Dresser and McKee and DHI Water and Environment, 2002, Modeling water management practices in Central Broward County, Florida, Phase 2, Numerical model building and modeling results: Consultant's report prepared for Broward County.

Cunningham, K.J., Wacker, M.A., Robinson, Edward, Dixon, J.F., and Wingard, G.L., 2006, A cyclostratigraphic and borehole-geophysical approach to development of a three-dimensional conceptual hydrogeologic model of the karstic Biscayne aquifer, southeastern Florida: U.S. Geological Survey Scientific Investigations Report 2005-5235, 69 p., plus CD-ROM.

Dausman, Alyssa, and Langevin, C.D., 2005, Movement of the saltwater interface in the surficial aquifer system in response to hydrologic stresses and water-management practice, Broward County, Florida: U.S. Geological Survey Scientific Investigations Report 2004-5256, 73 p.

DHI Water and Environment and Camp Dresser and McKee, 2005, Task 4.2 South Area Drainage Assessment MIKE SHE model report-Broward County, Florida: Consultant's report prepared for Broward County, $173 \mathrm{p}$.

Doherty, J.E., 2010, PEST, model-independent parameter estimation-User manual (5th ed.): Brisbane, Australia, Watermark Numerical Computing.

Doherty, J.E., and Hunt, R.J., 2010, Approaches to highly parameterized inversion-A guide to using PEST for groundwater model calibration: U.S. Geological Survey Scientific Investigation Report 2010-5169, 59 p.

Dunn, D., 2001, Three-dimensional analysis of saltwater intrusion: City of Pompano Beach area, Broward County, Florida: Technical Report Series TR-01-06.

Fairbanks, R.G., 1989, A 17,000-year glacio-eustatic sea level record-Influence of glacial melting rates on the Younger Dryas event and deep-ocean circulation: Nature, v. 342, no. 7, p. 637-642.

Fish, J.E., 1988, Hydrogeology, aquifer characteristics, and ground-water flow of the surficial aquifer system Broward County, Florida: U.S. Geological Survey Water-Resources Investigations Report 87-4034, 80 p., plus appendix.
Giddings, J.B., Kuebler, L.L., Restrepo, J.I., Rodberg, K.A., Montoya, A.M., and Radin, H.A., 2006, Lower east coast subregional (LECsR) MODFLOW model documentation: South Florida Water Management District draft report, 213 p., plus app., accessed May 27, 2014, at http://www. sfwmd.gov/portal/page/portal/xweb $\% 20$ - $\% 20$ release $\% 20$ $3 \% 20$ water $\% 20$ supply/ground $\% 20$ water $\% 20$ modeling.

Guha, H., and Panday, S., 2012, Impact of sea level rise on groundwater salinity in a coastal community of south Florida: Journal of the American Water Resources Association, v. 48 , no. 3, p. 510-529.

Hughes, J.D., and White, J.T., 2014, Hydrologic conditions in urban Miami-Dade County, Florida, and the effect of groundwater pumpage and increased sea level on canal leakage and regional groundwater flow: U.S. Geological Survey Scientific Investigations Report 2014-5162, 175 p.

Islam, N., and Dunn, D., 2006, Recalibration and consolidation of integrated surface water and groundwater models for Broward County: Broward County Environmental Protection Department, Water Resources Division, 40 p.

Jacobs J.M., Mecikalski, J.R., and Paech, S.J., 2008, Satellitebased solar radiation, net radiation, and potential and reference evapotranspiration estimates over Florida: Report prepared for the U.S. Geological Survey, 138 p., accessed March 12, 2013, at http://fl.water.usgs.gov/et/publications/ GOES_FinalReport.pdf.

Kemp, A.C., Horton, B.P., Donnelly, J.P., Mann, M.E., Vermeer, M., and Rahmstorf, S., 2011, Climate related sea-level variations over the past two millennia: Proceedings of the National Academy of Sciences, v. 108, no. 27, p. 11017-11022.

Konikow, L.F., 2011, The secret to successful solute-transport modeling: Ground Water, v. 49, no. 2, p. 144-159.

Lacombe, P.J., and Carleton, G.B., 2002, Hydrogeologic framework, availability of water supplies, and saltwater intrusion, Cape May County, New Jersey: U.S. Geological Survey Water-Resources Investigations Report 01-4246, $152 \mathrm{p}$.

Langevin, C.D., Thorne, D.T., Jr., Dausman, S.M., Sukop, M.C., and Guo, Weixing, 2007, SEAWAT Version 4-A computer program for simulation of multi-species solute and heat transport: U.S. Geological Survey Techniques and Methods, book 6, chap. A22, 39 p.

Langevin, C.D., and Zygnerski, M., 2013, Effect of sea-level rise on salt water intrusion near a coastal well field in southeastern Florida: Ground Water, v. 51, no. 5, p. 781-803.

Marella, R.L., 1999, Water withdrawals, use, discharge and trends in Florida, 1995: U.S. Geological Survey WaterResources Investigations Report 99-4002, 90 p. 
Marella, R.L., 2004, Water withdrawals, use, discharge, and trends in Florida, 2000: U.S. Geological Survey Scientific Investigations Report 2004-5151, 136 p.

Marella, R.L., 2009, Water withdrawals, use, and trends in Florida, 2005: U.S. Geological Survey Scientific Investigations Report 2009-5125, 49 p.

Marella, R.L., 2014, Water withdrawals, use, and trends in Florida, 2010: U.S. Geological Survey Scientific Investigations Report 2014-5088, 59 p.

Merritt, M.L., 1996, Assessment of saltwater intrusion in southern coastal Broward County, Florida: U.S. Geological Survey Water-Resources Investigations Report 96-4221, $133 \mathrm{p}$.

Monti, J., Jr., Misut, P.E., Busciolano, R., 2009, Simulation of variable-density ground-water flow and saltwater intrusion beneath Manhasset Neck, Nassau County, New York, 1905-2005: U.S. Geological Survey Scientific Investigations Report 2008-5166, 69 p.

Payne, D.F., 2010, Effects of sea-level rise and pumpage elimination on saltwater intrusion in the Hilton Head Island area, South Carolina, 2004-2104: U.S. Geological Survey Scientific Investigations Report 2009-5251, 83 p.

Perkins, R.D., 1977, Depositional framework of Pleistocene rocks in south Florida, in Enos, Paul,and Perkins, R.D., eds., Quaternary sedimentation in south Florida: Geological Society of America Memoir 147, p. 131-198.

Prinos, S.T., 2013, Saltwater intrusion in the surficial aquifer system of the Big Cypress Basin, southwest Florida, and a proposed plan for improved salinity monitoring: U.S. Geological Survey Open-File Report 2013-1088, 58 p.

Prinos, S.T., Wacker, M.A., Cunningham, K.J., and Fitterman, D.V., 2014, Origins and delineation of saltwater intrusion in the Biscayne aquifer and changes in the distribution of saltwater in Miami-Dade County, Florida: U.S. Geological Survey Scientific Investigations Report 2014-5025, 101 p., plus app.

Reese, R.S., and Cunningham, K.J., 2000, Hydrogeology of the gray limestone aquifer in southern Florida: U.S. Geological Survey Water-Resources Investigations Report 99-4213, 244 p.

Renken, R.A., Dixon, J., Koehmstedt, J., Ishman, S., Lietz, A.C., Marella, R.L., Telis, P., Rogers, J., and Memberg, S., 2005, Impact of anthropogenic development on coastal groundwater hydrology in southeastern Florida, 1900-2000: U.S. Geological Survey Circular 1275, 77 p.

Restrepo, J.I., Bevier, C., and Butler, D., 1992, A threedimensional finite difference ground water flow model of the surficial aquifer system, Broward County, Florida: South Florida Water Management District Technical Publication 92-05, 262 p.
Skinner, Courtney, Bloetscher, Fredrick, and Pathak, C.S., 2009, Comparison of NEXRAD and rain gauge precipitation measurements in South Florida: Journal of Hydrologic Engineering, v. 14, no. 3, p. 248-260. [Also available at http://dx.doi.org/10.1061/(ASCE)10840699(2009)14:3(248).]

Southeast Florida Regional Climate Change Compact Technical Ad hoc Work Group, 2011, A unified sea level rise projection for southeast Florida: Accessed April 8, 2015, at http://www.broward.org/NaturalResources/ClimateChange/ Documents/SE\%20FL\%20Sea\%20Level\%20Rise\%20White\%20 Paper\%20Apri1\%202011\%20ADA\%20FINAL.pdf.

South Florida Water Management District, n.d., Rainfall historical sites and basins: Accessed July 21, 2014, at http://www.sfwmd.gov/portal/page/portal/xweb\%20 weather/rainfall $\% 20$ historical $\% 20 \% 28$ normal $\% 20$ florida\%20annual\%20rainfall\%20map $\% 29$.

South Florida Water Management District, 2009, Water utilities water demand reduction during the 2007-2009 water shortage restrictions: South Florida Water Management District report, 21 p., plus apps., accessed May 30, 2014, at http:/www.sfwmd.gov/portal/page/portal/ xrepository/sfwmd_repository_pdf/water_demand_reduction report_final.pdf.

South Florida Water Management District, 2011, Broward County estimated position of the saltwater interface, surficial aquifer system, April/May 2009: 1 map, accessed May 23, 2014, at http://www.sfwmd.gov/portal/page/portal/ xrepository/sfwmd_repository_pdf/broward_isochlor_ apr-may_2009opt.pdf.

South Florida Water Management District, 2012, DBHYDRO database: Accessed October 2012, at http://www.sfwmd. gov/portal/page/portal/xweb\%20environmental $\% 20$ monitoring/dbhydro\%20application.

U.S. Army Corps of Engineers, 2009, Water resource policies and authorities incorporating sea-level change considerations in civil works programs: Circular 1165-2-211, 3 p., plus app.

U.S. Census Bureau, 1995, Population of Counties by Decennial Census: 1900 to 1990: U.S. Census Bureau Web site accessed December 23, 2013, at http://www.census.gov/ population/cencounts/fl190090.txt.

U.S. Census Bureau, 2013, Annual Estimates of the Resident Population: April 1, 2010 to July 1, 2012: U.S. Census Bureau Web site accessed December 23, 2013, at http://factfinder.census.gov/faces/tableservices/jsf/pages/ productview.xhtml? src $=$ bkmk.

U.S. Census Bureau, n.d., Census 2000 Summary File 1, (SF 1) 100-Percent Data: U.S. Census Bureau Web site accessed December 23, 2013, at http://factfinder.census.gov/ faces/tableservices/jsf/pages/productview.xhtml? src=bkmk. 
U.S. Environmental Protection Agency, 2013, Sole source aquifers in the southeast: Web site accessed March 1, 2016, at http://archive.epa.gov/pesticides/region4/water/groundwater/web/html/r4ssa.html.

U.S. Geological Survey, 2012a, Water-resources data for the United States, Water Year 2011: U.S. Geological Survey Water-Data Report WDR-US-2011, site 255843080090901, accessed February 7, 2014, at http://wdr.water.usgs.gov/ wy2011/pdfs/255843080090901.2011.pdf.

U.S. Geological Survey, 2012b, Water-resources data for the United States, Water Year 2011: U.S. Geological Survey Water-Data Report WDR-US-2011, site 260325080113901, accessed February 7, 2014, at http://wdr.water.usgs.gov/ wy2011/pdfs/260325080113901.2011.pdf.

U.S. Geological Survey, 2012c, Water-resources data for the United States, Water Year 2011: U.S. Geological Survey Water-Data Report WDR-US-2011, site 261304080072501, accessed February 7, 2014, at http://wdr.water.usgs.gov/ wy2011/pdfs/261304080072501.2011.pdf.
U.S. Geological Survey, 2013, Water-resources data for the United States, Water Year 2012: U.S. Geological Survey Water-Data Report WDR-US-2012, site 260326080120301, accessed February 7, 2014, at http://wdr.water.usgs.gov/ wy2012/pdfs/260326080120301.2012.pdf.

U.S. Geological Survey, 2014, Water Quality Samples for Florida: Sample Data: accessed March 10, 2014, at http://nwis.waterdata.usgs.gov/fl/nwis/qwdata.

Zetler, B.S., 1982, Computer applications to tides in the National Ocean Survey-National Oceanic and Atmospheric Administration, National Ocean Survey, Supplement to manual of harmonic analysis and prediction of tides: Special Publication no. 98, 85 p. 


\section{Appendix 1. Model Construction and Calibration}

A variable-density groundwater flow and solute transport model was developed for the central and southern part of Broward County to simulate saltwater intrusion near the Dixie, Prospect, Dania, Hollywood, and Hallandale well fields and to determine the factors that have contributed to historic saltwater intrusion (Hughes and others, 2016). The model was then used to evaluate the potential future effects of increased groundwater pumping, sea-level rise, alternative surface-water management, and small-scale aquifer storage on the position of the freshwater-saltwater interface. To ensure that the inversion process maximized the information content of the observation dataset, the model simulation period was 62 years and the last 42-year period (1970-2012) was used for calibration using a highly parameterized approach. This approach provided assurance that the saltwater intrusion model would be calibrated as well as possible, subject to limitations associated with numerical accuracy, the calibration dataset, the ability to accurately characterize past unknown hydrologic conditions, and the ability to accurately represent input parameters not adjusted as part of the calibration process. Thus, it is unlikely that alternative calibration approaches with similar constraints would result in a better-calibrated model.

\section{Simulation Code}

SEAWAT is a coupled version of MODFLOW and MT3DMS designed to simulate variable-density groundwater flow and solute transport (Guo and Langevin, 2002; Langevin and others, 2003; Langevin and Guo, 2006). The simulations reported here were performed using SEAWAT Version 4 (Langevin and others, 2007), which is based on MODFLOW-2000 (Harbaugh and others, 2000) and MT3DMS Version 5 (Zheng and Wang, 1999; Zheng, 2006).

SEAWAT uses a linear equation of state to calculate fluid density as a function of solute concentration. For the present application, the solute concentration, $C$, simulated by the model is the fractional concentration of seawater salts. Fractional seawater concentrations were calculated by normalizing observed chloride concentrations by a seawater chloride concentration of 19,000 milligrams per liter (mg/L). Freshwater was assumed to have a fractional seawater concentration of zero, and seawater was assumed to have a fractional seawater concentration of 1 . Fluid density, $\rho$, is calculated by SEAWAT using a linear relation subject to the constraints that freshwater has a fluid density of 28.3127 kilograms per cubic foot $\left(\mathrm{kg} / \mathrm{ft}^{3}\right)$ and seawater has a density value of $29.0205 \mathrm{~kg} / \mathrm{ft}^{3}$. The resulting equation of state used for all of the simulations reported here is $\rho=28.3127+0.7088 C$, where $C$ is chloride concentration.
Prior to model calibration, the implicit finite-difference solution method and the explicit third-order Total Variation Diminishing (TVD) scheme for solving the transport equation were evaluated to determine the most appropriate approach for this study. TVD is mass conservative and can minimize numerical dispersion, but because it is an explicit scheme, it is subject to time-step constraints and can be computationally demanding. Testing indicated that the implicit finite-difference solution method was sufficient for this study. Dispersivity values in all layers were specified to be zero, because the implicit finite-difference solution method results in numerical dispersion on the order of one-half of grid cell dimensions, and while physical and chemical dispersion processes occur in reality, appropriate values for modeling are scale dependent and generally unknown. A diffusion coefficient of $1 \times 10^{-9}$ feet squared per day $\left(\mathrm{ft}^{2} / \mathrm{d}\right)$ was specified.

\section{Extent and Discretization}

The active flow model area is approximately 450 square miles $\left(\mathrm{mi}^{2}\right)$ in the eastern part of Broward County and the northeasternmost part of Miami-Dade County and contains the entire $\mathrm{C}-14$, Pompano Canal, $\mathrm{C}-13$ west, $\mathrm{C}-13$ east, $\mathrm{L}-35$ borrow canal, C-12, North New River, C-11 west, C-11 east, C-10, C-9 west, and C-9 east surface-water basins (fig. 1). The active flow model area is generally bounded on the west by the Everglades and Water Conservation Areas 2A, 2B, 3A, and $3 \mathrm{~B}$; on the east by the Atlantic Ocean; on the north by the Hillsboro canal basin; and on the south by Water Conservation Area $3 \mathrm{~B}$ and the $\mathrm{C}-8$ canal basin. The area of actively simulated flow extends a few additional grid cells beyond some of the major canals in the west that delineate the water conservation areas. A 190- $\mathrm{mi}^{2}$ subset of the actively simulated flow-model area also actively simulates transport and extends from the Atlantic Ocean to about 4.5 miles (mi) inland of the approximate extent of the 1996 saltwater interface in Broward County (fig. 1-1). The surficial aquifer in the study area was discretized into 12 layers, 411 rows, and 501 columns using $500 \times 500$-foot (ft) $\left(250,000\right.$-square foot $\left.\left[\mathrm{ft}^{2}\right]\right)$ model cells in the horizontal plane; each model layer contains 50,179 active cells. The grid resolution is fine enough to discretize surfacewater features (for example the $\mathrm{C}-12$ canal) into multiple river cells along their lengths (fig. 1-2).

Model layering was designed to follow a composite of lithostratigraphic and hydrogeologic models for the surficial aquifer system (figs. 5 and 6). Model layers 1 and 2 represent undifferentiated Holocene sediments, the Miami Limestone, and the top of the Fort Thompson Formation, and the Anastasia Formation where it occurs, or the Q5, Q4, and Q3 units (Perkins, 1977). Model layers 3 to 6 correspond to the Q2 unit, 


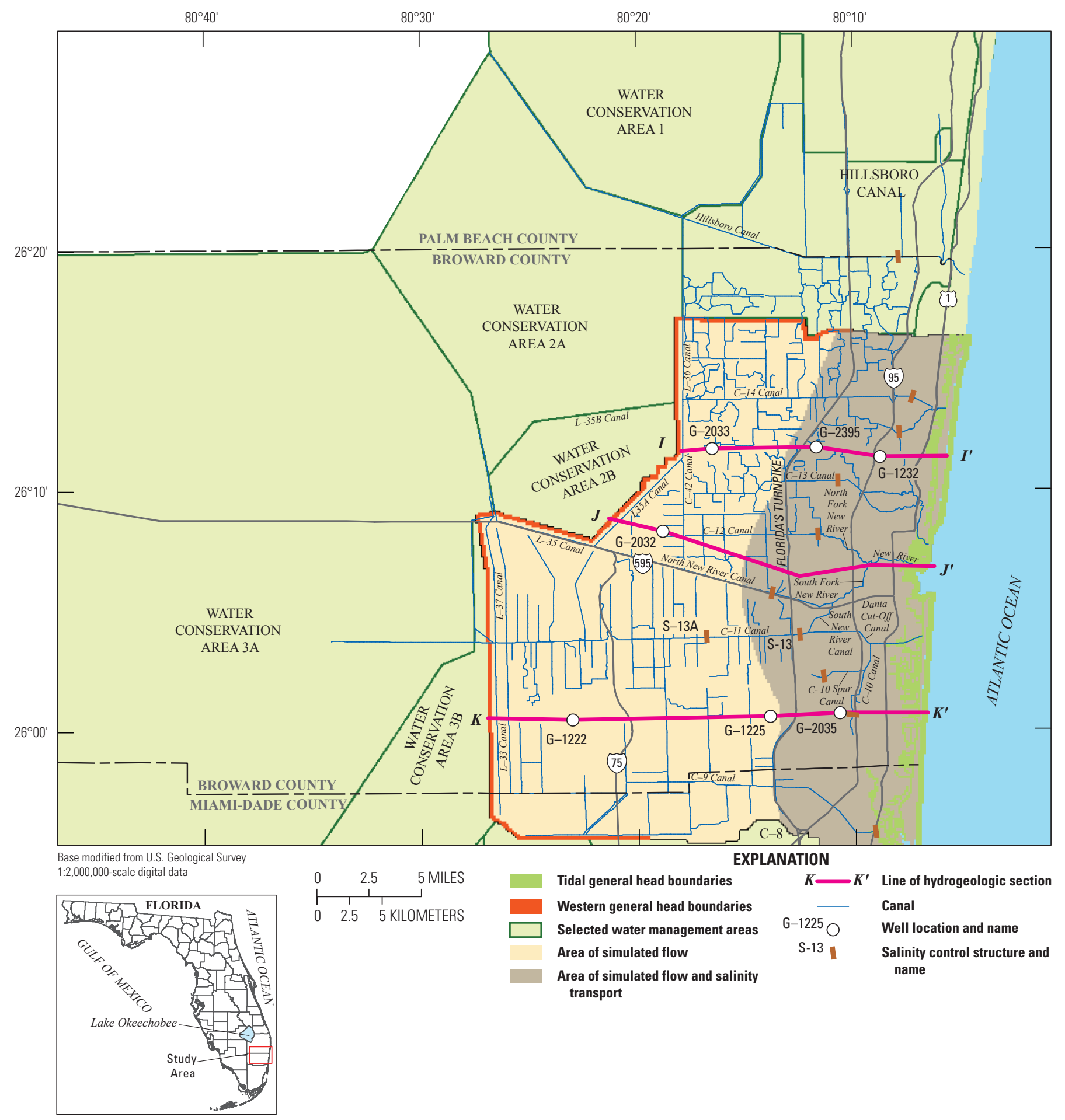

Figure 1-1. Surface-water basins, canals, and surface-water control structures, and groundwater boundary conditions for layer 1 in the flow model area. The active area of the transport model is also shown. 


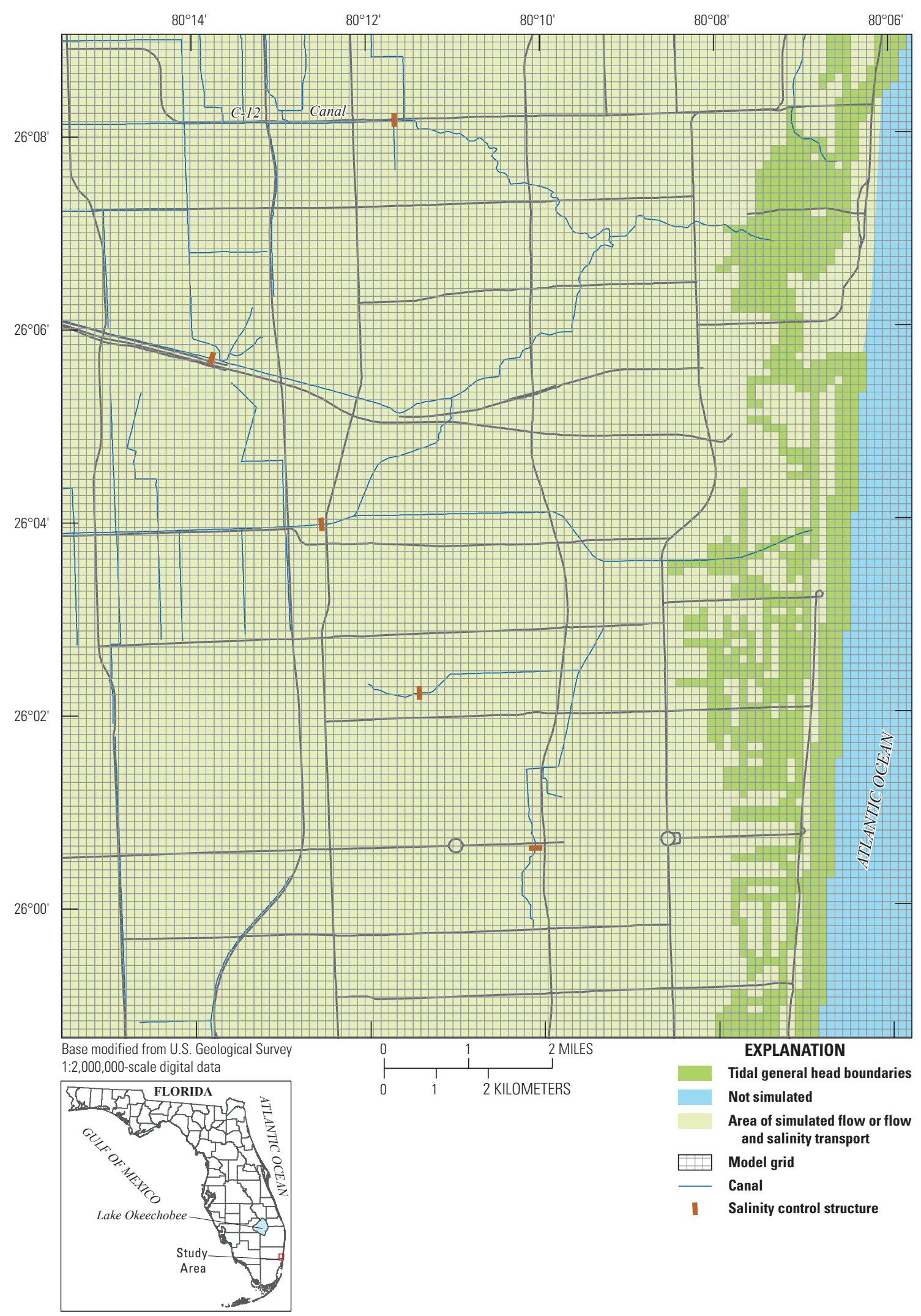

Figure 1-2. Model grid resolution shown in a part of the active groundwater model domain. 
and model layers 7 to 10 correspond to the Q1 unit (Perkins, 1977), or most of the Fort Thompson Formation and the Anastasia Formation, where it occurs, and these compose most of the Biscayne aquifer. Model layers 11 and 12 correspond to the Pinecrest Sand and Ochopee Limestone Members of the Tamiami Formation (hereafter referred to as the "Pinecrest Sand" and "Ochopee Limestone," respectively). In the western part of Broward County, these correspond to the gray limestone aquifer (Reese and Cunningham, 2000) and the upper semiconfining unit that separates it from the Biscayne aquifer; the presence of both units in the eastern part of the county is probably limited.

The distribution of layer thicknesses was calculated by applying anisotropic variogram modeling to control points for depths of corresponding lithostratigraphic units (Giddings and others, 2006). Thickness data from 117 wells and ordinary kriging (Deutsch and Journel, 1998) were used to estimate layer thicknesses at the center of each $500-\mathrm{ft} \times 500$ - $\mathrm{ft}$ cell in a mesh encompassing the model domain. Kriging requires specifying the correlation structure for interpolation, which is described using a function called a semivariogram that relates variance to the distance and spatial orientation between data points. An experimental semivariogram was calculated from the 117 wells by calculating the average variance of the thickness data between pairs of wells having similar separation distances. A mathematical function that models the behavior of the experimental semivariogram, namely a theoretical semivariogram, is usually necessary because the experimental semivariogram contains a finite number of data pairs that cannot fully describe the correlation relation at all separation distances and directions evaluated during the interpolation process (Isaaks and Srivastava, 1989). The SGeMS software suite (Remy and others, 2009) was used to develop the experimental semivariogram and corresponding theoretical semivariogram for each marine sequence within the Biscayne aquifer. The parameters that define the theoretical semivariograms were manually adjusted to improve their agreement with experimental semivariograms and are summarized in table 1-1. Experimental semivariograms for Holocene sediments, the Q-units, the Pinecrest Sand, and the Ochopee Limestone showed anisotropic correlation structure with principal direction oriented N. $10^{\circ}$ E., which approximately coincides with the orientation of the south Florida shoreline.

The calculated layer thicknesses were used in combination with land-surface elevation data developed from 3-ft-resolution, 2007 light detection and ranging (lidar) data (Florida Division of Emergency Management, 2007) and interpolated to the model grid (fig. 1-3) to determine the top and bottom elevations of each of the layers. Interpolated land-surface elevations in the active part of the model ranged from 20 to $-2 \mathrm{ft}$. The top elevation of the Q3-unit, which corresponds to the base elevation of the Miami Limestone (top of layer 2) in the active part of the model ranged from -10 to $-47 \mathrm{ft}$ (fig. 1-4). In general, the thickness of the undifferentiated Holocene sediments, the Q-units, the Pinecrest Sand, and the Ochopee Limestone increases from west to east, and the top and bottom of the units dip to the east within the active part of the model.

The top of the Q2-unit (top of layer 3), in the active model domain dips to the east and ranged in elevation from -22 to $-72 \mathrm{ft}$ (fig. 1-5A). The Q2-unit corresponds to the upper unit of the primary Biscayne aquifer production zone in the active part of the model. The top elevation of the Q1-unit (top of layer 7) in the active part of the model ranged from -40 to $-113 \mathrm{ft}$ (fig. $1-5 B$ ). The top elevation of the Pinecrest Sand Member of the Tamiami Formation (layer 11), which corresponds to the base elevation of the Q1-unit and the Biscayne aquifer (layer 10) in the active part of the model, ranged from -49 to $-138 \mathrm{ft}$ (fig. $1-5 C$ ).

Table 1-1. Theoretical semivariogram models and parameters for Holocene and Pleistocene sediment sequences and Biscayne aquifer hydraulic conductivity.

\begin{tabular}{|c|c|c|c|c|c|c|}
\hline Data item & $\begin{array}{l}\text { Variogram } \\
\text { model }\end{array}$ & $\begin{array}{c}\text { Nugget } \\
\text { contribution } \\
\text { to sill }\end{array}$ & $\begin{array}{l}\text { Variogram } \\
\text { contribution } \\
\text { to sill }\end{array}$ & $\begin{array}{l}\text { Range, } \\
\text { in miles }\end{array}$ & Anisotropy & $\begin{array}{l}\text { Principal direction } \\
\text { of anisotropy, } \\
\text { in degrees }{ }^{1}\end{array}$ \\
\hline Holocene & Exponential & 5 & 10 & 43 & 1.78 & 10 \\
\hline Q5 & Exponential & 5 & 40 & 84 & 6.3 & 10 \\
\hline Q4 & Exponential & 10 & 75 & 78 & 4.65 & 10 \\
\hline Q3 & Spherical & 50 & 300 & 105 & 5.16 & 10 \\
\hline Q2 & Exponential & 20 & 350 & 160 & 3 & 10 \\
\hline Q1 & Exponential & 30 & 250 & 109 & 2.34 & 10 \\
\hline Pinecrest sand (T1) & Exponential & 200 & 400 & 31 & 3.29 & 10 \\
\hline Ochopee Limestone (T2) & Exponential & 100 & 750 & 33 & 1.79 & 10 \\
\hline Hydraulic conductivity $^{2}$ & Exponential & 0 & 3.3 & 9.32 & 1 & 0 \\
\hline
\end{tabular}

\footnotetext{
${ }^{1}$ Degrees clockwise from north.

${ }^{2}$ Log-transformed.
} 
Appendix 1. Model Construction and Calibration

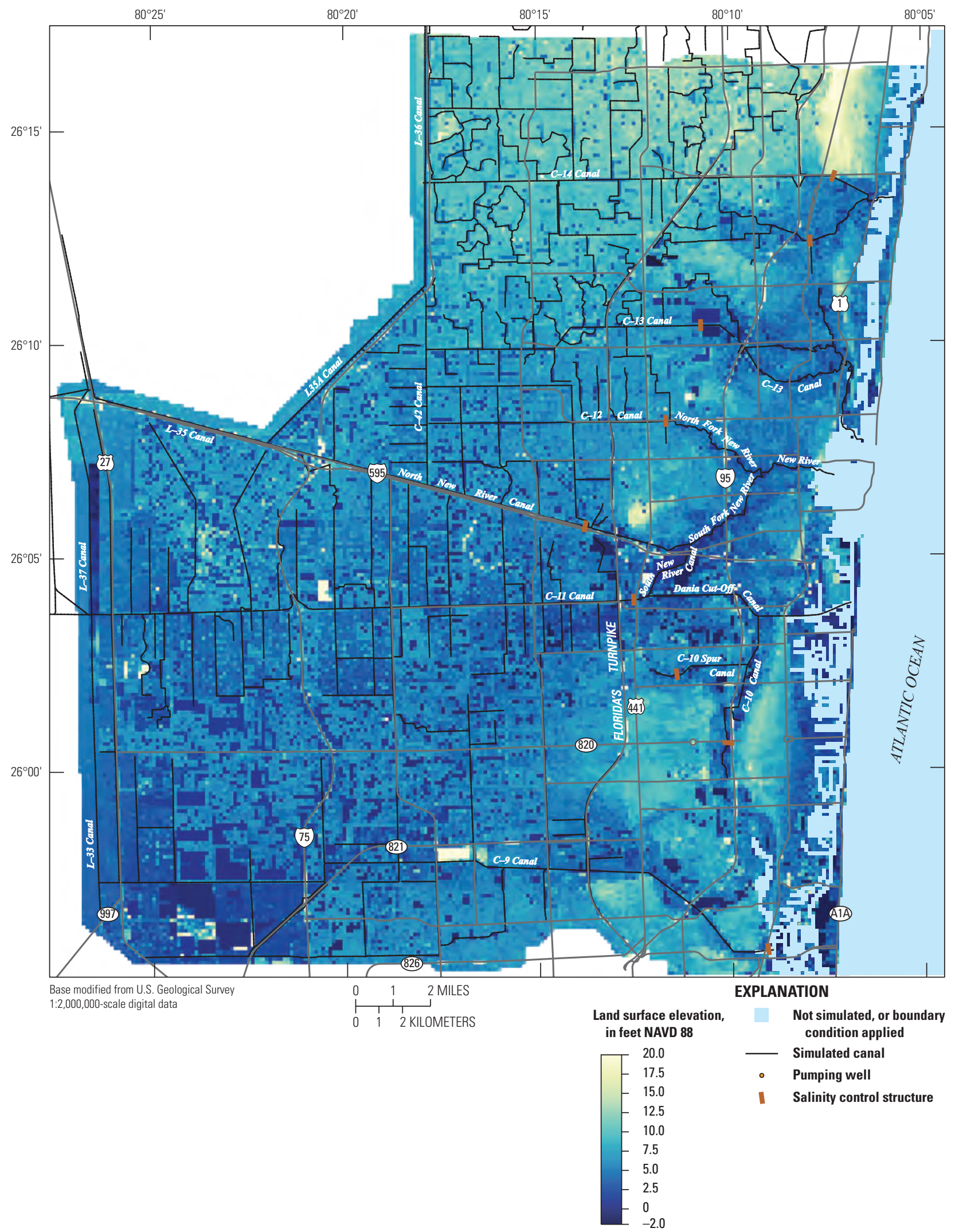

Figure 1-3. Gridded land-surface elevations in the active part of the model. 


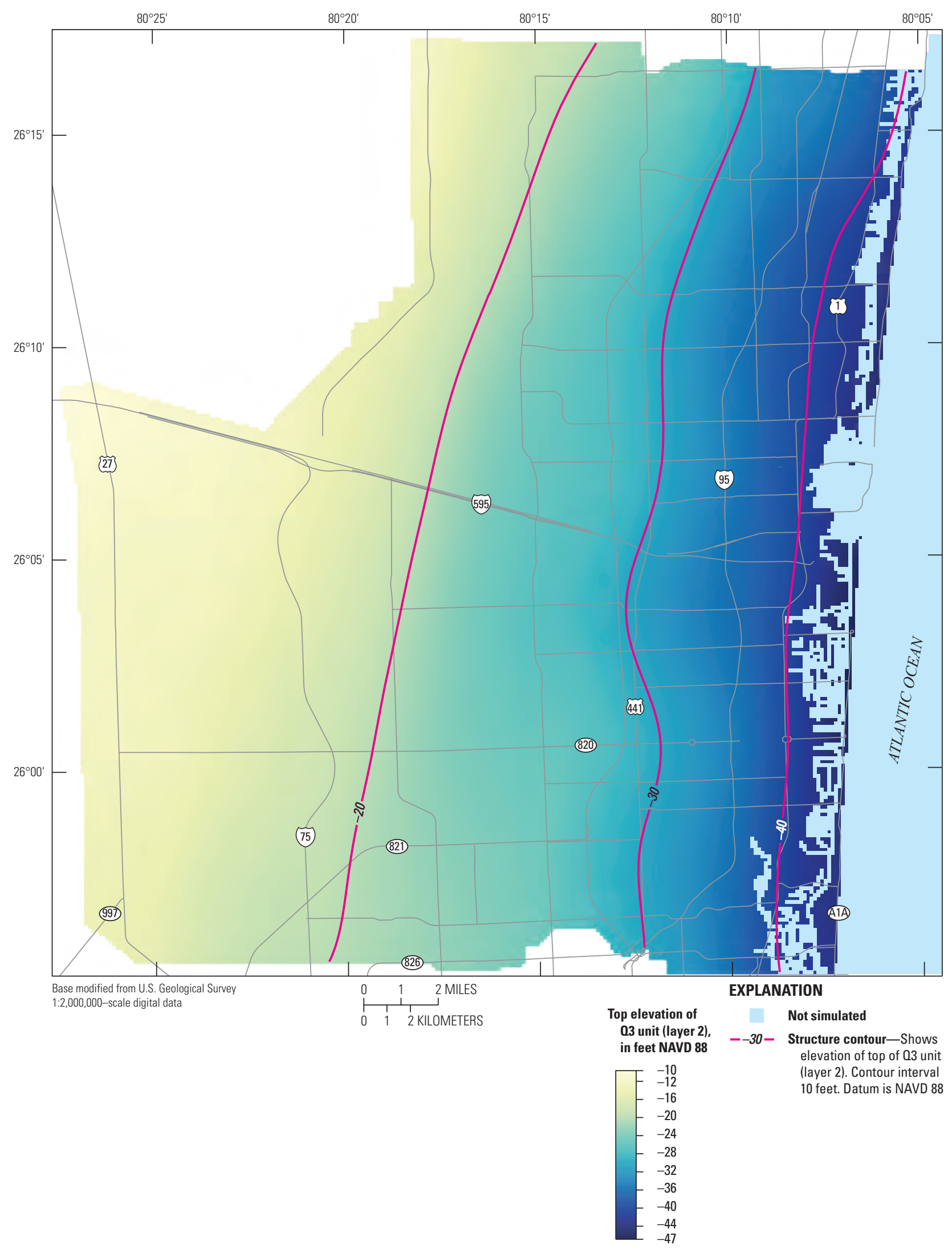

Figure 1-4. Top of 03-unit (layer 2), which corresponds to the bottom of layer 1 (Miami Limestone) in the active part of the model. 


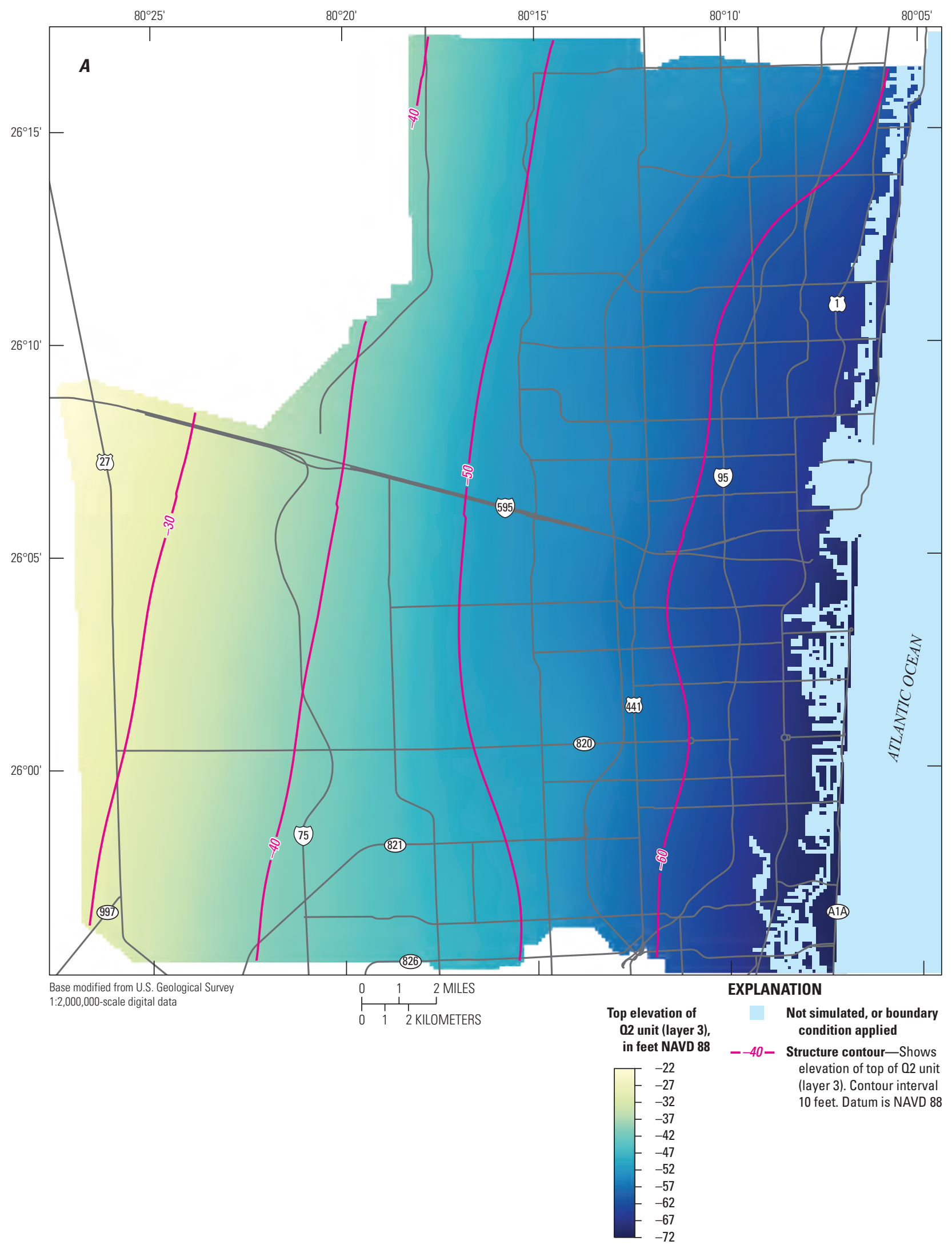

Figure 1-5. A, Top of the 02-unit (layer 3), B, top of the 01-unit (layer 7), and $C$, top of the Pinecrest Sand Member of the Tamiami Formation (layer 11), in the active part of the model. 


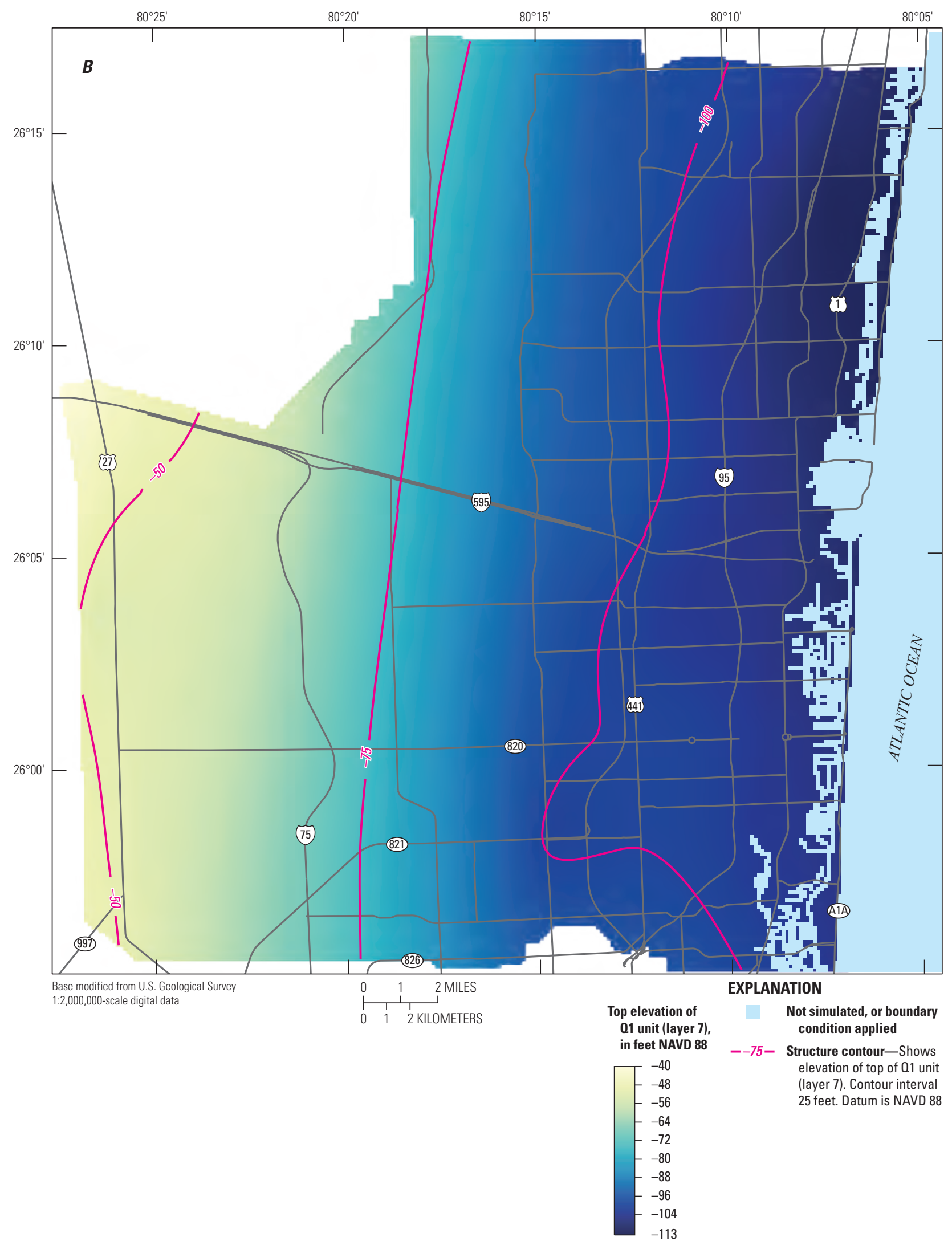

Figure 1-5. A, Top of the 02-unit (layer 3), B, top of the 01-unit (layer 7), and $C$, top of the Pinecrest Sand Member of the Tamiami Formation (layer 11), in the active part of the model.-Continued 
Appendix 1. Model Construction and Calibration

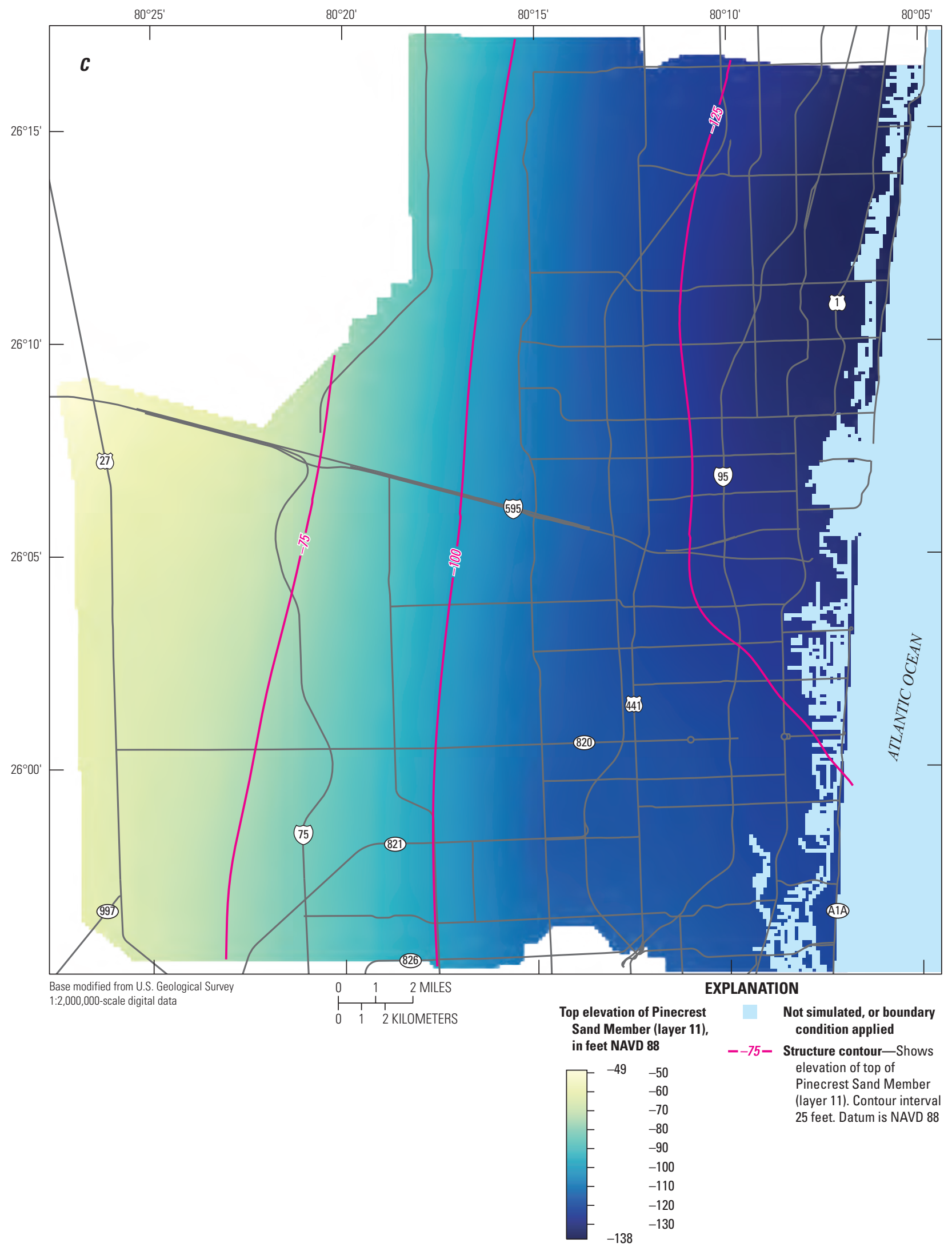

Figure 1-5. A, Top of the 02-unit (layer 3), $B$, top of the 01-unit (layer 7), and $C$, top of the Pinecrest Sand Member of the Tamiami Formation (layer 11), in the active part of the model.-Continued 
The top elevation of the Ochopee Limestone Member of the Tamiami Formation (layer 11) in the active part of the model ranged from -91 to $-179 \mathrm{ft}$ (fig. 1-6A). The base elevation of the Ochopee Limestone (layer 12), which corresponds to the base of the surficial aquifer system in the active part of the model ranged from -143 to $-220 \mathrm{ft}$ (fig. 1-6B).

The thickness of the primary production zone of the Biscayne aquifer (layers 3 to 10) in the active part of the model ranged from 26 to $77 \mathrm{ft}$ (fig. 1-7A). The primary production zone of the Biscayne aquifer is thickest (greater than $75 \mathrm{ft}$ ) near the Pompano well field in the northeast area of the active part of the model. The production zone of the Biscayne aquifer is thickest under the Atlantic Coastal Ridge and Sandy Flatlands, and thins to the east and west away from these features in Broward County (figs. 1-7A and 1-8). The surficial aquifer system (layers 1 to 12 ) in the active part of the model thickens from west to east, ranging from 146 to $237 \mathrm{ft}$ (fig. 1-7B). Three hydrogeologic sections show interpolated top and bottom elevations of each layer in the active part of the model (fig. 1-9). Sections $I-I^{\prime}$ through $K-K^{\prime}$ extend west to east in onshore parts of the model domain (fig. 1-9). The west-to-east cross sections show the general thickening of the Biscayne aquifer and water-table aquifer toward the coast. Model topography and the Biscayne aquifer production zone are also shown on the cross sections. The location of the hydrogeologic section lines are shown on figure 1-1.

The simulation period for the model is January 1950 through May 2012. A total of 749 monthly stress periods were used. A single groundwater flow and transport time step was used during each monthly stress period.

\section{Calibration Approach}

The model was calibrated using automated parameter estimation software (PEST) (Doherty, 2010) using highly parameterized inversion techniques (Doherty and Hunt, 2010). Model parameters were calibrated to data spanning the 42-year period from January 1970 through May 2012. A 20-year warmup period prior to the start of the calibration period was included to reduce the effect on model results of (1) unknown initial conditions and (2) uncertainty in land-use, canal stage, and estimated groundwater pumpage prior to 1970 . The model was calibrated using a combination of head and salinity targets. The use of salinity calibration targets yields more constraint on the solution because they represent targets that are heavily dependent on groundwater fluxes.

\section{Model Parameterization}

An irregular distribution of 185 unique pilot points (Doherty, 2010) was used to parameterize hydraulic properties in the model (fig. 1-10). Using pilot points involves assigning parameter values to a set of these points rather than directly to model cells. Property values are mapped from the pilot points to the model grid using spatial interpolation and result in a smooth variation in property values over the defined interpolation area (Doherty, 2003). The pilot points were separated into coarse and fine groups having 53 and 132 pilot points, respectively. The coarse pilot points were placed on a $15,000-\mathrm{ft} \times 15,000-\mathrm{ft}$ regular grid and cover the entire active domain. The fine pilot points were placed on a 5,000-ft $\times 5,000$ - $\mathrm{ft}$ regular grid and are in the active transport model domain (fig. 1-1). Properties distributed using the coarse pilot points were vertically partitioned into upper (UPR), production (PRD) and lower (LWR) units (fig. 6). The UPR, PRD, and LWR units correspond to layers 1 and 2, layers 3 to 10, and layers 11 and 12, respectively. Properties distributed using the fine pilot points were vertically partitioned into upper production (PD1) and lower production (PD2) units (fig. 6). The PD1 and PD2 units correspond to layers 3 to 6 and layers 7 to 10 , respectively.

Horizontal and vertical hydraulic conductivity were interpolated to the model grid using a combination of coarse and fine pilot points. Porosity was also interpolated to the model grid using a combination of coarse and fine pilot points. Layer 1 was simulated as convertible, whereas all other model layers were simulated as confined. Specific storage $(S s)$ was interpolated to the model grid using the coarse pilot points. The $S s$ of layer 1 was estimated because the surficial aquifer in Water Conservation Areas 2A, 2B, and 3B is frequently inundated by surface water, hence under fully saturated conditions (fig. 1-10). Specific yield (Sy) was interpolated to the model grid for layer 1 using the coarse pilot points, for water-table conditions. 
Pilot points were used as multiplier parameters and assigned an initial value of 1.0 for all properties. During each forward model run, pilot point values were interpolated from pilot point locations to the center of each model grid cell using ordinary kriging. Interpolated coarse and fine pilot-point parameter fields were then proportioned by layer thickness to each layer in the appropriate pilot point unit for each cell. The interpolated multiplier value for each cell was then multiplied by the base property value for that cell. The model property distributions resulting from this operation were used as model inputs. Model parameters for a given cell, $P_{i, j}$, were calculated from pilot point multipliers and base property values by using

$$
P_{i, j}=M_{i, j} \times P_{i, j}^{0}
$$

where

$$
\begin{array}{ll}
M_{i, j} & \text { is the interpolated multiplier for cell } i, j, \text { and } \\
P_{i, j}^{0} & \text { is the base property value for cell } i, j .
\end{array}
$$

Base property values are merely initial values that are adjusted during calibration using pilot point multipliers. The initial property values were assigned reasonable values based on those used in previous hydrologic studies and (or) expected values from literature sources. Given the karstic nature of the Biscayne aquifer and the strong hydraulic connection between the extensive surface-water system and the groundwater system, the ability to extrapolate aquifer performance test (APT) results across large regions of the model domain is limited. Approximate hydraulic conductivity values for the Biscayne aquifer in Broward County range from 75 to $78,000 \mathrm{ft} / \mathrm{d}$ (Fish, 1988), and a median value on the order of thousands of feet per day. As such, a uniform initial (base) hydraulic conductivity of $1,000 \mathrm{ft} / \mathrm{d}$ was assigned to each model layer representing the Biscayne aquifer. This approach reduces potential bias that may result from specifying unsupported property heterogeneity in regions of the active model domain that are not informed by the calibration dataset. A uniform initial (base) hydraulic conductivity of $500 \mathrm{ft} / \mathrm{d}$ was assigned to model layers 1,11 , and 12 , based on the assumption that the hydraulic conductivity of these units is less than that of the Biscayne aquifer.
Few published specific yield, porosity, specific storage, or storage coefficient data exist for the Biscayne aquifer, or other parts of the surficial aquifer system, in Broward County and neighboring Miami-Dade County. Effective porosity, sometimes estimated from total porosity, is used to represent specific yield. Porosity determined in core samples of the Tamiami Formation in Broward County indicate a porosity range from 0.37 to 0.40 (Fish, 1988); median values of porosity for three pore-types differentiated based on Biscayne aquifer core samples from north-central Miami-Dade County range from 0.18 to 0.33 (Cunningham and others, 2006). Effective porosity determined from tracer tests in the Biscayne aquifer in north-central Miami-Dade County ranges from 0.04 to 0.41 (Renken and others, 2008). An intermediate base $S y$ value of 0.20 was assigned to all cells, which is consistent with values used for other models of the Biscayne aquifer (Merritt, 1996; Langevin, 2001; and Brakefield, 2013). Fish (1988) reported two storage coefficient values, $6 \times 10^{-5}$ and $7 \times 10^{-5}$, and one specific storage value, $8 \times 10^{-7} \mathrm{ft}^{-1}$, for the Biscayne aquifer in Broward County. Specific storage values can be approximated from storage coefficient values and depth interval tested, and are on the order of $1 \times 10^{-6}$ to $1 \times 10^{-7}$. Reese and Cunningham (2000) report four storage coefficient values for the underlying gray limestone aquifer, which range from $2 \times 10^{-4}$ to $4 \times 10^{-3}$, and are approximated to specific storage values on the order of $1 \times 10^{-5}$ to $1 \times 10^{-4}$. Thus, an intermediate base $S s$ value of about $3 \times 10^{-5} \mathrm{ft}^{-1}$ was assigned to all cells.

In addition to hydraulic conductivity and storage values, the extinction depth properties used in the MODFLOW Evapotranspiration (EVT) Package were parameterized by using coarse pilot points (fig. 1-10). The conductance for river cell groups was adjusted during calibration, as were monthly rainfall multipliers and monthly potential evapotranspiration multipliers. A total of 156 unique river cell conductance values were adjusted and correspond to grouped canal segments in individual surface-water subbasins. For example, a single river conductance value was applied to $\mathrm{S}-13$ canal segments of identical width between the S-13 and S-13A surface-water control structures. Monthly rainfall multipliers were used to represent a combination of measurement and spatial interpolation errors and sub-grid cell land-surface processes not represented in the model. Extinction depth multipliers were used to represent urban land-use changes on a 10-year basis from 1950 to 2010 . 


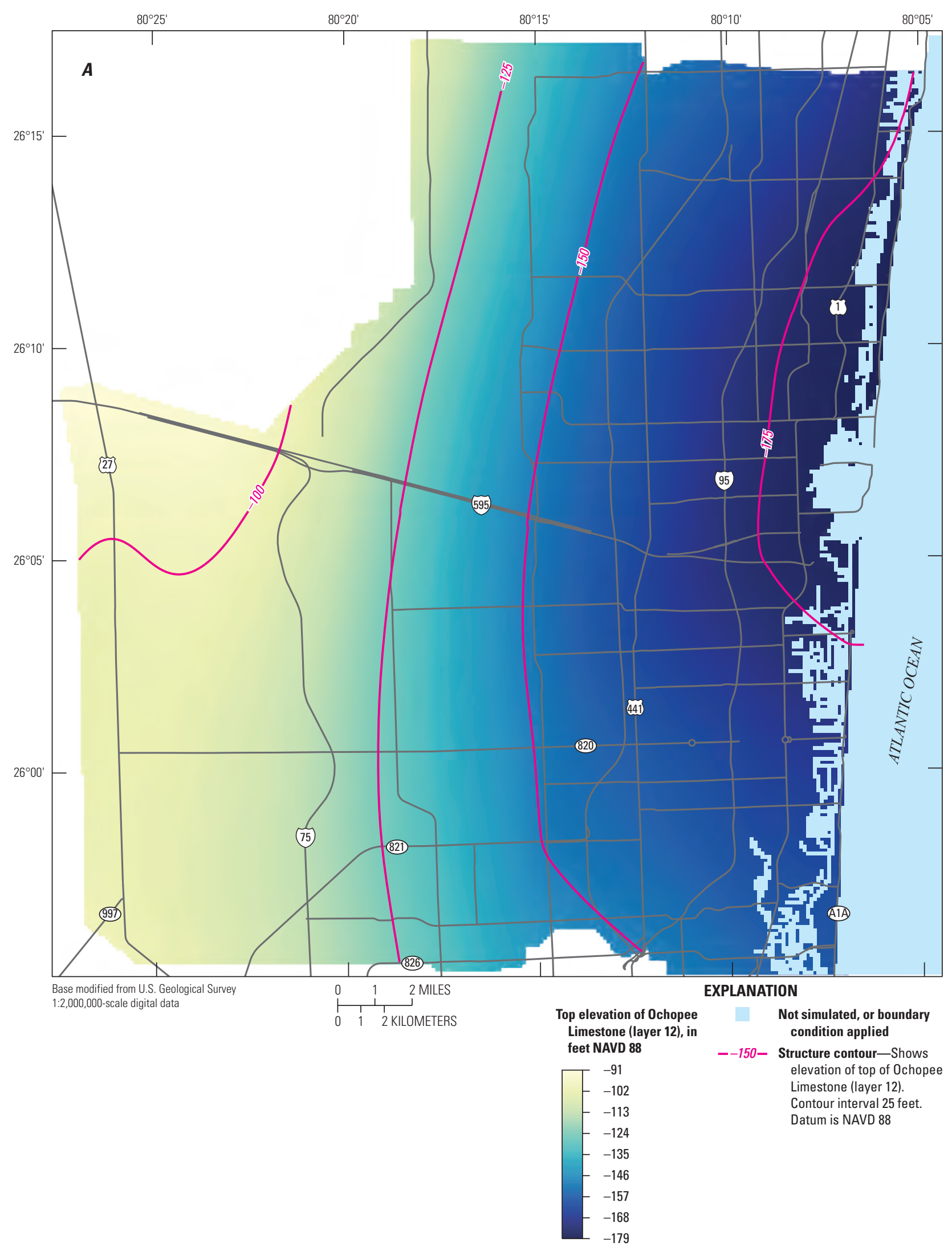

Figure 1-6. $\quad A$, Top (layer 11), and $B$, base (layer 12) of the Ochopee Limestone Member of the Tamiami Formation, in the active part of the model. 


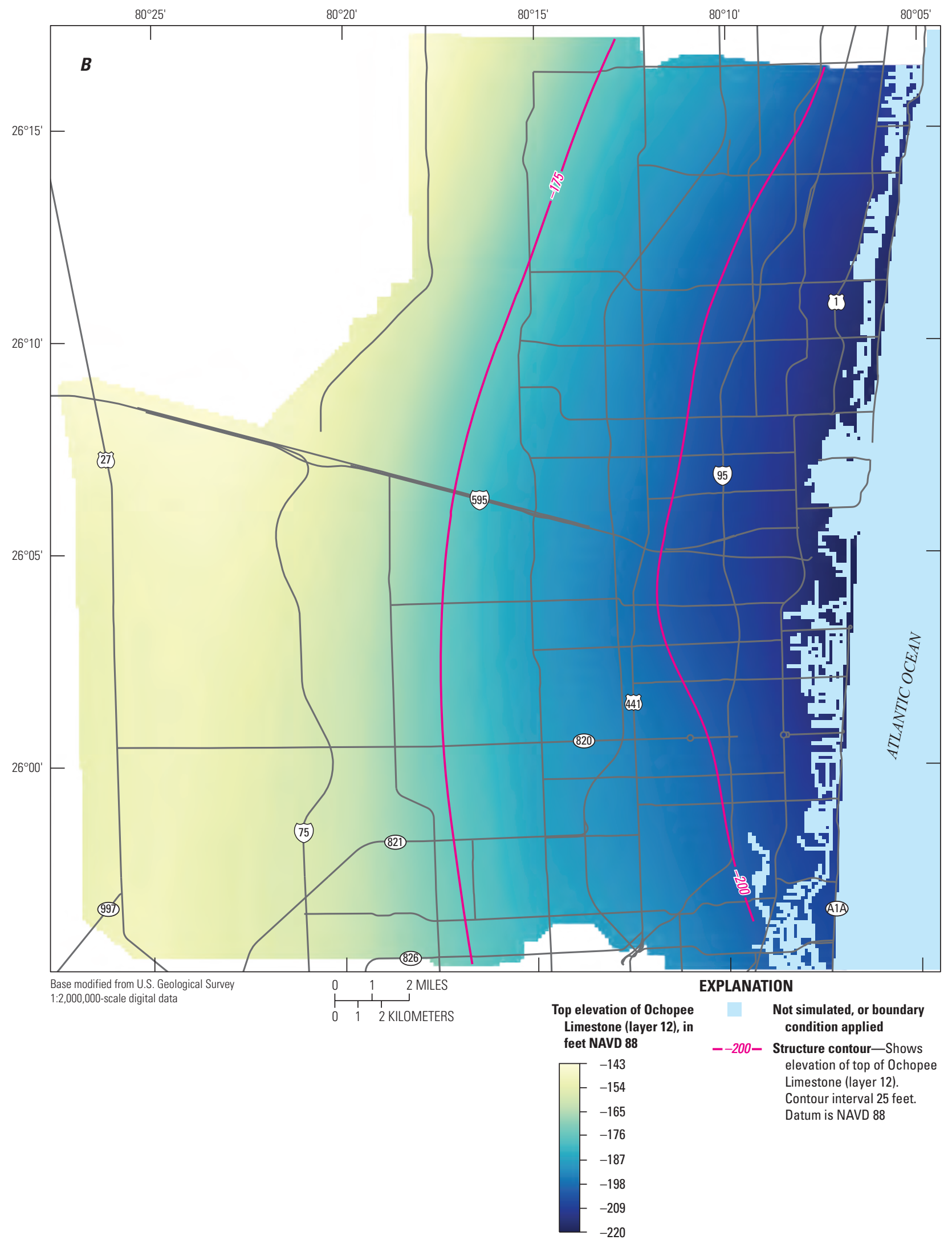

Figure 1-6. A, Top (layer 11), and B, base (layer 12) of the Ochopee Limestone Member of the Tamiami Formation, in the active part of the model.-Continued 


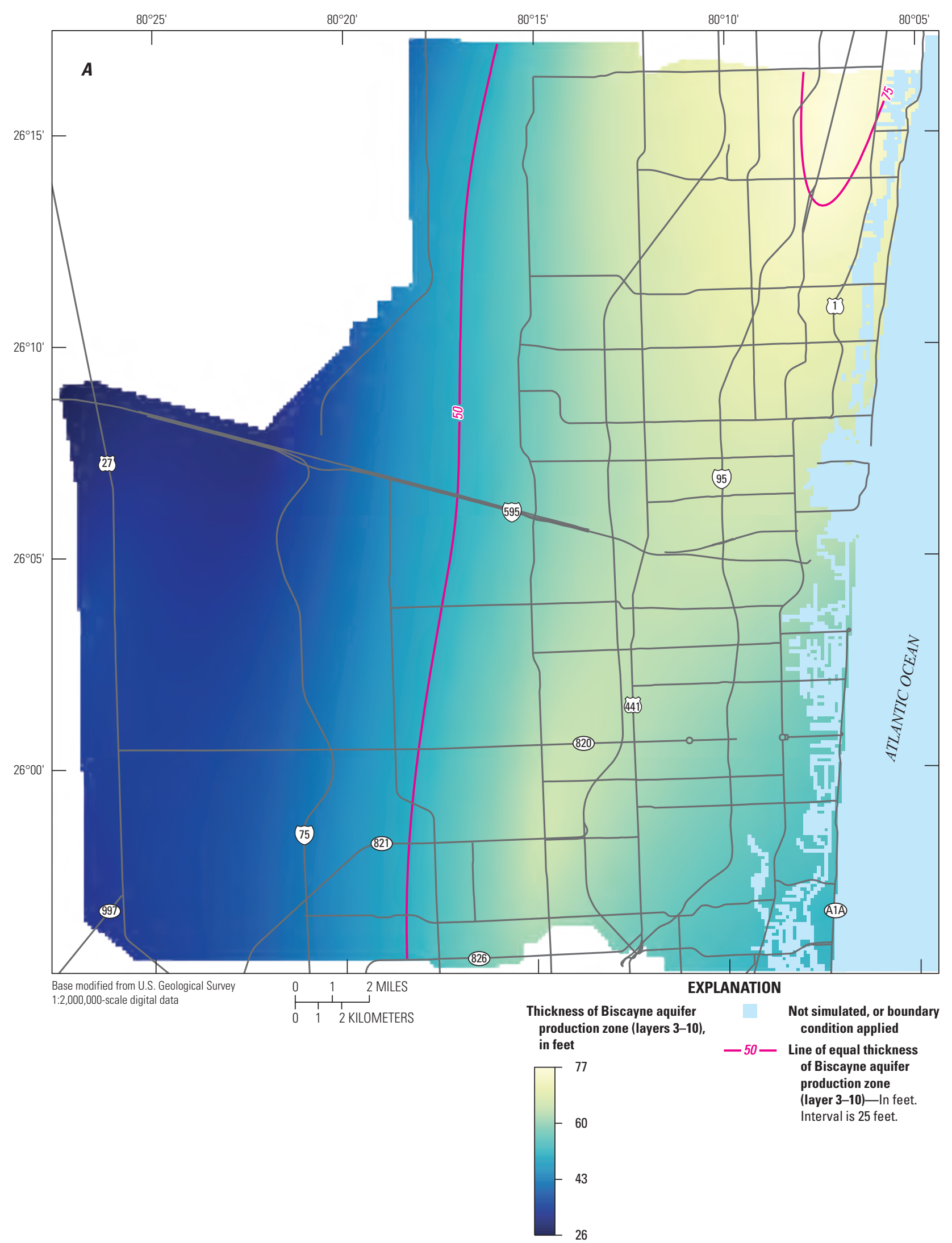

Figure 1-7. $\quad A$, Thickness of the Biscayne aquifer production zone (layers 3 to 10 ) and $B$, the water-table aquifer (layers 1 to 12), in the active part of the model. 


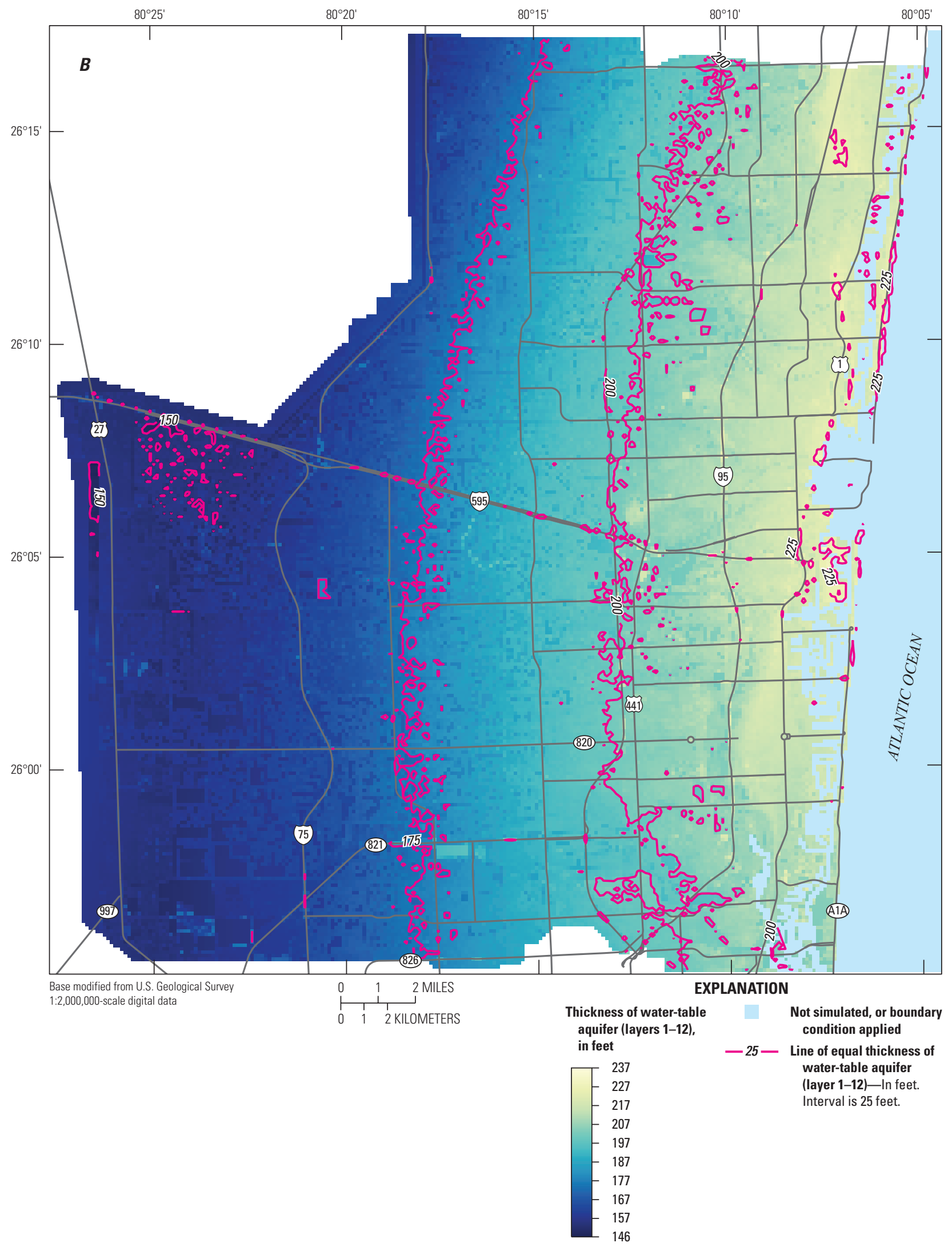

Figure 1-7. A, Thickness of the Biscayne aquifer production zone (layers 3 to 10 ) and $B$, the water-table aquifer (layers 1 to 12), in the active part of the model.-Continued 


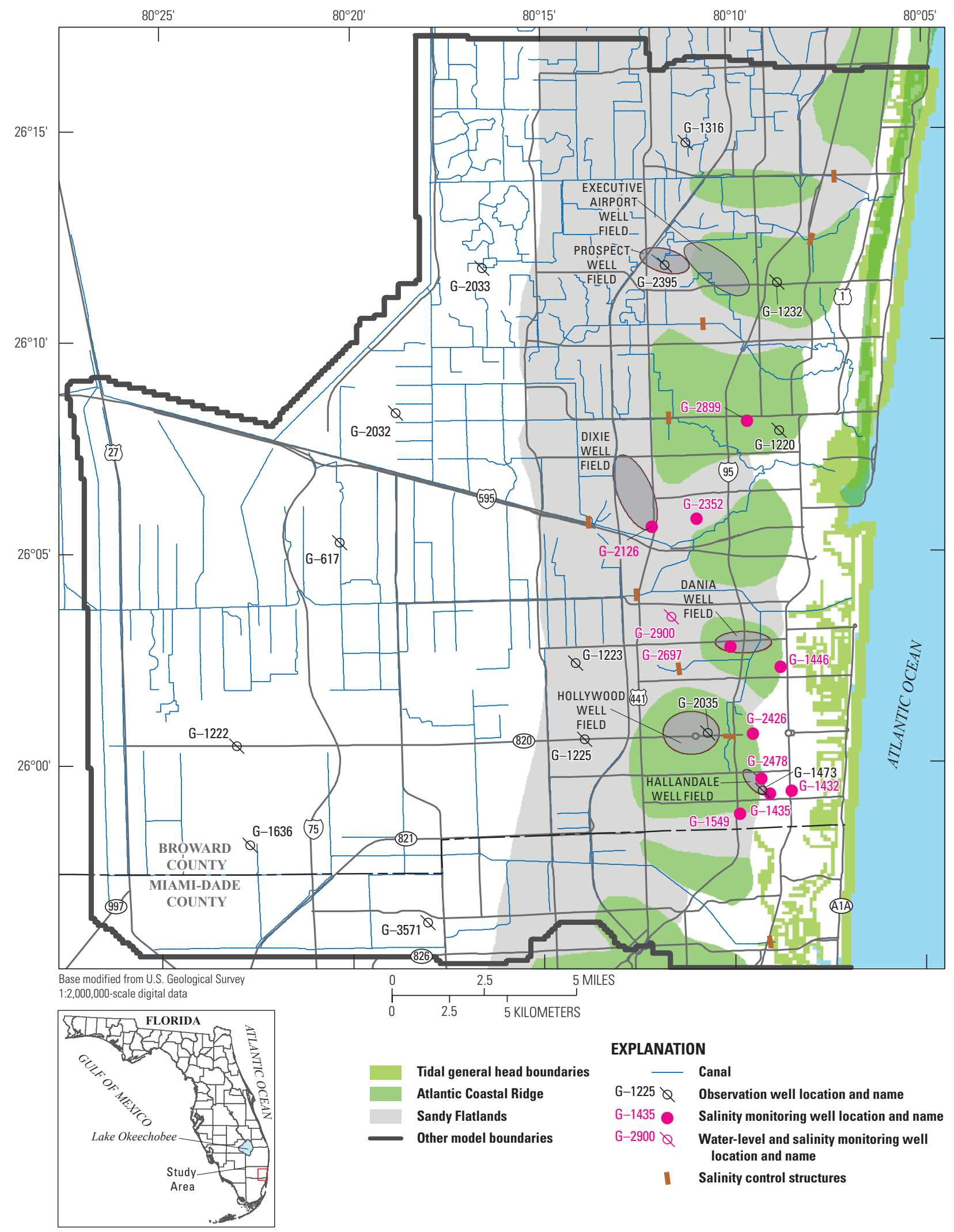

Figure 1-8. Location of Atlantic Coastal Ridge and Sandy Flatlands in the active part of the model. Groundwater level and salinity monitoring-well locations and well identification numbers are also shown. 

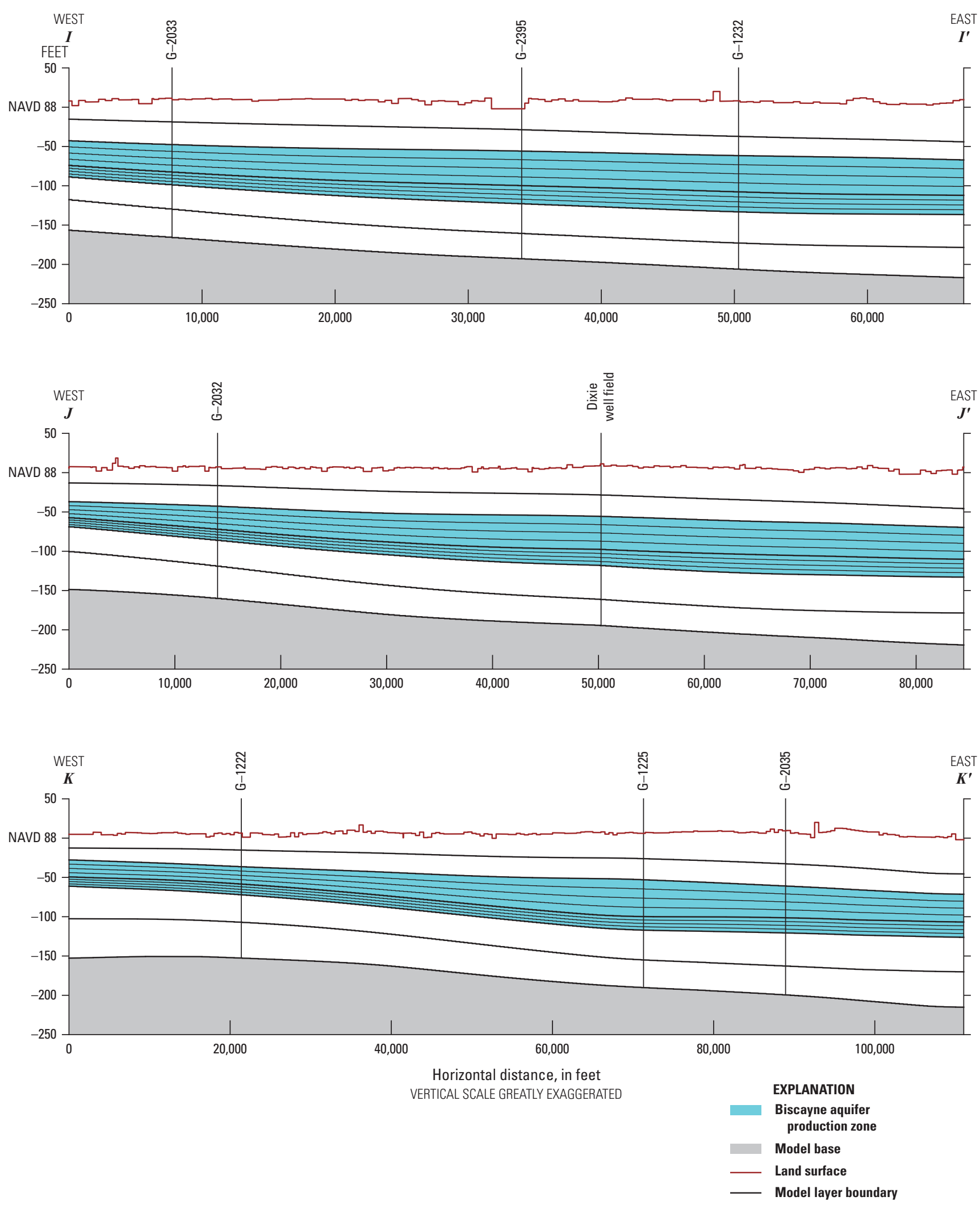

Figure 1-9. Hydrogeologic sections $I-I^{\prime}$ through $K-K^{\prime}$ in the active part of the model. Location of section lines shown in figure 1-1. 


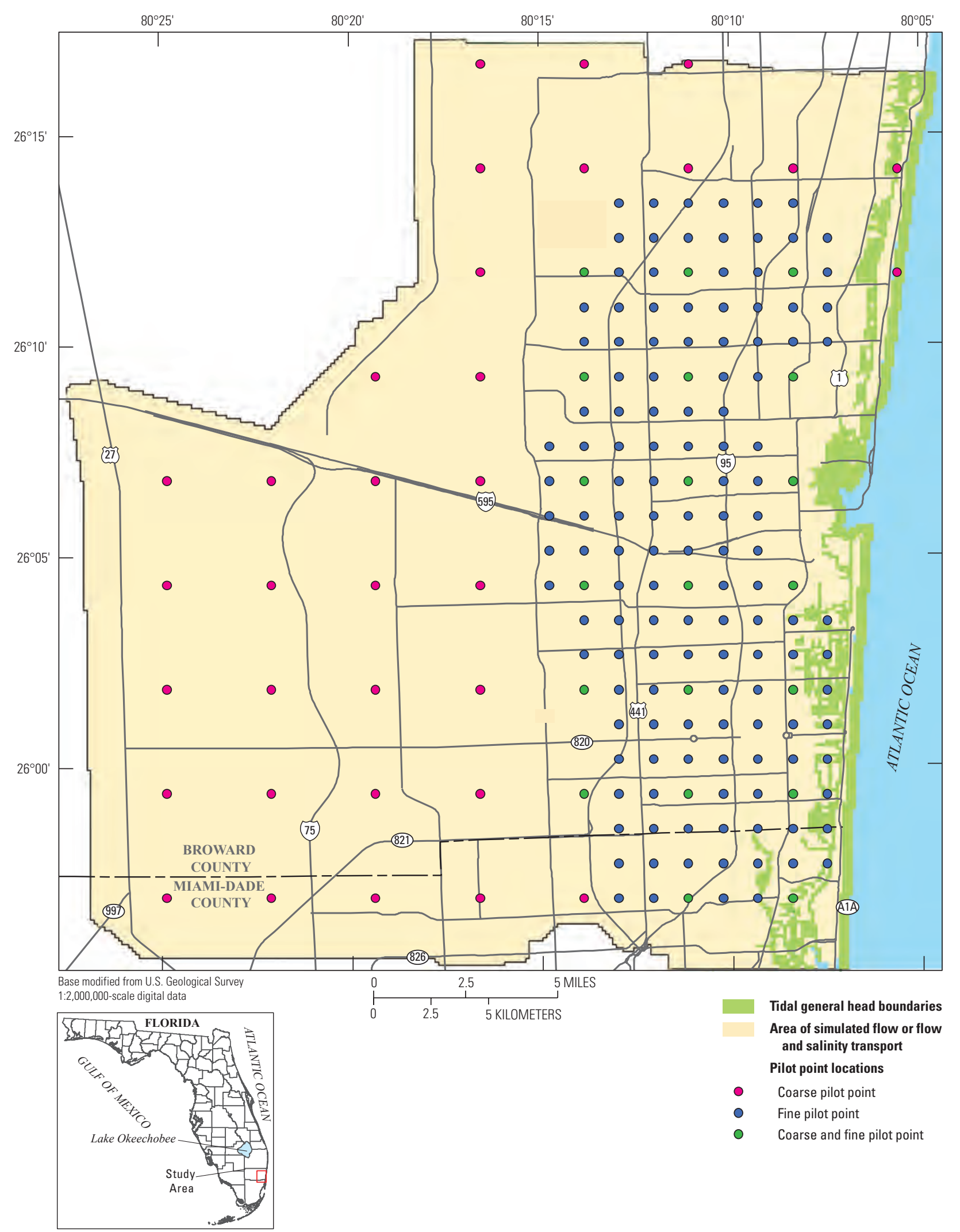

Figure 1-10. Pilot points used to condition select groundwater properties adjusted during model calibration. 
The initial salinity distribution was also adjusted using an approach similar to that of Langevin and Zygnerski (2013). An initial stable freshwater-saltwater interface position was developed by running the model forward 200 years reusing the 1950-52 stresses. Then the utility software CONC2ELEV (Doherty, 2010) was used to define an interface elevation distribution for the active model domain. During subsequent calibration model runs, pilot-point multiplier parameters were used to adjust the interface elevation distribution, and the utility software ELEV2CONC (Doherty, 2010) was used to translate the pilot-point-modified interface elevation distribution into initial concentration distributions for use in the model.

A total of 1,842 parameters were adjusted during calibration. Truncated singular value decomposition was used to reduce the number of parameters estimated during each calibration iteration by combining nonorthogonal parameters into linear combinations of parameters (Aster and others, 2005). Tikhonov regularization (Tikhonov and Arsenin, 1977) was also used to reduce deviations of parameters from initial values. This formulation yields parameter distributions that provide an acceptable fit between model output and observation data, while simultaneously minimizing deviations from preferred values based on field measurements and expert knowledge.

\section{Calibration Targets}

The calibration process was constrained by water-level data from 15 groundwater monitoring wells and water-quality data from 11 groundwater monitoring wells (fig. 1-8, table 1-2), and chloride concentrations at the following well fields:

- Broward County 1A, 3A, and 3B;

- Dixie, Executive Airport and Prospect;

- Dania;

- Hollywood; and

- Hallandale.

Chloride concentrations in individual pumping wells were used as calibration targets if pumping rates were available. Prior to the availability of pumping rates for individual wells, flow-weighted chloride concentration well-field targets were used. By assuming the background concentration of chloride in the aquifer landward of the saltwater-freshwater interface is zero $\mathrm{mg} / \mathrm{L}$, the individual well chloride concentration target was assumed to be zero $\mathrm{mg} / \mathrm{L}$ for all individual pumping wells within each well field. This approach helps to prevent over estimation of chloride concentrations in each well field.

\section{Salinity}

A particular concern for groundwater management is long-term viability of well fields that supply fresh drinking water. Thus, the most critical response for model simulation is the transition between background and elevated salinity as the saltwater interface approaches and moves past public-supply well fields. The transition starts to occur between 100 and $1,000 \mathrm{mg} / \mathrm{L}$ chloride (depending on background salinity) and levels out between 1,000 and $10,000 \mathrm{mg} / \mathrm{L}$ chloride (fig. 14A). Spatially, the transition occurs near the front (landward edge) of the saltwater-freshwater interface; delineating the transition accurately is dependent on monitoring-well distribution and density. Salinity data selected for calibration were those that likely show transition of the interface during the period of record (for example, G-1435 or G-2478 show the most complete transition) or physically bracket the interface on either the freshwater (G-2426) or saltwater side (G-2697, G-2900) (fig. 14A). Note that length of record and spatial distribution of sites for which salinity data were collected limit the available information about the movement and location of the saltwater-freshwater interface, and thus how closely the model can be calibrated. Salinity values, recorded as either chloride concentration or specific conductance, vary over several orders of magnitude. Furthermore, short-term fluctuations in salinity that are superimposed on longer-term trends, such as monthly fluctuations superimposed on multiyear fluctuations like those at G-2426 and G-2900, were not considered in the model calibration because they do not reflect the overall movement of the saltwater-freshwater interface.

Short-term fluctuations may represent fluctuations in groundwater level in response to seasonal or local processes such as recharge, which dilutes salinity; pumping, which can draw either more or less saline water toward the well; or natural variability in groundwater salinity. To capture the longer-term trends in salinity, the model was calibrated to salinity, normalized as a fraction of seawater, and transformed into 180-day moving averages for the 11 selected wells for groundwater salinity monitoring (fig. 1-8).

\section{Groundwater Levels}

The model was calibrated to monthly groundwater levels at 15 sites (fig. 1-8), selected for length and continuity of record and a broad areal distribution. Daily data for the selected sites were acquired from the U.S. Geological Survey (USGS) National Water Information System (NWIS) (U.S. Geological Survey, 2014). For each site, each monthly value was calculated by averaging the daily value of the last day of the month, and the 15 previous and following daily values. Thus, the observation value is intended to represent the average value at the end of the month and the conditions resulting from the stresses applied during the month. 


\section{Potential Effects of Alterations to the Hydrologic System on the Distribution of Salinity in the Biscayne Aquifer}

Table 1-2. Site information and type of data used for salinity and water-level calibration, and other sites.

[USGS, U.S. Geological Survey; horizontal datum is North American Datum of 1983; X, type of data used from this site; -, not available, or type of data not used from this site]

\begin{tabular}{|c|c|c|c|c|c|c|c|}
\hline \multirow{2}{*}{$\begin{array}{l}\text { Station } \\
\text { name }\end{array}$} & \multirow{2}{*}{$\begin{array}{l}\text { USGS well } \\
\text { identification }\end{array}$} & \multirow{2}{*}{$\begin{array}{c}\text { Latitude, } \\
\text { in decimal } \\
\text { degrees }\end{array}$} & \multirow{2}{*}{$\begin{array}{c}\text { Longitude, } \\
\text { in decimal } \\
\text { degrees }\end{array}$} & \multicolumn{3}{|c|}{ Type of data } & \multirow{2}{*}{$\begin{array}{c}\text { Used in } \\
\text { calibration }\end{array}$} \\
\hline & & & & Water level & Chloride & Induction log & \\
\hline $\mathrm{G}-617$ & 260515080202101 & 26.0877 & -80.3385 & $\mathrm{X}$ & - & - & Yes \\
\hline $\mathrm{G}-1220$ & 260752080084701 & 26.1310 & -80.1462 & $\mathrm{X}$ & - & - & Yes \\
\hline G-1222 & 260025080230401 & 26.0073 & -80.3842 & $\mathrm{X}$ & - & - & Yes \\
\hline G-1223 & 260219080141101 & 26.0393 & -80.2361 & $\mathrm{X}$ & - & - & Yes \\
\hline G-1225 & 260032080135701 & 26.0092 & -80.2322 & $\mathrm{X}$ & - & - & Yes \\
\hline $\mathrm{G}-1232$ & 261122080083401 & 26.1895 & -80.1467 & $\mathrm{X}$ & - & - & Yes \\
\hline G-1316 & 261441080111301 & 26.2448 & -80.1865 & $\mathrm{X}$ & - & - & Yes \\
\hline G-1432 & 255917080083201 & 25.9884 & -80.1419 & - & $\mathrm{X}$ & - & Yes \\
\hline G-1435 & 255916080090401 & 25.9878 & -80.1512 & - & $\mathrm{X}$ & - & Yes \\
\hline G-1446 & 260213080084801 & 26.0373 & -80.1464 & - & $\mathrm{X}$ & - & Yes \\
\hline G-1473 & 255918080091801 & 25.9887 & -80.1547 & $\mathrm{X}$ & - & - & Yes \\
\hline G-1549 & 255845080095301 & 25.9795 & -80.1644 & - & $\mathrm{X}$ & - & Yes \\
\hline G-1636 & 255807080224301 & 25.9685 & -80.3784 & $\mathrm{X}$ & - & - & Yes \\
\hline G-2032 & 260821080185101 & 26.1386 & -80.3138 & $\mathrm{X}$ & - & - & Yes \\
\hline G-2033 & 261141080163401 & 26.1956 & -80.2759 & $\mathrm{X}$ & - & - & Yes \\
\hline G-2035 & 260040080104401 & 26.0114 & -80.1786 & $X$ & - & - & Yes \\
\hline G-2126 & 260533080121001 & 26.0928 & -80.2025 & - & $\mathrm{X}$ & - & Yes \\
\hline G-2352 & 260547080105801 & 26.0964 & -80.1826 & - & $\mathrm{X}$ & - & Yes \\
\hline G-2395 & 261147080114501 & 26.1965 & -80.1958 & $\mathrm{X}$ & - & - & Yes \\
\hline $\mathrm{G}-2426$ & 260041080093102 & 26.0115 & -80.1585 & - & $\mathrm{X}$ & - & Yes \\
\hline G-2478 & 255936080091702 & 25.9937 & -80.1549 & - & $\mathrm{X}$ & - & Yes \\
\hline G-2697 & 260242080101101 & 26.0458 & -80.1681 & - & $\mathrm{X}$ & - & Yes \\
\hline G-2896 & 261304080072501 & 26.2182 & -80.1235 & - & - & $\mathrm{X}$ & No \\
\hline G-2899 & 260804080092701 & 26.1348 & -80.1603 & - & $\mathrm{X}$ & - & Yes \\
\hline G-2900 & 260325080113901 & 26.0577 & -80.1938 & $\mathrm{X}$ & $\mathrm{X}$ & $\mathrm{X}$ & Yes \\
\hline G-2903 & 255843080090901 & 25.9791 & -80.1522 & - & - & $\mathrm{X}$ & No \\
\hline G-2921 & 260326080120301 & 26.0575 & -80.2008 & - & - & $\mathrm{X}$ & No \\
\hline G-3571 & 255616080180301 & 25.9377 & -80.3009 & $\mathrm{X}$ & - & - & Yes \\
\hline
\end{tabular}




\section{Model Calibration}

Model calibration involves modifying model properties, or input parameters (for example, storage, porosity, or hydraulic conductivity), to estimate unknown physical properties and (or) state conditions. During model calibration, selected model input parameters are modified until differences between simulation results and observations (model error) are reduced to an acceptable level. The combination of the inherent variability of physical systems and limited observation data in most settings makes it possible to achieve multiple, similar, and acceptable levels of fit with the observation data using different (non-unique) model parameter datasets.

Mathematically, the process of model calibration involves modifying selected model input parameters to solve an inverse problem by minimizing any misfit with observation data. Parameter modifications are determined on the basis of model response to parameter changes (sensitivities) at observation locations. Because the solution of the inverse problem for physical systems having limited observation data is typically non-unique, an infinite number of parameter combinations will produce models that meet acceptable calibration criteria (Moore and Doherty, 2005). Additionally, if the number of parameters is greater than the number of observations, the inverse problem will be difficult to solve and is considered ill-posed. The process of reducing the number of parameters to form a well-posed inverse problem having a unique solution is known as regularization (Vogel, 2002). Traditional, over-determined inverse problem formulation, commonly achieved by using zone-based parameterization, reduces the number of parameters prior to calibration to find a unique solution. Under-determined (highly parameterized) problem formulations rely on mathematical regularization (Tikhonov and Arsenin, 1977) to find a unique solution and enforce expert knowledge (Aster and others, 2005). Given the known heterogeneity of Biscayne aquifer hydraulic properties, highly parameterized approaches (Doherty and Hunt, 2010; Doherty and others, 2010a, b) were used to calibrate the model. Highly parameterized inversion allows for greater flexibility in the inverse problem so that more information in the observation data can be used to condition model parameters while also removing the need to discretize model properties in piecewise constant zones before the calibration process.

The model was calibrated using PEST, version 12.1 (Doherty, 2010). PEST uses a variant of the Gauss-Newton algorithm with the Marquardt-Levenburg trust region (Marquardt, 1963). The PEST algorithm seeks the minimum of a weighted L-2 norm objective function by applying a multidimensional form of Newton's method using a first-order approximation to the Hessian matrix (Oliver and others, 2008). A form of the weighted L-2 norm objective function minimized by PEST during the calibration process using the Gauss-Newton algorithm with the Marquardt-Levenburg trust region algorithm is

$$
\Phi=\sum_{i=1}^{n}\left(w_{i} r_{i}\right)^{2}=\sum_{i=1}^{n}\left(w_{i}\left[s_{i}-o_{i}\right]\right)^{2}
$$

where

$\Phi \quad$ is the weighted L-2 norm objective function,

$n \quad$ is the number of observations,

$w_{i} \quad$ is the weight of observation $i$,

$r_{i} \quad$ is the residual of observation $i$,

$s_{i} \quad$ is the simulated value of observation $i$, and

$o_{i} \quad$ is the measured value of observation $i$.

Minimization of the objective function using the GaussNewton algorithm with the Marquardt-Levenburg trust region algorithm can be time consuming because it requires repeated formulation of a Jacobian matrix, calculated using finite-difference first derivatives. The subspace dimensionality-reduction approach, known as SVD-Assist (Tonkin and Doherty, 2005), was used to further reduce the computational burden related to formulating the Jacobian matrix and subsequently solving of the linear system of equations.

A total of 14,516 observations were used for the calibration. A subjective weighting scheme based on expert knowledge was used to form a composite objective function that focuses the calibration on reproducing the components of the observation dataset that most resemble what the model is intended to predict (Doherty and Welter, 2010). Weights were assigned so that processed salinity observations accounted for 33 percent of the initial objective function, processed groundwater levels accounted for 17 percent of the initial objection function, and well-field concentrations accounted for 50 percent of the initial objection function. The monthly salinity observations at the well fields were assigned a relatively large weight so that they could contribute substantially to the composite objective function. Without such weighting, the large number of groundwater level and salinity observations would reduce the contribution of the monthly well-field concentration observations to the overall composite objective function and their associated influence on parameter adjustments during the inversion process.

\section{Boundary Conditions}

Boundary conditions for the model include specified heads, specified fluxes, and head-dependent fluxes. Specified heads represent the correspondence of groundwater heads and Atlantic Ocean tidal stages in offshore areas. Specified fluxes include rainfall and groundwater pumpage. Head-dependent fluxes include evapotranspiration, brackish surface-water boundaries representing the Intracoastal Waterway and tidal finger canals, surface-water canal leakage, groundwater flow across the northern and southern edges of the model, and groundwater flow from the water conservation areas. The base of the surficial aquifer (model layer 12) was defined as 
a no-flow boundary, which prevents water flow and salinity transport across the boundary. A portion of the northern and southern edges of the model were also defined as a no-flow boundary (fig. 1-11).

\section{Specified Heads and Fluxes}

Model cells representing the Atlantic Ocean were simulated using time-variant specified head (CHD) (Harbaugh and others, 2000) boundaries in all model layers (fig. 1-11). The average monthly tidal-stage data, based on a composite of data collected at the Miami Beach (Station ID 8723170; latitude: 25 46.1; longitude: 80 7.9), Haulover Pier (Station ID 8723080; latitude: 25 54.2; longitude: 80 7.2), and Virginia Key (Station ID 8723214; latitude: 25 43.9; longitude: 80 9.7) tidal stations (National Oceanic and Atmospheric Administration, 2012) (fig. 3), were used to define the head in each model cell underlying the Atlantic Ocean. Each specified head cell was specified to have the salinity of seawater.

\section{Rainfall}

Rainfall was applied to the uppermost active model cell using the MODFLOW Recharge (RCH) Package. Daily rainfall data calculated from Next Generation Radar (NEXRAD) return-intensity data are available from the SFWMD on a $1.24 \times 1.24$-mi grid in the model domain for the period from 1996 through 2012. Prior to 1996, point measurements of daily rainfall are available. Recharge was specified to have the salinity of freshwater.

NEXRAD return-intensity data collected in the study area by the National Weather Service (NWS) are corrected to account for blockage caused by obstructions (clutter suppression) and then converted to precipitation by Weather Services Incorporated (WSI) using an empirical lookup table. The WSI NEXRAD rainfall data are further refined by the One Rain Company through a gage-correction procedure to produce the final rainfall dataset available from the SFWMD. More detail on the methods used to convert raw NWS NEXRAD return-intensity data to gage-corrected rainfall data in the study area are provided in Skinner and others (2009).

Selected rain gages maintained by the SFWMD are used in the gage-correction procedure; as a result, there may be discrepancies between NEXRAD rainfall data and data from rain gages not included in the gage-correction procedure. Systematic and temporal biases between the two sources of rainfall data have been observed elsewhere (for example, Neary and others, 2004; Wang and others, 2007; and Watkins and others, 2007). Skinner and others (2009) determined that north of Lake Okeechobee (fig. 1), NEXRAD rainfall data were a factor of 0.95 less than gage data, on average. Furthermore, Skinner and others (2009) determined that the NEXRAD rainfall data tended to overestimate actual rainfall amounts of less than $0.5 \mathrm{inch}$ (in.) and underestimate rainfall amounts greater than $1.0 \mathrm{in}$.

From 1996 through 2012, area-weighted, monthly NEXRAD rainfall depths were calculated for each model grid cell. Monthly NEXRAD data from 1996 through 2012 were used to calculate monthly ordinary kriging factors that were used to interpolate point rainfall data to the model grid prior to 1996. The locations of NOAA rain gages used prior to 1996 are shown in figure 1-11. NOAA rain gages were excluded from the monthly interpolation process if their data were not available for a specific month. Monthly rainfall rates were adjusted during model calibration using monthly multipliers to improve model fit (table 1-3). In addition to potential bias in the NEXRAD rainfall data, monthly rainfall multipliers also correct the rainfall data for processes not represented in the model, such as surface-water runoff and temporary storage of water on the landscape. Unadjusted rates of average annual rainfall for the active model domain range from $37.2 \mathrm{in} / \mathrm{yr}$ (1989) to $106.6 \mathrm{in} / \mathrm{yr}$ (1953) and average $61.8 \mathrm{in} / \mathrm{yr}$ for the period from 1950 through 2012 (fig. 7). Adjusted rates of average annual rainfall for the active model domain range from $34.7 \mathrm{in} / \mathrm{yr}$ (1989) to $99.5 \mathrm{in} / \mathrm{yr}$ (1953) and average $57.7 \mathrm{in} / \mathrm{yr}$ for the period from 1950 through 2012.

\section{Groundwater Pumping}

A total of 300 wells in 34 well fields are included in the model using the MODFLOW Well (WEL) Package. The majority of the groundwater pumpage is withdrawn from layers 2 to 10 , with a small percentage withdrawn from layer 11. Well location, construction, and pumping-rate data were used to assign spatial and temporal pumping distributions to specific cells in the model. For a given well, pumping stresses were distributed vertically and pumping rates were applied equally among all model layers for which more than 50 percent of the vertical height of a layer intersected the open interval of that well. Pumping rate and well location data were compiled from reported groundwater pumping rates values (D. Rickabus, South Florida Water Management District, written commun. October 2012), well construction and abandonment data (Katie Lelis, Broward County, written commun., October 2012), and published estimated values

Table 1-3. Calibrated monthly rainfall multipliers.

\begin{tabular}{cccccccccccccc}
\hline \multicolumn{10}{c}{ Month } \\
\hline $\mathbf{1}$ & $\mathbf{2}$ & $\mathbf{3}$ & $\mathbf{4}$ & $\mathbf{5}$ & $\mathbf{6}$ & $\mathbf{7}$ & $\mathbf{8}$ & $\mathbf{9}$ & $\mathbf{1 0}$ & $\mathbf{1 1}$ & $\mathbf{1 2}$ \\
\hline 1.04 & 1.10 & 1.11 & 0.93 & 1.28 & 0.95 & 0.88 & 0.94 & 0.85 & 0.74 & 0.71 & 0.68 \\
\hline
\end{tabular}




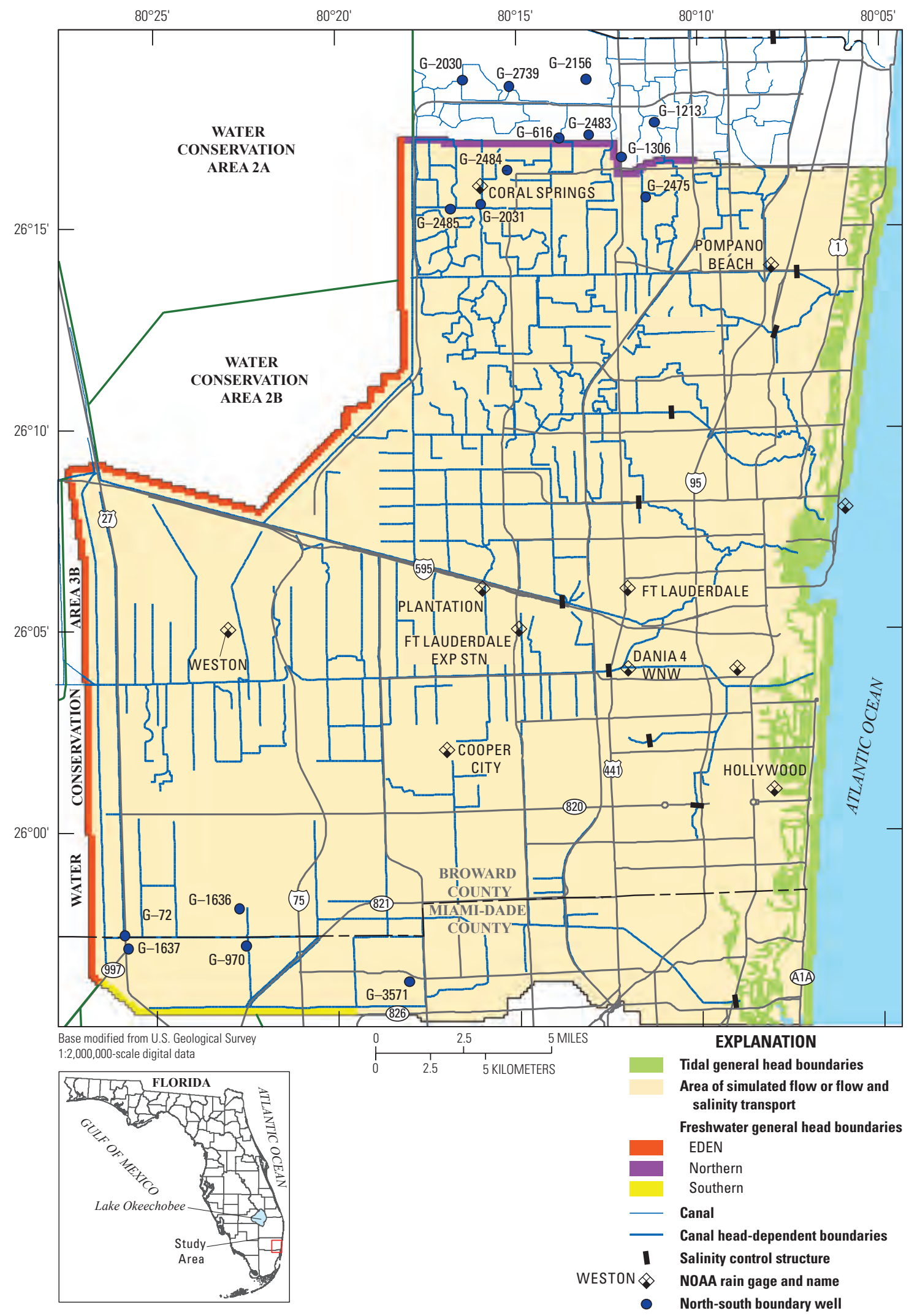

Figure 1-11. Location of no-flow, specified head, and head-dependent groundwater boundary conditions. Also shown are the location of groundwater observation wells used to define the northern and southern general head boundaries and National Oceanic and Atmospheric Administration (NOAA) rain gages used to develop interpolated rainfall data prior to 1996. [EDEN, Everglades Depth Estimation Network] 
(Marella, 1988, 1992, 1995, 1999, 2004, 2009, 2014). The quality and completeness of pumping records has changed through time. Before 1977, pumping records were incomplete, poorly organized, or not available. Since 1977, when reporting requirements changed, information about pumping distribution has become increasingly detailed. Initially, pumping was reported as total permitted rate, which could include multiple wells and multiple well fields. Later, pumping was reported as total rate per well field, and ultimately as total per well. During the study period, new wells were constructed and existing wells were abandoned, and these records were used to spatially redistribute pumping accordingly.

The 1950 to 1977 pumping distribution was estimated using census data, well construction data, and per capita estimates for the State of Florida. For each municipality with a water-supply system, the population for each 5-year period from 1950 through 1975, and for the 2-year period from 1976 through 1977, was multiplied by an estimated per capita use for Florida for that period from Marella (2014). The resulting total public-supply pumping values for each municipality were distributed among known well locations within that municipality. The relation between population and per-capita water use for Broward County is shown in figure 4.

From 1977 to 2012, permitted pumping rates were distributed on a monthly basis between known locations of wells listed in a given permit, at a specified well field, or at a specific well. If permitted pumping rates were known for individual wells, those rates were applied at each well location. If permitted rates were known only for the well field, the rates were distributed equally between wells in the well field. Lastly, if permitted rates were known only for the permit as a whole, which might include multiple well fields, the rates were distributed equally among wells listed in the permit.

For the period from 1950 to 1954 , the total monthly groundwater pumpage applied in the active model area ranged from 173.4 to 211.3 million gallons per month (Mgal $/ \mathrm{mo})$ (fig. 8). From 1955 to 1959, the total monthly groundwater pumpage applied in the active model area ranged from 460.8 to $641.5 \mathrm{Mgal} / \mathrm{mo}$. From 1960 to 1964 , the total monthly groundwater pumpage applied in the active model area ranged from 894.7 to $1,125.9 \mathrm{Mgal} / \mathrm{mo}$. From 1965 to 1969 , the total monthly groundwater pumpage applied in the active model area ranged from 1,009 to $1274.7 \mathrm{Mgal} / \mathrm{mo}$. From 1970 to 1974, the total monthly groundwater pumpage applied in the active model area ranged from 2,344.9 to 3,070.4 Mgal/mo. After 1975, the total monthly groundwater pumpage applied in the active model area ranged from 3,657.9 to $9,104.7 \mathrm{Mgal} / \mathrm{mo}$. Total monthly groundwater pumping peaked at 9,104.7 Mgal/mo in April 2006. In general, groundwater pumpage increased from 1950 through April 2006 and has decreased since then.

\section{Head-Dependent Boundaries}

Evapotranspiration, leakage to and from canals and tidal water-ways, leakage from the conservation areas, and lateral fluxes across the northwestern and southwestern edges of the model were simulated using head-dependent boundary conditions.

\section{Evapotranspiration and Net Recharge}

The MODFLOW Evapotranspiration (EVT) Package was used to simulate evapotranspiration from the active model domain (Harbaugh and others, 2000). Daily, GOES-based reference evapotranspiration data are available on a $1.24-\mathrm{mi} \times 1.24-\mathrm{mi}$ grid in the model domain for the period from 1996 through 2012 (Jacobs and others, 2008). Prior to 1996, point measurements of daily reference evapotranspiration are available.

From 1996 through 2012, area-weighted, monthly, GOES-based reference evapotranspiration rates were calculated for each model grid cell. Monthly, GOES-based reference evapotranspiration rates from 1996 through 2011 were used to calculate monthly averages. Average monthly values for the 1996 through 2011 period were used for the appropriate month for the period from 1950 through 1995. For example, each January value from 1950 through 1995 is identical for a given cell.

The EVT Package evapotranspiration surface (SURF) was specified to be equal to land surface (fig. 1-3) and defines the elevation at which the specified evapotranspiration rates are applied in cells when water levels are greater than or equal to this elevation. A base EVT Package extinction depth (EXDP), the depth below SURF at which an evapotranspiration rate of zero is applied, was developed using land-use data and the South Florida Water Management Model Basic Land Use extinction depth information (South Florida Water Management District, 2005). To account for spatial variability in EXDP not captured by the land-use-based EXDP coverage, a set of coarse pilot point multiplier parameters were applied to the base EXDP coverage. To account for land-use changes, development, and water-table changes resulting from development, the base EVT Package EXDP was adjusted using decadal multipliers. The EXDP decadal multipliers were adjusted during model calibration to improve model fit (table 1-4). Extinction depth multipliers represent a conceptual parameter that increases with time, consistent with lower groundwater levels under developed conditions. EXDP values for the period from 2010 through 2012 ranged from 0.77 to $26.28 \mathrm{ft}$ (fig. $1-12$ ).

Net recharge to the groundwater system was not specified. Instead, net recharge in the model is dynamically calculated using the sum of specified rainfall rates and calculated groundwater evapotranspiration. 
Table 1-4. Calibrated extinction depth multipliers.

\begin{tabular}{cc}
\hline Period & Multiplier \\
\hline $1950-59$ & 5.30 \\
$1960-69$ & 4.48 \\
$1970-79$ & 5.44 \\
$1980-89$ & 6.64 \\
$1990-99$ & 7.62 \\
$2000-09$ & 7.96 \\
$2010-12$ & 7.70 \\
\hline
\end{tabular}

\section{Intracoastal Waterway and Tidal Finger Canals}

The MODFLOW General Head Boundary (GHB) Package was used to simulate the Intracoastal Waterway and associated tidal finger canals in the active model domain (fig. 1-11). The tidal GHBs were located in layer 1 and were specified to have Atlantic Ocean tidal stages (fig. 3), a conductance of $100 \mathrm{ft}^{2} / \mathrm{d}$, and seawater salinities. The locations of the Intracoastal Waterway and associated tidal finger canals were not changed during the simulation.

\section{Non-Tidal Surface-Water Canals}

Primary and secondary canals were simulated differently than tertiary canals, based on the availability of data needed to specify the head-dependent flux boundary conditions.

\section{Primary and Secondary Canals}

The MODFLOW River (RIV) Package was used to simulate interaction between the groundwater system and the primary and secondary canal system as canal head-dependent boundaries (fig. 1-11). Most canal reaches used in the model, as well as the spatial distribution and geometry of the reaches, were specified using data from MIKE SHE models developed for Broward County (Camp Dresser and McKee and DHI Water and Environment, 2002; DHI Water and Environment and Camp Dresser and McKee, 2005). The accuracy of these data is difficult to quantify, but they represent the best available surface-water system data for Broward County. The primary and secondary canals are operated by the SFWMD and local drainage districts, respectively, to control water levels in Broward County and control flooding during highintensity rainfall events.

Many of the primary and secondary canals were constructed after 1950 . As a result, primary and secondary canals were not active in the model prior to their construction date and are active after their construction date. Construction timeframes for the primary and secondary canals were determined using data from Renken and others (2005) or from aerial photos.
All of the RIV boundaries were specified to be in layer 1 . The stage for each RIV boundary representing a primary canal or an uncontrolled secondary canal was based on observed stage data from the USGS NWIS or SFWMD DBHYDRO databases. Upstream of the salinity control structures, headwater stages were applied between surface-water control structures. For example, S13 headwater stages were applied to the $\mathrm{C}-11$ canal between the S13A and S13 surface-water control structures (fig. 1-1). River stages in secondary canals separated from primary canals by a surface-water control structure were specified to be equal to surface-water control elevations defined in watershed management plans developed for drainage districts in Broward County. Primary canal stages were used in secondary canals because observed stages were not available for these canals. The river bottom for each RIV boundary was developed using cross-section data contained in the MIKE SHE models developed for Broward County (Camp Dresser and McKee and DHI Water and Environment, 2002; DHI Water and Environment and Camp Dresser and McKee, 2005). The riverbed conductance for 156 reaches grouped into unique canal segments within individual surface-water subbasins are based on the length and wetted perimeter of each canal in a cell and the vertical hydraulic conductivity of the bed; conductances were adjusted during model calibration. Calibrated riverbed conductance values ranged from $2.1 \times 10^{0}$ to $2.6 \times 10^{6} \mathrm{ft}^{2} / \mathrm{d}$ and had a median value of $4.8 \times 10^{4} \mathrm{ft}^{2} / \mathrm{d}\left(\mathrm{P}_{25}=2.2 \times 10^{4} \mathrm{ft}^{2} / \mathrm{d} ; \mathrm{P}_{75}=1.1 \times 10^{5} \mathrm{ft}^{2} / \mathrm{d}\right)$. All RIV boundaries upstream and downstream of salinity control structures were specified to have freshwater salinities and seawater salinities, respectively.

\section{Tertiary Canals}

Surface-water structures (for example, culverts) in the tertiary canal system in Broward County are used to maintain specific control elevations in surface-water subbasins. The tertiary system was not explicitly represented in the model because of a lack of observation data. The effect of the tertiary canal system on groundwater levels was conceptually simulated using the MODFLOW Drain (DRN) Package. Watershed management plans developed by the drainage districts in Broward County were used to define control elevations (fig. 1-13). Drainage elevations range from 1.5 to $13.3 \mathrm{ft}$ and generally increase from east to west. Drainage elevations are highest in the Pompano Beach area of the model (fig. 1-13) and correspond to the highest land-surface elevations in the active model domain (fig. 1-3). Prior to activation of canals in an area, drainage elevations were specified to be $0.25 \mathrm{ft}$ above land-surface elevation to represent water loss from the aquifer resulting from overland flow once an initial ponding depth is exceeded. Aerial photographs were used to determine the chronology of development in Broward County. DRN boundaries in undeveloped and developed areas were assigned conductance values of $6 \times 10^{7}$ and $2.5 \times 10^{4} \mathrm{ft}^{2} / \mathrm{d}$, respectively. 


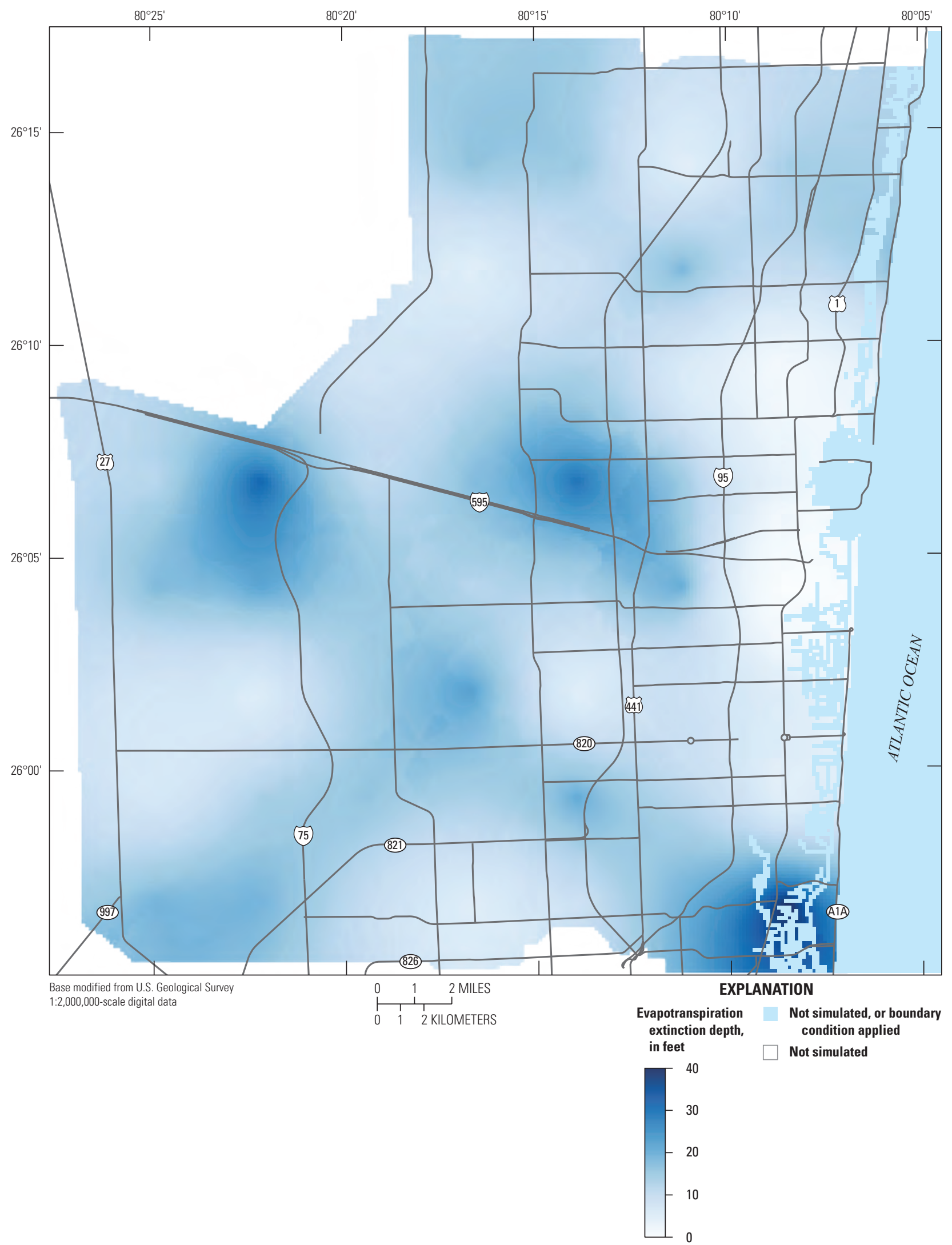

Figure 1-12. Calibrated extinction depth for the period from 2010 through 2012. 


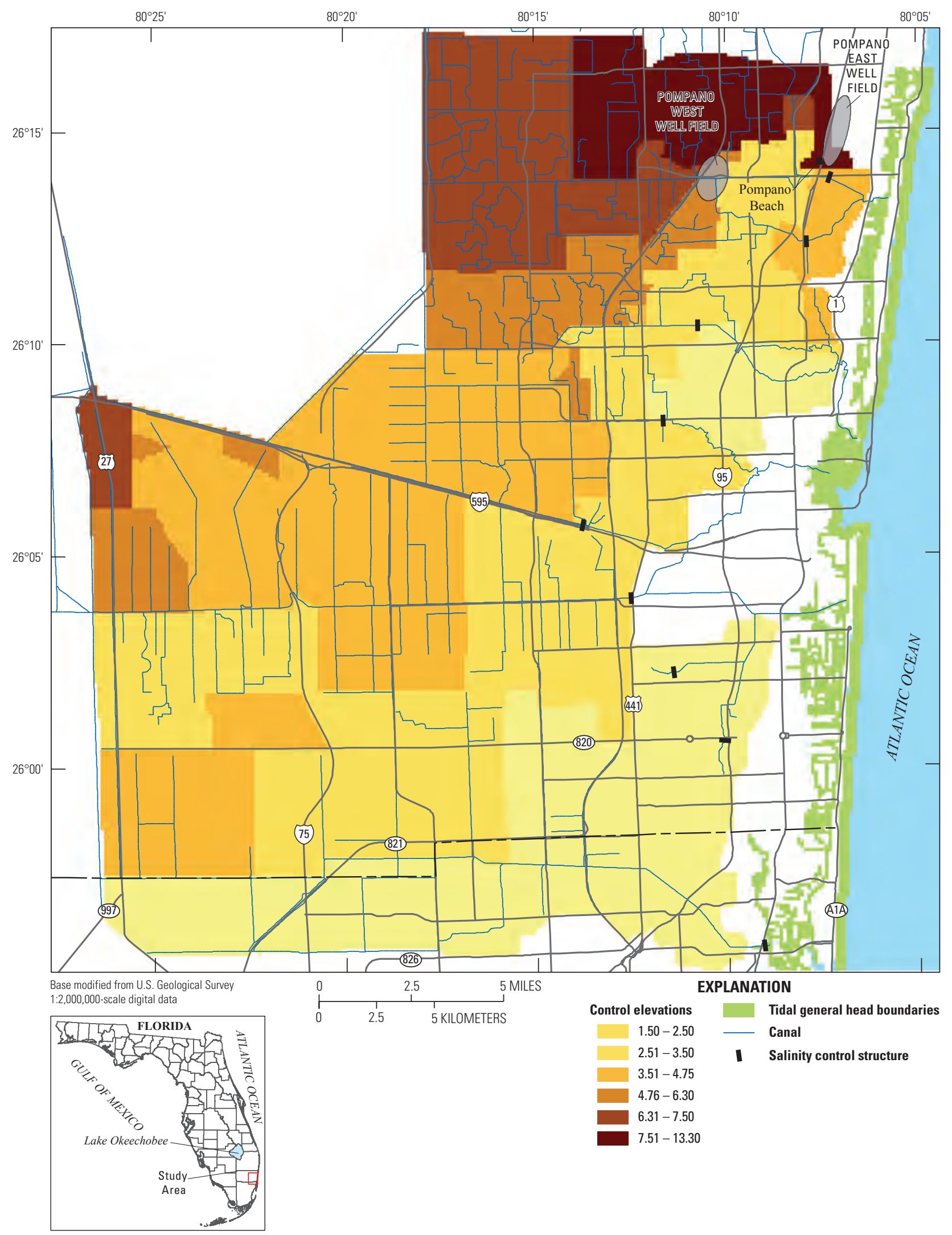

Figure 1-13. Drainage elevations used in developed areas of Broward County to represent the effect of tertiary canals on water-table elevations. 
Groundwater Flow Across the Northern and Southern Edge of the Model

GHB boundaries were used to represent the potential for groundwater flow across the northwestern and southwestern edges of the model. The northwestern and southwestern GHBs were located in each model layer, assigned a conductance equal to $100 \mathrm{ft}^{2} / \mathrm{d}$ times the layer thickness in a cell, and assigned freshwater salinities. The locations of the northern and southern GHBs (fig. 1-11) were not changed during the simulation. GHB heads along the northern edge of the model were linearly interpolated using observed groundwater data for wells G-2485, G-2475, G-2484, G-1306, G-616, G-2483, G-2156, G-2030, G-2031, G-1213, and G-2739 (fig. 1-11). GHB heads along the southern edge of the model were linearly interpolated using observed groundwater data for wells $\mathrm{G}-72$, G-3571, G-1637, G-970, and G-1636 (fig. 1-11).

\section{Water Conservation Areas 2A, 2B, and 3B}

Wetland areas within Water Conservation Areas 2A, 2B, and $3 \mathrm{~B}$ were simulated using GHB boundaries in all layers (fig. 1-11). Daily stage data from the Everglades Depth Estimation Network (EDEN) were used to define boundary stages in wetland areas. Daily EDEN stage data are interpolated to a $400-\mathrm{m} \times 400-\mathrm{m}$ grid covering all of the water conservation areas (Telis, 2006; Pearlstine and others, 2007).

Daily EDEN stage data were averaged to calculate monthly values and interpolated to the model grid using bilinear interpolation (Press and others, 1990) for the period that EDEN data are available (beginning January 1, 1991). The average monthly EDEN stage was used to define the GHB stage data for the period before EDEN data are available. The location of wetland-area GHBs were not changed during the simulation. Wetland-area GHB conductance values were specified based on a hydraulic conductivity of $100 \mathrm{ft} / \mathrm{d}$, the horizontal cell dimensions, and the layer thickness in a cell. Wetland areas were assigned freshwater salinities.

\section{Initial Conditions for Water Levels and Salinity}

The initial heads were specified to be $1 \mathrm{ft}$ below land surface, which is a reasonable assumption for the active model domain. The initial salinity distribution was generated by simulating a 200-year period and reusing the historic aquifer stresses from the 1950-52 period. This process yielded an initial salinity distribution that is close to steady state with the initial stresses in the model. The initial concentration distribution was adjusted as part of the calibration process using the utility software ELEV2CONC (Doherty, 2010) to translate the pilot-point-modified interface elevation distribution into initial concentration distributions for use in the model.

\section{Hydraulic Parameters}

The hydraulic properties of the Biscayne aquifer and underlying Pinecrest Sand and Ochopee Limestone control the effects of groundwater pumping on groundwater levels and movement of the freshwater-saltwater interface. For the model to successfully predict those effects, the values of the hydraulic properties were adjusted within reasonable limits during model calibration to improve the model simulations and fit to observed data (table 1-5).

\section{Hydraulic Conductivity}

Initial horizontal hydraulic conductivities for layers 1 through 10 were developed from data for 172 wells summarized in Fish (1988). Initial hydraulic conductivities for layers 11 and 12 were specified to be $500 \mathrm{ft} / \mathrm{d}$. Given the karstic nature of the Biscayne aquifer and the relatively large grid-cell sizes, the initial vertical hydraulic conductivity of each layer was assumed to be equal to the initial horizontal conductivity to represent the large potential for vertical movement of groundwater within the resolution of each model cell. The horizontal and vertical hydraulic conductivities of the UPR, PD1, PD2, and LWR units (fig. 6) were only allowed to vary from initial values if observation data used to constrain model calibration supported such variation. The range of horizontal and vertical hydraulic conductivity values were constrained to values between $1.0 \times 10^{-3}$ and $3.2 \times 10^{4} \mathrm{ft} / \mathrm{d}$, based on the approach used by Langevin and Zygnerski (2013).

The calibrated horizontal and vertical hydraulic conductivity of the UPR unit ranged from approximately $1.6 \times 10^{2}$ to $3.2 \times 10^{4} \mathrm{ft} / \mathrm{d}$ and $8.8 \times 10^{-1}$ to $3.2 \times 10^{1} \mathrm{ft} / \mathrm{d}$, respectively (fig. $1-14 A-B$ ). The calibrated hydraulic and vertical hydraulic conductivity of the PD1 unit ranged from approximately $1.7 \times 10^{2}$ to $3.2 \times 10^{4} \mathrm{ft} / \mathrm{d}$ and $1.6 \times 10^{0}$ to $2.6 \times 10^{1} \mathrm{ft} / \mathrm{d}$, respectively (fig. $1-15 A-B$ ). The calibrated horizontal and vertical hydraulic conductivity the PD2 unit ranged from approximately $2.1 \times 10^{2}$ to $2.3 \times 10^{4} \mathrm{ft} / \mathrm{d}$ and $2.6 \times 10^{0}$ to $1.6 \times 10^{1} \mathrm{ft} / \mathrm{d}$, respectively (fig. $1-16 A-B$ ). Calibrated Biscayne aquifer horizontal hydraulic conductivities are within the range of values (from $7.5 \times 10^{1}$ to $7.8 \times 10^{4} \mathrm{ft} / \mathrm{d}$ ) estimated for the aquifer from aquifer performance tests (Fish, 1988). The calibrated horizontal and vertical hydraulic conductivity of the LWR unit ranged from approximately $1.9 \times 10^{2}$ to $2.6 \times 10^{4} \mathrm{ft} / \mathrm{d}$ and from $2.8 \times 10^{\circ}$ to $9.1 \times 10^{\circ} \mathrm{ft} / \mathrm{d}$, respectively (fig. $1-17 A-B$ ). Calibrated LWR unit hydraulic conductivities are comparable to the range of values (from $1.5 \times 10^{2}$ to $1.2 \times 10^{4} \mathrm{ft} / \mathrm{d}$ ) estimated for the gray limestone aquifer from aquifer performance tests (Reese and Cunningham, 2000). 


\section{Specific Yield, Specific Storage, and Porosity}

The specific yield, specific storage, and porosity of the model layers were estimated during the calibration process. Model layer 1 was defined to be convertible, and specific storage and specific yield values were specified for each model cell in this layer. The specific yield of the UPR unit was estimated and was applied in layer 1 . The specific storage was estimated for the UPR, PRD, and LWR units, and porosity was estimated for the UPR, PD1, PD2, and LWR units. Data were not available to constrain specific yield, specific storage, and porosity at individual points. Specific storage was constrained to values between $4.2 \times 10^{-7}$ and $1.0 \times 10^{-4} \mathrm{ft}^{-1}$, and specific yield and porosity were constrained to values between 0.01 and 0.4 .

Calibrated specific yield values for the UPR unit ranged from 0.03 to 0.4 (fig. 1-18). Calibrated specific storage values for the UPR, PRD, and LWR units ranged from $6.4 \times 10^{-6}$ to $1.3 \times 10^{-5} \mathrm{ft}^{-1}$ (fig. $1-19 A-C$ ). Calibrated porosity values for the UPR, PD1, PD2, and LWR units ranged from 0.01 to 0.4 (fig. 1-20A-C, D). Although specific yield, specific storage, and porosity data for the Biscayne aquifer are sparse, calibrated values were comparable to estimated values for the Biscayne aquifer in Broward County (Fish, 1988), the Biscayne aquifer in Miami-Dade County (Cunningham and others, 2006; Renken and others, 2008), and the gray limestone aquifer in Broward County (Reese and Cunningham, 2000).

\section{Model Fit}

The model was calibrated by adjusting selected input parameters to reduce the differences between the observed data and simulation results. Differences between the observed data and simulation results for the period from January 1970 through May 2012 were evaluated using a weighted L-2 norm objective function. The automated parameter estimation software (PEST) (Doherty, 2010) was used to reduce the weighted L-2 norm objective function to an acceptable value. The automated parameter estimation process was refined a total of eight times to improve observation processing, the number and type of parameters estimated, and the observation weighting strategy. The eighth and final PEST run was manually terminated after the ninth parameter estimation iteration when the reduction in the weighted $\mathrm{L}-2$ norm objective function (eq. A2) between successive iterations was less than 1 percent. A weighted L-2 norm of 323.9 (11 percent of the initial weighted L-2 norm) was obtained during the final iteration of parameter estimation process.
Although the weighted L-2 norm was used to terminate the final automated parameter estimation process, final model fit is presented in terms of the global mean error (ME) and root mean squared error (RMSE) for water levels and chloride concentrations. Chloride concentrations were calculated by multiplying fractional seawater concentrations by the seawater chloride concentration $(19,000 \mathrm{mg} / \mathrm{L})$.

The ME is the average of the differences between the simulated and observed values and is calculated as

$$
\mathrm{ME}=\frac{\sum_{i=1}^{n}\left(s_{i}-o_{i}\right)}{n}
$$

The RMSE is equivalent to the uncorrected sample standard deviation and is the square root of the average of the squared differences between simulated and observed values (Anderson and Woessner, 1992):

$$
\operatorname{RMSE}=\left[\frac{\sum_{i=1}^{n}\left(s_{i}-o_{i}\right)^{2}}{n}\right]^{1 / 2}
$$

\section{Chloride Concentrations}

Error statistics were calculated for 1,152 pairs of simulated and observed groundwater salinity values during the calibration period. Simulated and observed groundwater salinities at the 11 groundwater monitoring sites are shown on figure 1-21. During the calibration period, the global overall model ME and RMSE were 244.84 and $918.53 \mathrm{mg} / \mathrm{L}$, respectively. The small positive value for the overall $\mathrm{ME}$ indicates that the model is simulating salinities that are higher, on average, than observed values. The poorest fit to observed chloride concentrations was in G-2352, G-2899, and G-2900 (fig. 1-21) and is probably a consequence of poor initial conditions in these areas and (or) the inability of the model to simultaneously reproduce all observations, which indicates unknown complexities in the real system are not accounted for in the model.

Observed flow-weighted chloride concentrations at the Broward County 1A, 3A, and 3B; Dixie, Executive Airport and Prospect; Dania; Hollywood; and Hallandale well fields were zero during the calibration period. Simulated flowweighted well-field chloride concentrations were also zero during the calibration period. 
Table 1-5. Values and ranges of values of calibrated hydraulic properties, and hydraulic properties estimated from field data or laboratory samples.

[Units: $\mathrm{ft} / \mathrm{d}$, foot per day; $\mathrm{ft}^{2} / \mathrm{d}$, foot squared per day; ft, foot. Fm, formation; N/A, not applicable]

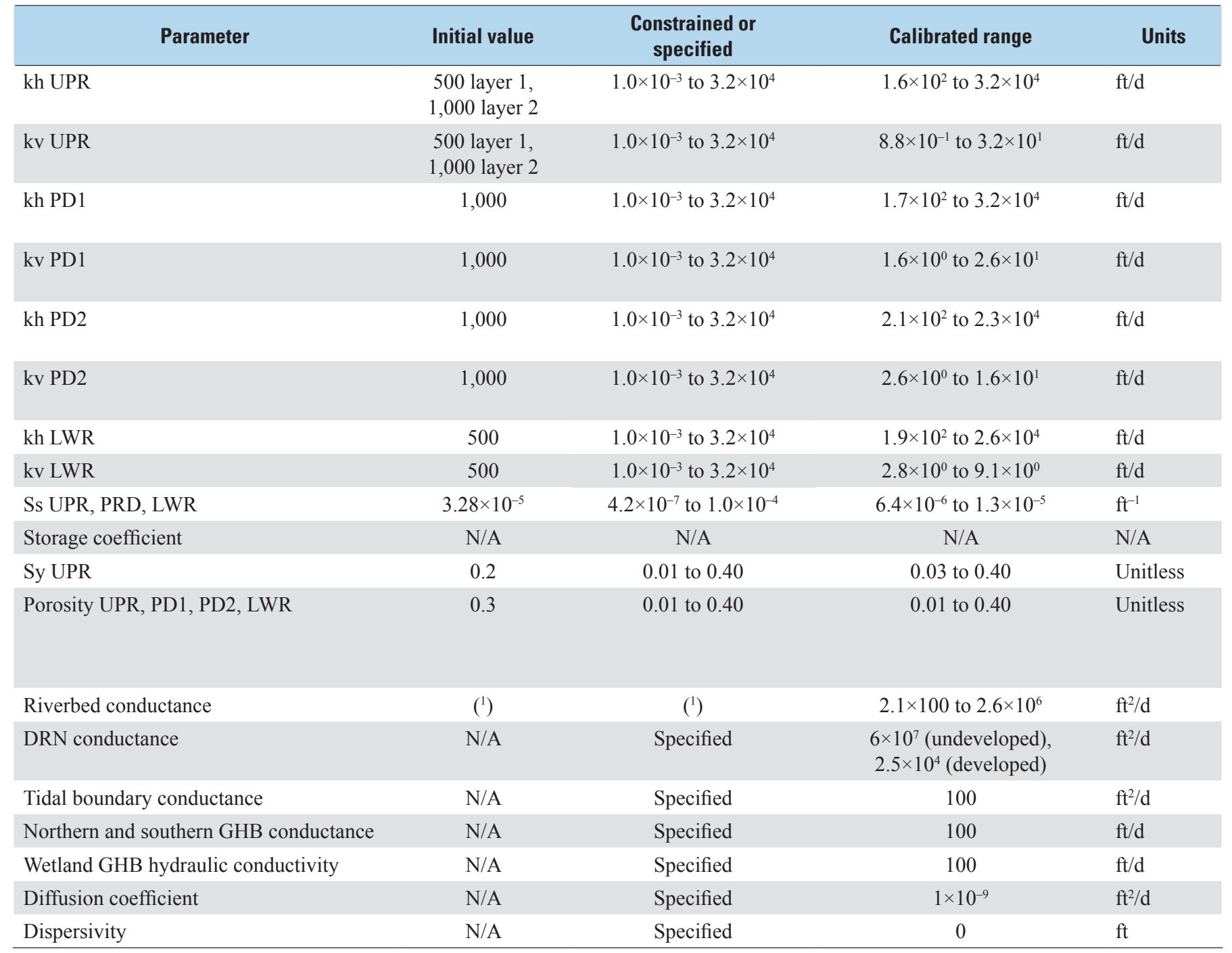

${ }^{1}$ Riverbed conductance is calculated as the product of vertical hydraulic conductivity, kv, and the area of the cell, divided by the thickness of the cell. To calibrate riverbed conductance, kv was adjusted using the initial values and constraints used to calibrate kv UPR. 
Table 1-5. Values and ranges of values of calibrated hydraulic properties, and hydraulic properties estimated from field data or laboratory samples.-Continued

[Units: ft/d, foot per day; $\mathrm{ft}^{2} / \mathrm{d}$, foot squared per day; ft, foot. Fm, formation; N/A, not applicable]

\begin{tabular}{|c|c|c|c|}
\hline $\begin{array}{l}\text { Estimated from } \\
\text { field or lab tests }\end{array}$ & Units & Reference & Notes \\
\hline $7.5 \times 10^{1}$ to $7.8 \times 10^{4}$ & $\mathrm{ft} / \mathrm{d}$ & Fish (1988) & $\begin{array}{l}\text { Average hydraulic conductivity, varying open intervals of } \\
\text { Ft. Thompson Fm., Tamiami Fm., Anastasia Fm. }\end{array}$ \\
\hline $7.5 \times 10^{1}$ to $7.8 \times 10^{4}$ & $\mathrm{ft} / \mathrm{d}$ & Fish (1988) & $\begin{array}{l}\text { Average hydraulic conductivity, varying open intervals of } \\
\text { Ft. Thompson Fm., Tamiami Fm., Anastasia Fm. }\end{array}$ \\
\hline $7.5 \times 10^{1}$ to $7.8 \times 10^{4}$ & $\mathrm{ft} / \mathrm{d}$ & Fish (1988) & $\begin{array}{l}\text { Average hydraulic conductivity, varying open intervals of } \\
\text { Ft. Thompson Fm., Tamiami Fm., Anastasia Fm. }\end{array}$ \\
\hline $7.5 \times 10^{1}$ to $7.8 \times 10^{4}$ & $\mathrm{ft} / \mathrm{d}$ & Fish (1988) & $\begin{array}{l}\text { Average hydraulic conductivity, varying open intervals of } \\
\text { Ft. Thompson Fm., Tamiami Fm., Anastasia Fm. }\end{array}$ \\
\hline $7.5 \times 10^{1}$ to $7.8 \times 10^{4}$ & $\mathrm{ft} / \mathrm{d}$ & Fish (1988) & $\begin{array}{l}\text { Average hydraulic conductivity, varying open intervals of } \\
\text { Ft. Thompson Fm., Tamiami Fm., Anastasia Fm. }\end{array}$ \\
\hline $7.5 \times 10^{1}$ to $7.8 \times 10^{4}$ & $\mathrm{ft} / \mathrm{d}$ & Fish (1988) & $\begin{array}{l}\text { Average hydraulic conductivity, varying open intervals of } \\
\text { Ft. Thompson Fm., Tamiami Fm., Anastasia Fm. }\end{array}$ \\
\hline $8 \times 10^{-7}$ & $\mathrm{ft}^{-1}$ & Fish (1988) & Specific storage, one value for Tamiami Fm. \\
\hline $2 \times 10^{-4}$ to $4 \times 10^{-3}$ & Unitless & Reese and Cunningham (2000) & Storage coefficient, 1 or 2 orders of magnitude larger than specific storage \\
\hline 0.004 to 0.30 & Unitless & Fish (1988) & Test data from other sources \\
\hline 0.37 to 0.40 & Unitless & Fish (1988) & Lab estimates from Tamiami and Hawthorn Fm. Core samples \\
\hline 0.18 to 0.33 & Unitless & Cunningham and others (2006) & Median helium porosity from core samples \\
\hline 0.04 to 0.41 & Unitless & Renken and others (2008) & Estimated from tracer tests in north central Miami-Dade County \\
\hline $\mathrm{N} / \mathrm{A}$ & $\mathrm{N} / \mathrm{A}$ & $\mathrm{N} / \mathrm{A}$ & No independently estimated or measured data found \\
\hline N/A & N/A & N/A & No independently estimated or measured data found \\
\hline
\end{tabular}




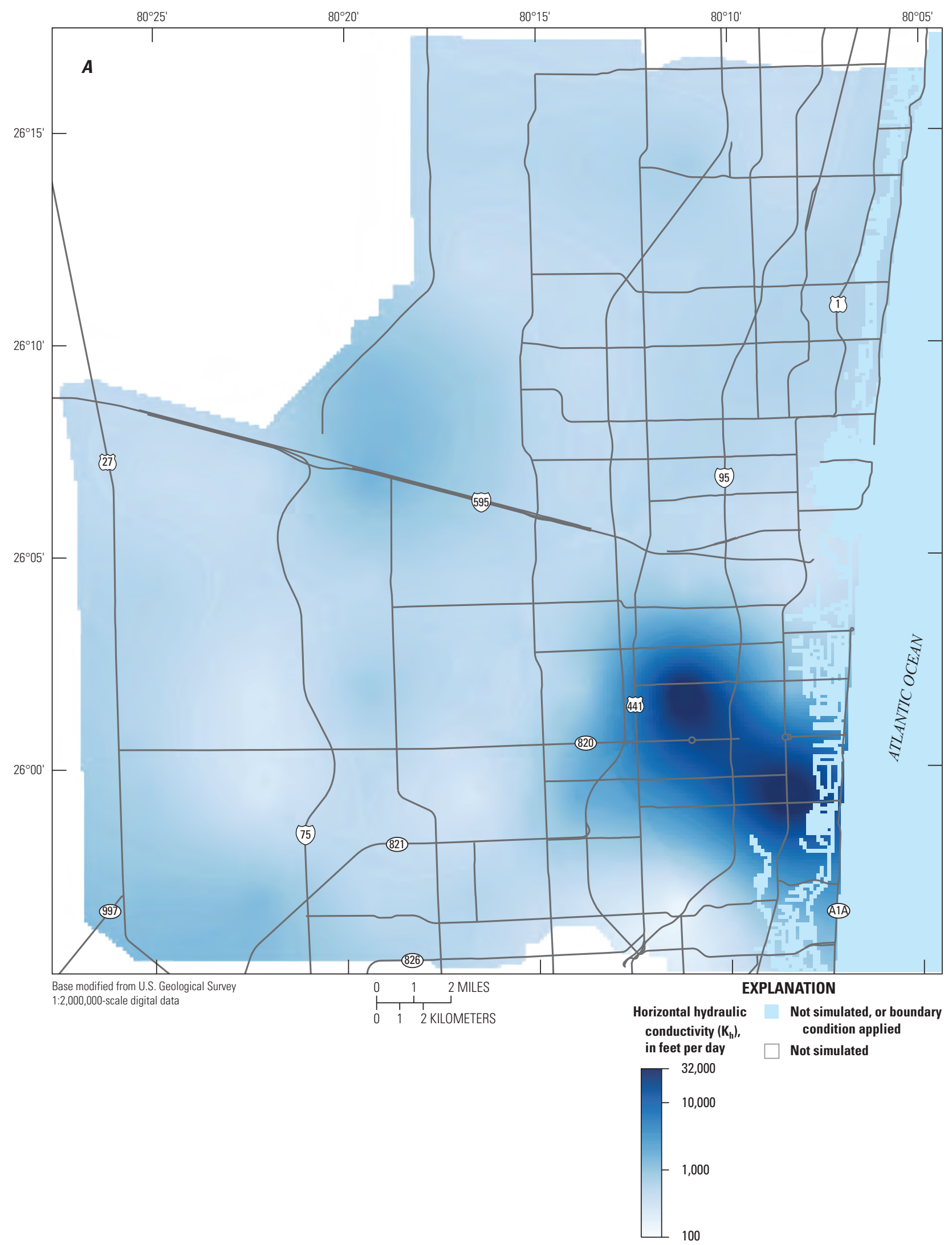

Figure 1-14. Calibrated $A$, horizontal and $B$, vertical hydraulic conductivity of the UPR unit. 


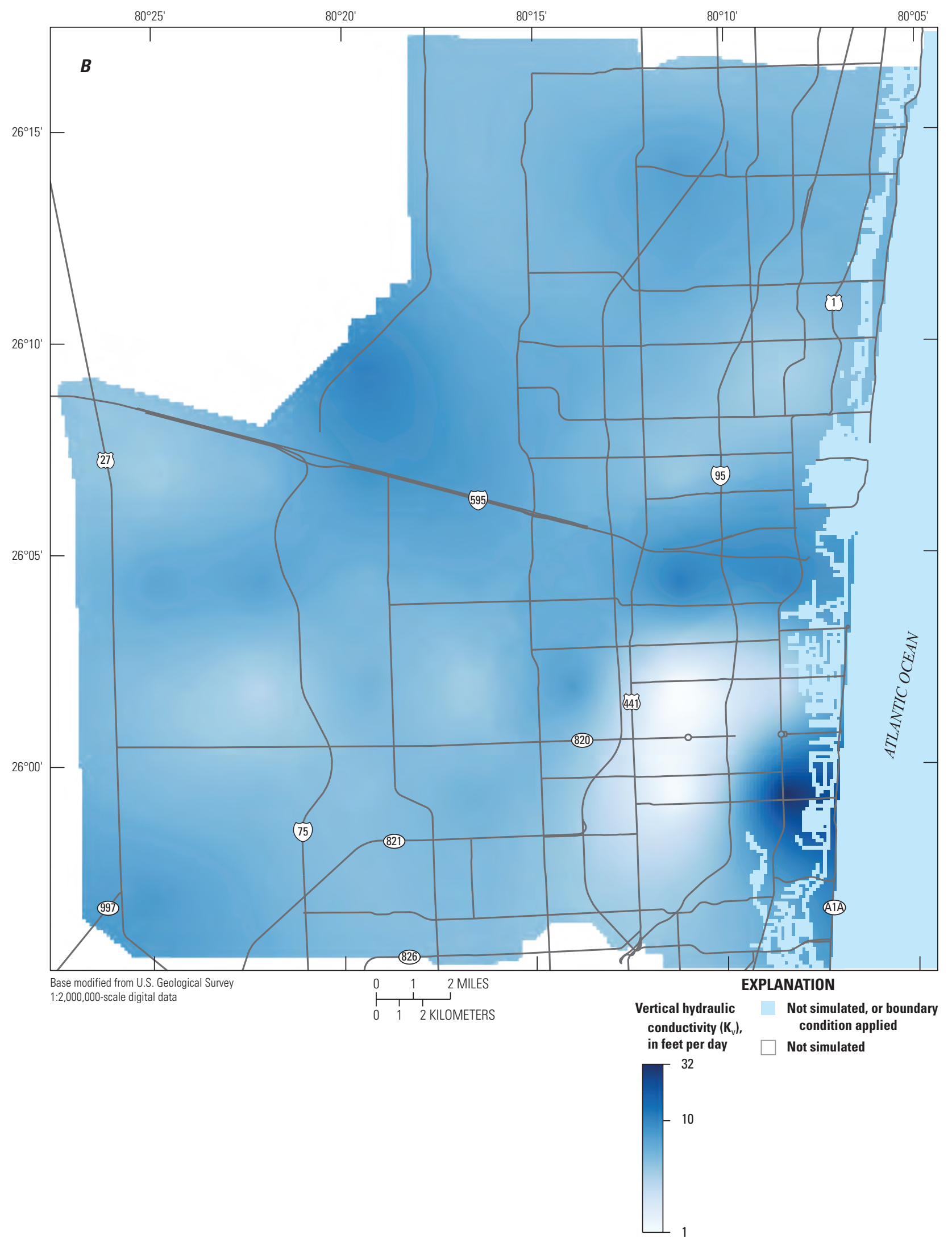

Figure 1-14. Calibrated $A$, horizontal and $B$, vertical hydraulic conductivity of the UPR unit.-Continued 


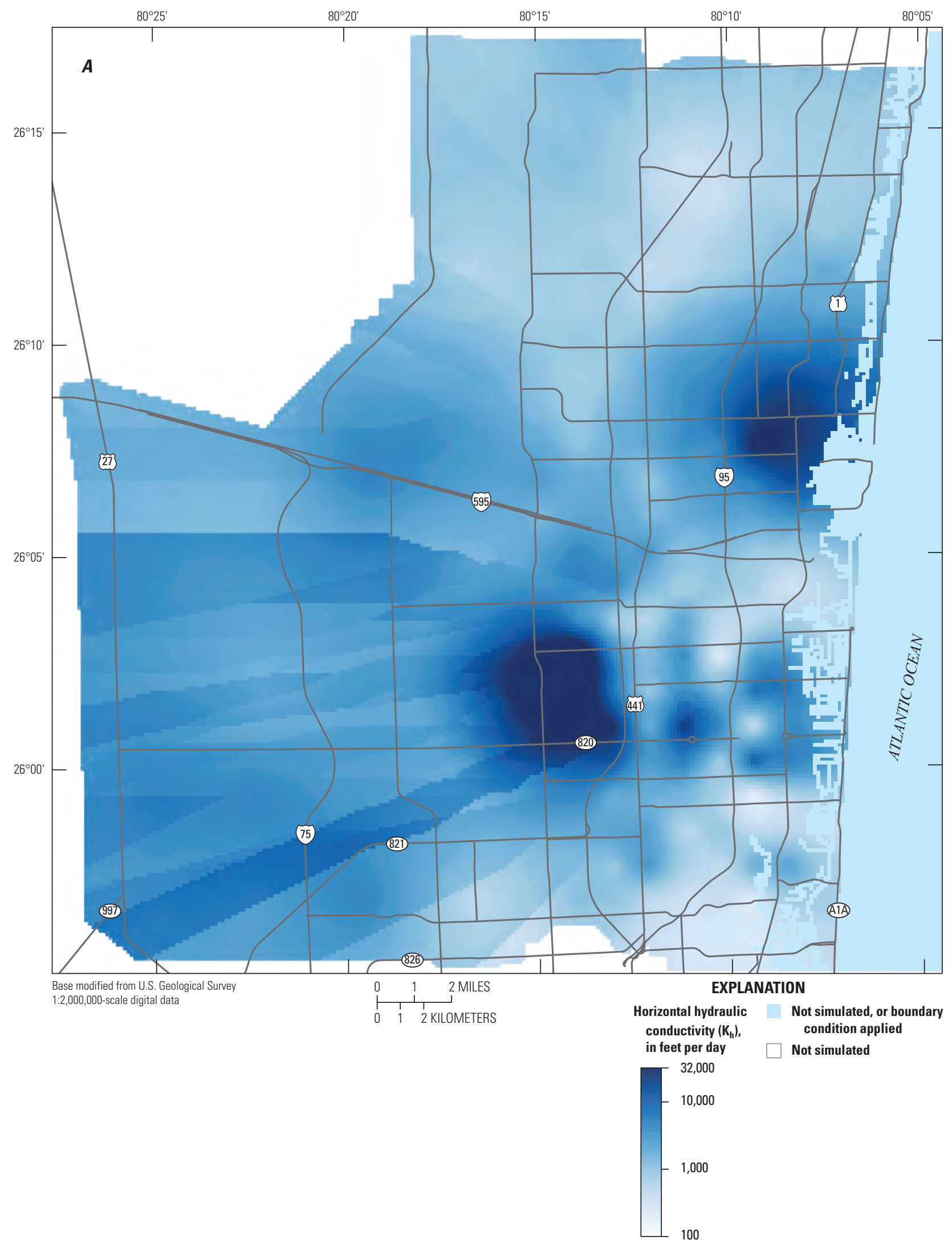

Figure 1-15. Calibrated $A$, horizontal and $B$, vertical hydraulic conductivity of the PD1 unit. 


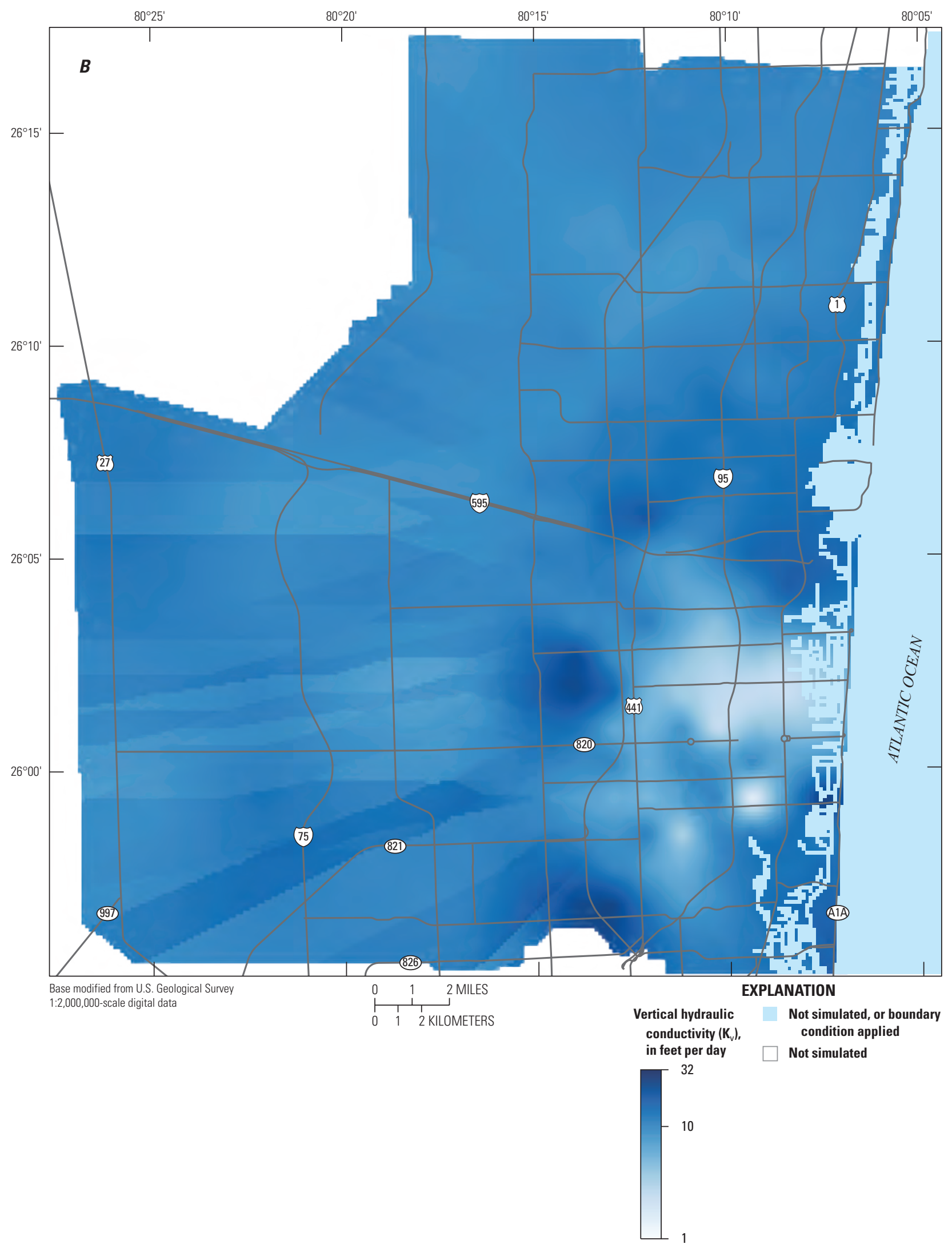

Figure 1-15. Calibrated $A$, horizontal and $B$, vertical hydraulic conductivity of the PD1 unit.-Continued 


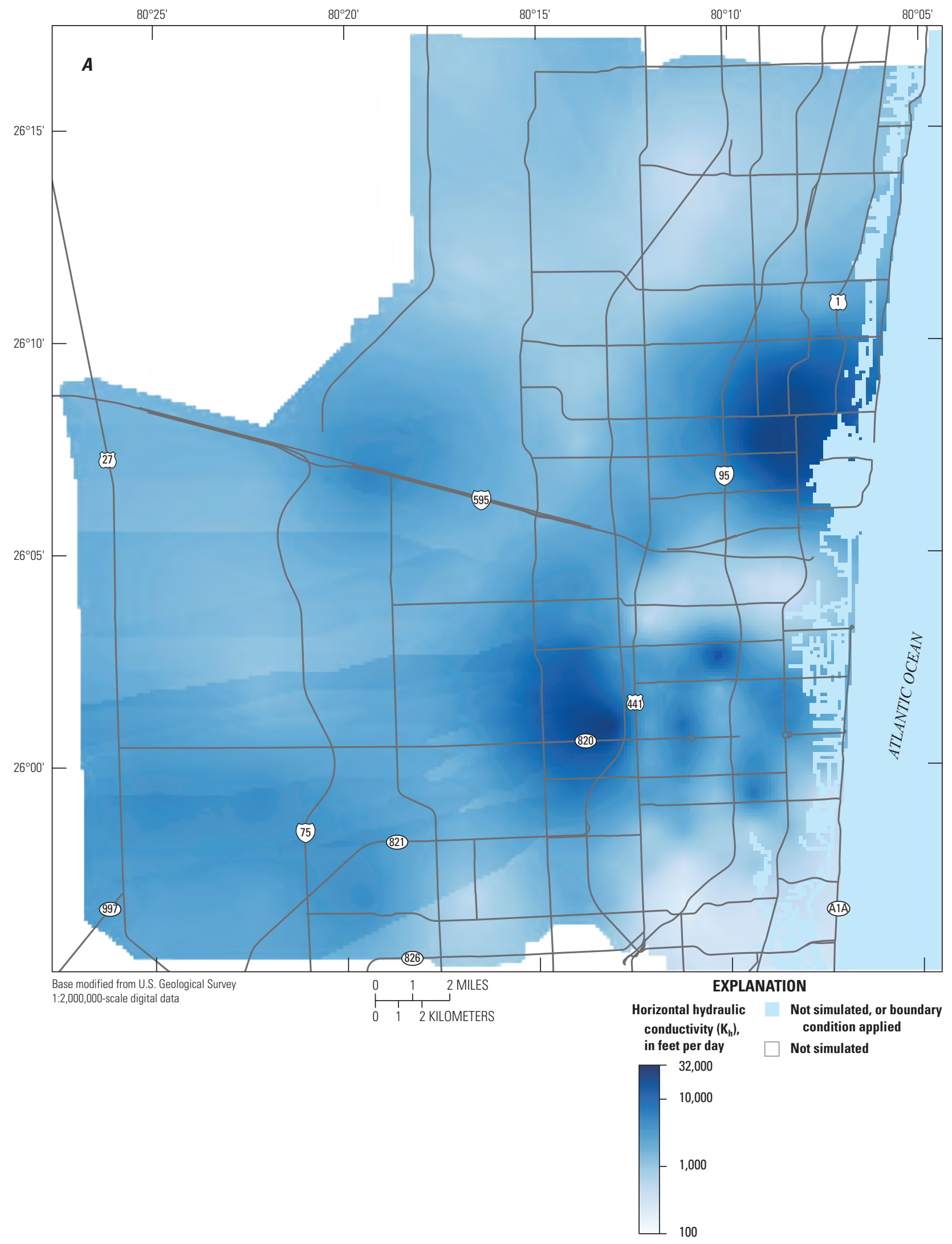

Figure 1-16. Calibrated $A$, horizontal and $B$, vertical hydraulic conductivity of the PD2 unit. 


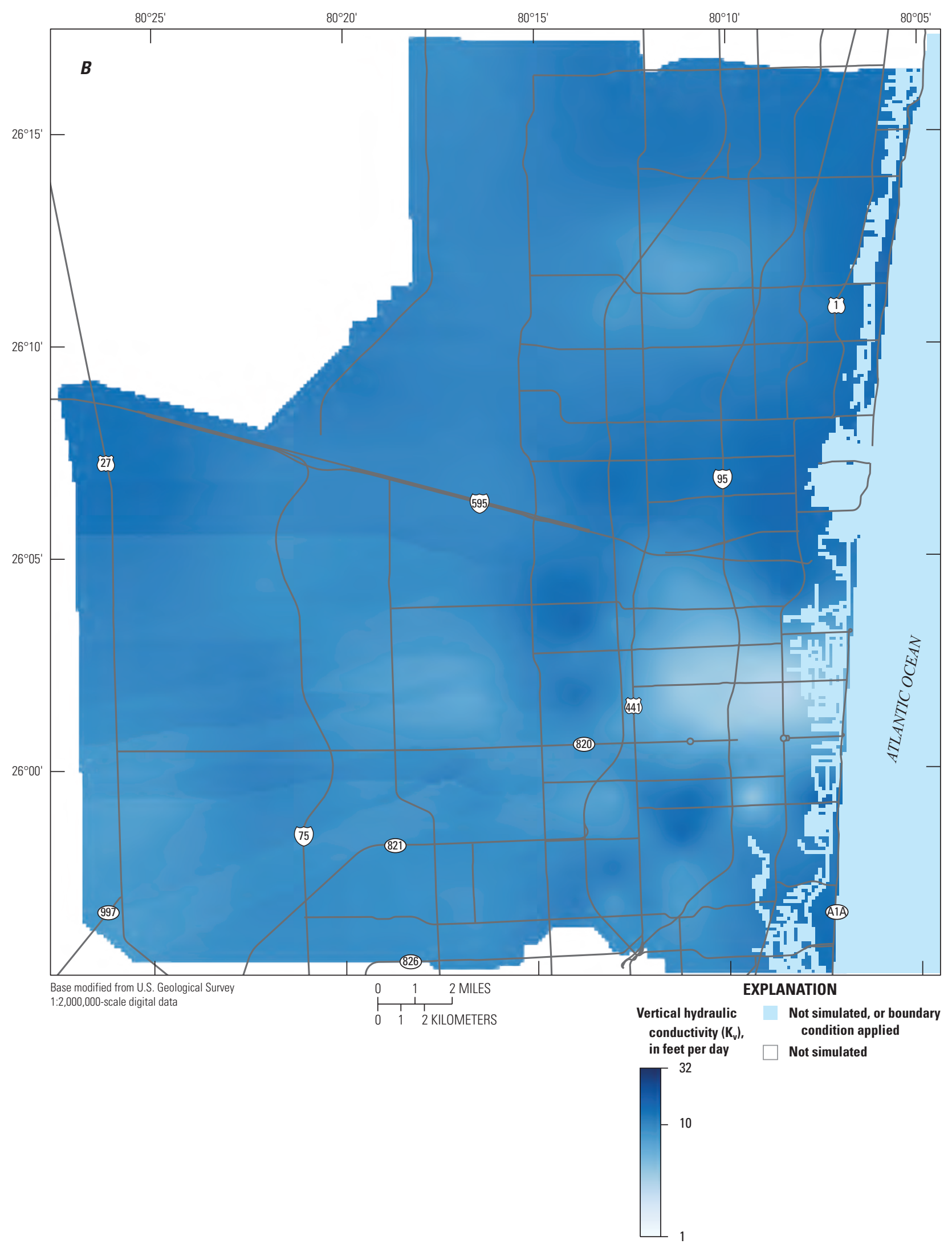

Figure 1-16. Calibrated $A$, horizontal and $B$, vertical hydraulic conductivity of the PD2 unit.-Continued 


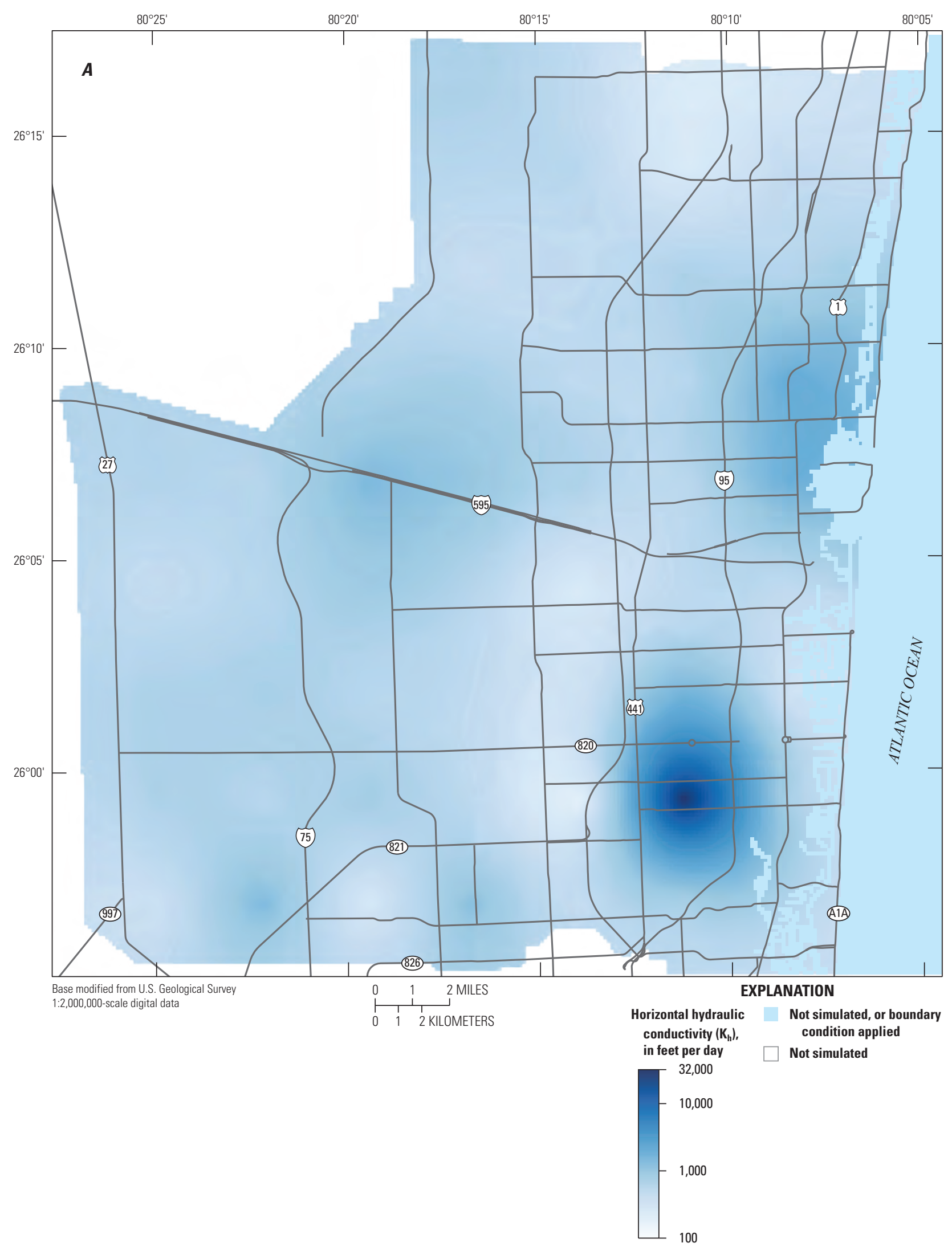

Figure 1-17. Calibrated $A$, horizontal and $B$, vertical hydraulic conductivity of the LWR unit. 


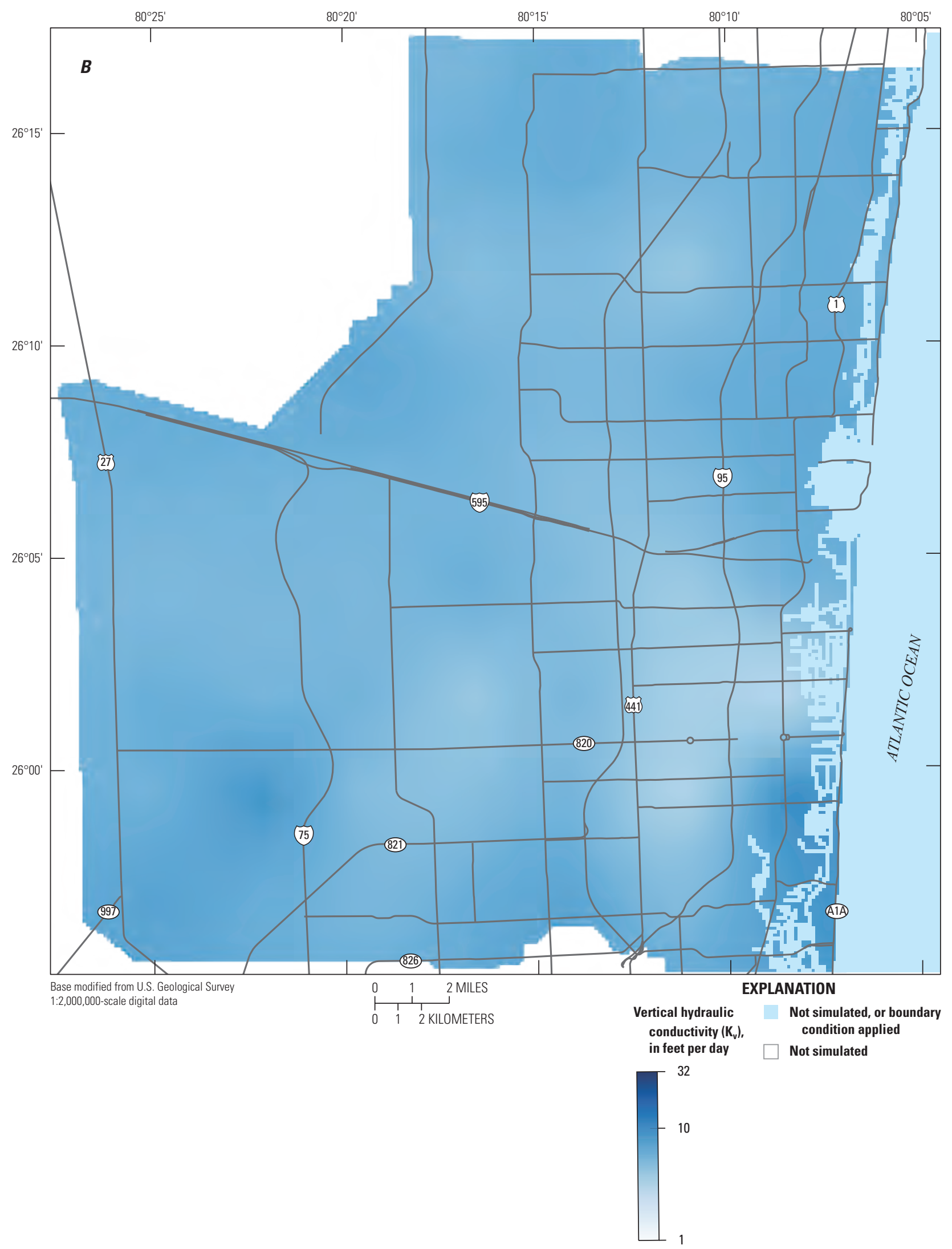

Figure 1-17. Calibrated $A$, horizontal and $B$, vertical hydraulic conductivity of the LWR unit.-Continued 


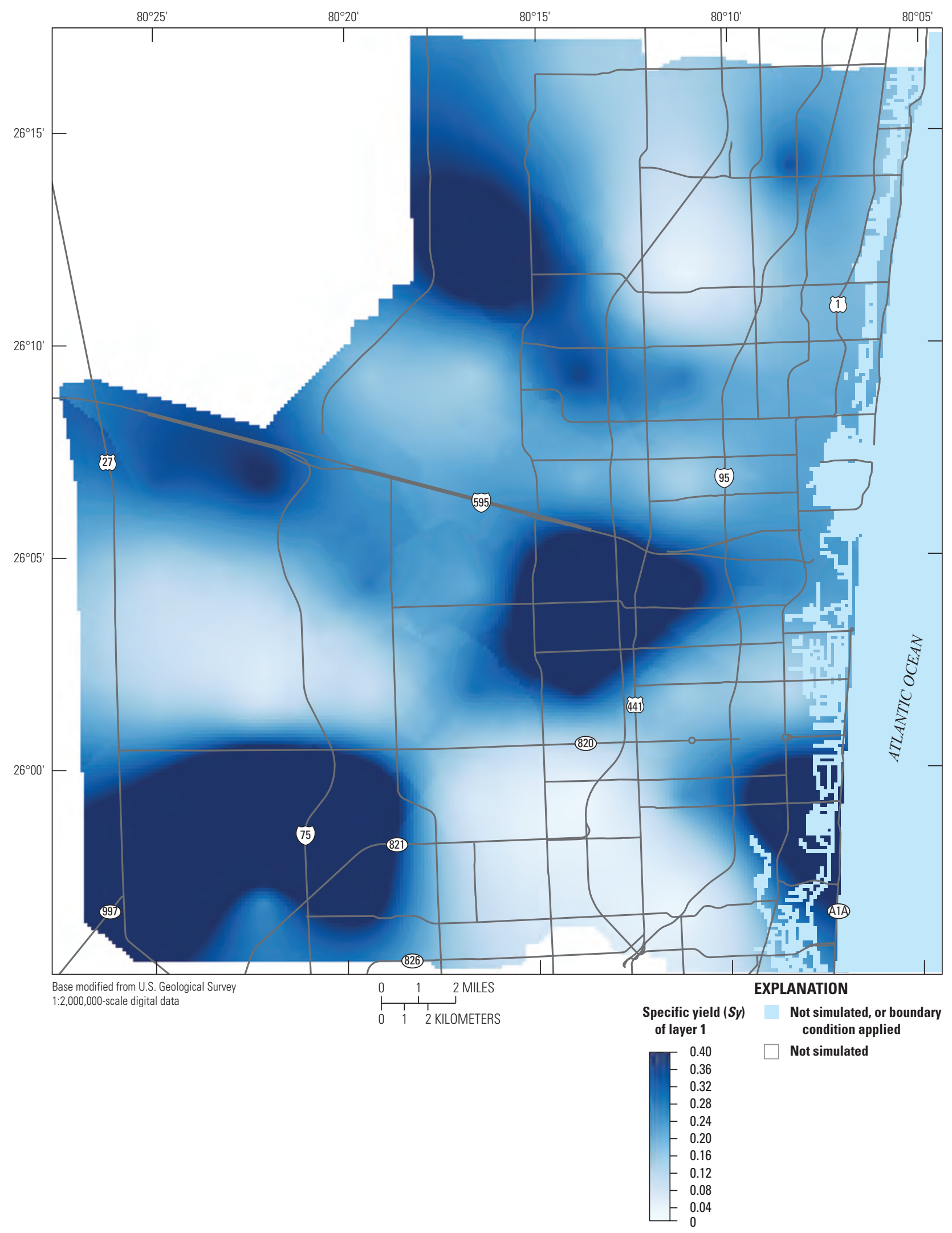

Figure 1-18. Calibrated specific yield for the UPR unit. 


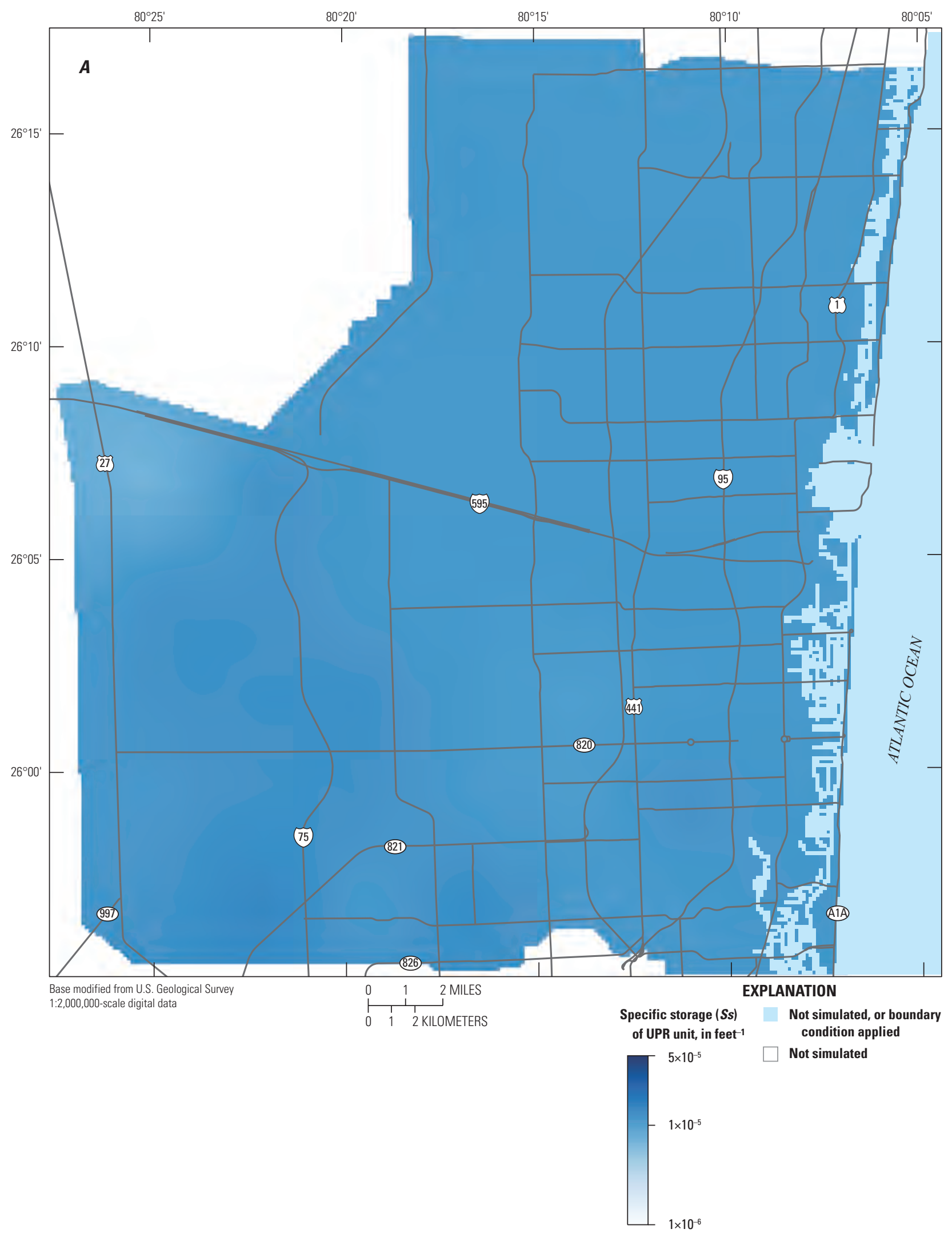

Figure 1-19. Calibrated specific storage values for the $A$, UPR, $B$, PRD, and $C$, LWR units. 


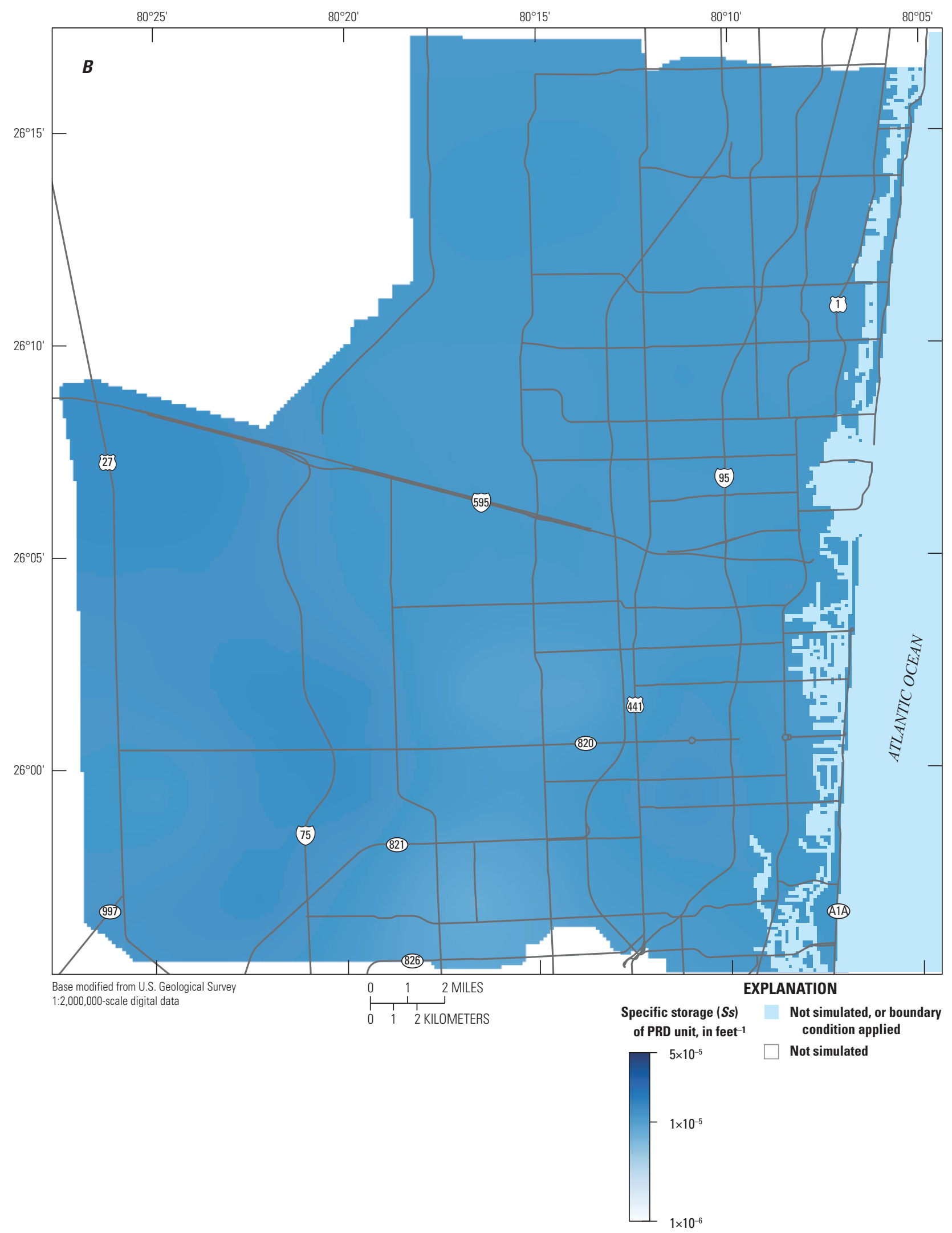

Figure 1-19. Calibrated specific storage values for the $A$, UPR, $B$, PRD, and $C$, LWR units.-Continued 


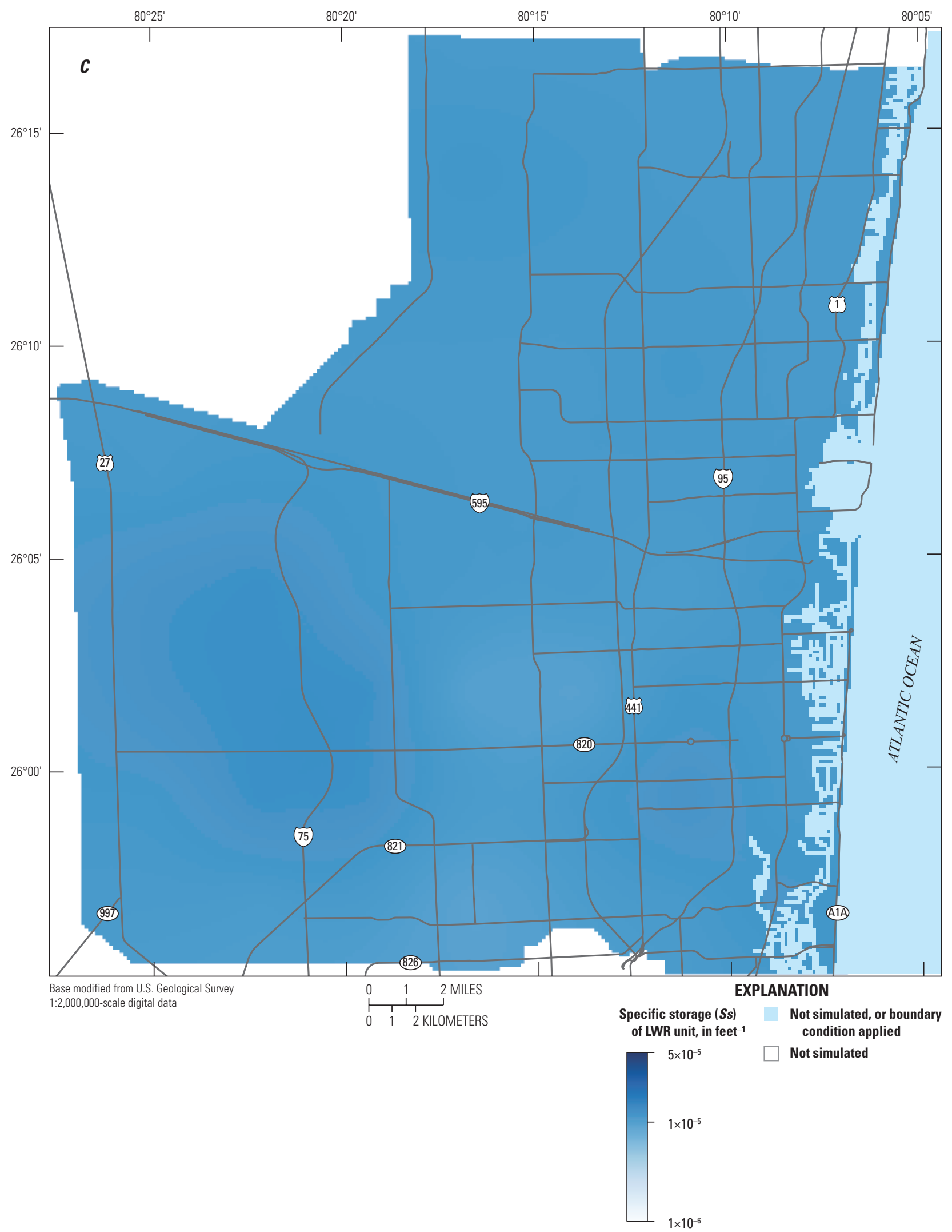

Figure 1-19. Calibrated specific storage values for the $A$, UPR, $B$, PRD, and $C$, LWR units.-Continued 


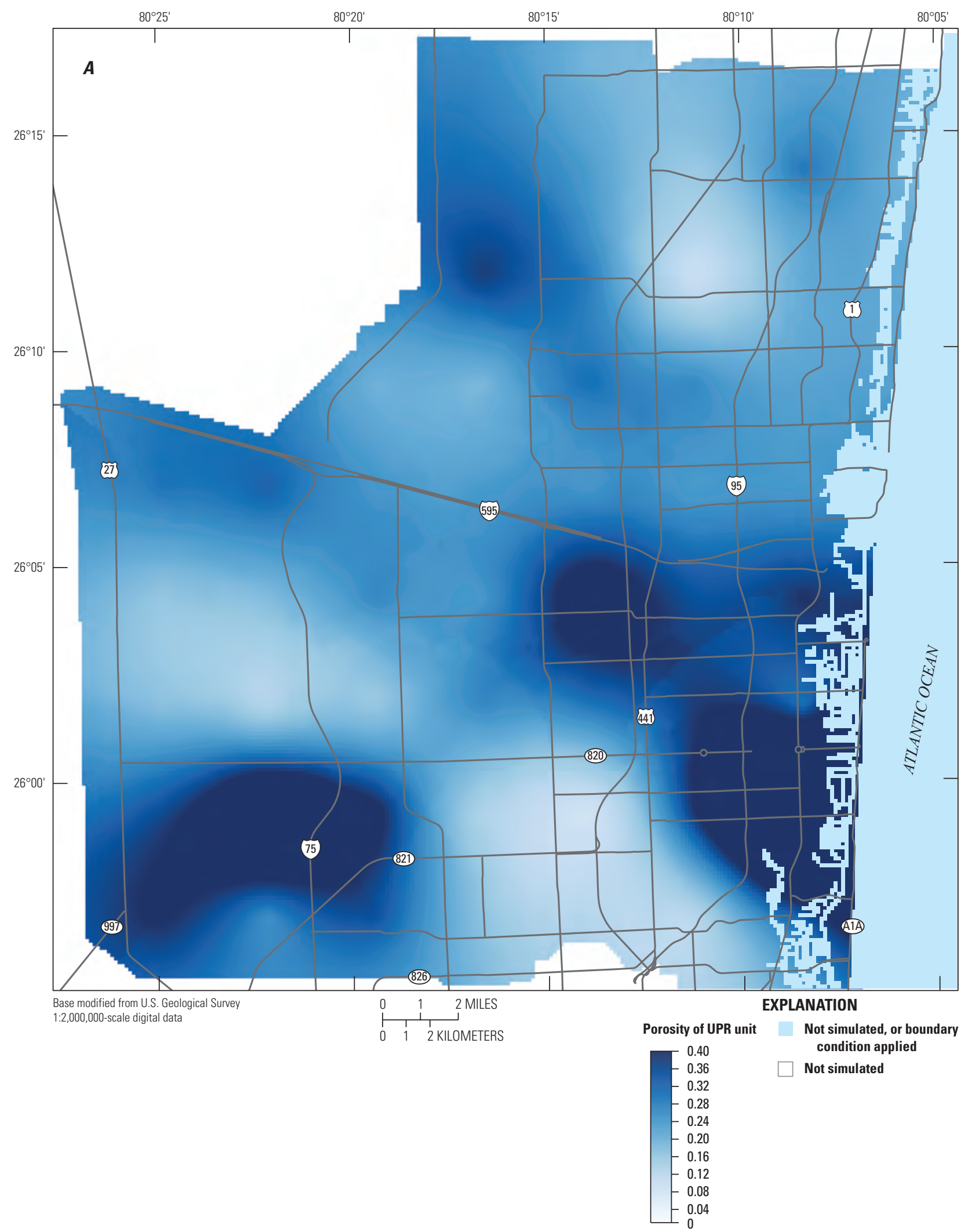

Figure 1-20. Calibrated porosity values for the $A$, UPR, $B$, PD1, $C$, PD2, and $D$, LWR units. 


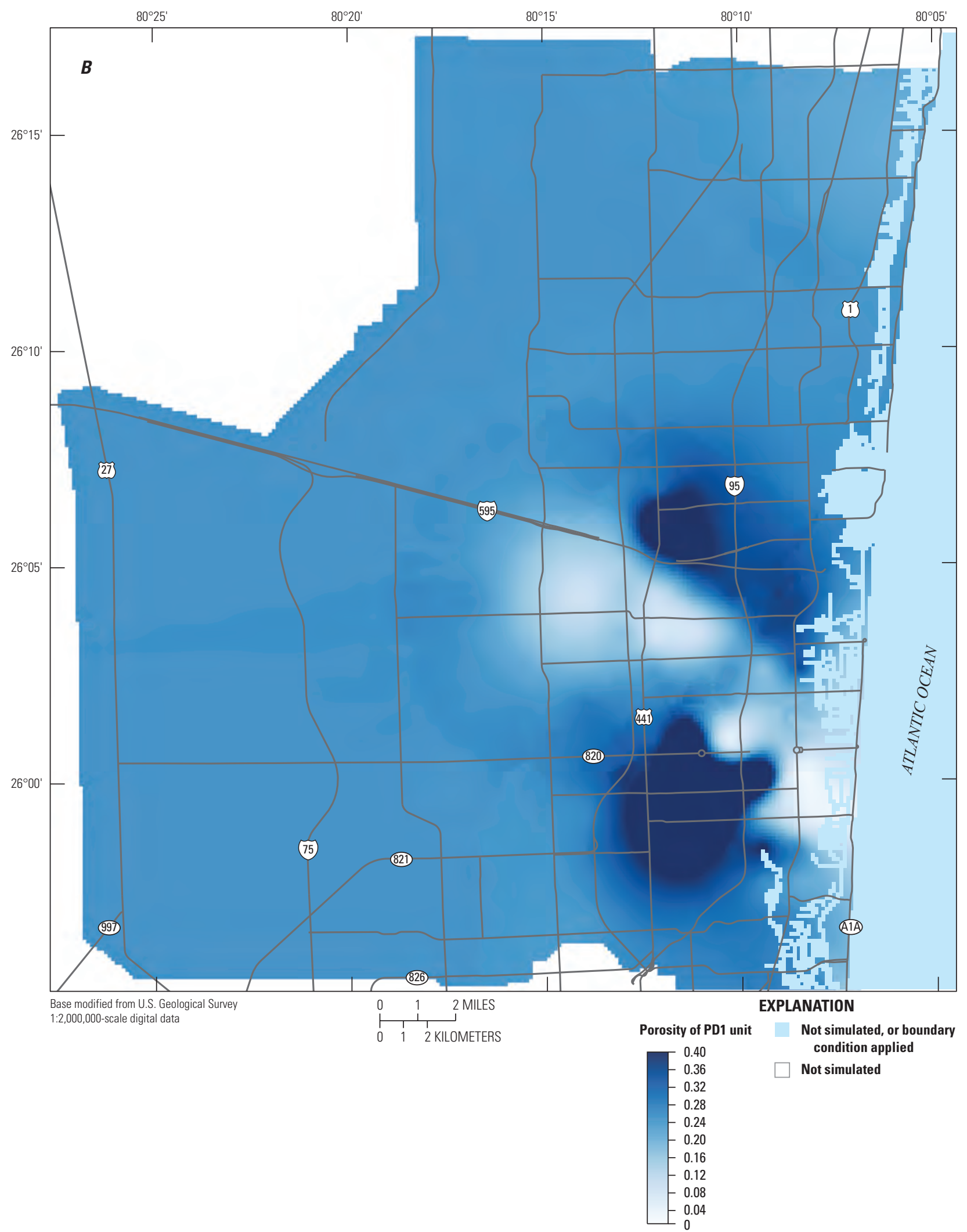

Figure 1-20. Calibrated porosity values for the $A$, UPR, B, PD1, C, PD2, and $D$, LWR units.-Continued 


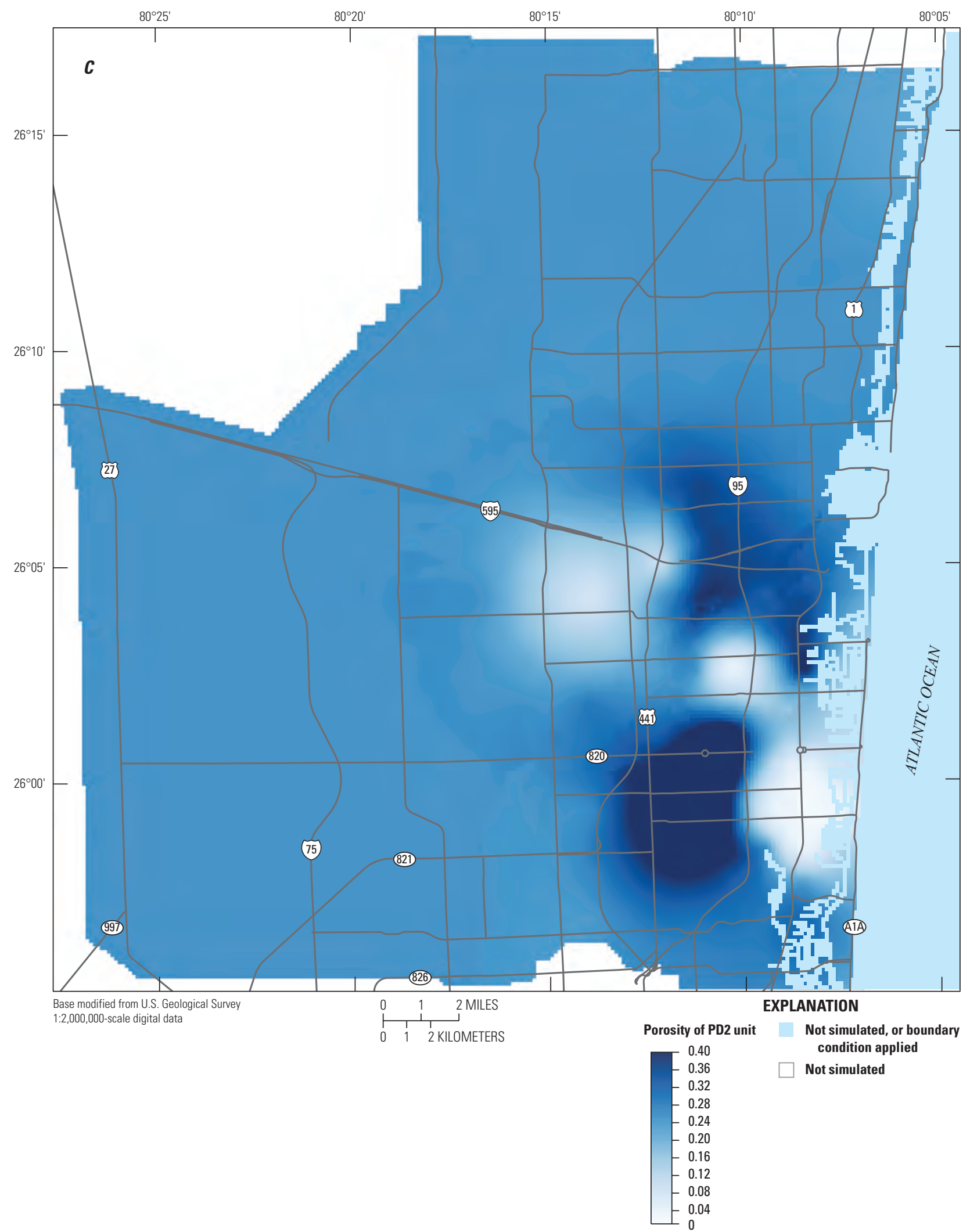

Figure 1-20. Calibrated porosity values for the $A, \mathrm{UPR}, B, \mathrm{PD} 1, C, \mathrm{PD} 2$, and $D$, LWR units. - Continued 


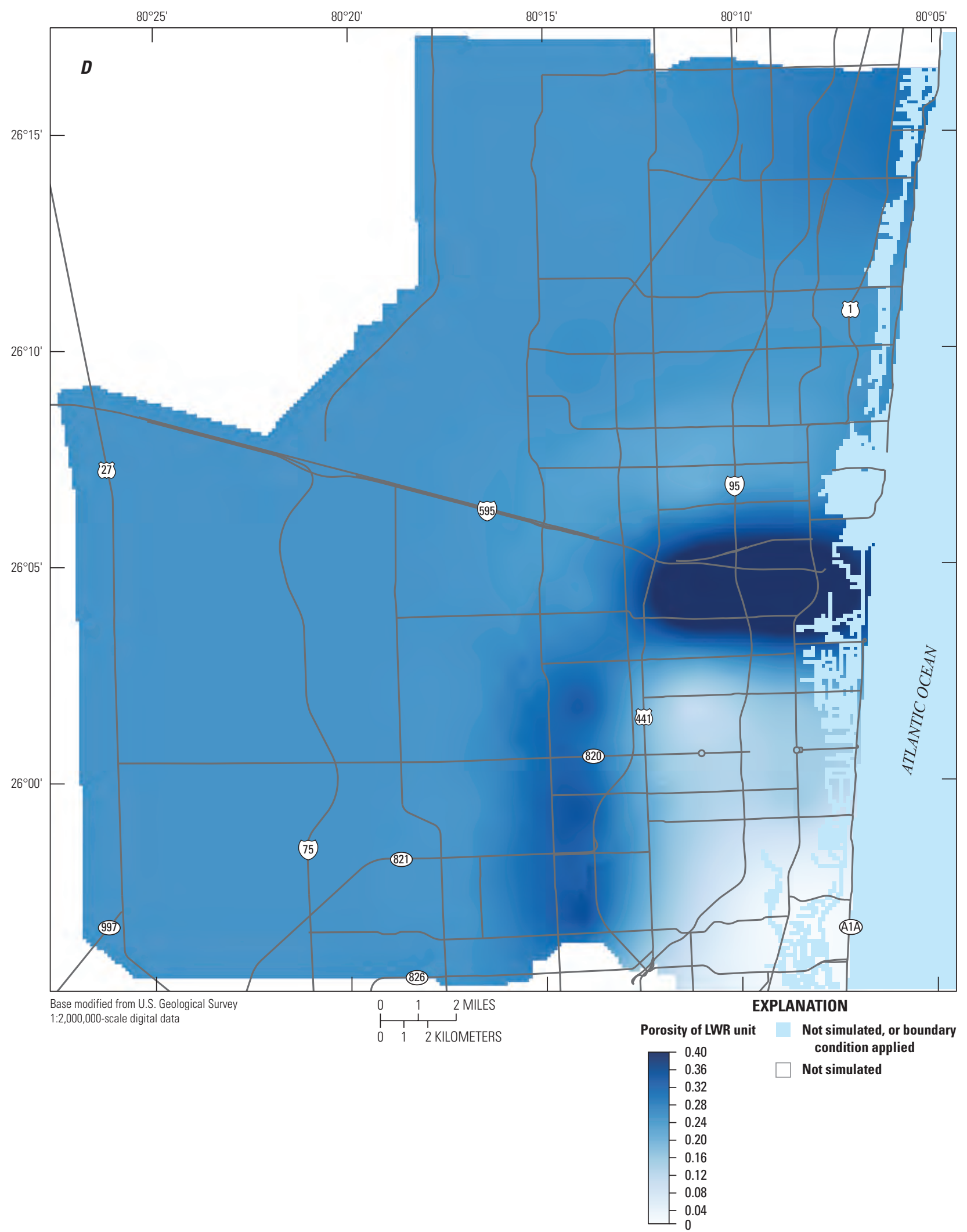

Figure 1-20. Calibrated porosity values for the $A$, UPR, B, PD1, C, PD2, and $D$, LWR units.-Continued 


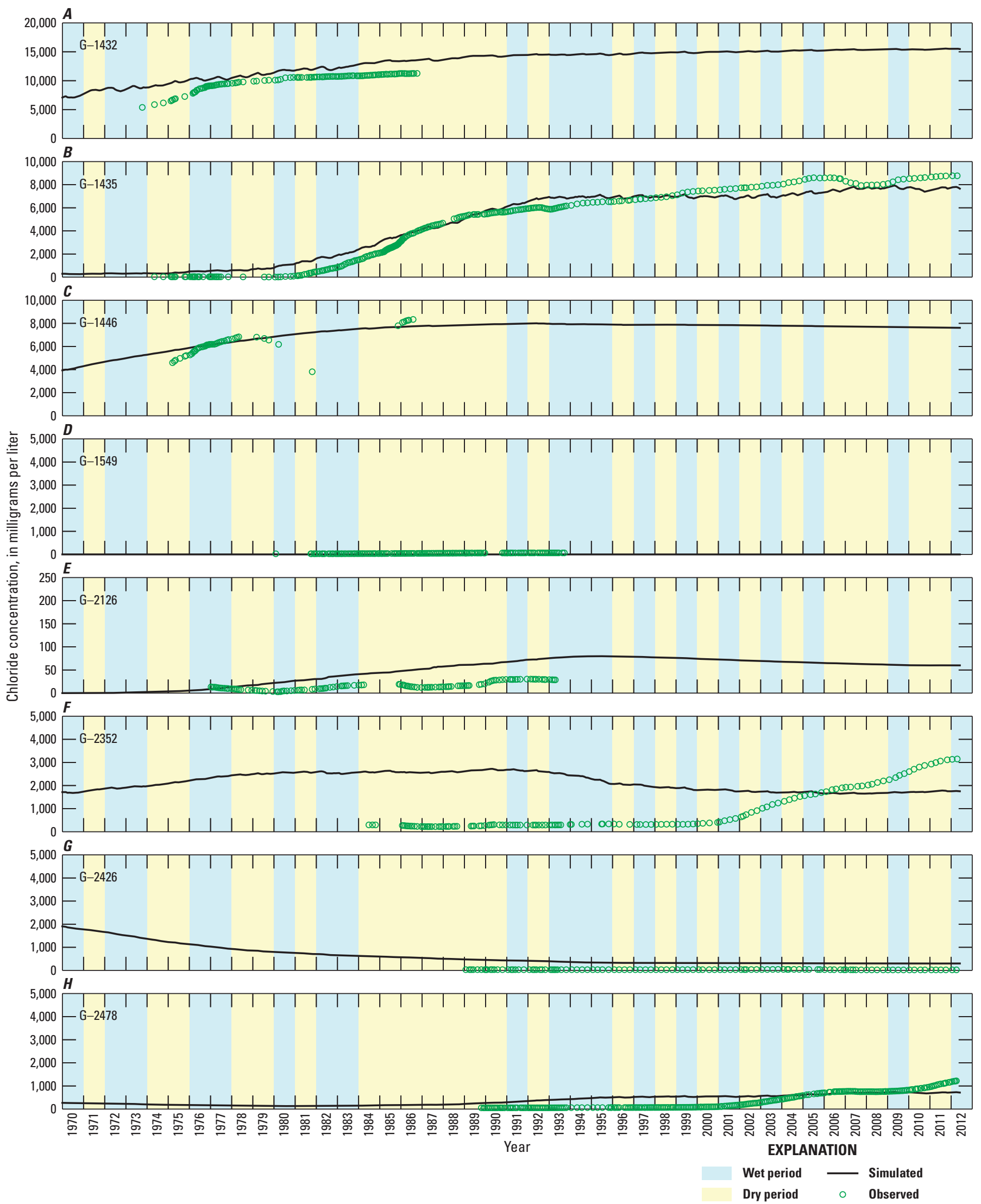

Figure 1-21. Simulated and observed chloride concentrations at the 11 observation locations. The location of the chloride observation locations are shown in figure 1-8. 


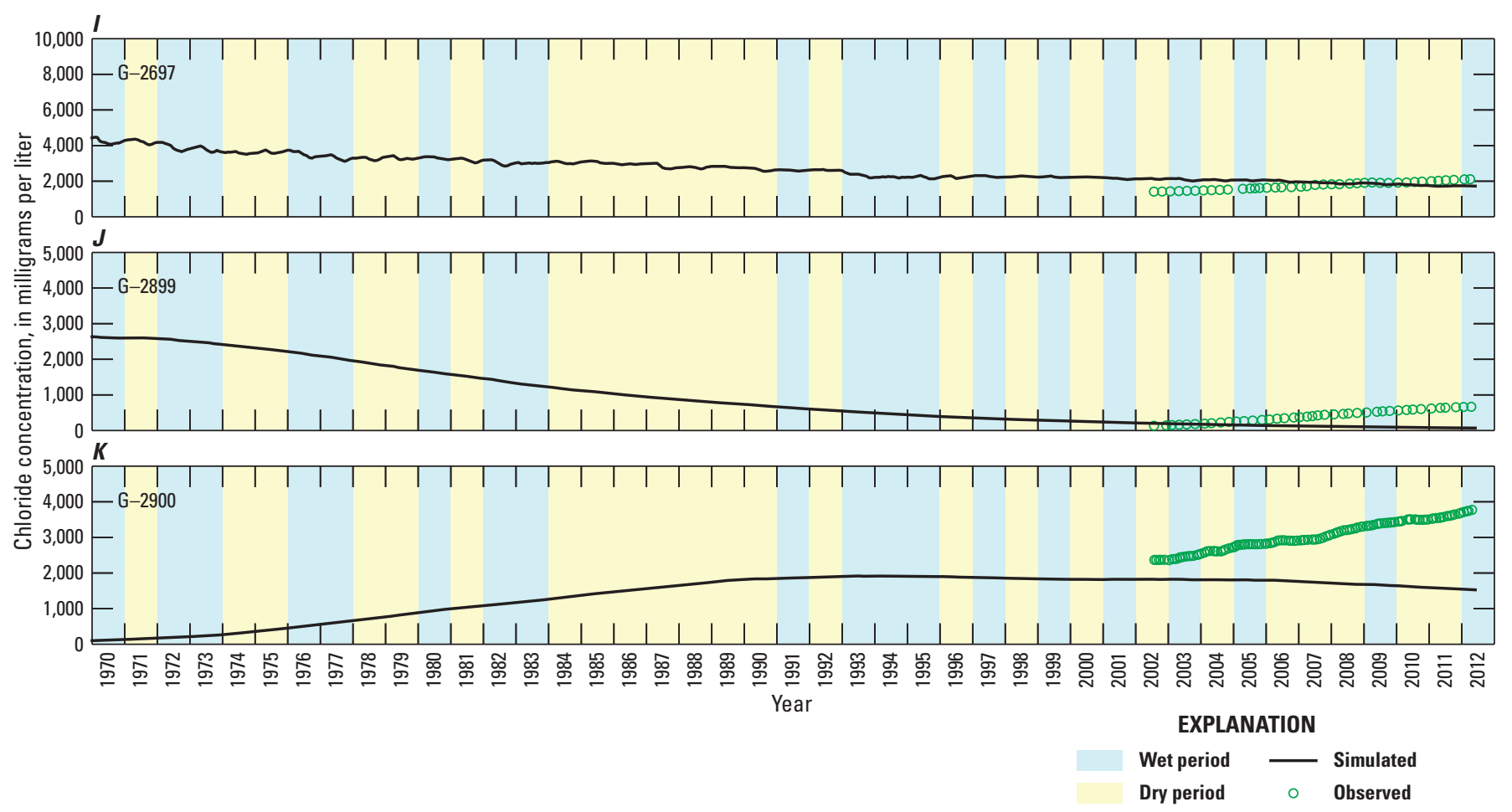

Figure 1-21. Simulated and observed chloride concentrations at the 11 observation locations. The location of the chloride observation locations are shown in figure 1-8.-Continued

\section{Groundwater Levels}

Error statistics were calculated for 5,752 pairs of simulated and observed monthly average groundwater levels at 15 sites during the calibration period. Simulated and observed groundwater levels at the 15 groundwater observation sites are shown in figure 1-22. During the calibration period, the global overall model ME and RMSE were 0.19 and $2.12 \mathrm{ft}$, respectively. The RMSE is approximately 7 percent of the total range of groundwater heads observed in the active model domain and represents a reasonable error. The small positive value for the overall ME indicates that the model is simulating groundwater levels that are slightly higher, on average, than observed values. Figure 1-22 shows generally a good qualitative match between simulated and observed water levels at most sites. Simulated water levels tend to be overestimated at wells G-617, G-1220, G-1473, and G-2900. Simulated water levels tend to be underestimated at well G-2395. Poorer matches are probably a consequence of the model adjusting parameters to match water levels and salinities simultaneously.

Simulated water-table elevations at the end of 2011 range from approximately $6 \mathrm{ft}$ at the western edge of the active model to less than $0 \mathrm{ft}$ at the coast (fig. 1-23). The position of the 0 -ft contour is largely controlled by the salinity control structures. Water levels are highest in the northwestern part of the active part of the model. Water levels are also relatively high in the C-9 West surface-water basin (location shown in fig. 1). Relatively high water levels in the northwestern and western parts of the C -9 surface-water basin are consistent with water levels adjacent to the water conservation areas, because surface water is impounded in these areas. 


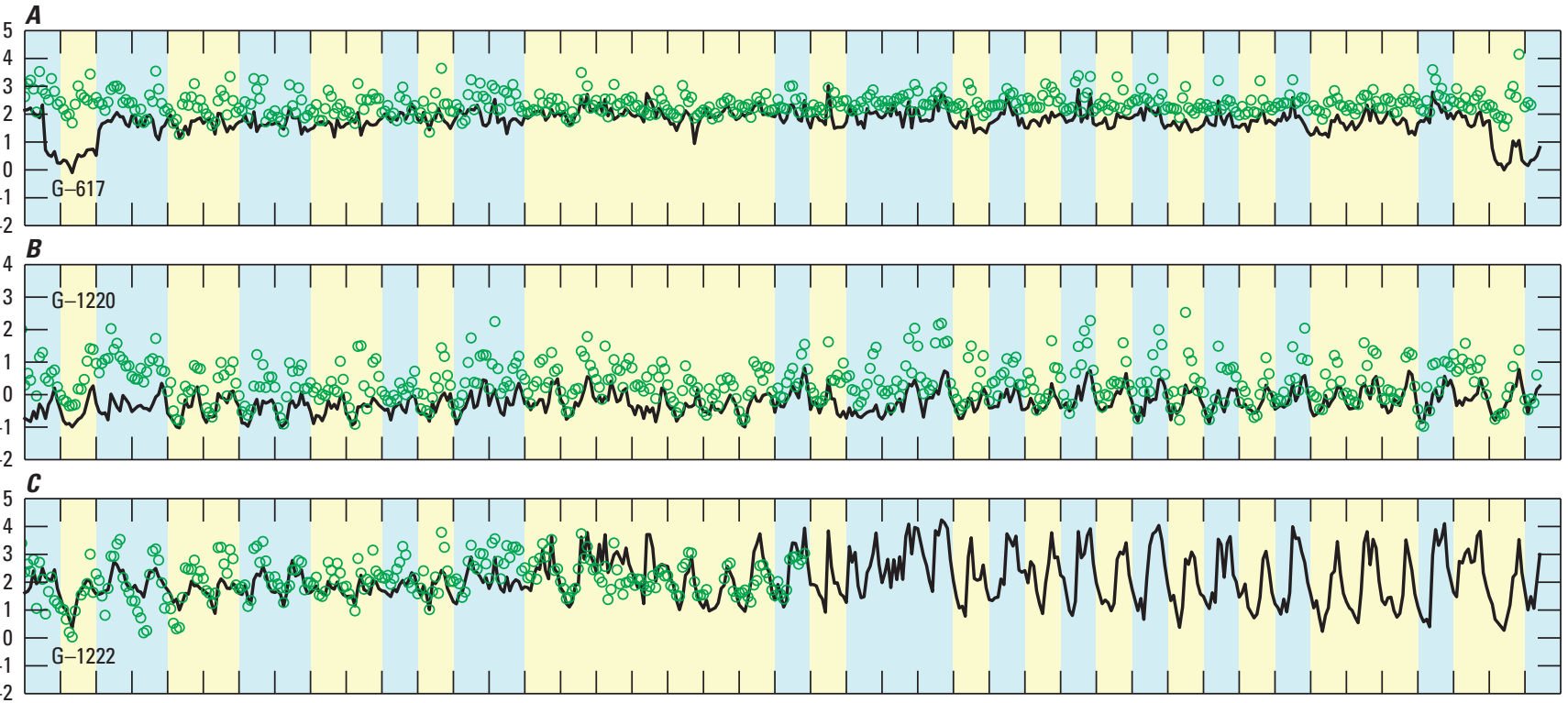

D

E

M a d M

5

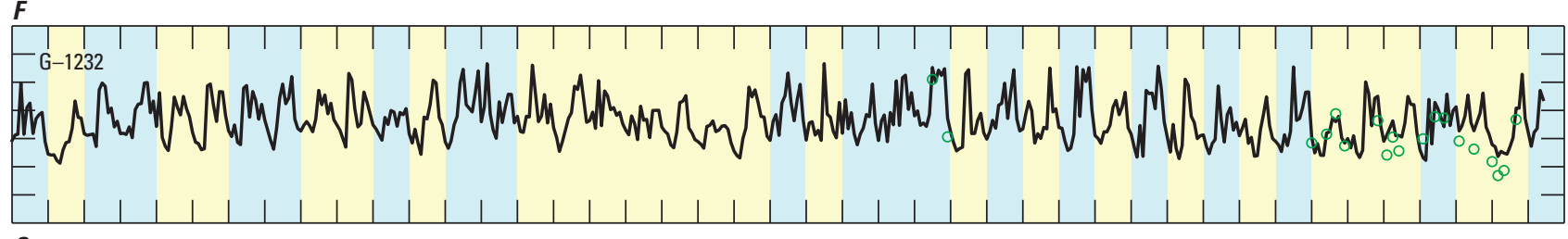

$10 \boldsymbol{G}$

\begin{tabular}{l}
8 \\
6 \\
4 \\
2 \\
\hline
\end{tabular} 2.5 H

2.5
2.0
1.5
1.0

0.5

0.0
-1.5
-1.5

$-1.5$

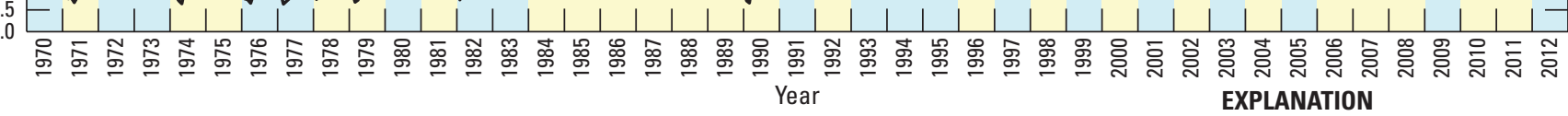

$\begin{array}{lll}\text { Wet period } & & \text { Simulated } \\ \text { Dry period } & \circ & \text { Observed }\end{array}$

Figure 1-22. Simulated and observed water levels at the 15 observation locations. The location of the water-level observation locations are shown in figure 1-8. 


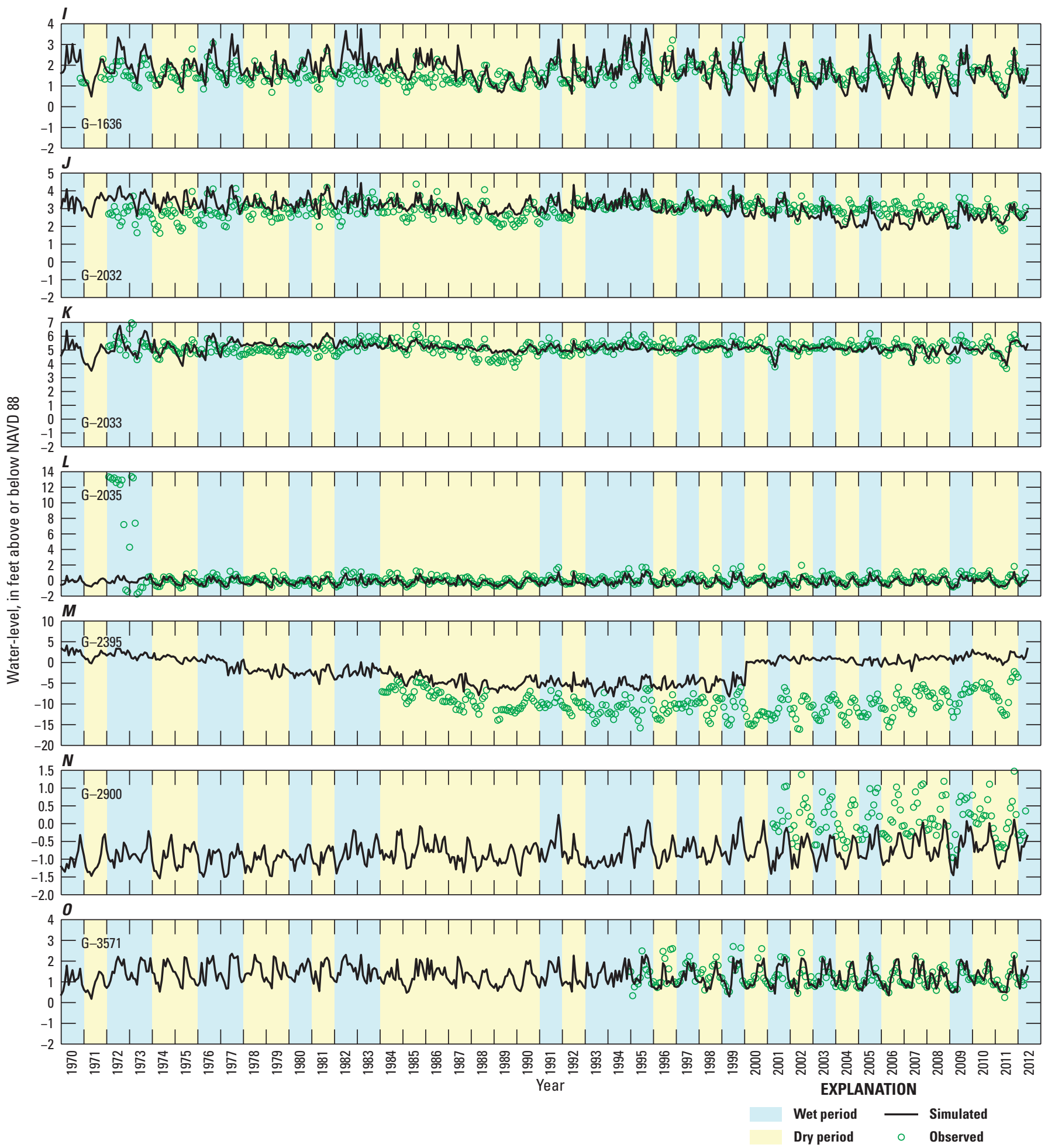

Figure 1-22. Simulated and observed water levels at the 15 observation locations. The location of the water-level observation locations are shown in figure 1-8.-Continued 


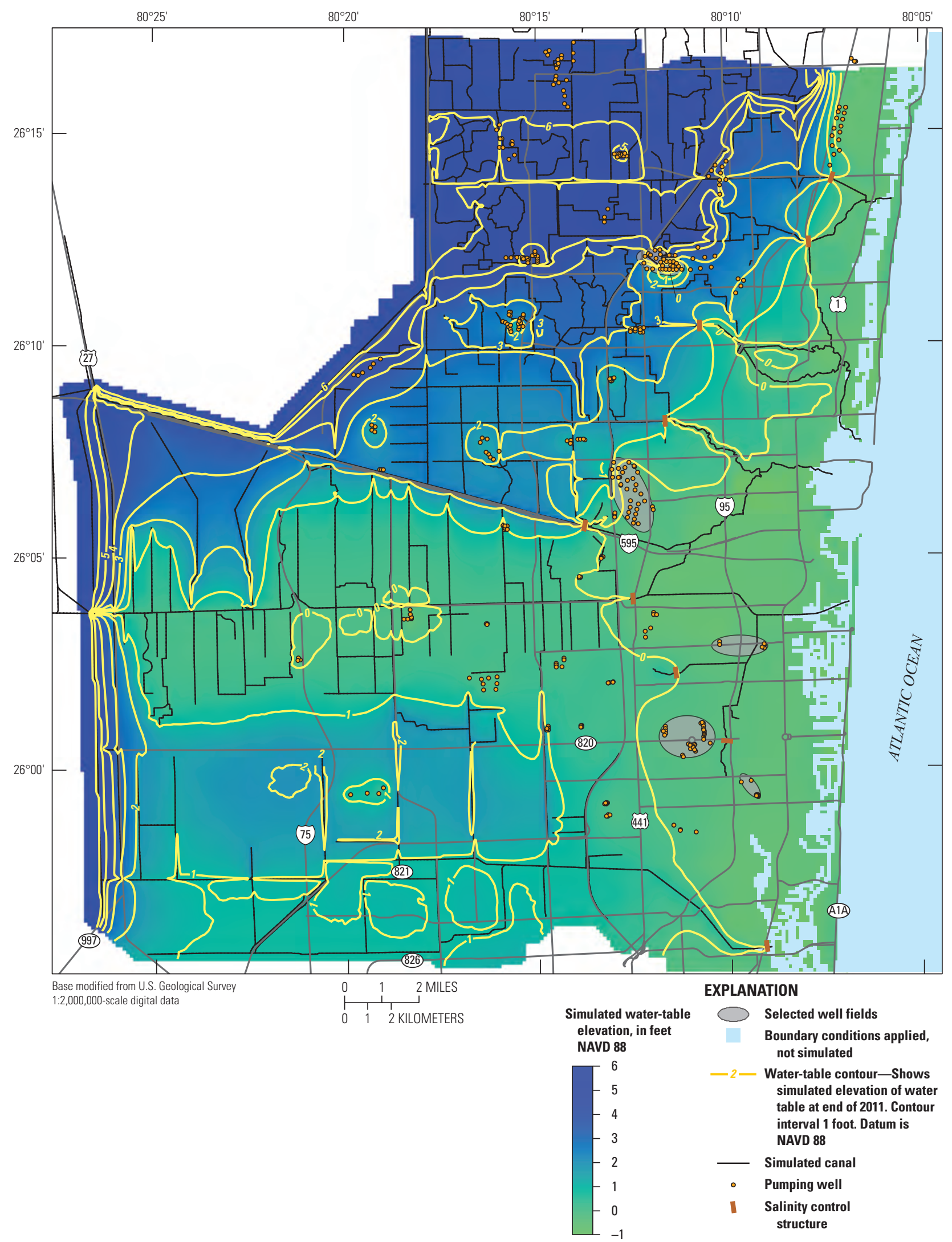

Figure 1-23. Simulated water-table elevations at the end of 2011 in the active part of the model. 


\section{Discussion}

Few published data exist to constrain the distribution of hydraulic properties of the Biscayne aquifer and underlying units in Broward County. Estimated hydraulic conductivity from field testing ranges over 4 orders of magnitude (Fish, 1988). Recent studies of the Biscayne aquifer in Miami-Dade County indicate different scales of porosity vertically within individual test wells in the Biscayne aquifer, and a highly variable distribution of porosity at the well-field scale (Wacker and others, 2014; Cunningham and others, 2006). The estimated distributions of hydraulic properties in this model are reflective of the large ranges of values and sparse spatial density of existing data. The blocky nature and heterogeneity of estimated parameter values (for example, figs. 1-14 through $1-17,1-20)$, are thus the result of the minimal constraints on the properties based on known distribution, the pilot point distribution, and the freedom of the model to use the calibration data to constrain the properties. Although intuition and observations of the hydrogeology of the Biscayne aquifer in Miami-Dade County would indicate variability of hydraulic properties on a much smaller scale in Broward County, data are not available to better inform or refine the model beyond its current state.

Some artifacts of the pilot point method should not be misconstrued as an interpretation of the true distribution of hydraulic properties (for example, fig. 1-15). Sharp transitions in hydraulic conductivity in the southwestern part of the model area are an artifact of interpolation and are present in regions where there are coarse pilot points and no fine pilot points. These artifacts are removed in the primary area of focus and are expected to have a minor effect on the simulated movement of the freshwater-saltwater interface.

The simulated distribution of salinity is strongly affected by the initial salinity conditions imposed. For this model, the initial salinity distribution was calibrated by starting with an estimated initial location and running successive simulations for undeveloped conditions to approach a steady-state distribution. The predevelopment distribution of salinity is unknown. Intuitively, salinity should generally increase during the historical simulation period as pumping and sea level gradually increase. In some cases, however, such as at G-2426, G-2697, and G-2899, the simulated historical trends are inverted from what would be expected. It is possible that predevelopment conditions in some parts of the simulated area are not close to steady-state conditions.

\section{Model Sensitivity}

Model calibration was completed with PEST using highly parameterized inversion techniques. During the calibration process, the observation processing methodology was refined several times to increase parameter sensitivity to parts of the observation dataset that most resemble the predictions of interest and to improve the ability of the model to simulate the effect of groundwater withdrawals and sea-level rise on movement of the freshwater-saltwater interface. Furthermore, insensitive parameter components and observation components that did not provide any information about parameter values were automatically excluded from the calibration process because these components are, by definition, contained wholly within the null subspace of the forward model operator; null subspace components are not adjusted when the truncated singular value decomposition algorithm is used (Doherty, 2010).

Composite parameter sensitivities, which are a measure of the information content of observations relative to a specific model parameter, are useful in identifying sensitive model parameters (Doherty, 2010). Furthermore, because composite parameter sensitivities are normalized, they can be used to compare the contribution of each parameter to minimizing the objective function during the automated parameter estimation process. The composite sensitivity $s$ of parameter $i$ is calculated using the equation

$$
S_{i}=\frac{\left(\mathbf{J}^{T} \mathbf{w}^{2} \mathbf{J}\right)_{i i}^{1 / 2}}{m}
$$

where

$$
\begin{gathered}
\text { J is the Jacobian (sensitivity) matrix, } \\
T \text { is the matrix transpose operation, } \\
\mathbf{w} \text { is the diagonal matrix of observation } \\
m \text { weights, and } \\
\text { is the number of observations with } \\
\text { nonzero weights. }
\end{gathered}
$$

Composite parameter sensitivities were calculated for the 1,842 parameters (the sum of all single parameters and parameters distributed using pilot points) estimated during model calibration. Frequency analyses of calculated composite parameter sensitivities for parameters grouped by (1) parameter type (for example, hydraulic conductivity) and (2) parameter unit (where appropriate) indicated that the calculated composite parameter sensitivities can vary substantially in a group and between groups (fig. 1-24). In general, the majority of composite parameter sensitivities are clustered in adjacent bins with the exception of recharge multipliers.

The most sensitive parameters are the initial interface elevation multipliers, recharge multipliers, reference evapotranspiration multipliers, and extinction depth multipliers; these parameters have high sensitivities because they directly affect net groundwater recharge and initial fractional seawater concentrations used in the model. Recharge multipliers are not as sensitive during the dry season (November-April) because of relatively low rainfall rates during those months. Porosity is also a sensitive parameter in the active transport domain (fig. 1-1), but not as sensitive in the inactive transport domain (PRD unit) or for pilot points that are not located near waterquality observation wells or selected well fields (Broward 1A, 

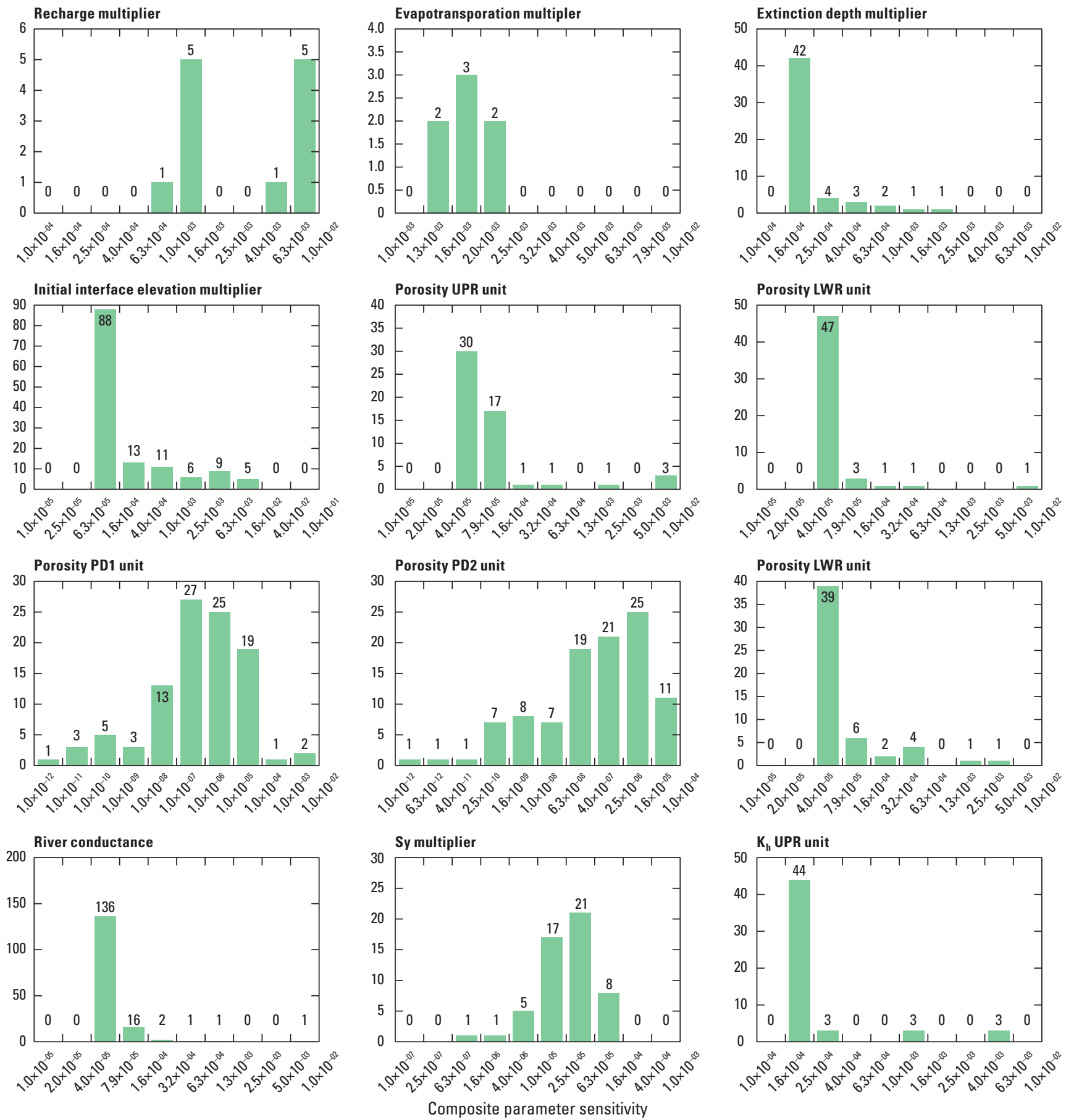

Figure 1-24. Composite parameter sensitivity of simulated groundwater levels, salinities at calibration points, and flowweighted well-field chloride concentrations to parameter changes. Composite parameter sensitivities are used to show relative parameter sensitivity; the definition and derivation are presented in Doherty (2010). 

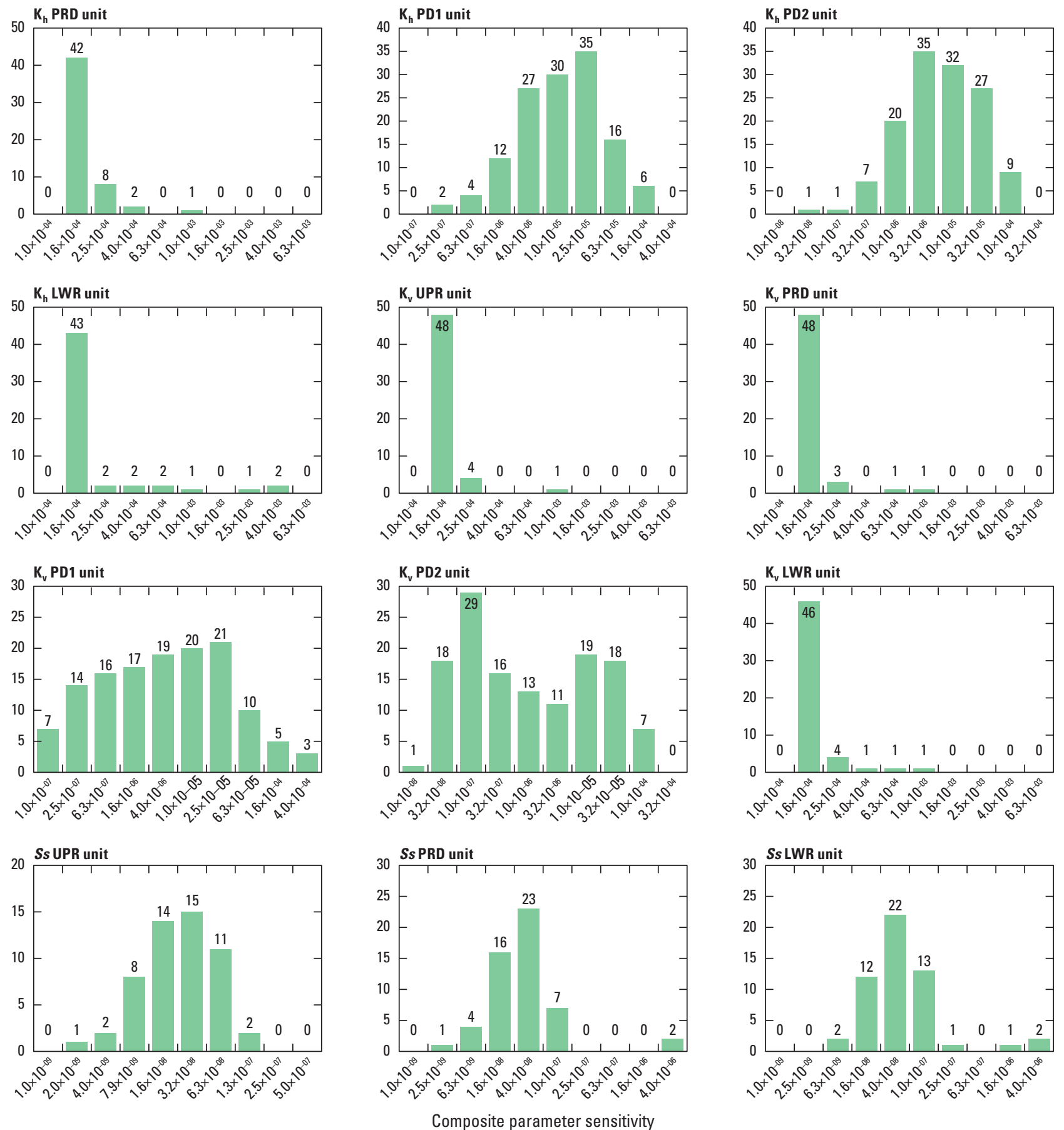

Figure 1-24. Composite parameter sensitivity of simulated groundwater levels, salinities at calibration points, and flowweighted well-field chloride concentrations to parameter changes. Composite parameter sensitivities are used to show relative parameter sensitivity; the definition and derivation are presented in Doherty (2010)._Continued 
Broward 3A, Broward 3B, Executive Airport, Prospect, Dixie, Dania, Hollywood, and Hallandale well fields). The model is sensitive to porosity values near observation locations because porosity is used to calculate groundwater velocities. A total of 64 porosity pilot points in the PD1 and PD2 units had a composite parameter sensitivity of zero as a result of their distance from observation locations. Although one river conductance parameter was very sensitive, the remaining 156 conductance parameters were only moderately sensitive. All of the horizontal and vertical hydraulic conductivity parameters were moderately sensitive, which is a result of the effect of these parameters on groundwater flow. Specific storage typically affects groundwater levels in highly permeable aquifers, such as the Biscayne aquifer, on short time scales. Use of monthly time steps in the model is the probable reason for the low sensitivity of specific storage parameters.

Traditionally, sensitivity analyses have been used to quantify the uncertainty of a calibrated model resulting from uncertainty in estimated model parameters, stresses, and boundary conditions (Anderson and Woessner, 1992). The calculated composite parameter sensitivities demonstrate that some of the parameters included in the calibration process are well informed by the processed observation dataset and that sensitivity to this dataset has been distributed among many parameters.

It is not uncommon to infer that the uncertainty of model predictions is reduced if model parameters are estimated as part of a minimum-error-variance estimation process, such as the process implemented with PEST in this study. Without considering prior probabilities in a Bayesian context and evaluation of specific model predictions, however, the actual model prediction uncertainty cannot be quantified (Doherty and others, 2010b; Fienen and others, 2010). Formal uncertainty quantification, using linear or nonlinear subspace methods or true Bayesian methods, would be required to quantify the uncertainty of specific predictions made using the model developed in this study.

The uncertainty associated with the specific scenarios evaluated using the model developed in this study, and other similar scenarios, has not been formally quantified. As a result, model projection uncertainties must be inferred from the calculated composite parameter sensitivities. Based on (1) calculated composite parameter sensitivities, and (2) minimization of the objective function using PEST, it is expected that the model will be useful for evaluating groundwater levels and movement of the freshwater-saltwater interface, provided the model is applied at similar spatial and temporal scales under hydrologic conditions comparable to those observed during the calibration period.

\section{References}

Anderson, M.P., and Woessner, W.W., 1992, Applied groundwater modeling, simulation of flow and advective transport: San Diego, Calif., Academic Press, Inc., 381 p.

Aster, R.C., Borchers, B., and Thurber, C.H., 2005, Parameter estimation and inverse problems: Amsterdam, Elsevier Academic Press, 301 p.

Brakefield, L., Hughes, J.D., Langevin, C.D., and Chartier, K., 2013, Estimation of capture zones and drawdown at the Northwest and West Well Fields, Miami-Dade County, Florida, using an unconstrained Monte Carlo analysis: recent (2004) and proposed conditions: U.S. Geological Survey Open-File Report: 2013-1086, 124 p, accessed May, 19, 2014, at available online at http://pubs.usgs.gov/ of/2013/1086.

Camp Dresser and McKee and DHI Water and Environment, 2002, Modeling water management practices in Central Broward County, Florida, Phase 2, Numerical model building and modeling results: Consultant's report prepared for Broward County.

Cunningham, K.J., Wacker, M.A., Robinson, Edward, Dixon, J.F., and Wingard, G.L., 2006, A cyclostratigraphic and borehole-geophysical approach to development of a threedimensional conceptual hydrogeologic model of the karstic Biscayne aquifer, southeastern Florida: U.S. Geological Survey Scientific Investigations Report 2005-5235, 69 p., plus CD-ROM.

Deutsch, C.V., and Journel, A.G., 1998, GSLIB - Geostatistical software library: Oxford University Press, 384 p.

DHI Water and Environment and Camp Dresser and McKee, 2005, Task 4.2 South Area Drainage Assessment MIKE SHE model report-Broward County, Florida: Consultant's report prepared for Broward County, $173 \mathrm{p}$.

Doherty, J.E., 2010, PEST, Model-independent parameter estimation-User manual (5th ed.): Brisbane Australia, Watermark Numerical Computing.

Doherty, J.E., Fienen, M.F., and Hunt, R.J., 2010a, Approaches to highly parameterized inversion-Pilot point theory, guidelines and research directions: U.S. Geological Survey Scientific Investigations Report 2010-5168, 36 p.

Doherty, J.E., and Hunt, R.J., 2010, Approaches to highly parameterized inversion-A guide to using PEST for groundwater model calibration: U.S. Geological Survey Scientific Investigations Report 2010-5169, 59 p.

Doherty, J.E., Hunt, R.J., and Tonkin, M.J., 2010b, Approaches to highly parameterized inversion-A guide to using PEST for model-parameter and predictive-uncertainty analysis: U.S. Geological Survey Scientific Investigations Report 2010-5211, 71 p. 
Doherty, J.E., and Welter, D.E., 2010, A short exploration of structural noise: Water Resources Research, v. 46, W05525.

Doherty, John, 2003, Groundwater model calibration using pilot-points and regularization: Ground Water, v. 41, no. 2, p. 170-177. [Also available at http://dx.doi.org/ 10.1111/j.1745-6584.2003.tb02580.x.]

Fienen, M.N., Doherty, J.E., Hunt, R.J., and Reeves, H.W., 2010, Using prediction uncertainty analysis to design hydrologic monitoring networks-Example applications from the Great Lakes water availability pilot project: U.S. Geological Survey Scientific Investigations Report 2010-5159, 44 p.

Fish, J.E., 1988, Hydrogeology, aquifer characteristics, and ground-water flow of the surficial aquifer system, Broward County, Florida: U.S. Geological Survey Water-Resources Investigations Report 87-4034, 92 p.

Florida Division of Emergency Management, 2007, Broward County LiDAR data: Florida Division of Emergency Management, accessed October 1, 2014, at http://www.floridadisaster.org/gis/LiDAR/.

Giddings, J.B., Kuebler, L.L., Restrepo, J.I., Rodberg, K.A., Montoya, A.M., and Radin, H.A., 2006, Draft report of Lower East Coast subRegional (LECsR) MODFLOW model documentation: South Florida Water Management District, 294 p.

Guo, Weixing, and Langevin, C.D., 2002, User's guide to SEAWAT: A computer program for simulation of threedimensional variable-density ground-water flow: U.S. Geological Survey Techniques of Water-Resources Investigations, book 6, chap. A7, $77 \mathrm{p}$.

Harbaugh, A.W., Banta, E.R., Hill, M.C., and McDonald, M.G., 2000, MODFLOW-2000, the U.S. Geological Survey modular ground-water model - User guide to modularization concepts and the Ground-Water Flow Process: U.S. Geological Survey Open-File Report 00-92, 121 p.

Hughes, J.D., Sifuentes, D.F., and White, J.T., 2016, SEAWAT model used to evaluate the potential effects of alterations to the hydrologic system on the distribution of salinity in the Biscayne aquifer in Broward County, Florida: U.S. Geological Survey data release, http://dx.doi.org/10.5066/F7PV6HFR.

Isaaks, E.H., and Srivastava, R.M., 1989, An introduction to applied geostatistics: New York, Oxford University Press, 561 p.

Jacobs J.M., Mecikalski, J.R., and Paech, S.J., 2008, Satellitebased solar radiation, net radiation, and potential and reference evapotranspiration estimates over Florida: Report prepared for the U.S. Geological Survey, 138 p., accessed March 12, 2013, at http://fl.water.usgs.gov/et/publications/ GOES_FinalReport.pdf.

Langevin, C.D., 2001, Simulation of ground-water discharge to Biscayne Bay, southeastern Florida: U.S. Geological Survey Water-Resources Investigations Report 00-4251, 127 p., 3 pls.
Langevin, C.D., and Guo, W., 2006, MODFLOW/MT3DMSbased simulation of variable density ground water flow and transport: Ground Water, v. 44, no. 3, p. 339-351.

Langevin, C.D., Shoemaker, W.B., and Guo, Weixing, 2003, MODFLOW-2000, the U.S. Geological Survey modular ground-water model-Documentation of the SEAWAT-2000 version with the Variable-Density Flow Process (VDF) and the Integrated MT3DMS Transport Process (IMT): U.S. Geological Survey Open-File Report 03-426, 43 p.

Langevin, C.D., Thorne, D.T., Jr., Dausman, A.M., Sukop, M.C., and Guo, Weixing, 2007, SEAWAT Version 4-A computer program for simulation of multi-species solute and heat transport: U.S. Geological Survey Techniques and Methods, book 6, chap. A22, 39 p.

Langevin, C.D., and Zygnerski, M., 2013, Effect of sea-level rise on salt water intrusion near a coastal well field in southeastern Florida: Groundwater, v. 51, no. 5, p. 781-803. [Also available at http://onlinelibrary.wiley.com/doi/ 10.1111/j.1745-6584.2012.01008.x/full.]

Marella, R.L., 1988, Water withdrawals, use, and trends in Florida, 1985: U.S. Geological Survey Water-Resources Investigations Report 88-4103, 43 p.

Marella, R.L., 1992, Water withdrawals, use, and trends in Florida, 1990: U.S. Geological Survey Water-Resources Investigations Report 92-4140, $38 \mathrm{p}$.

Marella, R.L., 1995, Water-use data by category, and water management district in Florida, 1950-90: U.S. Geological Survey Open-File Report 94-521, 114 p.

Marella, R.L., 1999, Water withdrawals, use, discharge and trends in Florida, 1995: U.S. Geological Survey WaterResources Investigations Report 99-4002, 90 p.

Marella, R.L., 2004, Water withdrawals, use, discharge, and trends in Florida, 2000: U.S. Geological Survey Scientific Investigations Report 2004-5151, 50 p., plus app.

Marella, R.L., 2009, Water withdrawals, use, and trends in Florida, 2005: U.S. Geological Survey Scientific Investigations Report 2009-5125, 49 p.

Marella, R.L., 2014, Water withdrawals, use, and trends in Florida, 2010: U.S. Geological Survey Scientific Investigations Report 2014-5088, 59 p. [Also available at http://dx.doi.org/10.3133/sir20145088.]

Marquardt, Donald, 1963, An algorithm for least-squares estimation of nonlinear parameters: SIAM Journal on Applied Mathematics, v. 11, no. 2, p. 431-441.

Merritt, M.L., 1996, Assessment of saltwater intrusion in southern coastal Broward County, Florida: U.S. Geological Survey Water-Resources Investigations Report 96-4221, 133 p.

Moore, C.A., and Doherty, J.E., 2005, The role of the calibration process in reducing model predictive error: Water Resources Research, v. 41, no. 5, W05020. 
National Oceanic and Atmospheric Administration, 2012, Tides and Currents-Historic Water Levels Database: Accessed October 2012, at http://tidesandcurrents.noaa.gov/ stations.html?type=Historic+Water+Levels\#Florida.

Neary, V.S., Habib, E.H., and Fleming, M.J., 2004, Hydrologic modeling with NEXRAD precipitation in middle Tennessee: Journal of Hydrologic Engineering, v. 9, no. 5, p. 339-349. [Also available at http://dx.doi.org/10.1061/(ASCE)10840699(2004)9:5(339).]

Oliver, D.S., Reynolds, A.C., and Liu, Ning, 2008, Inverse theory for petroleum reservoir characterization and history matching: Cambridge University Press.

Pearlstine, Leonard, Higer, Aaron, Palaseanu, Monica, Fujisaki, Ikuko, and Mazzotti, Frank, 2007, Spatially continuous interpolation of water stage and water depths using the Everglades Depth Estimation Network (EDEN): Gainesville, Fla., Institute of Food and Agriculture, University of Florida, CIR 1521, 18 p., 2 apps., accessed June 17, 2013, at http://edis.ifas.ufl.edu/pdffiles/UW/ UW27800.pdf.

Perkins, R.D., 1977, Depositional framework of Pleistocene rocks in south Florida, in Enos, Paul, and Perkins, R.D., eds., Quaternary sedimentation in south Florida: Geological Society of America Memoir 147, p. 131-198.

Press, W.H., Teukolsky, S.A., Vetterling, W.T., and Flannery, B.P., 1990, Numerical recipes in C: New York, Cambridge University Press, 994 p.

Reese, R.S., and Cunningham, K.J., 2000, Hydrogeology of the gray limestone aquifer in southern Florida: U.S. Geological Survey Water-Resources Investigations Report 99-4213, 244 p.

Remy, Nicolas, Boucher, Alexandre, and Wu, Jianbing, 2009, Applied geostatistics with SGeMS - A user's guide: Cambridge University Press, 286 p.

Renken, R.A., Cunningham, K.J., Shapiro, A.M., Harvey, R.W., Zygnerski, M.R., Metge, D.W., and Wacker, M.A., 2008, Pathogen and chemical transport in the karst limestone of the Biscayne aquifer: 1. Revised conceptualization of groundwater flow: Water Resources Research, v. 44, p.

Renken, R.A., Dixon, Joann, Koehmstedt, John, Lietz, A.C., Marella, R.L., Telis, Pamela, Rodgers, Jeff, and Memberg, Steven, 2005, Impact of anthropogenic development on coastal ground-water hydrology in southeastern Florida, 1900-2000: U.S. Geological Survey Circular 1275, 77 p.

Skinner, Courtney, Bloetscher, Fredrick, and Pathak, C.S., 2009, Comparison of NEXRAD and rain gauge precipitation measurements in South Florida: Journal of Hydrologic Engineering, v. 14, no. 3, p. 248-260. [Also available at http://dx.doi.org/10.1061/(ASCE)1084-0699(2009)14:3(248).]
South Florida Water Management District, 2005, Documentation of the South Florida Water Management ModelVersion 5.5: South Florida Water Management District, 305 p., accessed March 13, 2013, at http:/www.sfwmd. gov/portal/page/portal/xrepository/sfwmd_repository_pdf/ sfwmm_final_121605.pdf.

Telis, P.A., 2006, The Everglades Depth Estimation Network (EDEN) for support of ecological and biological assessments: U.S. Geological Survey Fact Sheet 2006-3087, 4 p.

Tikhonov, A.N., and Arsenin, V.Y., 1977, Solutions of illposed problems: New York, Halstead Press-Wiley, 258 p.

Tonkin, M.J., and Doherty, J.E., 2005, A hybrid regularized inversion methodology for highly parameterized models: Water Resources Research, v. 29. [Also available at http://dx.doi.org/10.1029/2005WR003995.]

U.S. Geological Survey, 2012, National Water Information System data available on the World Wide Web (USGS Water Data for the Nation): Accessed June 10, 2012, at http://waterdata.usgs.gov/nwis/.

U.S. Geological Survey, 2014, National Water Information System data available on the World Wide Web (USGS Water Data for the Nation): Accessed February 7, 2014, at http://waterdata.usgs.gov/nwis/.

Vogel, C.R., 2002, Computational methods for inverse problems: Frontiers in Applied Mathematics, SIAM.

Wacker, M.A., Cunningham, K.J., and Williams, J.H., 2014, Geologic and hydrogeologic frameworks of the Biscayne aquifer in central Miami-Dade County, Florida: U.S. Geological Survey Scientific Investigations Report 2014-5138, 66 p. [Also available at http://dx.doi. org/10.3133/sir20145138.]

Wang, Xianwei, Xie, Hongjie, Sharif, Hatim, and Zeitler, Jon, 2007, Validating NEXRAD MPE and Stage III precipitation products for uniform rainfall on the Upper Guadalupe River Basin of the Texas Hill Country: Journal of Hydrology, v. 348, no. 1-2, p. 73-86. [Also available at http://dx.doi. org/10.1016/j.jhydrol.2007.09.057.]

Watkins, D.W., Li, Hebi, and Cowden, J.R., 2007, Adjustment of radar-based precipitation estimates for Great Lakes hydrologic modeling: Journal of Hydrologic Engineering, v. 12, no. 3, p. 298-305. [Also available at http://dx.doi. org/10.1061/(ASCE)1084-0699(2007)12:3(298).]

Zheng, C., 2006, MT3DMS v5.2 Supplemental user's guide: Technical Report to the U.S. Army Engineer Research and Development Center, Department of Geological Sciences, University of Alabama.

Zheng, C., and Wang, P.P., 1999, MT3DMS, A modular three-dimensional multi-species transport model for simulation of advection, dispersion and chemical reactions of contaminants in ground-water systems; documentation and user's guide: Vicksburg, Mississippi: U.S. Army Engineer Research and Development Center, Contract Report SERDP-99-1. 
Manuscript approved on February 4, 2016

Prepared by the USGS Science Publishing Network Raleigh Publishing Service Center

Edited by Michael Deacon

Illustrations Kimberly A. Swidarski

Layout by Caryl J. Wipperfurth

For more information about this publication contact: Director, USGS Caribbean-Florida Water Science Center U.S. Geological Survey 4446 Pet Lane, Suite 108

Lutz, FL 33559

http://fl.water.usgs.gov/ 
